\title{
Union democracy and the challenge of globalisation to organised labour in Ghana
}

Citation for published version (APA):

Britwum Ankrah, A. O. (2010). Union democracy and the challenge of globalisation to organised labour in Ghana. [Doctoral Thesis, Maastricht University]. Universitaire Pers Maastricht. https://doi.org/10.26481/dis.20100910ab

Document status and date:

Published: 01/01/2010

DOI:

10.26481/dis.20100910ab

Document Version:

Publisher's PDF, also known as Version of record

\section{Please check the document version of this publication:}

- A submitted manuscript is the version of the article upon submission and before peer-review. There can be important differences between the submitted version and the official published version of record.

People interested in the research are advised to contact the author for the final version of the publication, or visit the DOI to the publisher's website.

- The final author version and the galley proof are versions of the publication after peer review.

- The final published version features the final layout of the paper including the volume, issue and page numbers.

Link to publication

\footnotetext{
General rights rights.

- You may freely distribute the URL identifying the publication in the public portal. please follow below link for the End User Agreement:

www.umlib.nl/taverne-license

Take down policy

If you believe that this document breaches copyright please contact us at:

repository@maastrichtuniversity.nl

providing details and we will investigate your claim.
}

Copyright and moral rights for the publications made accessible in the public portal are retained by the authors and/or other copyright owners and it is a condition of accessing publications that users recognise and abide by the legal requirements associated with these

- Users may download and print one copy of any publication from the public portal for the purpose of private study or research.

- You may not further distribute the material or use it for any profit-making activity or commercial gain

If the publication is distributed under the terms of Article $25 \mathrm{fa}$ of the Dutch Copyright Act, indicated by the "Taverne" license above, 


\section{UNION DEMOCRACY AND THE CHALLENGE OF GLOBALISATION TO ORGANISED LABOUR IN GHANA}

Akua Opokua Britwum 
Cover graphic: (C) Naa Norkor Nartey (Knork Studios)

(C) Copyright: 2010, Akua O Britwum

ISBN 9789052789712 


\title{
UNION DEMOCRACY AND THE CHALLENGE OF GLOBALISATION TO ORGANISED LABOUR IN GHANA
}

\author{
DISSERTATION \\ to obtain the degree of Doctor at the Maastricht University, \\ on the authority of Rector Magnificus, \\ Prof. dr. G.P.M.F. Mols \\ in accordance with the decision of the Board of Deans, \\ to be defended in public \\ on Friday September 10 ${ }^{\text {th }}, 2010$ at 14:00 hours \\ by

\section{Akua Opokua Britwum}

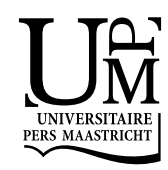




\section{Supervisors}

Prof. dr. Pim Martens

Prof. dr. Kwame A. Ninsin, Ghana

\section{Assessment Committee}

Prof. dr. Harro van Lente (Chairman)

Prof. dr. Joyeeta Gupta, VU University Amsterdam

Ass. Prof. dr. Stephen Kendie, University of Cape Coast, Ghana

Prof. dr. Valentina Mazzucato

This Ph.D. research was supported by the Ghana NUFFIC, 'MA Programme in Governance and Sustainable Development' project (NPT/GHA/042). 
'Political freedom and the rights of workers are indivisible, and therefore national development and workers' interests were inseparable.' ${ }^{1}$ 



\section{CONTENTS}

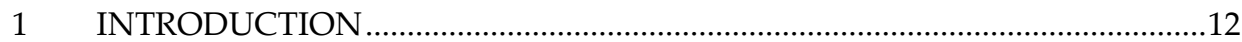

1.1 Background .............................................................................................12

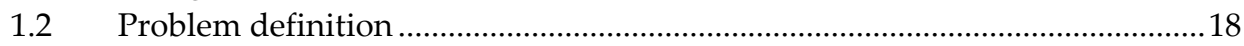

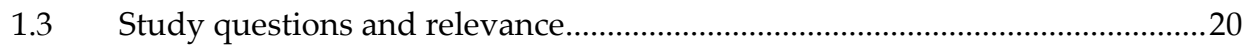

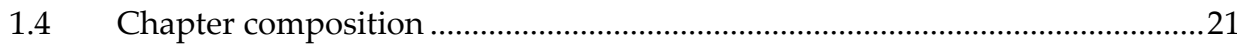

2 THE CONTOURS OF UNION GOVERNANCE AND DEMOCRACY .............26

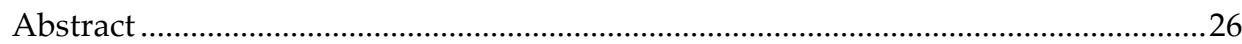

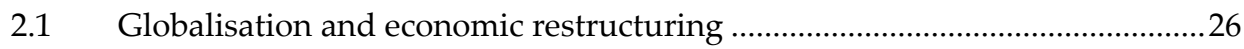

2.2 The nation-state under globalisation................................................................29

2.3 Restructuring the world of work and the shape of unionism...........................33

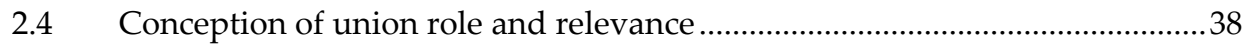

2.5 Organised labour responding to globalisation ………………...........................4

2.6 Collective organisation and interest representation.......................................47

2.7 Union renewal strategies and internal democracy-A conceptual

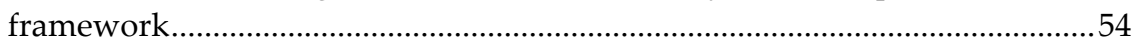

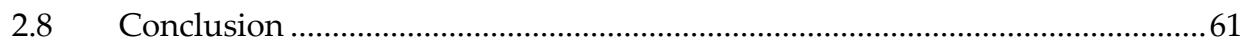

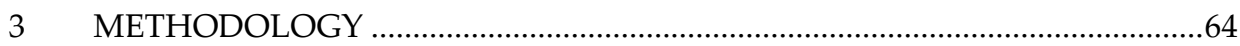

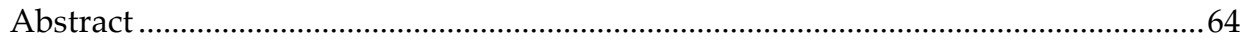

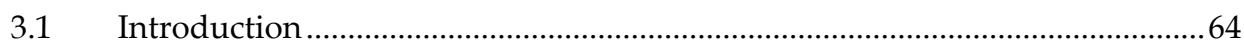

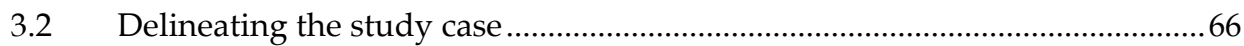

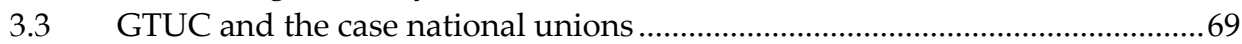

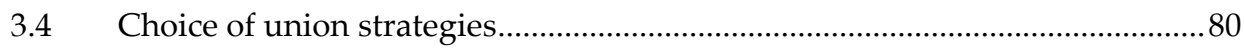

3.5 Data gathering procedure ..........................................................................8

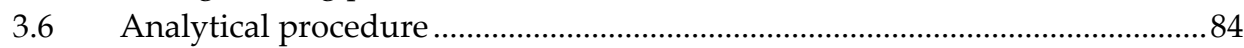

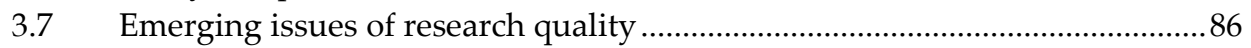

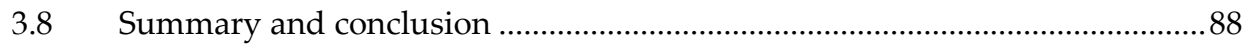

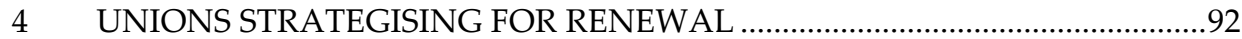

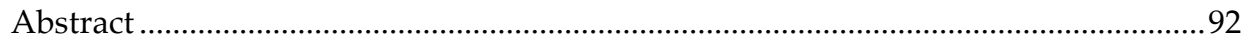

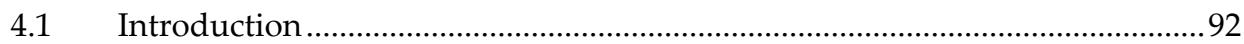

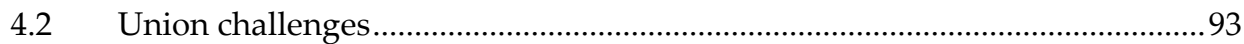

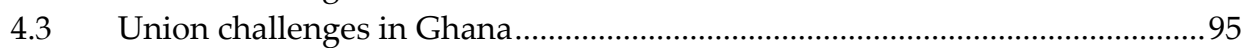

4.3.1 Privatisation and Work Restructuring ………………........................97

4.3.2 Labour Legislation.............................................................................. 104

4.3.3 Public Sector Reforms ....................................................................... 105

4.3.4 Perceived Utility of unions in the work place..........................................108

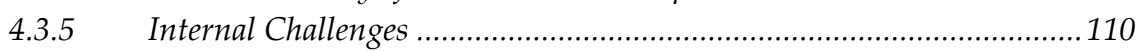




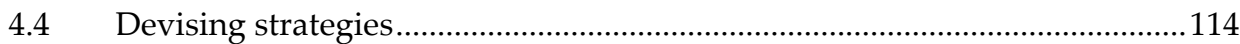

4.4.1 Organising: Expanding and retaining membership ............................116

4.4.2 Internal Restructuring .............................................................. 118

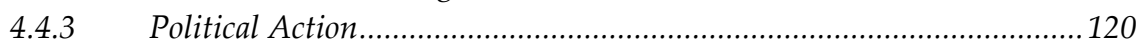

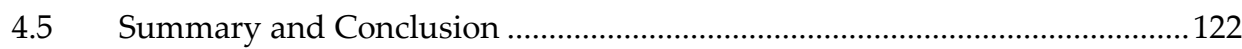

$5 \quad$ UNIONS IN THE INFORMAL ECONOMY ...................................................126

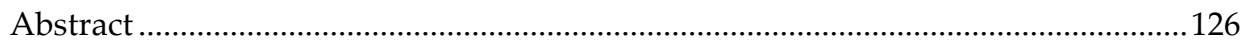

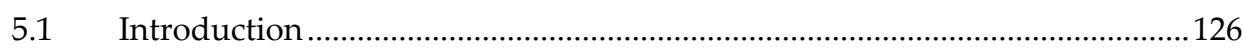

5.2 The formal and informal in national economies........................................... 128

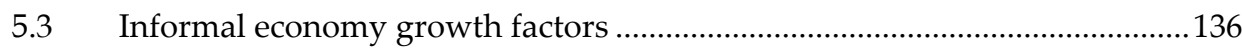

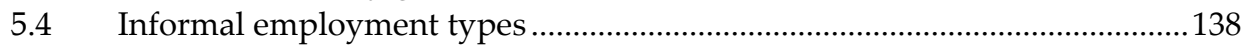

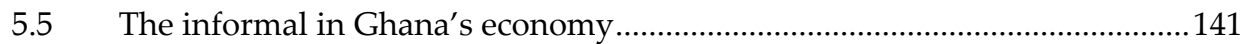

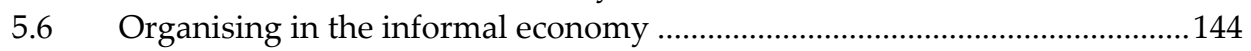

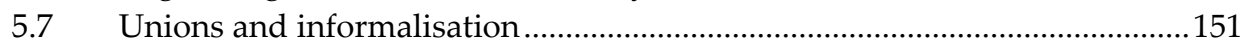

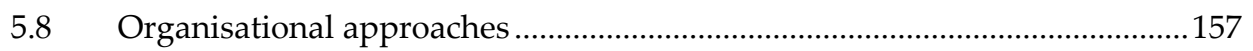

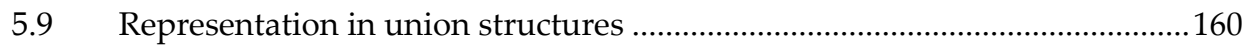

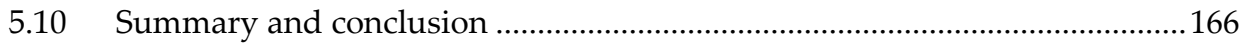

6 GENDER DEMOCRACY AND UNION REPRESENTATION IN GHANA..170

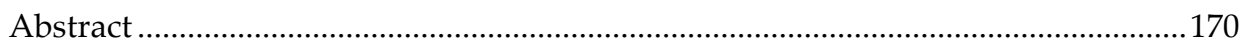

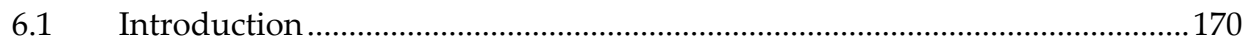

$6.2 \quad$ Unions negotiating class and patriarchy .................................................. 171

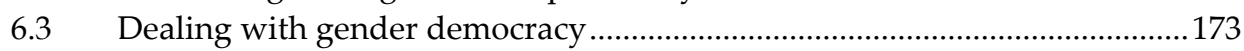

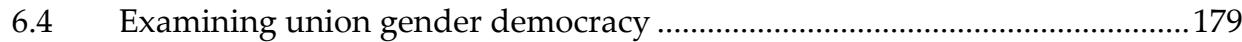

6.5 The female factor in the GTUC …............................................................... 182

6.6 Women's engagement with gender democracy in the GTUC .......................185

6.7 Barriers to women's trade union participation .............................................188

6.8 The women's committees and reserved seats ................................................... 194

6.9 Consciousness and the content of women's claims........................................199

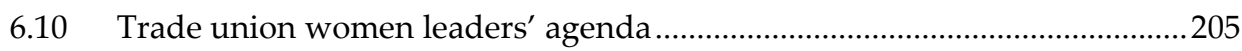

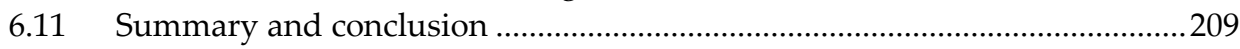

7 THE GTUC AND THE REGIONAL AND DISTRICT COUNCILS OF

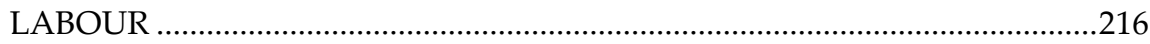

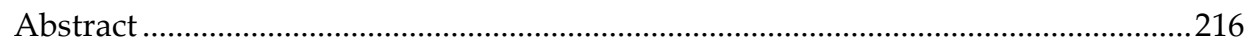

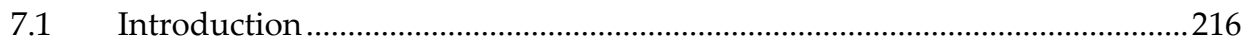

7.2 Exploring union internal democracy: issues arising ......................................219

7.3 Composition and institutional location of RCLs and DCLs..........................224

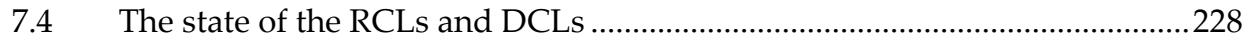

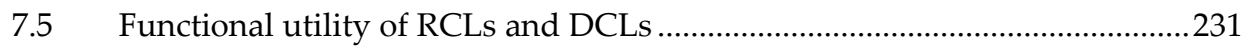

7.6 RCL and DCLs challenges, initiatives and achievements ..............................234

7.7 Demands for RCLs and DCL survival .........................................................239

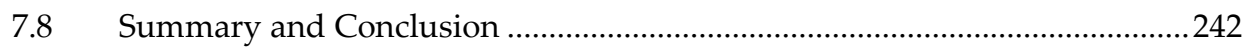


8 THE NATIONAL UNIONS AND THEIR MEMBERS ......................................246

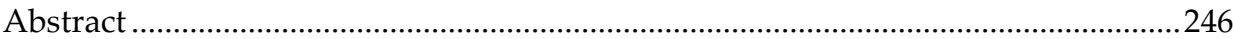

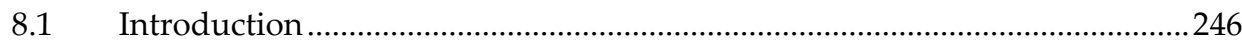

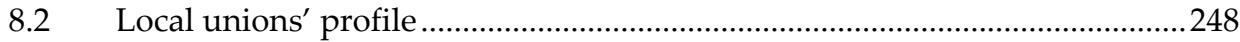

8.3 The functioning of local unions in the workplace .......................................250

8.3.1 The locals within union structures..................................................... 251

8.3.2 Local unions workplace functions .........................................................253

8.4 The content and target of workplace struggles.............................................257

8.4.1 Local union workplace struggles .......................................................258

8.4.2 Determinants of union future ............................................................265

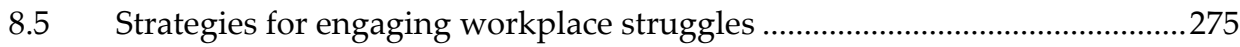

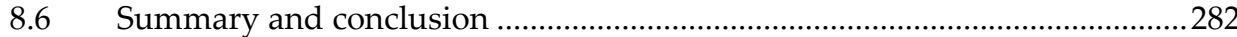

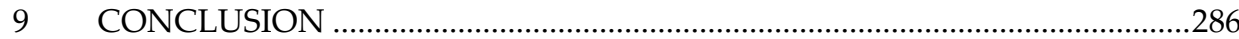

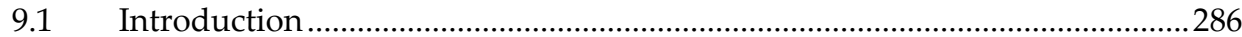

9.2 Exploring union renewal and internal democracy .........................................289

9.3 Union renewal and intra union power dynamics ...........................................291

9.4 Operational alterations of union functional terrain ........................................294

9.5 Internal power dynamism and effective union revitalisation........................296

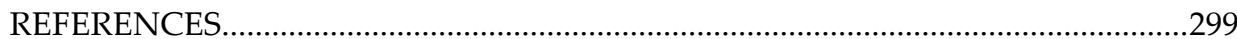

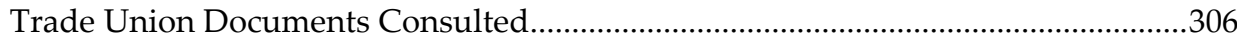

Appendix A: Research Participants - Individual Interviews ...................................309

Appendix B: Research Participants-Group Interviews ..........................................311

Appendix C: Research Participants -Union Events Covered ....................................314

Appendix D: National Union Affiliates of The GTUC …..........................................315

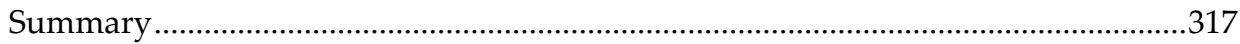

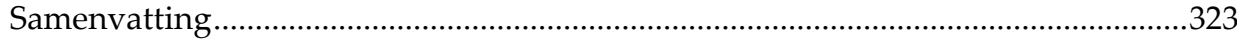

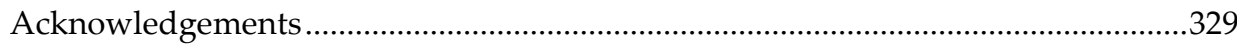

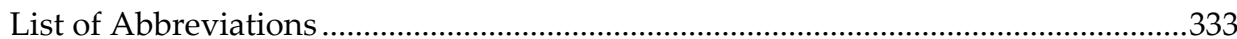

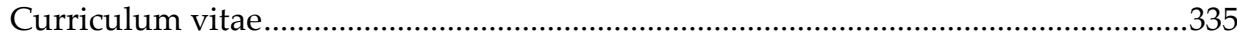



Chapter 1

INTRODUCTION 


\section{INTRODUCTION}

\subsection{BACKGROUND}

Trade Union is the accepted universal mode of organising adopted by working people to protect and improve on the conditions under which they operate under capitalism (Harrod \& O'Brien, 2002; Fairbrother, 1990). As collective organisations of working people, trade unions embody complex sets of relations deriving from their unique location between workers and their employers, workers and the nation state and also among the workers who constitute their members. Basically an institutional creation of capitalist production relations in the nineteenth century, trade unions have functioned to provide workers the terrain for engaging capitalist institutions that impinge on working conditions. Trade union existence and right to operate as legitimate organs of the labour force was a hard earned right in industrialised countries of the West where they first originated. In several developing countries the emergence and acceptance of trade unions as representatives of working people even though less contentious was accompanied by stiff resistance from the mainly foreign employers and the colonial state which represented their interests.

Pursuing workers' interests currently involves a variety of trade union activities in two broad areas. The first is the workplace where trade unions provide workers access to economic resources that are direct outcomes of their production activities. Secondly trade unions represent workers' interests on national organisations and institutions responsible for evolving public policy. Activities devoted to defending the rights of workers provide the platform to pull resources together and undertake collective actions for improving the working conditions of members.

The right to organise and the conditions for exercising this right are recognised as a fundamental human right, enshrined in two core conventions of the ILO, Conventions 87 and 98. These conventions grant all working people freedom of association and protection of their right to organise and collectively bargain. At the national level these conventions are translated into constitutional and legislative provisions to ensure that workers' organisations have some legislative protection to operate devoid of interference from employers and state.

Trade unions have since their emergence in the nineteenth century acted as lead organisations for working people. In addition, many trade unions, including those that emerged from colonial rule, played pivotal roles in the political history of their 
countries (Harrod \& O'Brien, 2002; Kester G. , 2007; Kraus, 2007). The unique position of labour movements in the governing process of African states has been highlighted in works such as Adu-Amankwah (1990), Kester (2007), Panford (1996) and Ninsin (1989). Organised labour in Ghana, Namibia and South Africa, for example, played important roles in national struggles for political independence. For Kester, the peculiar character of African trade unions places them in a strategic position within the current multiparty democracies operating in their respective countries (2007). Their location in crucial sectors of the national economy in African countries and their presence in urban administrative centres make their struggles a ready challenge to the stability of the nation state (Kester \& Sidibe, 1997). They also promote citizens' participation in the governing processes through their operations.

In spite of their strategic economic and political location, trade unions cover a restricted proportion of the national labour force. In Ghana, as in most other SubSaharan African states, union coverage is about one quarter of formal sector workers therefore a small minority of the working population (Kester \& Sidibe, 1997). Their limited coverage however, does not diminish their function as a significant index of democracy. Through their existence and operations, trade unions occupy a unique place in the current process of democratisation and the promotion of good governance in Africa. The range of issues they target as constituting workers' rights border on the social. In Nigeria for example, trade union resistance to government's attempts to deregulate petroleum prices had widespread support among Nigerians irrespective of their political, ethnic, and economic location in society. The Nigerian Labour Congress (NLC) in this instance reveals to the non-unionised segments of the working population the value of organisation for the defence of basic citizen rights. The non-unionised labour force gather lessons on how association around social needs enhances the empowering potential of organised groups (AduAmankwah, 1990).

Global political and economic developments over the past two decades and a half continue to undermine the existence of trade unions. Globalisation outcomes like the development of information technology and expanded role of private capital in national development impact production systems and their accompanying relations. Ultra-liberal notions of economic development drive global economic strategies from which national policies evolve. Structural Adjustment Programme (SAP) is one such policy outcome that dominates economic planning world-wide. Already, national borders have been eroded by SAPs embarked upon by African countries under the supervision of the twin international financial institutions, the World Bank and the International Monetary Fund (IMF) and the binding impact of World Trade Organisation (WTO) treaties and agreements. SAP policies insist that governments reduce their budget deficits through wage rationalisation and withdraw from direct involvement in production by privatising all state owned enterprises (Abugre, 2001). Privatised enterprises are taken over by profit seeking transnational corporations (TNCs) who regard as wasteful investments that promote labour 
rights. TNCs are less susceptible to the influence of democratic institutions and changes in government policy. They are capable of flouting both global and national instruments erected to defend working people.

The disappearance of nation states in production and social provisioning as well as the hostility towards organised labour are direct outcomes of the predominant ideological orientation that underlies global policy. Ultra liberal persuasions identify private capital as the most efficient in advancing development and insist that governments, as the poor performance of public enterprises have shown worldwide, have no business in production. The responsibilities of governments stop at providing the enabling environment for the operation of private capital. Individual citizens are responsible for their social protection. Investment in the social wellbeing of labour constitutes a drain on profits that could otherwise be invested in making enterprises grow and provide more jobs. Trade unions are seen as having primarily one objective: increased wages through their main tools, collective bargaining. Unions within the ultra liberal or conservative tradition therefore are presented as selfish organs pursuing parochial interests that do not make for enterprise competitiveness and growth. Management practices are therefore geared towards making the functioning of trade unions irrelevant in the workplace.

Harrod and O'Brien (2002) underscore Hoogvelt's observation that SAPs are an example of global government whose major objective has been a reconfiguration of world labour market. SAP policy outcomes everywhere have resulted in more flexible labour market provisions. The workplace no longer gives workers the opportunity to associate as before, and the proportion of workers with the tradition of organising has suffered a drastic reduction (Mozhayev, 1990). Mozhayev observes further that workers in the old trade unions in industrialised countries have been replaced by "golden-collar workers": highly skilled and well paid workers who have no interest in organising. Such changes have undermined trade union strength, visibility and relevance.

The threat of the uncontrolled strength of global corporations to sustainable development constitutes one of the core concerns of the Millennium Development Goals (MDGs). The MDGs identify good governance as a means to safeguard the benefits of globalisation and ensure sustainable development. Good governance, a core liberal democratic principle, provides the tools for checking the excesses of globalisation. Democracy is the primary basis of legitimacy for non-controversial systems in present day political life. The central idea to all forms of democracy is the rule of law and the proclamation of formal equality of individuals in society with inalienable rights. Which rights are protected through citizens' participation in national decision-making.

Participation is granted via two modes: direct involvement in decision-making in matters affecting the individual; or indirect involvement through elected represen- 
tatives. Implicit in representative participation is the idea of social contract which Knight et al (2002) describe as a tacit agreement between the citizens and elected governments where citizens contribute thinking to government decisions and take responsibility to abide by the decisions once made. As a result of the generalised weakness of multi-party political democracies to manage capitalism in its globalised form, citizens in several parts of the world have left their governments to govern with little concern for what the governments do (Knight, Chigudu, \& Tandon, 2002). There is an apparent withdrawal of citizens from participating in multiparty democratic processes like voting, attendance at meetings and holding public office (ibid).

The extent to which citizens can and do participate in decisions that affect their lives remains one area of particular concern within current multiparty democracies. The underlying assumption of these democracies is that decisions of elected representatives will always be in the interest of the electorate. But events around the world reveal the contrary. For most democracies operating at the moment, political participation is limited to four yearly ritual of electing representatives who have the right to make decisions. There is the increasing recognition that one way in which democracy can be consolidated is through a broadening of the landscape to allow citizens greater participation in decisions that concern them. Once again the MDGs recognise participation, an index of good governance, as one of the critical conditions for the survival of democracy; and democracy itself as a necessary condition for sustainable development.

The debate on how to address the crisis in democracies has tended to concentrate on how citizens and especially representative organisations can participate more effectively in national decision-making institutions and processes (Knight, Chigudu, \& Tandon, 2002). Generally trade unions have been recognised as important for increasing democratic control over public and state policy and through this, for averting the tendency of capital to be exploitative and governments to be authoritarian (Wood, 2004). For organised labour, however, one measure of democracy is the levels of participation in work place decision-making or industrial democracy which promotes the notion of social contract in the workplace. Industrial democracy is part of the effort made by labour movements to extend democracy throughout society because of the belief that if arbitrary situations are allowed to persist in one section of society they become obstacles to the progress of democracy in others (Adu-Amankwah, 1990). Trade unions therefore provide useful vehicles for engaging the excesses of globalised capital because of their direct engagement with TNCs.

Unions however find themselves involved in a stiff struggle to justify their relevance and legitimacy in the face of global and national policy environment that threatens their very existence and undermines their legitimate claims to decent working conditions. The rapid and unrestrained expansion of western capital through globalisation erodes jobs and narrows the ability of nations to create decent 
secure employment. The basic assumption on which globalisation thrives derives from an ultra-liberal economic persuasion that has re-positioned labour within the production process as an economic entity whose cost acts to reduce company profits and hence efficiency. Bowles explains that labour, irrespective of its location, has been challenged by many factors in the period marked by contemporary globalization (Bowles, 2010). The policies based on this and other related assumptions have resulted in changes in management worker relations at the workplace, evolved several forms of informal or atypical employment conditions which all act to threaten job security. It is within such a space that workers' movements find their greatest challenges, for labour is increasingly re-located beyond traditional union organisational spaces. The outcome of such policies on union strength and existence has been the subject of discussion in several circles and the impact well documented. So have the alterations in contours of union operational terrain that have accompanied economic and political restructuring in the 1980s and '90s (Wood, 2004; RoyChowdhury, 2003; Addison \& Schnabel, 2003; Heery \& Fosh, 1990; Fairbrother, 1990).

The need for unions to reorganise to better protect working people has long been recognised in all countries including Ghana. Among the steps taken by European trade unions to address the changing conditions of labour movements are a redefinition of union role and purpose, political campaigns, mergers, new recruitment drives and service rendering to members (Steele, 1990). In Ghana as in other African countries strategies to this effect have taken the form of expanding union coverage into the informal sector, one area hitherto ignored by organised labour, and improving female union representation and participation. Others include union mergers and splits and insistence on greater workplace or industrial democracy. These have in most instances impacted on union structures.

Trade unions have developed structures and processes to guide their operations in order to secure an institutional location within the capitalist mode of production relations. Overtime maintaining these structures have become goals in themselves as trade unions struggle to improve upon their legitimacy and relevance in national production systems. The pursuit of building organisations have been decried in some circles to have cost unions the ability to operate as democratic institutions (Linden, 2008). Unions however exist as representative bodies and derive their power to pursue workers' interests from the very workers they represent. Trade union structures and processes provide the basis for meeting membership needs and aspirations as they define membership rights and responsibilities as well as demarcating the scope of various hierarchies within the unions. Issues of union democracy are at the centre of the defence of workers' rights because a strong union is one which promotes the social contract with its membership. Unions' organisational structures provide the vehicle for sustaining this contract between trade unions and their members. Unions should therefore be subject to democratic rules and principles if they are to meet their primary responsibility to their constituents. 
Union democracy has engaged social scientists of different persuasions for different reasons and at different times. The period of adjustment-1980s to the end of the 1990s provided most researchers additional reason to examine trade unions, in terms of their democratic practices. These works, concentrating mainly on unions in western industrial countries, utilised theoretical backgrounds that directed their choice of the areas of union internal democracy they chose to examine. The various persuasions outlined by Heery and Fosh (1990) which are pluralism, feminism, Marxism, conservatism and political economy have been the main lenses for analysing trade union democracy leading to several and sometimes conflicting conclusions. One consistent conclusion however, is that unions presently are neither losing their relevance nor disappearing.

The manner in which the utility of trade unions to members and the wider society is conceived depends on the theoretical orientation within which one operates. The five theoretical orientations identified by Heery and Fosh (1990) debate union relevance and legitimacy differently. The Marxists assign trade unions a social transformatory role with the belief that unions together with the socialist party will replace capitalism with socialism and eventually communism; which system will ensure that production and its end products will promote the welfare of workers. The conservatives at another extreme limit union role to its direct membership at the enterprise level. Conservatives question the benefit of trade unions to the broader national interest, arguing that trade unions only serve the narrow interest of members and their demands are not always beneficial to the wider interest of society. For feminists, the social utility of trade unions is severely undermined by their present structure and organisation which benefit male members mainly. In analysing the corporatist role of trade unions, political economists see trade unions' engagement in policy as instrumental for all manner of working people (Heery \& Fosh, 1990). The concessions that trade unions have to make in order to sustain the political exchange required are more of short term losses which are eventually compensated for by the long term benefits which they realise. Thus the theoretical orientations adopted in any study of trade unions determine the areas of union behaviour and existence that are captured. These orientations also underlie national and international conceptualisation of trade union role and state attitude to organised labour.

In terms of their orientation the examination of trade union democracy has tended to be issue specific and not encompassing the specific system upon which union democracy hinges, which are the union structures which direct their operations. Such persuasions have been utilised to examine the relationship between trade unions and their members, accountability and representation, directions and forms of union renewal and the use of ballots in union decision-making. Very little consideration has been given to the examination of alterations in union structures and operations to counter the threat posed by global political and economic events. The 
policy outcomes have been limited to reactive strategies designed to ensure trade union survival. Unions however continue to grapple with issues of representativeness and effective strategies for organising within a context of an industrial relations environment which challenges the very notion of trade unionism.

\subsection{PROBLEM DEFINITION}

The presence and operations of trade unions constitute important index of levels of democracy in any nation state. Economic reforms and the resulting socio-economic transformations heralded by globalisation undermine the very existence of trade unions. Globalisation presents benefits that can be realised if the primary responsibility of nation states to protect the human rights of their citizens can be guaranteed. Globalisation processes like trade regimes and the regulatory framework which support the transfer and operations of capital across national borders, however, undermine labour friendly institutional mechanisms.

Nation states have individual and collective responsibilities for promoting development in a manner that is sustainable. Citizens' participation in national governance is an important avenue for ensuring that governments continuously promote the political systems and structures for sustaining development. By political and economic positioning trade unions in Ghana find themselves in the forefront of the struggle for responsible governance. The unique structure and composition of trade unions such as the Ghana Trades Union Congress (GTUC) provide them levels of representation and legitimacy to ensure that governments live up to their social responsibility to their citizens.

The dominant policies of globalisation is the re-configuration of the labour market through 'flexibilisation' provisions, and the retrenchment of the welfare state supported by notions of international economic competitiveness which regard social wages as a drain on corporate profits (Bowles, 2010; Harrod \& O'Brien, 2002). The resulting labour market changes have informalised work relations and created forms of atypical work and thereby diffusing the traditional sharp distinction between workers and employers as well as the defined confines of workplace. In addition, government onslaught on organised labour and labour rights, which intensified during the adjustment years of the 1980s and 1990s, create the erroneous impression that trade unions are a disincentive to much needed foreign capital flows. Such efforts, Fairbrother concludes, are all designed 'to create a flexible and manipulable public service workforce' (1990, p. 147).

Trade unions have adopted various forms of strategies to cope with the challenges of altered labour market conditions arising out of globalisation. Such efforts are mainly directed towards providing direct services to members, expanding coverage and altering internal structures to allow avenues for interest representation of various groups like females members. The strategies which have spanned the national 
to the workplace levels have been identified broadly by Fairbrother as union renewal (Fairbrother, 1990). For him, union renewal is the manner in which 'unions reorganise and recompose themselves' to meet the problems of work and employment imposed by economic restructuring. Because union renewal is underscored by a continual fight and campaign for collective participation and agreement where workers' collective interests and concerns are expressed, union democracy becomes a crucial feature. Changes largely designed to ensure union survival and effectiveness in defending workers' rights are the modes for reconfiguring union structures to respond to changing labour market situations (Fairbrother, 1990).

Globalisation and its attendant economic restructuring that challenge the basis of trade unionism create conditions that trigger union renewal. These conditions include the restructuring of work, changes in the patterns of work, industrial relations processes and institutions. Compelled to redefine their role and purpose, unions have responded to the changing conditions under which they operate by resetting the parameters of union concerns in several ways. Renewal strategies impact union structures in ways that do not necessarily evolve in democratic outcomes. Effective renewal strategies however, are those that create democratic unions to maintain their leadership role in the struggles of all working people. In the peculiar case of Africa, where the need to secure responsible governments that design policy in the interests of its citizens is paramount, unions have to be democratic institutions.

Effective union response to globalisation depends on improving the relevance of the labour movement to its members, and enhancing further membership representation and participation. Such efforts are dependent on internal structures of union governance which underlie union internal democracy. Union democracy is historically specific, better viewed within the context of changes in broader socioeconomic processes generated by globalisation. Increasingly the work terrain has altered dramatically for all workers and no longer supports the original modes under which unions organised. The new strategies evolved by unions therefore have to address how their default mode of operation can be re-designed to take on board new forms of work and work relations. How unions develop and negotiate renewal strategies within their circles, are still being debated. It is not clear for example how unions can adapt their structures to offer effective representation to informal economy workers despite decades of efforts to extend coverage to this section or improve on gender democracy beyond just adding on more women (Webster, 2005; Ledwith, 2006). In addition, the role of leadership and membership in devising and revising renewal strategies are not very clear. The nature of internal dynamics within the labour movement and the specific issues of internal democracy brought to the fore in the heterogeneous fusions of union membership are yet to be resolved. The diverse membership of trade unions are bound to put varying pressures on union structures that will be compounded by the intersection of renewal strategies designed to address sectional interests. Such pressures are bound to affect how members access their unions for meeting the varied workplace concerns. The un- 
derstanding of these issues is critical if unions are to offer working people the necessary tool to combat the excesses of globalisation. The specific responses of unions to dwindling membership and the nature of power sites that have emerged within unions have to be unravelled for a better understanding of the varied trajectories that union revitalisation have taken. How unions respond to the emerging internal dynamism shape their functional terrain and direct them towards sustainable revitalisation as effective workers' organisation for meeting the challenges of globalisation.

\subsection{STUDY QUESTIONS AND RELEVANCE}

As the main trade union centre in Ghana the GTUC and its national unions have borne the brunt of economic reforms and the resulting labour market changes. There have been several efforts to retain their dominance as workers' representatives through the institution of several strategies. This study sought to explore how specific trade union renewal strategies instituted by the GTUC and its national unions to counter globalisation challenges impacted union internal democracy. Union internal democracy was identified as ability of members to utilise their unions in pursuit of their struggles. The goal of the study raised these specific questions:

i. What are the exact challenges of globalisation facing trade unions in Ghana;

ii. How have the GTUC and its affiliate national unions responded to these challenges;

iii. How have renewal strategies impacted internal union power dynamics;

iv. What are the implications of the emerging power dynamism for sustaining effective union revitalisation?

The manner in which national wealth is created and distributed can promote or deny individual rights. Policy choices are therefore important for sustaining human well-being for they determine the extent to which institutions of good governance effectively guarantee citizens' rights, personal security and access to justice. For governments to live up to their role to promote development, there is the need for a sustained nurturing of citizens' capacity to respond to changes and insist that their governments live up to their responsibility. As representative organisations, unions act to facilitate the connection between working people and their governments. Trade unions have, since the introduction of structural adjustment policies in the 1980s, lost their political strength and social appeal. The loss of credibility and effectiveness is the result of changed philosophical orientation in industrial relations thought that assigns greater importance to capital and less to the workers whose labour forms a critical part of the production process. The damage to unions is not so much in terms of decreasing membership due to job losses and the introduction of flexible forms of work that undermines job security but more in terms of the shift in the conceptualisation of the position of labour in industrial relations thought. For this re-conceptualisation appears to cast workers pursuing legitimate claims in poor 
light presenting them as irresponsible and insensitive to broad national goals of economic prosperity.

As organisations that transcend the usual political, ethnic and other forms of divisive associations that tend to plague African states, trade unions find themselves in a unique position to maintain the momentum for evolving and sustaining development alternatives that respond to national needs. Trade unions, through their efforts at defending the rights of workers, operate as vehicles for building citizens' capacity to interrogate policy changes. Radical approaches to strengthening the trade unions in the present context of globalisation which threatens their very existence are required if unions are to maintain this role. Such approaches depend on changes in the organisational efficiency of trade unions that enhances their constituency base and legitimacy in order to support a continual fight and campaign for collective participation and representation on the specific strategies unions adopt. Trade unions everywhere, including GTUC, have themselves recognised this fact and devised strategies to expand membership and recover their relevance. Renewal strategies have usually been reactive, designed to repair policy damage to work and working conditions. Investigating how union structures and processes have responded to renewal strategies should enhance understanding of the forms of alterations in union representative and participation structures that are needed for unions to defend workers' right and promote a basis for evolving policies that respond to the developmental needs of people in Ghana. The outcome of the investigation should also inform the conceptual debate on interactions between trade union renewal strategies and internal democracy and how the ensuing tensions evolve, as strategies force changes to union organisational mode.

\subsection{CHAPTER COMPOSITION}

Union responses, mainly reactive as mentioned, have sustained their existence and improved their legitimacy over time. The trend for altering the nature of work and work relations have seen unions extend their interests into working terrains that challenge the very principle of their existence. These strategies have varying successes and stand to improve if there is better understanding of what changes within union structures can best serve the interest of all working people irrespective of where they are located. The first chapter discussed the present situation of working people and their movements, the changing political and economic environment that criminalises unions and pose them as a disincentive to foreign direct investment and therefore job creation for national development.

Several factors both internal and external inform union strategic choices and in the long run significantly impact their success. The second chapter situates the study within the discourse on globalisation, union renewal and democracy. It examines the manner in which economic reforms have restructured work and production relations to undermine the existence of trade unions. It notes further that the impli- 
cations of union renewal for their internal dynamics is better understood in a framework that studies unions as sites in the general struggle within the capitalist mode of production. The rationale for the choice of study methods, sites and union strategies form the subject for discussion in Chapter Three. It notes the suitability of the case study approach and provides the basis for the choice of the GTUC and its national affiliates for study.

Trade unions straddle relations among workers as well as those between workers and their employers. Unions also mediate the relations between workers and the state mainly by intervening within economic and political policy enactment. These relations are potential sites of conflict as various partners in the relations vie to gain control over contending interests. It is in mediating within these environments that unions reveal their relevance and effectiveness in the working lives of their members. How globalisation has impacted the ability of unions to mediate within these sites and the responses the GTUC and its national unions have evolved form the subject of discussion in chapter four. The chapter discusses also the issues that have informed the choice of strategies and how specific strategies stand within union range of priorities.

The membership of the GTUC and its national unions, like all trade unions, do not constitute a homogenous group. This derives from the fact that workers' experience of class exploitation in the workplace takes various forms and is mediated by social and economic factors. Outside the workplace, workers hold other social positions like their gender, ethnic, race, cultural placement, that act to modify their working class positioning and therefore their class interests. In addition, workers are located in completely different workplaces producing marked differences in working experiences. Some workers are better placed than others and this affects the manner in which they accessed union power tools for the pursuit of their interests. Chapters five, six, seven and eight explore how different union memberships impact the nature of representation and participation that are offered in union structures.

The GTUC and its affiliates have utilised a diversity of approaches to organise informal economy workers. But after several years of union activity in the informal economy, organisation and representation still remain daunting for unions. Success stories have been difficult to replicate and the same methods continue to be used in the hope that they might work. The fifth chapter explores the peculiar nature of informal economy workers' representation within the GTUC and its national unions and how it impacted the nature of voice the unions provided for accessing their rights as working people in Ghana.

The gender dynamics within unions were forced into the open as globalisation took its toll on union density compelling unions to devote greater attention to the concerns of working women and their location within the labour movement. Gender democracy involves the examination of the complex interrelationship between 
women and men's positions in the unions and the workplace. Unions' efforts in this connection, though substantial, are yet to make the desired impact. Chapter Six is devoted to the examination of how gender democracy strategies have impacted female trade union members' consciousness and the potential it has for women to use the space provided to transform union structures and processes that disadvantage female members.

Chapters Seven and Eight examine how strategies directed at participatory structures in the regions and districts as well as the enterprise levels have impacted internal democracy. These two chapters note the forms of power tools available for union members pursuing their workplace struggles and the nature of struggles that are waged in these three locations within the union structures. These chapters note how the strong sense of union relevance, in the face of institutional restrictions and resource constraints, is maintaining the members and helping to ensure that unions continue to provide the vehicle for meeting the challenges of globalisation.

Globalisation for the moment continues to change the working space and relations that evolve as people engage in production to meet daily needs. The trend appears to be a displacement of working people from formal sites on which earlier notions of trade unions were developed. There is the need therefore to rethink trade unionism in terms of structures and processes appropriate for dealing with the varieties of work and gendered social relations that permeate the work space and union structures. Union structures determine their systems of governance and how they maintain internal democracy. The structures are usually the direct outcome of historical events requiring changes to internal operating systems in order to accommodate forms of internal dynamisms that emerge as union revitalise. 



\section{Chapter 2}

THE CONTOURS OF UNION GOVERNANCE AND DEMOCRACY 


\title{
2 THE CONTOURS OF UNION GOVERNANCE AND DEMOCRACY
}

\begin{abstract}
The connection between globalisation, labour market reforms and the current trade union situation is discussed within the context of the mediating role of the state in shaping new notions of development, and in legitimising globalisation. The examination of the manner in which economic reforms are conceived and their impact on union's operations and structure reveals the underlying ideologies that undermine the very logic of trade unions' operations and existence. Work and workplace reforms impact trade unions prompting the need for renewing union relevance as legitimate representative organs of workers. When unions set out to develop strategies for combating the effect of globalisation on their functions and existence, their internal cohesion, in terms of membership solidarity, is bound to be affected. Union renewal studies point out union internal democracy as important for union revitalisation, very little room is however provided to examine in detail how renewal affects internal democracy and how the renewal strategies can benefit from union internal democracy.
\end{abstract}

\subsection{GLOBALISATION AND ECONOMIC RESTRUCTURING}

Basically discourses on economic development present globalisation as the dominant feature shaping national economic and social conditions around the world (Buckman, 2004; Munck, 2002). There is however some disagreement as to the forces driving it, its origins and final beneficiaries. Its economic, social and political impacts are also contested (Bowles, 2010). The debate on the impact of globalisation spans a range of views from what Buckman (2004) classifies as the globalists on one end to anti-globalists on the other. Globalists in the form of state and non-state actors like the governments of the USA, UK and Japan and the IMF and World Bank posit that globalisation is the predictable outcome of advances in technology made possible by Western industrialised states. Globalisation, they emphasise, has positive outcomes for countries which position their economies to draw out its benefits (Munck, 2002; Buckman, 2004). For anti-globalists, globalisation is meant to benefit just a few. The failure of some nations to develop is the logical outcome of the inherently exploitative dynamics within globalised capitalist relations (ibid). Globalisation has had its fallouts. Indeed, increasing global poverty, world-wide environmental degradation and the current economic crisis have renewed scepticism about 
its benefit and sustainability. The negative impact of globalisation is recognised by both anti-globalists and its adherents such as the giant financier Soros who expresses concerns about 'what might be politely termed its side-effects' (Munck, 2002 , p. 54). Such writers warn that the free rein given to market forces under globalisation requires some check if the social needs of the majority of the world's population are to be met (Haynes, 2005; Munck, 2002).

The notion that globalisation is a recent phenomenon is debunked by observers who insist that what is currently termed globalisation is a phase in the development of capitalism (Haynes, 2005; Buckman, 2004; Rupert \& Smith, 2002; Sutcliffe, 2002; Sutcliffe \& Glyn, 1999). Sutcliffe and Glyn use statistical arguments to show that celebration of globalisation as a great and novel event is greatly exaggerated (Sutcliffe \& Glyn, 1999, p. 111). While Sutcliffe in a later work conceives of globalisation as 'a major intensification of long established tendencies' of capitalism, Buckman's outline of the emergence of globalisation points to 3 major phases or waves in Western capitalist development that have been global (Buckman, 2004; Sutcliffe, 2002). The phases represent points in expansion of Western European interests into the socalled 'new worlds' of the Americas and Australasia, Africa and Asia, which began with the explorations of Columbus and Vasco da Gama in the fifteenth century. Subsequent colonial expansion, a response to industrialising Europe's need for raw materials and markets, constitutes the second phase which ended with the onset of the Second World War. The political and economic changes resulting from the Second World War and decolonisation reconfigured international power balance which allowed the USA to emerge as a world power. Her presence as a dominant state entity called for a restructuring of global political economy that will provide the US access to the resources of third world countries. The third wave of globalisation therefore enabled a continuation of political and economic domination of Western interests which were not reliant on the colonial superstructure (Buckman, 2004; Munck, 2002). In essence globalisation is the latest form that Western capital has assumed to dominate the world economy. This form gives room to state players hitherto excluded during colonial rule.

The disagreements in the discussion on globalisation go beyond its novelty and social and environmental impact; there is little agreement about what drives it. Buckman explains that the right-leaning social scientists posit globalisation as 'a product of an inevitable rightward swing in politics... a predictable consequence of the march to technology' (Buckman, 2004, p. 4). On the left of the political debate, the anti-globalists agree that globalisation is the conscious manipulation of a concurrence of favourable factors (Buckman, 2004; Munck, 2002). Reviewing the origins of globalisation they show that it is the outcome of a mix of technological advances and the manipulation of the global financial institutions, political power of dominant countries within Western Europe, the USA, and Japan and a supporting ideology. Industrialised countries operate in tandem with the international financial institutions (IMF, World Bank, and the WTO) and compliant governments to ensure 
the world-wide implementation of economic and political structures that support globalisation.

Globalisation as a politically engineered phenomenon is also ideologically driven. It has its supporting ideology in the free market neo-liberal philosophies propounded by a group of economists based in the USA and UK: the 'Anglo-WashingtonChicago Consensus' (Buckman 2004, p. 58). It encompasses economic decisions that remove market and trade barriers, to the advantage of a few Western industrialised countries (Buckman, 2004; McMicheal, 2001). Political and socio-economic dimensions of globalisation reformulate international and national production relations leading to fundamental restructuring of labour markets (Buckman 2004; McMicheal 2001). The fact that globalisation is not a naturally occurring world political and economic event but one that has been consciously manipulated and supported to survive and expand to embrace all nation states is informative. For it stands to reason that it is meant to benefit those responsible for its implementation.

Globalisation as a concept encompasses several issues. First it conveys a set of notions and secondly it denotes a system of political, economic and social organisation (Haynes, 2005; Rupert \& Smith, 2002). As a set of ideas, globalisation is conceptually derived from the existing concept of capitalism. Even though there is some agreement that globalisation has a special relationship with capitalism, there is disagreement as to whether it represents a new stage in the development of capitalism or is a logical next stage after capitalism. McMicheal explains however that globalisation is a phase in capitalist development just like colonial rule with its own distinct social and economic relations (2001). Globalisation encompasses attempts at capturing new developments in the spatial organisation of capitalist production relations (Haynes, 2005; Rupert \& Smith, 2002; McMicheal, 2001).

The debate about globalisation seems to present several polarised positions, in terms of its overall impact: whether its outcomes are at all beneficial, its geographical and political scope of influence as well as its origin and novelty (Haynes 2005; Buckman 2004; McMicheal 2001). The discussions seem to point to the fact that globalisation is a politically engineered phenomenon benefiting from a concurrence of factors utilised to spread neo-liberal economic forms of social organisation. The notion that some parts of the world or sections of the world's population have been excluded from globalization is dependent on how globalization is conceived. A limited explanation of the term exclusion can incorporate self-blame suggesting that some parts of the world are not part of the globalised economy as a result of some forms of inherent weaknesses on their part. The formulation of exclusion as part of globalisation improves the understanding of the interconnectedness of world production forms. Globalisation constitutes a socio-economic and political system within which production and distribution of goods and services are undertaken. Precarious existence normally conceived as located on the margins of economic activity is therefore part and parcel of the globalization economy. This aspect of 
globalisation is important for discussions of the present situation within trade unions because it reveals that workers and their organisations should constitute a key component in discourses on globalisation.

\subsection{THE NATION-STATE UNDER GLOBALISATION}

The future and function of the nation state within globalisation has been one of the major issues attracting intense debates. The concept of the nation state adopted for discussion here is that derived from Haynes who confines the term to political and geographical territories, administered by national sovereign entities (Haynes, 2005, p. 3). There are those who celebrate the eventual demise of the nation-state as captured in Polyani's epic 'Death to the nation state' or Ohmae's prediction of a movement 'into a borderless world' (Haynes 2005: 4; Munck 2002: 52). The conclusions drawn by such positions, according to Munck, is that globalisation whose operations assume a borderless economy has 'reconfigured the nation-state out of existence' by eroding its influence and relevance as an economic and political entity (2002: 54). The ability of nation states irrespective of their varying contexts to craft similar policy choices and corresponding identical outcomes is cited to support the 'self-cancellation of the state ... and the rise of a borderless world' (Teschke \& Christian, 2002, p. 176).

The demise of nation state thesis is contested on two fronts. The first is that globalisation only 'emerged with the active designs of powerful nation-states' whose existence is important to ensure its survival and secondly that the present 'internationalisation' of the world economy does not equal 'globalism' (Munck, 2002, p. 55). The world economy is nationally based and far from merging into a global integrated economy. Önder, (1998) insists that the national is still relevant economically, politically, and capital under globalisation operates from a national base. International governance institutions like the IMF, World Bank and the WTO which work to further the interests of global capital are also nationally based deriving their power from specific nations whose interests they promote (Wood 2004). Globalisation therefore is controlled and organised from a national base.

Haynes finds some common ground of agreement among both globalists and antiglobalists about the relevance of the nation state under globalisation. There is a general acceptance that the technological, political, economic and cultural aspects of globalisation that are key in influencing domestic outcomes are carefully mediated by the state (Haynes, 2005). This common ground diverges however when it comes to determining the duration of the mediating role of the nation state and what likely changes it stands to undergo. Teschke for example does not believe that the nation state is on the verge of extinction. Nation states rather facilitate the success of global capital and cannot be victims or losers under globalisation (Teschke \& Christian, 2002). The increased internationalisation of capital within globalisation has not resulted in a decline of the nation-state, in terms of its relevance and function, neither 
is there in motion a process of gradual extinction or loss of relevance. Nation states serve both as instruments for domination and as conduits for the expansion and reinforcement of globalisation (Wood 2004: 26).

Sutcliffe, just like Burnham, affirms that the interests of globalised capital are located within the national space. However their economic policies will continue to be dominated by the concerns of global economic interests in so far as nation states remain part of the global capitalist system (Burnham, 2002, p. 123; Sutcliffe, 2002). What stands to change is the form and nature of the nation state. While their economic oversight role for implementing policies that protect globalised interests intensifies, their social roles diminish and they lose their democratic legitimacy (Munck, 2002; Teschke \& Christian, 2002). The result is national tension as the territorially defined base of capitalism's political authority conflicts with its economic expansion threatening sometimes national unity (Rupert \& Smith, 2002). Wood predicts that as a result, 'some may fragment to form smaller national entities ...others may join larger regional associations. But the forces tending to prolong the historical connection between capitalism and the nation-state are very powerful, indeed rooted in the very nature of capitalism.' (Wood 2004: 29). The mediating role of the nation state undergoes constant change in order to continue providing the legitimacy that globalisation requires to survive.

Foreign debt burden and Foreign Direct Investments (FDI) transfers constitute important avenues for the spread of globalisation and instruments for ensuring that nation states play to the rules of the game (Harrod \& O'Brien, 2002). The SAP imposed by the IMF/World Bank on developing and transition economies in Africa, Asia, Latin America and Central and Eastern Europe as a solution to their debt burdens formed the conduit for the expansion of globalisation. Significant changes in the economic landscape of adjusting nations were the increased internationalisation of their economies through the adoption of economic practices that sought to promote international economic interdependence at the expense of local national interests. International agencies and supranational bodies (World Bank, IMF and WTO) set up to 'deregulate market access, trade and capital flows' gained more prominence in the national economic policy making them institutions with authority to subject national economic policies to international scrutiny (Streeck \& Hassel, 2003, p. 360).

SAPs serve as an avenue for promoting export=oriented economic growth model of development that endorses the takeover of production by TNCs through the transfer of FDIs. Creating an environment conducive for the operation of TNCs requires a curtailment of certain roles and functions of the state. The first is its economic function as direct producer and the second is its welfare responsibilities for the citizens whose interest it purports to serve. The implementation of the neo-liberal economic model which emphasises economic growth through production for export meant 'not a smaller role for the state but a major change in the nature and direction 
of that role' (Önder, 1998, p. 50). The new role was established through the implementation of polices, legislation and the creation of institutions that facilitated the integration of national economies with transnational capital or foreign direct investments. Haynes (2005) explains that adjusting countries 'abandoned or downgraded national development strategies... based on state-led programmes and import substitution polices - and rejected nationalization of foreign assets' (Haynes 2005: 140). SAPs meant an internal restructuring of state powers and apparatuses not the curtailment of its economic role (Haynes, 2005; Önder, 1998).

The state assumes the position of an agent for the promotion of globalisation advancing the interests of transnational private capital, the ultimate beneficiary of globalisation (Harrod and O'Brien 2002). The state also acts as a mediator between domestic and external interests through political, economic, and cultural means (Teschke \& Christian, 2002). Citing the example of Germany, Teschke and Christian conclude that the state acts more as a conduit for transmitting the interests of domestic capital and less in the interest of regional and international institutions (2002, p. 181). That the restructured state under globalisation does not serve the interests of its citizens but those of capital is underscored by Haynes who states that the 'key effect of globalisation is to enhance the porousness of state borders and to increase the significance of external actors for many domestic outcomes' (Haynes, 2005, p. 3).

TNCs have become significant actors in the debate on the so called reduction of state power. As the ultimate force behind globalisation and its direct beneficiaries, TNCs' command over capital and their ability to move capital, goods and services across national borders with ease give them considerable power in world politics (Haynes, 2005). Not only do they act to pursue the economic interests of their nations of origin they seek to always control, through direct interference and manipulation, national political outcomes in their host countries in order to ensure a politically more secure operational environment devoid of restrictions (Haynes, 2005).

One major aspect of globalisation has been the projection of ultra-liberal modes of capitalist economic organisation as the only framework that offers nations the means to meet the needs of their citizens. There exists an inherent disdain for alternative forms of economic development models. Önder affirms that global market forces and governance institutions deny nations states the opportunity to pursue any development model which is 'incompatible with globally prevailing neo-liberal norms' (1998, p. 65). Such a situation, Wood explains, denies nation states, especially the world's poorest, the opportunity to chart an independent course for development (Wood, 2004, p. 35). Thus economic globalisation 'undermines the state capacity to pursue independent macroeconomic and development strategies' (Haynes, 2005, p. 138). An insignificant number who dare try alternatives do so at the risk of hostile stigmatisation and ostracising. This situation, far from eroding the remits of the nation state, actually reinforces its role in mediating in local spaces of 
the nation for the pursuit of a grand agenda of sustaining the spread of globalisation.

As a political and economic arrangement, globalisation represents a system of interests. How it is conceived therefore serve either to highlight its major beneficiaries and project plight of the main losers. According to Munck any debate that presents the nation state as outdated and irrelevant only serves to dis-empower sections of the population, like workers, whose interests have been undermined by globalisation (Munck, 2002, p. 79). Thus the debate on the utility of the nation state within globalisation serves as part of its legitimising logic. Önder, (1998) suggests however that a better way of conceptualising the role of the state is to move away from viewing it as one with a diminishing role and to analyse it in terms of whose interests it serves. Burnham affirms this position when he advises that states have to be conceptualised not as "'thing-like" institutions losing power to the market...but rather in a context characterised by the intensive and extensive development of the global circuits' that involve particular interests (Burnham, 2002, p. 124). Conceptualising the nation state as essentially for the enforcement of the prevailing social order enabling the smooth operation of globalised capital, provides an avenue to subject it to a class analysis (Burnham 2002). This is because globalisation encompasses political and socio-economic decisions and as such involves class relations. The state is a regulative agency designed to ensure that forms of capitalist relations are maintained and reproduced (Burnham, 2002, p. 118).

Using class analysis makes it possible to see how the process of restructuring national economies involves class relations in the reconfiguration of national power and societal interests (Önder, 1998). The nation state serves actively in the formation and articulation of social relations. It also serves to obscure class antagonisms and struggles by diverting them into non-class forms like citizens' rights, international human rights. Such forms of expressions disorganises labour in its fights for better conditions (Haynes, 2005; Burnham, 2002). Alenjandro asserts as a result that any analysis of globalisation that does not capture the class dimension within the functioning of the nation state will be flawed, unable to reveal the threat globalisation poses to labour (Alenjandro, 2002, p. 200). A class analysis makes it possible to highlight the contradictory relationship between capital and labour on one hand and between state and labour on the other (Burnham, 2002, p. 117). Önder in his analysis of the political events underpinning the neo-liberal transformation of the Turkish economy, concludes that it is only a critical examination of the role and changes in the institutional structure and power balance within the nation state that the nature of the transformation becomes clear (Önder, 1998, p. 44).

If the state serves to advance the interest of its domestic capitalist class, it presupposes then that countries without a developed domestic capitalist class stand to lose in that in serving the interest of globalised capital they will be serving the interest of capital beyond their borders. What then are the implications for national develop- 
ment and labour's peculiar role within this process? The discussion about the relevance of the nation state to globalisation derives from conceptualising globalisation as an economic phenomenon. The fact still remains that the nation state is relevant in securing the interests of capital. Capital is tied to, and dependent on, the nation state to ensure survival in its globalised form. Debating the role and position of the nation state in globalising world economy should encompass attempts to understand better its globalising role. When this is done through a procedure that allows the class dimensions to be captured then the beneficiaries and losers can be better identified.

\subsection{RESTRUCTURING THE WORLD OF WORK AND THE SHAPE OF UNIONISM}

Because globalisation is about economic interests and production relations, its impact has been most decisive in the world of work. Globalisation policies have consistently targeted working people, triggering profound changes in the organisation of work and work relations (Munck 2002; Önder 1998). Reorienting national production to be internationally competitive is normally achieved through economic restructuring. Significant outcomes of economic restructuring are the changes in the structure of employment and the conception of workplace. Under neo-liberal reforms the situation of workers and their organisations changed both politically and economically. These changes included the removal of labour from national political processes and public decision-making which resulted in a deprivation of labour's power to exercise political pressure on the state in furtherance of its own interests (Munck, 2002). Labour's power in the workplace as an organised force also reduced drastically. These changes have occurred within an increased role of the state in setting the national industrial relations agenda while its space in direct productive activity diminished (Hyman R. , 1999; Sutcliffe \& Glyn, 1999). The redefinition of the space in which workers and their movements occupied in national development obliterated their role as prime agents for national development.

Önder, discussing economic reforms in Turkey, explained how economic restructuring meant a severe undermining of labour's traditional role in national policy formulation through policy exclusion (Önder, 1998). The new structures erected to facilitate economic restructuring severely curtailed labour's policy making access while expanding avenues for private sector interventions (Önder, 1998, p. 64). In a similar vein RoyChowdhury observed that changes in the position of labour within national policy making apparatus in India under public sector reforms undermined the political influence of trade unions (RoyChowdhury, 2003). The period of economic restructuring in Ghana has been noted as representing the most acrimonious state/trade union relations ever witnessed in the country (Graham, 1989; Panford, 1996; Boafo-Arthur, 1999; Ninsin, 1989).

The political and economic changes in labour's position arise out of globalisation's underlying ideology that shifts the focus of development from promoting the inter- 
ests of workers to those of capital (Munck, 2002; Önder, 1998). Globalisation as mentioned earlier represents a movement away from the immediate post-war economic arrangements in which the state played a prominent role in production. Governments were held 'responsible for managing the economy', state-owned enterprises tolerated and full employment made a priority of the state and unions (Munck, 2002: 23). Development theories then, Munck goes on to say, provided a key role for the state in ensuring that national interests were prioritised in all economic decisions (2002: 43). Trade union/state relations operated within the corporatist model under which 'the conduct of industrial relations is structured through a system of compulsory arbitration' (Munck 2002: 28 quoting Roxborough). The state had the ultimate responsibility for regulating the relations between labour and capital (2002: 43). Under this model of development, captioned as modernisation or importsubstitution-industrialisation, economic growth was promoted through a high purchasing power of workers (Önder, 1998). Globalisation's production-for-export model, thrives on low wages to keep down production costs and make national products competitive on international markets. Market access and market share for national products are the key national economic growth factors, not social welfare and employment creation. Preconditions for national development become 'efficiency and competition' (RoyChowdhury, 2003, p. 32; Streeck \& Hassel, 2003, p. 351).

As the conception of national development shifted from import substitution to export promotion, emphasis on production for national consumption reduced and private capital or FDIs gained prominent role in national economies. Neo-liberal economic policies posit that nations have to be efficient in the allocation of resources to sections of the economy that can effectively manage resources for economic growth. Private capital which has proven most efficient at utilising resources for economic growth has to be freed from social and public restraints (RoyChowdhury, 2003; Streeck \& Hassel, 2003; Munck, 2002; Önder, 1998). FDI, according to Haynes, becomes a 'crucial vehicle and conduit for economic growth...and exports' (2005, p. 139). The prime responsibility of the state was to provide the enabling conditions for the operations of TNCs which are the bearers of FDIs.

Within the operations of TNCs lie certain assumptions about production and its accompanying relations. By making global competitiveness a key ingredient for national development, countries are compelled to engage in a process of ensuring that their national economies become the most attractive destination for FDIs. The economic and political strength of TNCs introduces yet another dimension in international competition forging what has been termed 'the race to the bottom', where nations, in their bid to project themselves as attractive destinations for FDI, compete to outdo each other at lowering production and labour standards. The implications are dire for labour. Haynes explains 
'states are faced with increasingly stark choices regarding regulatory strategies: what processes of adjustment are necessary to attract and retain TNCs? The fear is that TNCs' production facilities are at liberty to move elsewhere, with attendant unwelcome impact: declining tax bases and increased unemployment' (2005, p. 139).

Munck (2002) therefore concludes that neo-liberal policies of globalisation and SAP and the resulting competition among nations for international market access produce practices that are 'constantly eroding labour's bargaining strength' (2002, p. 67).

Economic restructuring demands workplace restructuring. The ideological environment within which current workplace policies evolve is market driven and requires setting workers welfare secondary to corporate profits (RoyChowdhury, 2003; Harrod \& O'Brien, 2002). Workplace restructuring is usually carried in the framework of an economic thought that perceives the impact of trade union actions on industry and the national economy as negative. State officials' traditional rhetoric regarding trade unions these days, RoyChowdhury explains, is one that demands 'efficiency, discipline and productivity' (RoyChowdhury, 2003, p. 32).

Workplace restructuring is predicated on labour-focused cost cutting for profit maximization in employers' interests. Work flexibilisation is the catch word for lowering labour cost. Work flexibilisation includes forms of industrial relations practices designed to maintain a labour force that does not undermine national competitiveness through a demand for higher incomes and social wages (Önder 1998: 65). Teschke and Christian (2002) identify three labour focused measures employed to restructure the workplace. They are cost reduction practices, intensification of labour and the use of technology to replace labour (2002:177). Cost reduction measures come in the form of the 'casualisation of labour through part-time employment, if-and-when contracts ... self-employment and piecemeal work' (Alenjandro, 2002, p. 202). The underlying assumption is that by removing barriers to the manner in which workers operate at the workplace, productivity will improve and more jobs will be created (Munck, 2002, p. 73). The benefits of labour flexibilisation however are increased productivity at a lower cost and not more jobs. Labour flexibilisation results in reduced worker social overheads, workforce attitudes that thrive on individualism and high job insecurity. Within this back-drop, employers derive maximum benefits from workers in the absence of any policy that obliges them to invest in the welfare of their workers (Harcourt, 2004).

Labour protection policies and trade union demands for improved working conditions are posited as creating an inflexible labour market and serving to undermine national competitiveness (Munck, 2002). The outcome according to Streeck and Hassel (2003) is posed as a trilemma where full employment, price stability and free collective bargaining become untenable; any two can be achieved only at the cost of the third. Workers' interests cease to be legitimate national concerns, in fact, the demands of workers weaken national economies by draining resources required for 
economic growth. Besides union demands benefit only their immediate members and drives away capital crucial for stimulating economic growth (World Bank, 2004). The nation state no longer has any social responsibility towards its citizens. Social wage as a basic human right is transformed into a market commodity that individuals can access through their personal ingenuity (Munck, 2002).

Economic liberalisation and its attendant work restructuring have considerably transformed the traditional notion of formal economy work, dissolving the concept of full employment and the norm of the workplace as a space where a large workforce with clear relations with a common employer congregate. Employment is now concentrated in sectors of the economy with more diffused workplace and less clear identifiable employer. Employee/employer relations have become blurred with the recourse to precarious forms of work like labour casualisation through subcontracting, outsourcing and part/flexible-time work (Wood, 2004; RoyChowdhury, 2003; Lambert, 2002; MacInnes, 1990). The promotion of production and work forms like outsourcing, sub-contracting, part time labour, labour market flexiblisation has pushed the workforce to areas where collective organisation is difficult and trade unions coverage poor (MacInnes, 1990, p. 208; Harrod \& O'Brien, 2002; RoyChowdhury, 2003, p. 35).

Workplace restructuring impacts relations among workers and trade unions by fragmenting the workers and dissolving the traditional notion of work that underscores trade unionism (Wood, 2004). The ensuing labour variations are dependent on levels of employment protection. At the two extremes are workers with problematic trade union membership. They are the elite workforce at one end, and on the other, a large number of workers located within the informalised precarious sector. The elite category of workers, the 'cybertariat', possesses scarce professional qualifications that secure their jobs and conditions of employment. Elite professionals require no bargaining coverage. Their working conditions are directly tied to the survival of the organisations in which they work in ways that identify them more with owners than with their co-workers (Munck, 2002; Hyman R. , 1999). Workplace restructuring go hand-in-hand with the employment of the socially disadvantaged like women, racial minorities, children and migrants (Work, 2002, p. 10). There develops, as a result, labour markets where, according to Hyman, employment is more casualised, 'collective regulation ... non-existent' and employment situation quite precarious (Hyman R. , 1999, p. 104). This informal or atypical sector where employment seems to be growing does not lend itself to the development of work relations on which trade unionism is founded (Hyman, 1999, p. 100).

Unions have no appeal for the elite workers. The informalised workers are constrained by their vulnerability to join trade unions. Patterns of unionisation, according to Hyman, reflect the inverted $U$ curve: lowest at the extremes of highly educated, most advantaged workers and unskilled, insecure least paid workers. While high education and rare skills render unions protection irrelevant for the first cate- 
gory, low incomes and job insecurity prevent the second from building 'stable collective organisations' (Hyman R. , 1999, pp. 99-100).

Writers such as Hyman see the greatest threat to organised labour as deriving from workplace restructuring which affects employment survival and employee solidarity (Hyman, 1999). Union's role in interest representation faces new forms of challenges from management styles like employee involvement practices which emphasise mechanisms for controlling workers as individuals and not as a collective (Hyman R. , 1999, pp. 104-5). Employment relations between management and workers have been transformed into practices that appear to give individuals better place in employment decisions but in effect promote individual interest over the collective, thereby undermining trade unionism within the workplace. The stress is on the uniqueness of each individual worker and by that individualizing 'the nature of the employee-employer relationship'. Workers no longer have a collective workplace identity and lose a central organising moral i.e. a common interest shared by all within an enterprise (Work, 2002, p. 45). RoyChowdhury insists that new strategies which stress management/worker consensus by institutionalising workplace information sharing and employee participation do not operate within a framework that is empowering for workers and their organisations (RoyChowdhury, 2003, p. 38). The participatory practices, he explains, are produced within management defined structures that seek to protect the interests of the enterprise and not those of the workers. The practices are able to pre-empt conflict and allow the introduction of enterprise restructuring that erodes workers' rights while facilitating 'the process of production and the larger purpose of capital accumulation' (Fairbrother, 1990; RoyChowdhury, 2003, p. 44). Such practices destroy workers' sense of solidarity and group action (Work, 2002, p. 45). Work and employment restructuring 'fragments the terrain of collective action' within the workplace and the introduction of market principles into the workplace sets 'various sub-units' competing with each other (Hyman R. , 1999, p. 104).

Changes in work and employment relations have implications for the relevance and representativity of labour movements as employment opportunities in the sectors where they draw members keep diminishing (Work, 2002, p. 10). Such changes push workers into work areas out of the reach of unions, thereby reducing union density and representativity. The restructuring of the traditional workplace means that workers no longer relate as they used to. The production relations of these workers question the traditional foundation of trade unionism which assumed certain notions of workplace structure and relations. Workplace restructuring weakens unions by eroding the basis for collective action and individualising workers efforts at securing their employment (Munck, 2002). Utilising Muller-Jentsch analysis, Hyman identifies three types of crisis created by economic and labour market restructuring and the resulting workplace flexibilisation. The three are the crisis of interest, workers and union representation (Hyman R. , 1999, pp. 99-100). Employment restructuring by individualising workers undermines the sense of workplace 
solidarity on which unions are founded making unions irrelevant in the workplace, while unions are still grappling with strategies to effectively organise workers in the new forms of workplace created by globalisation (Hyman R. , 1999, p. 98). Ultimately globalisation reformulates production relations causing fundamental changes within labour markets and changing conditions under which work is conducted.

It is therefore not surprising that organised labour has been at the forefront of organised opposition to globalisation (Önder, 1998). Önder's account of history of economic restructuring in Turkey shows how the Turkish state incurred labour's opposition because economic restructuring set out to discipline labour in order to 'facilitate the international competitiveness of Turkish exports' (Önder, 1998, p. 51). As mentioned earlier, state and organised labour relations in Ghana were intensely acrimonious under economic restructuring. The challenge then is how trade unions devise strategies to combat the threat of globalisation to their very existence. Hyman believes a solution can be found in how unions reconfigure strategies that allow them to appeal to the categories of labour that fall outside their traditional operating terrain (Hyman R. , 1999, p. 100). Fairbrother contends that it is through the renewal of unions that pro-active forms of dealing with workplace and employment restructuring can emerge (Fairbrother, 1990).

The discussions of labour market restructuring are based on labour market scenarios of industrialised economies which tend to be highly formalised. The derived assumption is that the standard workplace is formal and labour form male. Formal workplace restructuring affects majority of workers. In developing countries such as Ghana, however, the dominant workplace is informal where females dominate. Trade unions have made various attempts at including such workplaces under their coverage. Labour market and workplace restructuring has impacted the already small formal sector reducing it to an even smaller fraction of its original self. There are indications that this sector stands to contract even further. The challenge for unions is what organisational form is relevant for deepening coverage in a manner that takes on board the peculiar circumstances of work organisation in all its forms as shaped by work and workplace restructuring. To propose possible approaches requires an understanding of how unions organise, how they obtain their motivation for organising and how they determine their functions and relevance to their membership and beyond.

\subsection{CONCEPTION OF UNION ROLE AND RELEVANCE}

Union functions and membership lie at the heart of its definition and conceptualisation. Definitions generally accentuate the core membership and functions of unions by emphasising the fact that trade unions act to defend workers' interests on several fronts. Definitions that highlight core union membership, according to Jelle, tend to be exclusionist restricting membership to workers and omitting employers and 
management (Jelle, 2003). Functional definitions usually highlight the economic, political or social roles of trade unions (Harrod \& O'Brien, 2002). Some of these definitions look to current functions. Others look to trends in union historical role in national politics. The manner in which unions are conceptualised is important for determining what they address as core responsibilities. For a more comprehensive view of trade union role and operations is the definition that conceives unions as constituting the accepted organisational mode for workers' interest representation institutionalised worldwide with specific rights and responsibilities (Harrod \& O'Brien, 2002).

The various theoretical traditions-the political economy, liberal economy, neocorporatist, Marxist and feminist among others-interpret union functions differently (Streeck \& Hassel, 2003). These traditions perceive union functions in terms of the members and other interests they serve beyond the workplace. The conservative traditions which underlie the economists' views explain trade unions as basically self-serving and acting to distort the labour market. This view informs the attitude of the World Bank to trade unions (World Bank, 2004). Political scientists devote attention to union political activities and how their alliances with other political agents, like political parties and civil society groups, further union interests (Streeck \& Hassel, 2003; Harrod \& O'Brien, 2002; Jelle, 2003).

Defining unions serves to verify their space and role in national development. Unions determine their functions from the way they conceive their roles and the constituency they serve. This shapes their ideological and political orientation, delineating the contours of their activities either as purely economic, political or both. Union ideological orientations are very similar to the theoretical orientations used to explain their behaviour. It is difficult to locate unions within one theoretical tradition for the reason that economic and political events that inspire union activities cannot be circumscribed to a particular realm. The distinction between economic and political interests of unions is usually tenuous. Political decisions at the national or even international level affect the economic environment in which unions operate. In the same manner economic policies have political ramifications. Union roles therefore span both the political and economic realms. The political roles of trade unions have varying importance in different countries and are very often subject to state control (Harrod \& O'Brien, 2002).

It is generally accepted that for unions to be effective, they have to be capable of furthering the interests of workers, both in the workplace and beyond, be part of activities that seek to transform society and offer support for society-wide norms of social justice (Fairbrother, 1990; Jelle, 2003; RoyChowdhury, 2003). Key factors that facilitate union ability to further workers' interests effectively are both internal and external. These include union national presence, internal democracy, bargaining coverage and workplace representation as well as public perception of unions (Jelle, 2003; Streeck \& Hassel, 2003; RoyChowdhury, 2003; Fairbrother, 1990). The size of 
union membership, its density and concentration as well as internal cohesion, grant unions a dominant national presence. Strong internal democracy and effective workplace representation improve union bargaining power. The simultaneous acquisition of all these features is dependent on union political orientation.

Union political orientation is shaped by its location within the production relations. Their likely concerns and historical origins are particularly important in determining the final nature of this political orientation. Unions have played different roles in the political histories of their countries. Whereas in Western Europe it was basically in the establishment of what is widely held to be the democratic state to replace the monarchy, in Africa, Asia and Latin America unions played significant roles in their nations' struggles against colonial rule and subsequently towards multiparty liberal democracies. The action of Polish trade unions, which led to the collapse of the socialist state and later triggered similar changes in the whole of Eastern Europe, is an example of union role in national political history in recent times. The same is true of trade unions in Africa (Kraus, 2007; Kester G. , 2007). Union involvement in the transformation or reform of their countries has been dependent on their political orientation or ideology.

The connection between union political role and status tends to be circular because the choice of union political activities is dependent on their political status which in turn affects the strategies they deploy to meet their political goals. The fact however remains that union ideology or political orientation directs their political choices in terms of their strategies and activities for furthering their aims. Unions have relied on political alliances with religious bodies or working class political parties to wage political struggles. Such alliances have determined how unions evolved in opposition to the modern state and their final political status (Streeck \& Hassel, 2003). In countries where unions have been active participants in the process of social transformation, they have been accorded special status within their nations. The ideologies underlying present international political economy however have undermined this political status (Harrod \& O'Brien, 2002). The conceptualisation of production relations and labour's role within current development discourse spearheaded, as noted, by the IMF, World Bank and the WTO, present organised labour as an obstacle to economic progress. Thus labour is presented as a problem both within national policy debate and at the workplace and as such has to be disciplined. Workers organisations then become irresponsible associations when they make demands for better worker welfare at the workplace and the national level (Harrod \& O'Brien, 2002, p. 28).

The ILO's core convention makes the right of trade unions to an independent existence a global issue in the same manner its 'decent work' programme allows the use of the concept 'social efficiency' to counter globalisation's insistence on economic efficiency (ILO, 2004). This ILO position, according to Munck, introduces an ethical debate into individual right to work and working conditions and the use of trade 
unions to protect this right (Munck, 2002, p. 186). ILO's work has given trade unions and workers' organisations legitimate recognition by asserting labour rights as a fundamental human right.

Union relevance extends beyond a purely instrumental or political function. Unions are important because labour involves human beings. The ILO insists that trade unions are necessary for they protect human beings as they engage in production and constitute important vehicles for the realisation of fundamental human rights. Debating the position of labour within globalisation, Munck cites Polanyi to explain that the protective function of trade unions and labour legislation is necessary in order to 'remove human labour from the orbit of the market' (Munck, 2002, p. 176). Munck utilises the social embedded hypothesis to explain why labour cannot be treated like a market commodity. The social, political, cultural, gender and moral relationships in which the workplace is embedded means that the workplace should not be 'subsumed within market categories' (Munck, 2002, p. 184). If the workplace operates within the social political cultural and gender networks of the broader community of life beyond then it presupposes that the labour movement arising out of workers' collective efforts should expand its operating terrain to cover issues confronting life in spaces beyond the workplace. For Munck this extension of interest is necessary not only because unions and labour movements are 'made up of... and ...create, a dense network of social relations' but more especially because labour refers to humans. Human labour cannot be treated as any commodity. It therefore behoves that institutions that protect it should function effectively to undertake their responsibility.

Union value is not in question. What is at stake is how unions determine their functions and the strategies they adopt to pursue the functions once defined. Beyond dwindling membership, unions have to deal with the question of relevance and representativeness in their quest to provide adequate protection for their members in the face of workplace management and new forms of work created by globalisation (Munck, 2002, p. 185). The scope of union activities allows unions to embrace a range of issues that will increase their effectiveness and relevance. However, charting union scope of activities is ideologically derived: first, by the unions and secondly, by other actors within the society in which they operate. How unions are conceptualised therefore becomes an important tool for strengthening their chances of remaining relevant and effective in their primary function of defending workers.

\subsection{ORGANISED LABOUR RESPONDING TO GLOBALISATION}

In the face of intense challenges imposed by globalisation, unions have had to develop strategies to ensure survival and secure their relevance as organisations for advancing the interests of working people. A variety of terms like renewal, revitalisation, rebuilding, rebirth, revival, resurgence, reinventing, rekindling and transformation are used to refer to the numerous actions that labour have taken to adjust 
to fundamentally altered external environment to strengthen themselves in the face of their declining role and influence in the workplace and society (Kumar \& Schenk, 2004). Fairbrother for example uses the term union renewal to describe this process where unions 'reorganise and recompose themselves' to meet new labour market challenges by re-conceptualising their core functions (Fairbrother, 1990, p. 151). For Turner the final outcome of revitalisation is the ability of trade unions to influence contemporary developments (Turner, 2004). The process and content of revitalisation is important for successful outcomes if unions are to maintain their relevance and effectiveness.

Variations in outcomes of union strategies continue to fuel interest in union renewal studies about the choice of strategies to reverse membership decline and improve union political power. Munck adopts Tilly's notion of 'labour repertoires' to describe the process by which union strategies are developed. Labour repertoires, the process by which unions 'develop ideas and take action,' he explains, are 'set by objective conditions' which can be both internal and external (Munck, 2002, p. 164). While some have claimed that forces external to unions are key determinants, others rather look within unions to identify motivating factors (Behrens, Hamann, \& Hurd, 2004; Kelly \& Frege, 2004; Streeck \& Hassel, 2003; Munck, 2002; Hyman, 2001b; Steele, 1990).

Frege and Kelly in their summary of existing literature on determinants of union strategies have categorised external factors as path dependencies and identified industrial relations institutions like collective bargaining structures, labour legislation regimes and corporatist institutions as well as state and employer organisations (Kelly \& Frege, 2004). The political or economic conditions at the workplace, or beyond also play a key role in the determination of labour repertoires.

Unions have usually mediated the impact of external conditions by adopting strategic partners. Lambert for example, insists that the eventual content of union response (repertoire) to globalisation is directly influenced by their choice of strategic partners (Lambert, 2002). Strategic alliances with the state, political parties, religious bodies, civil society groups and other labour movements have facilitated the development of labour repertoires and final union strategies. The emerging strategies have shaped the eventual forms in which unions have evolved during renewal.

Examining union strategies through their choice of allies, Lambert conceives of two main models of unionism, movement and business unionism, each occurring in two variants. A variation of movement unionism is political unionism where unions enter into partnership with political parties. The other variant is social movement unionism which involves union alliances with civil society groups (Lambert, 2002, p. 189). Business or economic unionism results from an attempt to align union interests with enterprise goals. One variant is best practice or strategic unionism which is the outcome of unions adopting practices they conceive as sound for increased pro- 
ductivity. The other variant is authoritarian unionism, which results from employers imposing their terms and conditions on unions.

Unions have also relied on other unions to increase their influence and enhance their effectiveness. Global union alliances have constituted important repertoires in labour's response to globalisation challenge. Such global alliances according to Munck, have usually taken three forms - company-wide support for a subsidiary in a country dispute, 'multiple negotiations with the same company located in several countries at the same time and integrated negotiations around common demands across a multinational' (Munck, 2002, p. 145). Such collective and solidarity actions by workers' movements of TNCs in several countries represent an effective strategy that unions can utilise to deal with globalisation. They are particularly effective for neutralising 'race-to-the-bottom' policies.

The extent to which coalitions can grant unions autonomy and transform working relations to the benefit of workers depends on their orientation as business or movement unionism. Business unions are likely to choose as coalition partners, employers or political parties. Strategic alliances, be they political or economic, have always been fraught with risks for union effectiveness and representativeness. The dangers have either come out of pressures for unions to surrender their autonomy, sacrifice some interests or have their political agenda derailed. Business unionism for example is a catch for complete subordination of workers' interests. In accepting to cooperate with management for the efficient functioning of the enterprise, to maintain 'international competitiveness', unions discard the ideology of exploitative relations within the production process and place workers' interests at par with enterprise efficiency (Lambert, 2002, p. 187; RoyChowdhury, 2003, p. 46). Business unionism depoliticises trade unions. Authoritarian unionism, the most dominant form at present, especially in Asia, is eroding completely whatever power trade unions had in the workplace (Lambert, 2002, p. 194). Political unionism can also render unions apolitical. Union leaders in response to pressures from employers and government, attempt to emphasize their competence and expertise by adhering to the rules and procedures for negotiation and consultation (RoyChowdhury, 2003; Fairbrother, 1990). Using the concepts 'bureaucratisation and 'routinization' of bargaining arrangements, Fairbrother explains how, in the process of re-conceiving their core functions, unions can become fixated on procedures and rules. The attendant 'professionalisation' of bargaining arrangements leads to a de-linking of enterprise level concerns with national political issues and therefore a de-politicisation of trade unions (RoyChowdhury, 2003; Fairbrother, 1990). The tendency is for depoliticised union leaders to see themselves more as professionals with defined enterprise level commitments and less as union activists. Such leaders are not interested in operating a movement with an active rank-and-file whose concerns are connected to a broader political agenda (RoyChowdhury, 2003, p. 46; Fairbrother, 1990, p. 161). The choice of strategic partners therefore is important for ensuring successful revitalisation outcomes because they determine where membership con- 
cerns sit in the rules for maintaining alliances. Forms of unionism which are dependent on union choice of strategic partners affect union renewal strategies.

The internal factors which come to play in discussions of union renewal strategies revolve around democracy, ideology and union identity. Some effort is devoted in revitalisation studies to unravel forms of union identity and how they are developed. Streeck and Hassel, for example, state that union political behaviour which is the outcome of its identity as reformist or radical, are shaped by the class system before industrialisation. The response of the political elite to workers' demands for economic or political participation affects union identity (2003, p. 337). For Hyman, union identity, which is shaped by its orientation towards class, market or society, is the key factor that points out strategy choices and possible actions (2001b). Steele, (1990) believes that union heterogeneity determines strategic choices and outcomes. The strategies chosen and their outcomes are determined by what groups or factions within unions perceive as a potential threat to their interests. Lambert insists that union form is shaped by its choice of strategic partners (2002).

Strategies unions adopt to meet their goals derive from their ideological perspectives which ideology in turn determines union functions. The confines of union concerns which are shaped by their ideological orientation direct their choice of strategies. As Fairbrother explains, determining the confines of union concerns, either within enterprise or broader national and international political economic scene, is an approach that unions have taken to address the conditions in which they operate. Union functions shape their aims and the means they adopt to achieve their aims.

Union strategies have implications for union survival in that they underpin union democracy. Democratic issues within union strategies encompass issues like union operating terrain, the room strategies offer trade union members to equally participate in union activities and the extent to which the interests pursued within specific strategies are truly representative of the concerns of the entire membership (Cook, Lorwin, \& Daniels, 1992). Union democracy is contingent on the scope of their political agenda and capacity to encompass issues outside the workplace and still impact workers and their working lives. This suggests a close relationship between union identity, ideology and internal democracy. The question is which ideology allows unions to develop strategies that are capable of taking on board the peculiar interests of all categories of members in the workplace and beyond.

Unions' political outlook or ideological orientation sets limits to their operating terrain and final choice of strategies, deciding whether union activities will stop at workplace concerns or extend beyond to embrace wider social issues. Models of unionism suggest differences in union ideological orientation and interpretation of working conditions. Forms of unionism provide the opportunity or otherwise to identify what issues in workplace to cover (Cook, Lorwin, \& Daniels, 1992; Curtin, 
1999). Political unionism and transnational collective bargaining expands unions' operating terrain conceptually and spatially. Business unionism restricts union strategies. Political and transnational unionism also allows unions to highlight exploitative relations between workers and employers. Both Curtin and Fairbrother believe that it is only through broadening their political agenda that unions can take on board a wider range of membership interests (Curtin, 1999; Fairbrother, 1990). Fairbrother warns that the dislocation of individual worker's interests from broader national or even global social political and economic environment can lead to a weakening of trade union political relevance and therefore power. For him, 'the vitality and innovativeness of the working class is rooted in the contradictory experiences of work and community, between the pressures that underwrite individualism on one hand and collectivity on the other' (Fairbrother, 1990, p. 174).

Lambert contributing to the debate on the role of labour ideology in fashioning an appropriate labour response to globalisation, observes that current labour movements, having suffered extensive membership decline in the 1980s and 1990s, appear to be in some 'ideological disarray' (2002, p. 185) and have lost the earlier dynamism of trade unions at the turn of the twentieth century that linked workplace struggles to longer term social change. Discussing the impact of labour market restructuring in India and organised labour's response, RoyChowdhury confirms the importance of a coherent union ideology for the development of effective strategies to counter the effect of globalisation (2003). The lack of a consistent and coherent union ideology limits the ability of unions to critically analyse globalisation as a labour exploitative political and economic system leading unions to accept the negative impact of globalisation as given (Lambert, 2002, p. 186).

In their discussion on British unions, Streeck and Hassel (2003) explain that the failure to develop a coherent socialist ideology on the part of British unions led to a low degree of politicisation which in turn protected them from political splits that characterised other European unions. In addition, British unions limited their struggles to collective bargaining and state provisioning of social wages premised on cooperation with the state. But this approach did not offer protection to British workers even though it prevented an eventual splintering of the union. When global economic ideology made provisioning for workers' welfare and company survival mutually exclusive, British workers were not spared the brunt of labour market and workplace restructuring and attendant trade union membership decline. The role of union ideology in shaping union strategies requires further examination. It is clear that union ideology directs union political agenda and determines what space within national political arena unions occupy.

Kelly and Frege however feel that internal or external conditions of unions alone do not offer sufficient explanation of how unions arrive at their choice of strategies. While dismissing path dependencies as simplistic and deterministic because they downplay the mutual dependence between various industrial relations actors, they 
feel that an exclusive focus on union identity does not allow sufficient space to interrogate how other factors or actors shape union identity (Kelly \& Frege, 2004). A good approach for investigating determinants of union strategic choices, they insist, should proceed from how a combination of union internal and external factors account for the mix of union strategies and the varying successes chalked by unions in their journey towards revitalisation. Munck affirms the notion that a combination of factors account for the choice of union strategies (2002). This suggests that external factors shape the internal conditions of unions and produce some cyclical relations between union identity, ideology, strategic choices and outcomes. Thus, union shape and ideology determine strategies adopted; but these strategies also in turn shape the eventual forms that unions adopt.

The numerous strategies devised by labour movements to maintain their relevance and ensure survival have impacted union internal democracy in that membership interest then tend to diverge. Strategies can be undemocratic if they are based on fixed patterns of representation which tend to exclude certain categories of union membership like women, low income and migrant as well as informal economy workers (Curtin, 1999). Determining a collective interest for unions to pursue can be problematic since the determination of union collective interest is predicated upon a process Curtin identifies as the homogenisation of the heterogeneous demands of workers. The concerns of peripheral members often get subordinated (Curtin, 1999, p. 21). The outcome of union activities, depending on the ideological orientation informing the strategies utilised, offer differential benefits to its members, with some losing out completely. Determining membership interests calls for contestation and negotiation involving power struggles within unions as established membership groups struggle to dominate their unions.

Contrary to predictions of their eventual extinction, there has been renewed growth among unions. Union survival underscores their relevance and effectiveness in protecting workers in the face of intense hostility. Despite their ability to survive, unions still continue to grapple with challenges that undermine their relevance and existence. Studies on union revitalisation or renewal, however, have concentrated on unions in the industrialised world of Europe, the US, Japan and Australia (Brueggemann \& Brown, 2000; Kelly \& Frege, 2004). Notable exceptions have been Önder's work on Turkey and RoyChowdhury's on India which have shown how unions have fared in the face of economic adjustment and hostile labour policies from the state (Önder, 1998; RoyChowdhury, 2003). What these studies have revealed is the importance of the ideological orientation of union actions on the direction of their strategies and how union ideology impacts internal democracy. This makes it clear that union renewal strategies have a direct implication for internal democracy.

Much effort has been expended on determining how unions define their strategies and the corresponding ideology shaping labour repertoires. The implications of 
renewal strategies for internal democracy which requires a more critical engagement if union revitalisation is to enhance union legitimacy and effectiveness has not attracted a corresponding attention. It is not too clear which successful renewal strategies are sustainable and which ones serve the interests of the heterogeneous union members equally. Similarly unclear is the framework for explaining the forms of internal dynamism generated within unions by the varying mix of renewal strategies and their supporting ideologies. Finally and more importantly is the implication of such dynamisms for internal democracy.

\subsection{COLLECTIVE ORGANISATION AND INTEREST REPRESENTATION}

Discussions on union democracy usually devote attention to membership and leadership relations. The relationship between unions and their members is seen as being essentially underlined by the extent to which leaders seek the interests of members and how sectional interests within the trade union movement are represented. Attempts to understand how unions evolve the interests they pursue have yielded different opinions depending on the theoretical perspective used to analyse unions. Heery and Fosh (1990) explain that most of these accounts argue that union leaders or bureaucracy develop interests that are separate and opposed to those of their members. Intra-union conflict and membership dislocation is generally blamed on the inability of union leadership to align its actions with the interests of their membership especially in instances where they make concessions in bargaining with employers or with their political partners.

The position that a gulf exists between membership and leadership interests is widespread and the ensuing debates are as old as unions themselves. There is also the idea that unions are incapable of being truly representative of membership interests since workers do not constitute a homogenous group (Curtin, 1999). Union choice of interests determines who they serve and how democratic they are (Heery \& Fosh, 1990; Undy \& Martin, 1984). The concept goal convergence or divergence is used to explain the intra-union tensions that erupt as union leaders and members attempt to evolve common interests. There is union goal convergence if the interests leaders pursue coincide with those of the majority of members. Otherwise union interests diverge. The various models of trade union democracy locate possible sources of goal divergence within the choices pursued by union leadership or 'bureaucracy', the 'guardians of the unions', and the perception of union membership of the utility of such policies to their welfare (Heery \& Fosh, 1990, p. 23). Leadership has to ensure that members accept the outcome of their negotiations or even before negotiations, insist that members give up claim to certain demands in order to increase the chance of obtaining certain benefits. Such compromises are not easily reached between members and their leaders. Tensions developing between members and leaders are represented as centred around diverging union interests. 
Studies devoted to understanding union leadership and membership relations have been greatly influenced by Michels' iron law of oligarchy (Undy \& Martin, 1984, pp. 189-190). Michels contends that by adopting an organisational form, representative bodies like trade unions grow to become oligarchic (Michels, 1959). According to Michels the organisational form, an important structure for representative groups to realise their goals, is fraught with dangers that derive from the bureaucratic structures set up to maintain them. One such system is the need for delegation of group power to elected representatives through the election of officers to lead the organisation. By the nature of leaders, members and the logistically cumbersome procedure of promoting direct democracy, the leaders chosen by members to be their representatives, soon become a class onto themselves, completely out of the control of members and removed from their reality (Michels, 1959). In fact Michels is sceptical of 'permanent representation' and believes that it 'will always be tantamount to the exercise of dominion by the representatives over the represented' (Michels, 1959, p. 40). The cause for this can be found in human nature, weaknesses on the part of both the led and leader. Michels has no faith in the ability of organisations to promote democracy. As far as he is concerned democracy can only be a means and not the end. All organisations can do is to fight to attain democracy $(1959$, p. 86).

The tendency on the part of leaders to be oligarchic in representative organisations, Michels affirms, is higher in trade unions. The gulf between leadership and membership widens as leaders become more fixated on ensuring organisational survival and become apolitical. Leadership turnover is limited, union goals turn conservative and their tactics non-confrontational (Voss \& Sherman, 2000, p. 309). Such unions, designated as service unions, concentrate on servicing their members (ibid). Thus in their mature state organisations become oligarchies. The tendency to be oligarchic is both humanly and institutionally embedded. Michels states that ' $[t]$ he apathy of the masses and their need for guidance has its counterpart in the leaders, a natural greed for power' (Michels, 1959, p. 205). The organisational structures combined with human nature promote oligarchy and in no time leaders operate organisations for their benefit. Michels' iron law insists that union leadership and membership goals will diverge as unions mature, become more bureaucratic and less political.

Not all traditions explaining internal union behaviour however believe that there is a problem of converging union goals or interests or that union leadership has the tendency to pursue its parochial interests. Addison and Schnabel, examining the debate within the various scientific orientations explaining union behaviour, note that pluralists contend that unions are relevant for promotion of workers' rights in the work place (2003). Heery and Fosh also reinforce this claim by emphasising that unions actually advance the genuine interests of their members and other members of the working class (Heery \& Fosh, 1990, pp. 2-3). While employers and employees have a common interest in the survival of the enterprise on which they are both dependent, employers cannot constitute reliable promoters of employees' interests. 
In the first place, the two have irremovable divergent interests expressed in conflicts over pay, staffing levels, work intensity and supervision (Heery \& Fosh, 1990, p. 3). Secondly the collective organisation of workers poses a useful counterbalance against the power of employers that allows workers to sustain meaningful collective bargaining for advancing their interests.

Pluralists reduce internal union politics to a continuous struggle between union leadership desirous of maintaining orderly exchange between their unions and the traditional alliance partners and factions within the membership whose interests are compromised in the exchange. The effort by union leadership to ensure that their members accept agreements reached with external partners is described as exercising leadership or enforcing discipline. Heery and Fosh suggest that union leaders enforce discipline on their members to accept the outcome of their negotiation with employers or governments (Heery \& Fosh, 1990). Union democracy in this instance is equated with 'responsible union leadership', that is leadership efforts at ensuring membership compliance with negotiated outcomes or moderating workers' demands in order to ensure successful negotiations. Streeck and Anke (2003, p. 337) identify corporatist collaborations between union and government as a significant source of union political strength. The functional representation of unions on parastatal institutions and governance structures, like social security or labour market together with employers and government officials have resulted in the erection of social security systems to support working life. But these political gains come at a cost to union internal democracy.

Political economists identify a possible 'crisis of representation' within unions because members are required to make sacrifices to sustain the outcome of some exchange with external partners. The direct worth might not be immediately clear to union members since such corporatist exchanges are normally for social wages and sometimes far removed from the workplace. Feminists identify a divergence in the goals pursued by trade unions and the concerns of their female members. Women face a double labour market disadvantage in terms of the nature of their employment and the conditions under which they work. Male dominated trade unions, by accepting the existing sexual division of labour that projects the worker as male with a dependent wife and children in collective bargaining, defend the interest of male workers. In so doing they promote patriarchy and only serve to reinforce the double disadvantage of working women (Streeck \& Hassel, 2003, p. 13).

Marxists and Conservatives contend that union leaders have structurally distorted union goals and betrayed their members but for different reasons. Marxists locate goal divergence within the institutional distance between union leaders and members. In the first place union leaders enjoy middle class working conditions, which are sheltered from the exploitative and precarious conditions of the majority of workers who make up their membership. The life style of union leaders is therefore a far cry from that of their membership. Secondly there is the tendency for a gradual 
reform of union ideology to uphold the notion of a neutral state. Quoting Hyman, Heery and Fosh note that because union leaders become preoccupied to 'cultivate the good will or at least acquiescence of employers and the state' they are compelled to recognise the rights of capital' (1990, p. 23). This modification of union objectives yields two results. The first is a moderation of union goals to allow room for negotiating improvements in the living standards of workers and the second is a surrendering of unions to the influence of external forces. When unions limit their activities to satisfying economic objectives, institutional survival and stabilising the relations between their members and their employers, they abandon wider political goals. Unions in this situation no longer serve the interests of their members (Addison \& Schnabel, 2003).

Conservatives believe that any union activity that extends beyond collective bargaining to include political interests of the working class, like challenging the existing economic order, is unrepresentative of union interests and distorts the real purpose of trade unions (Addison \& Schnabel, 2003). Goal divergence in unions results from an infringement on individual membership rights by their unions. When unions insist on promoting collective interests they invariable infringe on individual members' rights. By adopting an adversarial model of industrial relations practice, the relations between unions and management are reduced to relations of continuous conflict. Within unions, individual members stand alone and their wishes as individuals have to be upheld over the collective union goal (Heery \& Fosh, 1990; Streeck \& Hassel, 2003).

Suggestions for converging union membership interests look either to strengthening members or redefining union ideology. Generally conservatives, Marxists and feminists believe in strengthening membership control over their leaders. Conservatives insist that building more democratic unions depends on the amount of control members as individual or factions can command. They believe that by providing individual union members greater participation in union decision-making, organising opposition groups within the membership to exert pressure on leadership, unions are more likely to pursue membership interests (Streeck \& Hassel, 2003). Thus for conservatives, greater union democracy is achieved when individual members interests are not submerged within the collective interests, an idea underscored by British labour legislation during the Thatcher administration in the 1980s. Legislative instruments were introduced to grant trade union members direct participation in union decisions like whether or not to embark on strike. British trade union members were also by law provided assistance to pursue grievances against their unions (Undy \& Martin, 1984).

While conservatives suggest promoting individual rights, corporatists just like feminists advocate the promotion of sectional interests. Quoting Hirschmann, Undy and Martin, propose that union leaders should develop sectional 'loyalty' within their movements by deliberately matching union policies more closely to the con- 
cerns of sections of the membership or mobilize membership support for their objectives. Other options suggested include granting members who disagree with union policy the opportunity of a separate existence from their unions (Undy \& Martin, 1984). Feminists' suggestions to reduce union goal divergence aim to the shift the balance of influence within unions away from men and towards women. The strategy, called 'feminising of unions', seeks to change union governance structures to enable women achieve positions of power while at the same time raising the general level of women's participation in union activities (Heery \& Fosh, 1990). Such discourse appears to suggest that unions are truly representative of all male workers' interests and that only women's interests are unprotected. But as the debate has shown there is considerable disagreement about the extent to which trade unions serve the interests of all the workers they purport to represent. The underrepresentation of female members though is one of the clear examples of how the needs of sections within the trade union membership are neglected if such groups remain outside union decision/policy making.

The debates around goal convergence or divergence between union leaders and members as an indicator of union democracy have their limitations even though they point to important areas of intra-union friction. First, membership and leadership goals do not necessarily diverge always and intra-union power game is influenced by internal and external factors as well as union ideology. The critical factors that influence the adoption and implementation of union policies lie beyond the capacity of members to hold their leaders to account or the ability of the leadership to ensure that members accept the outcome of their negotiations. Leadership and membership preferences can vary widely but do not always diverge (Heery \& Fosh, 1990, p. 23). Using a pluralist analysis based on the assumption that there are major differences in perceptions of union goals among union leaders, activists and members, which are articulated through the union political system, Undy and Martin explain that occupational, industrial and ideological bonds sometimes override sectional interests (Undy \& Martin, 1984, p. 189).

A better way to conceptualise trade union relations with membership, Heery and Fosh recommend, must begin by looking for answers to the question of how and why the relationship between unions and their members varies in time and place. Factors dictating internal trade union behaviour originate from two locations: first within the trade unions themselves and, secondly, from the external political and economic environment in which trade unions operate. Internal factors derive mainly from the internal divisions within trade unions where workers are divided by diverse competing interests (Heery \& Fosh, 1990; Hyman, 1999). The first line division is hierarchical: union leaders or bureaucrats as against the sectional interests of members or the rank and file (Heery \& Fosh, 1990). The other is horizontal as revealed in the heterogeneity among workers. Hensman, exploring diversity in trade union membership in India, notes that different forms of inequality impact how workers are organised into trade unions and this in turn affects their participa- 
tion and representation (Hensman, 2002). Gender differentiation is one such ordering. The male character of trade unions leave women members alienated from mainstream union activities. Other lines of horizontal divisions derive from labour market inequalities that have accentuated differences in the workplace among workers like the formal informal economy divisions. The conclusion is that trade unions have uncritically absorbed existing social stratification into their structures and operations and tend to have different relations with individual members (Ledwith, 2006; Hensman, 2002).

Internal union behaviour is heavily influenced by external factors such as economic circumstances at the enterprise and national level (Undy \& Martin, 1984). Governments and employers who always have a vested stake in union matters initiate attempts to influence the outcome of union decisions and actions. Streeck and Hassel conclude that goals of trade union become misappropriated and union internal structures shaped to suit external interests in a situation where governments or corporations, under the guise of making trade unions more democratic, utilise legislation or workplace practices to alter union rules (Streeck \& Hassel, 2003, p. 218; Poole, 1981). Unions therefore should be viewed as complex political systems with a wide range of competing interests, both within and between the ranks of officialdom and the wider membership as well as their external environment (Heery \& Fosh, 1990). Hyman, who is very dismissive of corporatism between unions and employers, emphasises the importance of dialogue 'within and between trade unions themselves' (Hyman R. , 1999, p. 112). Hyman suggests that the way out for unions is a redefinition of the traditional functions of trade unionism in ways that provide an appeal to the 'diverse constituencies' of workers (Hyman R. , 1999, p. 111). This redefinition, he emphasises, must be connected to a reformulation of the 'how of trade union representation which allows unions to assert the rights of labour against capital's dominance (Hyman, 1999, p. 111).

The significance of these observations is that the tensions within unions cannot be reduced to those between union bureaucrats and membership. A more rewarding study of union politics must look beyond possible discord within the institutional interests of union officials and membership needs. Internal factors alone do not shape union behaviour; external factors are just as important. The impact of external forces on unions is invariably mediated by internal forces since the response of unions to government and employer pressures depend on the existing balance of power within the unions and the preferences of those who control policy (Heery \& Fosh, 1990).

Poole's concept of 'interest mediation' helps to explain intra union power game that comes to play in the process of evolving union interests (Poole, 1981). Intra union power game is influenced by union ideology which shapes the delineation of union operating terrain, restricting it to the confines of the enterprise or expanding it beyond to embrace wider social issues. RoyChowdhury describes union leaders who 
conceive of their roles within the limits of the enterprise as professionals. For such leaders, success will be equated with their ability to deal with firm level issues (2003). Leaders become political activists when they extend their activities beyond the firm. Union ideology is shaped by their historical origins and contemporary environment in which they operate.

While union interest mediation suggests a struggle around evolving union interests, Hyman proposes that deliberate attempts can be made to negotiate differences in union interests. He captions this process 'union solidarity'. He explains that it consists of a 'project to reconcile differences' in interests, and offer support and assistance to the claims of groups and individuals irrespective of immediate advantage in respect of one's own circumstances' (Hyman, 1999, p. 98). The need for union solidarity becomes imperative because of the variations among workers which produce conflict in terms of whose interest dominates union actions. Attendant to the heightened heterogeneity among working people are management practices that emphasise individualism as a conduit for employment success. The differences among workers undermine union solidarity and weaken union collective action for better living and working conditions (Hyman, 1999, p. 99). Hyman, in his examination of the impact of globalisation on union solidarity, questions if worker unity is achievable and if unions as currently constituted stand in a good position to attain worker solidarity. For him the problem derives from the fact that workers are divided by diverse and competing interests (Hyman, 1999, p. 94).

In debating the notion of solidarity within unions, he isolates two conditions: unifying sense of a common interest and purpose and consciousness of 'distinct and particularistic circumstances' (Hyman R. , 1999, p. 96). For him, however, a unifying and homogeneous notion of interests existing among workers or members of trade unions is illusory. Firstly, the manner in which unions are organised, while creating a sense of solidarity, can be dis-unifying. In demarcating membership, unions erect boundaries, what Hyman calls 'frontiers of exclusion', because the 'perceived common interests of the members of a particular union (or confederation) are defined, in part, in contradistinction to those of workers outside'... in compartmentalizing workers unions traditionally have compartmentalized solidarity' (Hyman R. , 1999, p. 96).

At the heart of union solidarity are issues of how common interests are defined how union profile is representative of its direct members and the general collective of workers on whose behalf they speak. The task of defining union interests, according to Hyman, involves tradeoffs, on one hand, between workers and their employers; and on the other, among the workers (Hyman R. , 1999, p. 97). The processes of defining interests within workers' movement have largely been determined in favour of a particular section of the working class. For Hyman, the class of workers whose interest directs union action is just as important as the type of interests that 
are relevant for union representation and bargaining policy; for these are the factors that determine what issues are 'union relevant' (Hyman R. , 1999, p. 98).

Unions have had to make choices to ensure survival and acceptability. Corporatist's collaborations between unions and corporations, governments, political parties or religious bodies, for example, have been one such choice. At present, unions are seeking to expand their membership and building inter union alliances nationally and internationally. Attempts to promote greater internal unity or solidarity, as Hyman prescribes, do not appear to receive the same attention within studies on union renewal or revitalisation strategies. Rather it has been Michels' deterministic iron law that has dominated. Michels' iron law suggests that no matter what structures are set up, representative institutions will always lend themselves to oligarchy incapable of supporting democracy. The perception that all organisations, in their old age, are incapable of transforming into democratic institutions is damaging for trade unions. If the iron law holds then trade unions are incapable of transformation to meet the challenges of globalisation. For globalisation and the problems it poses for organised labour can be met only through change in union tactics that draws more on membership involvement and less on leadership action. Another consideration for meeting the globalisation challenge is how unions evolve appropriate structures for mobilising informal economy workers and keeping their movements vibrant and relevant to their needs. Fortunately union's ability to reinvent itself suggests that it is capable of surmounting oligarchical tendencies.

Present works on trade unions have tended to shift away from the internal dynamics of unions to explain union behaviour and look more at how unions are strategising for survival (Turner, 2004; Kelly \& Frege, 2004; Voss \& Sherman, 2000). They are more concerned about internal and external factors that inform strategic choices and the content of such choices. The outcomes of strategic choices have their own implications for union internal democracy and have further importance for renewal outcomes. For it is clear that unions are themselves composed of competing interests and forces, largely as the outcome of the structure of the labour market and forms of existing social stratification with which people enter the place of work. These are factors further mediated by the tensions produced by capital and its representatives to control and direct union actions.

\subsection{UNION RENEWAL STRATEGIES AND INTERNAL DEMOCRACY - A CONCEPTUAL FRAMEWORK}

Dominant traditions in trade union studies focus on the 'transformation of industrial relations' and 'varieties of capitalism', with the latter building on the former to explain the variations in union operations under different industrial relations systems of capitalist countries. These two approaches, according to Turner, which focus on institutional configurations and bargaining relationships of trade unions, are limiting in terms of scope and subject, for they focus on industrialised capitalist 
societies and assign union strategies a secondary place (Turner, 2004). He believes, however, that there is the need to account for proactive attempts by unions to influence contemporary developments that affect their relevance and effectiveness. Likewise Frege and Kelly, (2004) dismiss theoretical orientations restricted to explaining actor strategies or their institutional context as 'too simplistic and deterministic' and insist on the need 'to trace out the reciprocal interconnection between the two' (Frege \& Kelly, 2004, pp. 38-39).

Union revitalisation is labour's response to globalisation challenge of work and employment restructuring. Frege and Kelly, offer an important framework for categorising union strategies and the direction of their content. Behrens et al however believe that it is not enough to understand forms of union strategies and how they boost membership but to understand how these strategies interact (Behrens, Hamann, \& Hurd, 2004a). Explaining that union activity is multi-faceted, they conceive that unions are capable of deriving power from the various spheres in which they engage. As a result, they state that 'union revitalization can be conceptualized as (re)gaining power along the various dimensions that capture the main orientations or spheres of union activity'. They specify four dimensions of union revitalisation three of which they derive inductively: 'the membership dimension, the economic dimension and the political dimension as those that capture most clearly the different patterns of crisis and renewal'; and 'add a fourth, institutional dimension, designed to encompass unions' internal structure, dynamics, and identity' (Behrens, Hamann, \& Hurd, 2004a, p. 20). They also agree on the interconnectedness of union choice of strategies, revitalisation dimensions and spheres of union activity as outlined by Hyman and contend that revitalisation can only occur if it is secured with fundamental changes in the institutional dimension. Institutional dimension, they explain, refers to the response of union organisational structures, governance and internal dynamism to revitalising strategies as well as a reshaping of union identities and goals to redefine their social, political and market roles (See figure 2.1). 


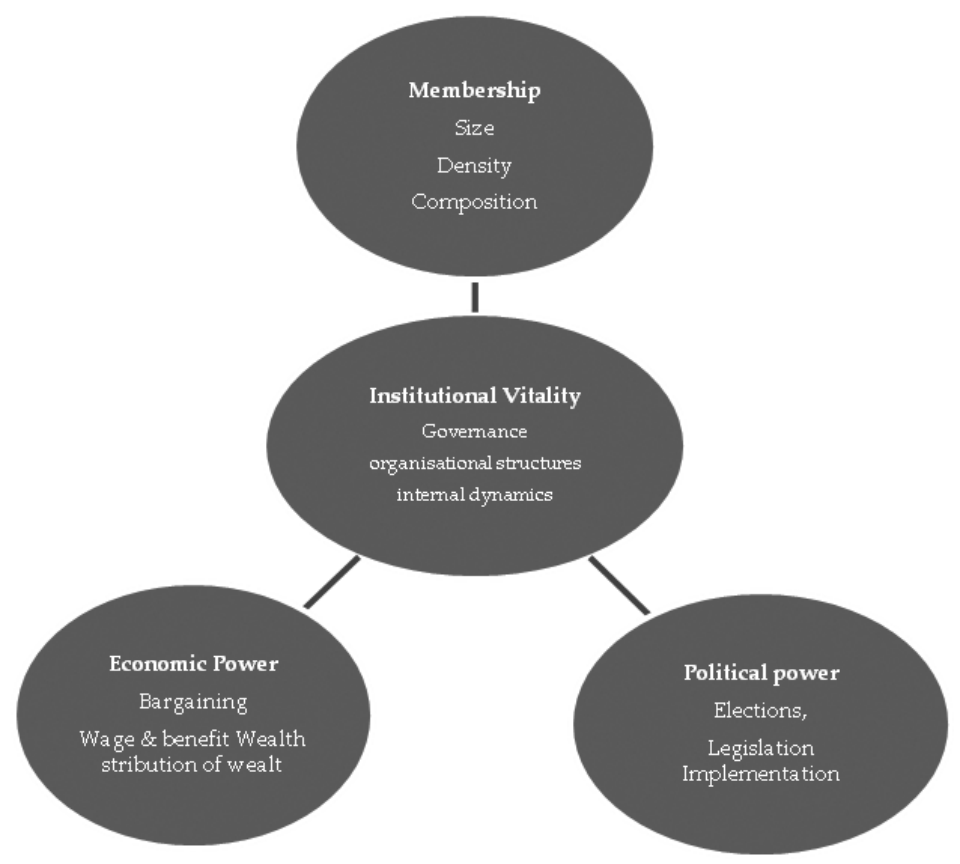

Figure 2.1 Dimensions of union revitalisation.

Source: Behrens et al, 2004

Successful revitalisation along the membership dimension translates into expansion in union size, density and composition to enhance union resources and mobilisation base. Economic dimension covers union bargaining power and impact on the distribution of wealth (Fig 2.1). The avenues for achieving union economic power include, bargaining and non-bargaining corporatism, reforming and redefinition of the bargaining process. Union ability to engage policy underscores revitalisation along the political dimension. It calls for union interaction with crucial national and supra governing political actors in three important spheres of political activity: elections, legislation and policy implementation. They fall on organisational theory to understand the internal dynamics that prevent unions from rapid internal adjustments to new circumstances and union apparent reluctance to revitalise along the institutional dimension by reforming their identity and structure, (Behrens, Hamann, \& Hurd, 2004a). They use the organisational approach to account for both internal and external factors shaping the dimensions of revitalisation that unions target. Both union leaders and members are assigned some agency in the determination and shaping of renewal strategies as well as its possible outcome. This agency however is more dependent on leadership strategic choice than members' interests. The space given to union leadership in the determination of union internal vitality derives from the dependence of the dimensions of union revitalisation on social 
movement theory that give centre stage to union identity as shaped by the 'collective world view of union leaders' (Frege \& Kelly, 2004, p. 39). Their final conclusion is that even though several factors account for union choice of strategies, unions, especially their leaders, have some leeway in determining the list of strategies and, in addition, space to influence union members.

However in the determination of how the internal dynamism of unions are shaped and reshaped by revitalisation, it is important to go beyond Frege and Kelly's rendering of unions as institutions with actor status; and define them as class based organs under continuous restructuring by capitalist production forms. The dimension of revitalisation is important in terms of how it makes the connection between union renewal and the underlying questions of internal democracy. Its reliance on organisational and social movement theories however tends to de-emphasise the connection between union internal democracy and class based struggles of workers and their union movements within capitalist production relations. Union institutional vitality is about internal democracy. After situating union internal democracy within the process of union revitalisation along with the dimensions of revitalisation framework, it becomes necessary to answer the question as to how union internal dynamism becomes a site for the struggle of workers against capitalism.

As explained earlier, there are various renderings of union internal democracy either as leadership accountability or control or membership representation. For Flynn et al, the debate on union democracy is both analytical and ideological, compounded by a confusion of what purpose union democracy should serve (Flynn, Brewster, Smith, \& Rigby, 2004). Hyman has also raised a similar point, giving representation greater importance than participation. As they explain, conceptualising union internal democracy around representation or participation has several implications. First, the two are in practice difficult to separate since voice or participation issues always raise issues of control. The conceptual separation of voice and control are artificial. The two are connected even though on the surface the connection appears concealed (Flynn, et al. 2004). Secondly union democracy as accountability or representation affects the model of unionism exercised and the nature of rights members can secure from their unions (Flynn, Brewster, Smith, \& Rigby, 2004; Hyman R. , 1978). When control of union leaders takes precedence over participation or voice, it tends to stifle consensus building which is crucial for maintaining union solidarity within a heterogeneous membership. Voting which serves as the main tool for securing membership control over their leadership suppresses consensus building (Flynn, et al. 2004). The prioritisation of one aspect of union democracy over the other also has implications for the determination of union membership priority, subsumes membership differences, and shifts the location of union decision-making. Union democracy that emphasises control over participation is likely to resort to centralised decision-making at the national level with a corresponding centralisation of union resources. In a reverse scenario, union resources will be decentralised and grassroots ideas in the determination of union agenda stressed on 
the assumption that all members have equal ability to contribute ideas for the development of union agenda (Flynn, et al. 2004). Whichever way unions conceptualise internal democracy, the main issues at play will be membership power to influence union direction for the pursuit of their interests.

Unions use power and influence for the pursuit of membership interests. Several factors underscore membership power, not least is internal democracy which strengthens internal coherence and membership solidarity. Unions are able to derive concessions from employers and the state when membership coherence around the point of union struggle is strong; and their subsequent actions have the potential to inflict severe economic and social damage for governments and employers. Union internal democracy is an important revival tool and it serves as a precondition for the success of union renewal strategies. The main challenge of globalisation to unions, as aptly summed up by Wood, is their ability to attract, retain and effectively represent members (Wood, 2004, p. 12). Effective representation is dependent on internal democracy which enhances membership cohesion and attracts nontraditional members to the union. Wood highlights this in the following terms:

Vibrant internal democracy makes unions more attractive to potential and present members, and enhances their capacity to engage in effective collective action. The latter gives unions more clout at both centralized and workplace levels, broadening the basis of participation in decision-making both over the day-to-day workplace governance, and in setting macro-economic policy (Wood, 2004, p. 398).

It is generally believed that union internal democracy reflects the positioning of union power within union structures (Hyman R. , 1978). The location of union activities have been shown as important for checking inherently oligarchic tendencies in union leadership (Harcourt 2004; Wood 2004b). Internal democracy is generally high where union power is located with its membership. The membership hold over their leaders remains strong when union activities are located at the local or shop floor level. Union leaders are more likely to yield to the corruptible influence of state or the ruling elite when union activity is driven from the leaders at the national level (Flynn, et al. 2004; Hyman 1978). Unions can exercise considerable power in the absence of internal democracy especially when accords with management or government offer concessions and give visibility to unions, especially their leaders. This power is however fragile because it is located within union leadership and can easily be undermined by more powerful social or political actors like governments or employers in the absence of the backing of union membership. Where union power is gained on condition of employer or state benevolence without membership support it is bound to be insecure. History has shown however that once unions are internally democratic, membership coherence and solidarity bolster unions' ability to survive the most serious attacks further enhancing union power and respectability (Andræ \& Beckman, 1998; Crisp, 1984; Jeffries, 1978). The power thus derived from membership is more reliable, and several situations serve to ensure its viability and survival. 
Union democracy, irrespective of how it is conceptualised, depends on membership power and union autonomy for the pursuit of members' rights. This point is highlighted by Kraus when he makes a direct connection between high level membership militancy and leadership accountability (Kraus 2007b). Crisp's historical account of the mine workers union in the Gold Coast colony and subsequently Ghana employs a framework of tools and agents of labour control and resistance to explain the connection between democracy and power within union struggles. Union struggles, he explains, have been directed by various agents of control whose weapon has been to undermine internal democracy (Crisp, 1984). In his hierarchy of power relations, he outlines four levels of power occupied by various groups within the production process. Workers, whom he calls order takers occupy the lowest position while at the apex of the hierarchy, he situates the order givers, metropolitan capital and core states, owners of the means of production. Their intermediaries, the subordinate order-givers, the colonial or post-colonial states, occupy the second position. Local mine management serves as local representative of capital to supervise and ensure workers' compliance with the unconditional expropriation of their surplus labour. Situated between the order givers and takers are the order brokers, the leadership of the GTUC and the national mine workers' union along with supervisors and traditional rulers who had been roped in to use their traditional ties to tone down workers' militancy. In this framework Crisp appears to support the position of radical theorists that trade union leaders serve more as tools for worker control and less as mechanisms for pursuing workers' interests (1984). He contends that the broker's role is the most ambiguous. Since they have responsibility for articulating the demands of workers to occupants at higher levels of the hierarchy, their credibility is sustained by the distance they are able to maintain with workers as order takers and management as subordinate givers or brokers (Crisp, 1984, p. 10). He differentiates varying forms of union resistance to capitalist control by their levels of visibility, inclusiveness and duration. Whether union resistance will be transformatory or reformist has implications for the development of working class consciousness. For Crisp, labour power assumes forms like resistance, assertion of autonomy and defiance (Crisp 1984). The outcome of resistance has also been of interest in terms of its potential to raise workers' consciousness to develop into a force that can undermine capital (Hyman, 1978). The implication of Crisp's framework for the examination of internal democracy lies in the tools it provides for locating the origins and targets of union resistance as well as delineating the role of all the players in the production system. It is unable however, to connect union resistance to other forms of struggle and identify the implications of such struggles for union internal democracy.

Andræ and Beckman make the connection between trade union power and internal democracy in their examination of labour regimes by noting that the bargaining power of trade unions determines the terms under which labour is ready to make itself available and willing to comply with capitalist demands (Andræ and Beckman, 1998). Labour regimes, the complex set of institutions encompassing rules and 
practices that regulate relations between labour and capital as manifest in the workplace, they explain, are part and parcel of the broader structures of social and economic power (Andræ and Beckman, 1998). Among the factors that strengthen labour's bargaining power are its organisational ability that enhances its potential to inflict costs on capital and management through non cooperation. Union role as an agent of social change is dependent on its power to force alterations in the capitalist productions system (Andræ and Beckman 1998; Hyman 1978; Jeffries 1978). Union actions can either be transformatory or reformist depending on where union action is being driven. Union actions driven from the grassroots or by the rank and file are more likely to lead to a fundamental questioning of the capitalist order than those originated for union leadership (Andræ \& Beckman, 1998; Hyman R. , 1978; Jeffries, 1978). When Hyman therefore insists that the possible impact of union action raises issues about the location of union activity he is pointing to issues of internal democracy (Hyman R. , 1978). It is for this reason that union internal democracy has remained a target for union control.

The constituents of union power therefore serve as determinants of union democracy calling for an examination of union power as the pivot of union democracy. Union power is determined by internal and external factors. External factors are the outcomes of union struggles, labour market conditions and the extent of capitalist accommodation of workers' demands (Kraus 2007b). Conditions within the larger economic and political environment, such as the central role of union in the determination of wage and labour market conditions, union permissive environment, level of economic development and labour force differentiation, inherited political norms and institutions - all serve to determine union power (Kraus 1988; Kraus 2007a). At union level, factors such as worker consciousness, members' solidarity, organisational capabilities and autonomy underscore union power (Kraus, 1988).

Crisp's framework helps to clarify the function and location of the various agents within the production system. The positioning of the state in relation to capital, for example, explains the peculiar role of the Ghanaian state in union history. Crisp's framework also assists in explaining how union leaders become possible targets of workers' struggles. It is not strong in offering an explanation of the conditions under which union leaders are able to identify with members and lead workers in a consistent struggle against capital. Neither can it offer useful leads for examining union internal dynamism as posed by membership heterogeneity. In their discussion on union power, Andræ and Beckman, used the concept of labour regimes to provide further understanding of determinants, sources and influencing factors of labour resistance (Andræ and Beckman, 1998). They also highlighted the interconnectedness of union power and other forms of social power relations. The labour regime framework also throws light on the role of the state within union actions. The state, especially the post colonial state in Africa, they explain, plays a mediating role that pits it against labour; first, its prominence on the labour market in terms of its large share of waged labour and, second, its responsibility for setting institutions 
and practices for the regulation of labour. Its mediating role between labour and capital has on several occasions set it in direct conflict with trade unions (Andræ and Beckman, 1998). The state in Ghana, since colonial rule, has featured prominently in the fortunes of organised labour, albeit the GTUC (Adu-Amankwah 1990; Britwum 2007; Crisp 1984; Gyimah-Boadi and Jeffries 2000; Jeffries 1978; Kester and Sidibe 1997; Kraus 2007b). Andræ and Beckman's labour regimes also help to situate union membership struggles directed against union leaders. By situating unions within the broader contest of social power relations it becomes possible to examine the operations of different forms of power relations within unions and how this is played out among the diverse forms of union members and their leaders in their encounters at the union level as unions set out to revitalise in the face of the challenge of globalisation.

\subsection{CONCLUSION}

Explaining globalisation as the prime mover of world economies is not without its problems. In terms of origins, outcomes, novelty and impact, agreement across theoretical traditions have been scarce. What is clear is the fact that globalisation has restructured development and production relations subjecting labour's status and function to fundamental changes. Labour is no longer the partner for national development and economic growth. In fact, its demands stand in the way of development and governments and employers are better off severing responsibility for maintaining high wages and social overheads. The nation state no longer serves to protect labour and promote its well-being. Rather it operates to mediate national spaces for the successful operations of FDI and TNCs. In the face of increasing social and environmental costs, even in places where the economic benefits of globalisation are celebrated, the role of this nation state becomes more crucial in ensuring that labour demands do not conflict with enterprise profitability.

Unions are not only important economic and political actors; they play significant democratic and industrial relations functions as well. Their operations are also important in protecting and promoting human rights of labour in a situation where the power of capital knows no bounds. As union relevance and effectiveness come under attack, its membership size dwindles and space for policy engagement gets eroded. Ultimately its existence is also threatened. Such globalisation challenges have promoted efforts on the part of unions to reverse their decline and build stronger structures to withstand the challenges of globalisation.

Labour renewal studies contend that strategies that have allowed a wider political orientation push unions to link workplace issues with broader issues of social justice (Turner, 2004). Limiting labour concerns to the workplace is likely to depoliticise unions and lend them to easy manipulation and domination by employers. Purely economic concerns are constraining and have a tendency to fixate unions on rules and regulations. Political concerns in contrast push unions to embrace wide- 
ranging social, political and economic issues thus broadening union concerns beyond the workplace and linking unions to societal struggles for change. The contours of labour concerns during union renewal or revitalisation are important in determining strategic partners and interests at which to direct actions. As they remain in several instances varying degrees of their original size and stature, unions continue to search for more effective strategies. However effective strategies are contingent on the ideological orientation, and have implications for the internal dynamism of trade unions.

Union form, that is, its size and density, relevance and effectiveness is dependent on its ideological orientation. It is its form that determines how unions measure up to the challenges of globalisation. Renewal, in terms of how unions recompose to reverse the impact of globalisation, alters unions form by reversing decline in size and density and improving relevance and effectiveness. For the outcome of union renewal to enhance union form within globalised economies, union repertoire must allow the identification of strategies that enlarge union perspectives, improve internal democracy and reverse decline. Renewal studies therefore, should be able to address how the internal structures of trade unions are being impacted, the forms of power tools made available to union members and how union renewal mediate members' access to such tools. But how have unions fared in their efforts at renewal, and what factors have guided and shaped their repertoires? The later chapters will examine some union renewal efforts and their implications for internal democracy. Before that however, the study methods are discussed and background information on the GTUC is also provided. 
Chapter 3

METHODOLOGY 


\title{
3 METHODOLOGY
}

\begin{abstract}
Unravelling the pressures renewal strategies impose on union internal democracy demands a research approach that will advance the understanding of how such strategies can alter internal relations and processes to delineate membership space in union structures, processes and activities. Case studies provide the approach that lends itself to the use of research methods and analytical techniques most suited to capturing events and processes still in form. Its inherent ability to compromise the validity and reliability of research quality were countered through the use of multiple methods and respondent checking. Three levels of coding were used to interpret the data gathered. The fieldwork involved interviews and document review as well as observation of union events in six regions of Ghana. The GTUC and six of its national affiliates formed the cases that were covered.
\end{abstract}

\subsection{INTRODUCTION}

Union revitalisation strategies are crucial because of the import of their outcome for reversing membership decline and their tendency to modify internal relations and membership space within unions. As unions embark on strategies to combat the impact of economic reform and workplace restructuring, some levels of internal displacement of membership is bound to emerge. The usual concerns of union renewal studies have been the contribution of strategies for renewal especially in reversing decline in union size. Factors that impact union strategic choices are known, so are the determinants of strategic outcomes. Focus on strategies and how they impact internal dynamism of unions are only beginning to attract attention. At the centre of this study were issues of internal democracy that come to the fore as union set out to revitalise. The subject and focus of the study therefore demanded an approach that would provide the occasion to examine peculiar cases as well dominant trends especially since union experience of globalisation has varied for economic and industrial sectors even in the same national environment. While some sectors have been more exposed to direct contact with globalised capital, in the form of FDIs, variations in the specificities of union challenges have produced different levels of informalisation or formalisation. The study was interested in similarities as it was in 'deviant' cases for their known potential to enrich discussion on how union strategy outcomes might impact internal democracy. 
Studying union situation is dictated by the research subject and spatial location either at the plant, national or confederation level. The case study has largely proven the most appropriate research approach (Hyman R. , 2001). Defined by George and Bennett, as 'a class of events that an investigator chooses to study with the aim of developing theory...regarding causes of similarities among instance...of that event' (George \& Bennett, 2005, pp. 17-18), the case study has served to provide the necessary mix of methods for studying union events and processes at the various levels of union organisation. Methodologically the case study is presented more as a research approach utilising a range of methods like interviews, observations and document reviews. The final mix of methods chosen is dictated by the nature of the class of events being studied (Haynes, 2005). The attraction to case study in union research is its ability to allow the research focus to determine how it is studied (Haynes, 2005).

The case study presented itself as an appropriate approach to interrogate union strategies since they constituted unfolding events that could not be controlled in the research setting (George \& Bennett, 2005). As George and Bennett explain, the case study makes possible the investigation of contemporary phenomenon within its real life context, when boundaries between phenomenon and context are not evident and do not allow for manipulation (George \& Bennett, 2005). This point is corroborated in the observation that the case study is best suited for capturing high variability in situations where direct manipulation of variables is impossible (Yin, 2008; Haynes, 2005). This study aimed to capture trends of union challenges and the emerging strategies and the resulting dynamics of internal democracy that shape union structure and identity. The implementation of union strategies is an on-going process in a context of continuous challenge of globalised production norms at the workplace.

Case study also enables a focus on the 'what and how' of the events being studied and not the 'why' (George \& Bennett, 2005; Haynes, 2005; Grix, 2004; Yin, 2008). The research content, context and outcome therefore provide direction to the approach for its study. The significance of the case that is being studied and its relationship to the class of events chosen for study determines how rounded and comprehensive the outcome of findings can be extended into other realms (Haynes, 2005). The choice of the case study as a research approach therefore is influenced either by its representativeness or its uniqueness. This flexibility in choice of cases in the case study approach allows similarities and differences or deviant or outlier cases to be exposed (George \& Bennett, 2005). But perhaps more significantly is the occasion it provides for detailed study of individual cases (George \& Bennett, 2005). Other strengths of the case study approach are the ability of the research process to conserve the unitary character of the social object being studied (Haynes, 2005; Grix, 2004). Multiple methods of data gathering or methodological triangulation that the case study embodies help to reduce possible investigator deficiencies that can compromise research validity and reliability (George \& Bennett, 2005; Gibbs, 2007). One 
other issue that informed the choice of case study as a methodological approach is that it allows the investigation of contemporary events in their real-life contexts from several sources of evidence (Yin, 2008).

The appropriateness of the case study for trade union research is however not without challenges. Its limitations as a research approach include the element of selective bias, how to delineate case units, and compare multiple cases. In determining the unit case the usual challenge that has emerged has been whether to focus on local, industrial, national unions or confederations. The decision whether to study trade unions as institutions or delineate union processes as the centre of attention have also not presented an easy option for trade union researchers (Hyman, 2001). Other limitations of the case study are ensuring validity and reliability of findings and the extent to which such findings can be generalised. By stressing the uniqueness of the events selected, the case study approach falls prey to the 'selection bias', a limitation which weakens the estimation of 'causal effect or causal weight of variables across a range of cases' (George \& Bennett, 2005).

Another area of contestation is the comparative inter-union or cross national trade union research (Hyman R. , 2001, p. 206). The feasibility of true comparative trade union research, according to Hyman, is contested on the grounds that unions are diverse entities circumscribed by their peculiar situations, be it the workplace or the industrial union (Hyman R. , 2001, p. 206). Hyman cautions such a position, wary of the suggestion that cross comparative study of unions at every level is impossible. Unions as distinct entities are shaped by various historical and spatial contexts. Trade unions therefore are a collection of several local situations that shape their form, structure and identity (Hyman, 2001). Union diversity is real. However, this diversity does not exclude unique similarities by which unions can be distinguished from other groups. Unions serve as representative organs for workers as they engage in offering their labour power for survival. The fact that unions embody, in the same space and time, dominant traits of homogeneity and heterogeneity raises challenges about the levels cases can be delineated for comparative study. This does not however make comparison in research impossible. The strength of the case study in determining whether and how specific issues matter to the outcome of events and processes, in fact, highlights its suitability for trade union research that focuses on understanding how specific processes and events shape relations among members once issues of validity and reliability can be brought under control.

\subsection{DelineATing THE STUDy CASE}

Haynes explains that the point of examining a case in research is its significance as an example of the broader phenomenon under study (Haynes, 2005). The GTUC stands as a unique case because it is the oldest labour centre in Ghana spanning 60 years of existence though its antecedents date much earlier (Adu-Amankwah, 1990; Cowan, 1960). The most viable alternative labour centre, the Ghana Federation of 
Labour (GFL), founded in 1999, has, at its core, a breakaway faction from the ICU: the Textile, Garment and Leather Employees' Union (TGLEU). Other workers' groups, like the Ghana National Association of Teachers, Civil Servants Associations and Ghana Registered Nurses Association are, as their names suggest, associations, and do trace their origins to the GTUC. An attempt to form an alternative Labour Centre under the GFL by these labour groups has not been too successful. The prominent status of the GTUC therefore made it a worthwhile choice for the study on the implications of trade union renewal strategies for union internal democracy in Ghana.

Having selected the GTUC as the focus of study, the next question was the choice of a unit of analysis. The research was directed at seeking holistic understanding of the context of trade union strategies while searching for what Hyman cites as contextually unique cases (2001). It was necessary to settle on a research unit that would allow the examination of variations within the union setting which had been modified by sector specific policy initiatives and responses to globalised economic terrain. The enormous variations within the affiliated national unions that make up the GTUC rendered the confederation level, as the unit of analysis, unwieldy. Preliminary interviews with the General-Secretaries of the national unions confirmed MacDuffie's assertion as quoted by Hyman that globalisation has undermined the distinctiveness of national employment regimes to the extent that it becomes difficult to speak of standardised national labour markets and work practices (2001). Increasing economic sectors have been differentiation as a result of variations in the speed and levels of transformations imposed by difference in deregulation and flexibility. Using this perspective, Hyman (2001) asserts that one might find similar levels of variations between industrial sectors in a country as exist between nations. National unions by virtue of the fact that they organise in disparate economic sectors face dissimilar forms of challenges and as such were engaged in varied combinations of strategies for renewal.

The 17 national unions of the GTUC and the breakaway ICU, fall into four broad categories, depending on which sector of the national economy the majority of their members are located in (Table 3.1). Apart from the fact that all but one national union, the GPRTU, draw the majority of their members from the formal economy, seven $(41 \%)$ organise predominantly in public enterprises (Table 3.1). Four (24\%) had their membership base mainly in private sector and the remaining (29\%) had a mix of members drawn from both private and public sector enterprises (Table 3.1). 
Table 3.1

Predominant Membership Base of National Unions of the GTUC

\begin{tabular}{|c|c|c|c|}
\hline Membership source & National Union & No & $\%$ \\
\hline \multirow[t]{8}{*}{ Public } & Health Services Workers Union (HSWU) & \multirow{8}{*}{7} & \multirow{8}{*}{41.2} \\
\hline & Local Government Workers' Union (LGWU) & & \\
\hline & Public Service Workers' Union (PSWU) & & \\
\hline & Public Utilities Workers' Union (PUWU) & & \\
\hline & Railway Enginemen's Union (REU) & & \\
\hline & Railway Workers' Union (RWU) & & \\
\hline & Teachers' and Educational Workers' Union (TEWU) & & \\
\hline & $\begin{array}{l}\text { General Transport, Petroleum and Chemical Workers' } \\
\text { Union (GTPCWU) }\end{array}$ & & \\
\hline \multirow[t]{4}{*}{ Private } & Construction and Building Workers' Union (CBMWU) & \multirow[t]{4}{*}{4} & \multirow[t]{4}{*}{23.5} \\
\hline & Communication Workers Union (CWU) & & \\
\hline & Ghana Mineworkers' Union (GMWU) & & \\
\hline & National Union Of Seamen (NUS) & & \\
\hline \multirow[t]{5}{*}{ Public/Private } & General Agricultural Workers' Union (GAWU) & \multirow[t]{5}{*}{5} & \multirow[t]{5}{*}{29.4} \\
\hline & Maritime and Dockworkers' Union (MDU) & & \\
\hline & Timber and Wood Workers' Union (TWU) & & \\
\hline & $\begin{array}{l}\text { Union of Industry, Commerce and Finance Workers } \\
\text { (UNICOF) }\end{array}$ & & \\
\hline & Industrial and Commercial Workers' Union (ICU) & & \\
\hline Informal Economy & Ghana Private Road Transport Union (GPRTU) & 1 & 5.9 \\
\hline \multicolumn{2}{|l|}{ Total } & 17 & 100 \\
\hline
\end{tabular}

Source: Field Data; 2008

Though public sector enterprises have not been spared restructuring, massive retrenchment has dropped considerably and the public sector still leads, in terms of the protection of workers' rights (African Labour Research Network, 2004). It is in the private sector that unions face the most acute forms of challenges because privately owned industries tend to operate more in line with globalised norms of efficiency-induced cost-cutting measures and worker individualisation.

The national unions served as the unit of analysis for sector variations in union experiences while the union confederation provided the overarching union situation. The choice of several unions was not to undertake a comparative study described by Hyman as 'the systematic cross-analysis of phenomena displaying both similarities and differences' (Hyman R. , 2001, p. 205). The purposive selection of six 
national unions for study made the research a multiple case approach. Multiple case studies have been acknowledged as means for controlling variables in the field to allow researchers to get round the difficult problem of manipulation in social science research (Gibbs, 2007; Grix, 2004; Hyman R. , 2001). The choice of multiple cases was therefore to provide a better understanding of variations in union responses and internal dynamics and to strengthen the internal and external validity of the research.

The choice of national unions as case units was influenced by the national sectors in which unions draw their members, especially those sectors that were in direct contact with globalised capital and where there were high levels of investments from private both local and foreign sources. The study deliberately cut out public sector based national unions on the assumption that their levels of challenges were tempered by the predominantly public framework in which they operated. National unions based in the private sector were therefore the preferred choice. However in order not to lose the public dimension to trade union challenges, unions with a balance of membership drawn from both the public and private sectors were also chosen. Factors that guided the final choice of national unions were their levels of challenges and the nature of informalisation that the sectors in which they were based were experiencing. The GPTRU was added because of its predominant informal economy base and the ICU for the controversy that had characterised its leadership since 1992 and its final disaffiliation from the GTUC in 2004.

Six national unions were chosen based on the industrial sectors where they organised and the intensity of globalisation challenges to their effectiveness and relevance. Each of the 17 National Unions of the GTUC had a unique experience of globalisation and their responses differed in terms of intensity and range of strategies. In addition, the enthusiasm and dedication of union leaders to union strategies varied. National Unions' challenges have differed because of the economic sectors in which they organise. Neo-liberal policies of government take different forms across the various economic sectors and impact work and work relations differently. It has been the workplace changes and altered work relations that have modified the contours of trade unionism forcing unions to respond in diverse ways. The sections that follow outline the background and context of the GTUC and the six national unions selected for study.

\subsection{GTUC AND THE CASE NATIONAL UNIONS}

The GTUC, a confederation of 17 national unions, was formed under Ordinance in 1946 as a response of the British colonial government to persistent labour unrests. Prior to 1946, trade unions, with the exception of the Railway Workers' Union and Mineworkers' Union, were short-lived house unions, organized to lead demands for improved and fair working conditions (Britwum, 2007; Panford, 1996; Arthiabah \& Mbiah, 1995; Kraus, 1988; Crisp, 1984; Cowan, 1960). Factors militating against the 
growth and effective operation of unions during colonial rule were the hostility of the private expatriate employers and the colonial government. The colonial labour market was predominantly agrarian with agricultural production undertaken on a subsistence level. The waged workforce was in the minority. The colonial administration provided employment for a large proportion of the waged workforce. Other forms of waged employment were located in construction, mining, plantation agriculture and rail transport (Britwum, 2007b; Panford, 1994; Kraus, 1988; Cowan, 1960). It was within this small waged section of workers that the main GTUC and its affiliates developed.

The predominant base of the GTUC in the formal economy has lent its form and structure to the dictates of state political and economic policy orientation. Kraus explains that government attitude to the GTUC has had a two-fold objective to either capture its support through cooption or, failing that, dampen trade union opposition through coercion (Kraus, 2007). Under colonial rule, trade unions were engaged more at the enterprise level, fighting for improved working conditions. The active involvement of the GTUC in the struggle for independence from British colonial rule gave it some measure of credibility within the political arena of independent Ghana. Since independence, trade union/state relations have vacillated from friendliness to hostility thereby impacting unions in various ways. Trade union cooperation with labour responsive governments like the Convention People's Party (CPP) in the late 1950s as well as the National Redemption Council (NRC) governments in the 1970s produced labour friendly legislation that facilitated the positioning of the GTUC as the dominant labour centre in Ghana (Britwum, 2007b). Close collaboration with cooperative governments have their tradeoffs like distancing union members from their leaders and producing a trade union agenda that sidelined the direct concerns of union members (Crisp, 1984; Jeffries, 1978). Conversely, hostile governments have promoted trade union militancy calling for membership mobilisation which sometimes unites members behind their leaders for political agitation (Britwum, 2007; Crisp, 1984; Jeffries, 1978).

The characteristic tremulous union state relations have been dictated by economic policy choices of governments, the personal interests of the ruling political class and the resulting economic fortunes of the country. In the absence of an indigenous capitalist class, the Ghanaian state assumes the role of facilitating capital accumulation in the interest of foreign capital (Adu-Amankwah, 1990; Ninsin, 1989; Kraus, 1988). Various governments have tried to deal with the accumulation crises that have typified Ghana's development through various alliances with foreign capital. Trade union/state relations have vacillated in response to the nature of such alliances since they have dictated the extent to which the interests of the working people of Ghana have interfered with the process of capital accumulation (Ninsin, 1989). The Ghanaian state has acted mainly in the interest of foreign capital and the personal interests of members of the ruling class (Crisp, 1984). These interests have 
in most instances clashed with those of workers since they have undermined working conditions (Britwum, 2007; Kraus, 2007; Nugent, 1995; Ninsin, 1989; Jeffries, 1978).

In the immediate period after independence, the GTUC enjoyed good relations with the state under CPP rule. Several actions were undertaken to secure workers' interests and also enhance trade union power and influence (Britwum, 2007; Jeffries, 1978). These included the recognition of the GTUC as the workers' wing of the ruling CPP, space in economic decision-making, and gifts of economic ventures to supply workers with consumables at reduced rates and offer unions occasion to earn extra income. Union headquarters, the Hall of Trade Unions, was a gift from the CPP government. The Industrial Relations Act, 56 of 1958 which replaced the Trade Union Ordinance CAP 91 and later amended by the Industrial Relations Act, of 1960, Act 299 obliged employers to bargain with unions, introduced the check-off for the collection of union dues and gave the GTUC a sole representative status of organised labour in Ghana (Britwum, 2007). As the economic fortunes of Ghana waned, worker discontent was countered by restrictions on the right to strike, and cooption of union leaders through ministerial and diplomatic appointments $(\mathrm{Nu}-$ gent, 1995; Crisp, 1984; Cowan, 1960).

The GTUC's open support for the CPP regime took a heavy toll on union internal cohesion and membership solidarity and allegiance to their union (Britwum, 2007; Kraus, 1988; Jeffries, 1978; Arthiabah P. , 1974; Cowan, 1960). The military junta named the National Liberation Council (NLC) and its immediate successor the Busia led Progress Party (PP) set out to liberalise the economy through foreign participation, halted investments in developmental projects, devalued the national currency and introduced cuts in social wages. In a period of one year 60,000 public sector workers were laid off (Britwum, 2007b). When worker militancy grew the PP government resorted to legislation to curb union strength. Under a certificate of urgency parliament sat over night to enact the Industrial Relations Amendment Act 383 of September 13, 1971 to dissolve the GTUC granting autonomy to the national unions, abolishing the check-off system, and curtailing the right of unions to collectively bargain and strike. The sector minister gained absolute power to determine union eligibility to bargaining certificate and to settle disputes (Britwum, 2007b). In short, worker militancy was curbed. The national leadership of affiliated unions acted promptly to acquiesce to the dictates of Act 383. Union assets were sold and national union constitution brought in line with the demands of the law. It took a military takeover in January 1972 to restore the GTUC (Britwum, 2007; Arthiabah \& Mbiah, 1995; Cowan, 1960).

The National Redemption Council (NRC), under the leadership of Colonel I.K. Acheampong, passed the Industrial Relations Amendment Decree 1972 (NRCD.22) to nullify Act 383. The NRC and its later variants Supreme Military Councils I and II (SMC I \& II), gave a boost to union existence through economic policies and legislation. There was a surge in union membership and financial growth, the direct result 
of investments in construction and expansion in economic activity (Konings, 2003). Cooption of union leadership into government however produced the characteristic gap between leadership and membership shifting the site of worker protests outside the national unions into the workplace. Union leaders failed to provide the necessary fulcrum for mobilising against corruption and economic mismanagement by NRC/SMC regime. Whatever gains in legislation the GTUC obtained from the NRC/SMC were undermined by the corruption and economic mismanagement by these regimes that collapsed the Ghanaian economy in the 1970s. Succeeding governments, the Armed Forces' Revolutionary Council (AFRC) and the Peoples' National Party (PNP) are noted perhaps for their lack of clear economic policies. The former because of its limited political agenda of clearing the economic muddle created by previous military regimes and the latter for its unprecedented lack of economic vision and political will. Failure to provide a clear cut direction to deliver Ghana out of its economic woes however brought workers and the PNP government into conflict (Britwum, 2007; Nugent, 1995). Economic deterioration produced several incidents of workers' agitations against government's inability to pay workers on time, unilateral rescheduling of effective dates for collective bargaining. A total of 2,000 workers were dismissed in 1981 when they stormed parliament to demand payment of salary arrears. Such actions left no doubt about the PNP government's attitude towards workers' welfare. The policy inertia deepened Ghana's economic problems further and set the stage for the economic reforms that the Provisional National Defence Council (PNDC), the military regime that toppled the PNP government, embarked on (Britwum A. O., 2007; Nugent, 1995; Shillington, 1992).

Under the PNDC workers found the Workers' Defence Council (WDC) a useful vehicle for expressing their discontent with management ineptitude and union leadership insensitivity to their concerns (Britwum, 2007; Graham, 1989; AduAmankwah, 1990). Workers used their solidarity demonstration for military takeover in 1982 to heckle national trade union leaders and to demand the resignation of the Secretary-General. At the workplace, the WDC's either replaced the locals or became their supervisors, shifting worker militancy outside the GTUC. Things boiled to a head when in April 1982 the Association of Local Unions (ALU), led by workers from Accra and Tema, besieged the GTUC headquarters, the Hall of Trade Unions, announcing the dissolution of the executive board of the GTUC and the National Executive Committees (NEC) of the National Unions. They had the complicity of the PNDC in the form of police deployment at the Hall, the arrest and detention of the ousted union leaders as well as violent repression of protesting workers from Sekondi-Takoradi by the army (Britwum, 2007; Nugent, 1995). ALU set to reform union leadership/membership power relations in the national unions and the GTUC. Emergency conferences of National Unions and Congress of the GTUC were called to effect the required constitutional backing (ibid). Workers' expectation that the populist pronouncements of the PNDC would lead to improved industrial relations environment was soon dashed when the government resorted to 
support from the IMF and World Bank to solve the nation's economic problems (Konings, 2003). The WDCs and their community based counterpart, the Peoples' Defence Committees (PDCs), were the first organs of the revolution sacrificed in the efforts of the military regime to gain credibility for doing business with the IMF and the World Bank. They were replaced by the faceless Committee for the Defence of the Revolution (CDRs) (Britwum A. O., 2007; Shillington, 1992; Adu-Amankwah K. , 1990; Graham, 1989).

Economic reforms dictated by the IMF and World Bank required the curbing of workers' rights, producing what has been describe as the longest period of rancorous relations between organised labour and the state in Ghana (Boafo-Arthur, 1999; Adu-Amankwah, 1990). Economic reforms or SAP consist of a standard set of prescriptions by the IMF and World Bank that seek to make economies more liberal, reduce state involvement in production, curb social expenditure, ostensibly to make governments more prudent in spending and make national enterprises competitive. In reality however such policies have facilitated the transfer of state-owned properties to foreign private interests and eroded workers' ability to defend their right to decent work and living conditions. Privatisation of state-owned enterprises and the rationalisation of public institutions led to massive retrenchment of workers and union membership losses were monumental (Fine \& Boateng, 2000). The violence required to implement SAP policies in Ghana took the form of arbitrary dismissals of unionised workers, restrictions on the use of collective bargaining to defend workers' interests, legal facilities to freeze wages and deny retrenched workers due compensation and by-passing established industrial relations channels (Britwum, 2007b, pp. 47-53). Whatever worker militancy was left was subjected to divisive tactics to break workers' front and media lynching to malign workers and their leaders in the minds of the Ghanaians (Konings, 2003). By the end of the PNDC rule, most unions were just a fraction of their pre-SAP sizes, membership demoralised and dwindling union finances constricted union support to its members (Britwum, 2007). Constitutional rule under the National Democratic Congress (NDC) brought little respite to unions since the interests of capital had to be served. Wary of keeping its expenditure in check, the Government of Ghana (GOG) froze public sector wages in 1994 and continued to refuse retrenchment payments. This time about 10,400 retrenched COCOBOD workers had their severance award withheld (ibid).

The New Patriotic Party (NPP) that replaced the NDC in 2001 offered little in terms of policy change to lighten the industrial relations environment and bring about a relief to workers. NPP is the present day version of the PP government of the late 1960s and early 1970s that had subscribed to neo-liberal policies even at a time when social welfare capitalism was the norm. Taking over the reins of power in the 2001 during the height of globalisation it was emboldened to entrench the interest of foreign capital and it made no secret of this during its campaign for power when it promised Ghanaians a 'property owning democracy and a golden age for businesses'. The recourse to Highly Indebted Poor Country Initiative (HIPC) introduced 
more neo-liberal policies like the deregulation of fuel and energy and the privatisation of water. Highly priced public enterprises were privatised, notable among them were the Obuasi Goldfields, and later the Ghana Telecom in 2008, amid much political controversy and public outrage.

In terms of labour legislation, the enactment of the Labour Act, Act 651 of 2003 ostensibly to bring together the numerous legal instruments governing labour, in reality promoted the interests of foreign investors, who for the unabashedly rightleaning NPP government, constituted the panacea for national development. The NPP ruling cohort was in no doubt about whose interests the Labour Act should serve. ${ }^{2}$ Perhaps Act 651 is the most significant event to impact union survival and effectiveness under NPP rule. It abolished closed shop unionism and reduced the number of persons required to form a union to two, much to the consternation of trade union leaders. Union leaders interviewed find this provision ludicrous questioning its practicality. They asked 'so who will constitute the executive and who will be the membership in a two-person union?' and lament that even the colonial government gave trade unions better protection by pitching the minimum number of members at five. ${ }^{3}$ Other challenges introduced by Act 651 are the position of nonpermanent workers and the inability of unions to utilise the Labour Act to promote their interests.

Other pro-capitalist legislations that have undermined working conditions in Ghana include the Procurement Act and repeal of the Act that imposed high tariffs on importation of rice and poultry. Here again the economic policy of the ruling government subordinated workers' interests to those of private capital. The excuse has been to attract investments to generate jobs. Foreign direct investments have hardly expanded job creation. On the contrary the net effect of such legislations has been a reduction in employment conditions as market share of the products of local companies shrink and workers are laid off after privatisation. The poultry and rice industry have been the worst hit. The Ghanaian textile industry unable to cope with dumping facilitated by trade liberalisation has virtually collapsed (Public Agenda, 2008).

To secure its hold on political power the NPP government sought to court the favour of Ghanaians through the setting up of a National Health Insurance Scheme (NHIS) to replace the cash and carry system. This meant the illegal, unilateral appropriation of $2.5 \%$ of workers' $17.5 \%$ social security contribution. The NPP government utilised its control over the media to malign the trade union leadership and sway public opinion in its favour and by that diffused workers' opposition to the

\footnotetext{
${ }^{2}$ The sector minister's memorandum to the passing of Act 651 mentioned the need for the revision of existing labour law to provide an enabling environment for private investment; (Britwum, Enu-Kwesi, \& Arkosu, 2006).

${ }^{3}$ Interview with union leaders, 2008
} 
illegal appropriation of their pension (Britwum, 2007b). Union/state relations have been less hostile under the NPP even though liberalisation has led to the collapse of industry and loss of jobs, and union effectiveness waned, the GTUC has resorted to issuing memorandum on government policy as a tool for engaging state policy. One notable feature is the yearly comment of the GTUC on government's annual budget (Britwum, 2007b).

Table 3.2 Trade Union/State Relations Historical Trends

\begin{tabular}{|c|c|c|c|}
\hline Regime & Date & Regime Type and Head & Union State Relations \\
\hline $\begin{array}{l}\text { Convention } \\
\text { Peoples' Party } \\
(\mathrm{CPP})\end{array}$ & $1957-1966$ & $\begin{array}{l}\text { Civilian: } \\
\text { Dr. Kwame Nkrumah }\end{array}$ & $\begin{array}{l}\text { Pro-worker/Union legislation } \\
\text { Conferring favours: resource acquisi- } \\
\text { tion } \\
\text { Leadership Cooptation } \\
\text { Curbing workplace influence } \\
\end{array}$ \\
\hline $\begin{array}{l}\text { National Libera- } \\
\text { tion Council } \\
(\mathrm{NLC}) \\
\end{array}$ & 1966- 969 & $\begin{array}{l}\text { Military: } \\
\text { Gen J A Ankrah }\end{array}$ & $\begin{array}{l}\text { Restrictive legislations } \\
\text { Violent repression } \\
\text { Media verbal lynching }\end{array}$ \\
\hline $\begin{array}{l}\text { Progress Party } \\
(\mathrm{PP})\end{array}$ & $1969-1972$ & $\begin{array}{l}\text { Civilian: } \\
\text { Dr Kofi A Busia }\end{array}$ & $\begin{array}{l}\text { Restrictive legislations } \\
\text { Media verbal lynching }\end{array}$ \\
\hline $\begin{array}{l}\text { National Re- } \\
\text { demption Coun- } \\
\text { cil (NRC) }\end{array}$ & $1972-1975$ & $\begin{array}{l}\text { Military: } \\
\text { Colonel I K Acheampong }\end{array}$ & $\begin{array}{l}\text { Conferring favours: resource acquisi- } \\
\text { tion leadership Cooptation } \\
\text { Curbing workplace influence }\end{array}$ \\
\hline $\begin{array}{l}\text { Supreme Mili- } \\
\text { tary Council } \\
\text { (SMC I) }\end{array}$ & $1975-1978$ & $\begin{array}{l}\text { Military: } \\
\text { General I K Acheampong }\end{array}$ & $\begin{array}{l}\text { Restrictive legislations } \\
\text { Leadership Cooptation } \\
\text { Curbing workplace influence }\end{array}$ \\
\hline $\begin{array}{l}\text { Supreme Mili- } \\
\text { tary Council } \\
(\mathrm{SMC} \mathrm{II)}\end{array}$ & 1978-1979 & $\begin{array}{l}\text { Military: } \\
\text { Gen. Fred Akuffo }\end{array}$ & $\begin{array}{l}\text { Cooptation } \\
\text { Restrictive legislations } \\
\text { Restrictive legislations } \\
\end{array}$ \\
\hline $\begin{array}{l}\text { Armed Forces } \\
\text { Revolutionary } \\
\text { Council (AFRC) } \\
\end{array}$ & $\begin{array}{l}\text { June-Sept } \\
1979\end{array}$ & $\begin{array}{l}\text { Military: } \\
\text { Flt Lt Jerry J Rawlings }\end{array}$ & $\begin{array}{l}\text { No Clear cut relationship } \\
\text { No clear cut impact }\end{array}$ \\
\hline $\begin{array}{l}\text { People's Na- } \\
\text { tional Party } \\
(\mathrm{PNP})\end{array}$ & $\begin{array}{l}\text { Sept } \\
1979- \\
\text { Dec1981 } \\
\end{array}$ & $\begin{array}{l}\text { Civilian: } \\
\text { Dr Hilla Liman }\end{array}$ & $\begin{array}{l}\text { No Clear cut relationship } \\
\text { No clear cut impact }\end{array}$ \\
\hline $\begin{array}{l}\text { Provisional } \\
\text { National De- } \\
\text { fence Council } \\
\text { (PNDC) }\end{array}$ & 1981-1992 & $\begin{array}{l}\text { Military: } \\
\text { Flt Lt Jerry J Rawlings }\end{array}$ & $\begin{array}{l}\text { Media verbal lynching } \\
\text { Direct control } \\
\text { Restrictive legislations } \\
\text { Curbing workplace influence } \\
\text { Violent repression }\end{array}$ \\
\hline $\begin{array}{l}\text { National Democ- } \\
\text { ratic Congress } \\
(\mathrm{NDC})\end{array}$ & $1993-2000$ & $\begin{array}{l}\text { Civilian: } \\
\text { Flt Lt Jerry J Rawlings }\end{array}$ & $\begin{array}{l}\text { Restrictive legislations } \\
\text { Curbing workplace influence } \\
\text { Media verbal lynching }\end{array}$ \\
\hline $\begin{array}{l}\text { New Patriotic } \\
\text { Party (NPP) }\end{array}$ & $2001-2008$ & $\begin{array}{l}\text { Civilian: } \\
\text { John A Kuffuor }\end{array}$ & $\begin{array}{l}\text { Manipulation } \\
\text { Restrictive legislations } \\
\text { Media verbal lynching } \\
\end{array}$ \\
\hline
\end{tabular}

Source: Developed from Britwum, 2007b: Chapter 2, pp17-67

Table 3.2 summarises the devices utilised by various ruling governments to extract support from the GTUC for their policy direction or prevent organised labour from opposing their economic policies and thereby undermining their hold on power. 
The devices have included efforts to co-opt union leadership or court membership compliance by conferring favours in the form of physical and financial resources as well as pro-worker or union friendly legislation (3.2). The main ploy however, has been outright hostility in the form of leadership cooption, manipulation of public opinion against workers and their leaders through media lynching, restrictive legislations, violent repression and direct interference.

The structure and form of the GTUC and its national unions have been shaped by national economic policy orientation that has produced varying forms of interests in union governance for members, union leaders and groups opposed to the ruling government. Thus the GTUC in its current form is the result of historical economic and political events in Ghana. This makes the GTUC an interesting case for investigating the impact of economic policies derived from globalisation on union form and structure as it struggles to implement strategies to counter the impact of globalisation challenges. The national unions provide more vivid forms of specificities of union experiences and the nature of challenges globalisation has imposed on the Ghanaian workforce.

As indicated earlier, the six national unions selected were located in distinct economic sectors where the impact of globalisation had been most severe, each contending with different packages of enterprise and workplace reforms. Their responses have differed in overall strategies or sometimes in terms of detail and so have the levels of commitment and degree of seriousness with which strategies were being implemented. Below is a profile of the national unions covered in the study.

1. Construction and Building Materials Workers' Union (CBMWU), formed in 1954, organises workers in the construction and allied industry in Ghana. Initially construction was public-dominated, with several state owned enterprises, like the State Construction Company (SCC) and the Public Works Department (PWD), Ghana Highways Authority, Architectural and Engineering Services Corporation. The SCC was divested and its entire workforce retrenched during economic reforms. The Ghana Highways Authority has since 1978 had its core operations gradually outsourced to private companies and its main functions downgraded to supervision and occasional maintenance of roads (Britwum, 2007b). In the same manner, the PWD has had most of its functions ceded to the private sector. By the early 1990s, the CBMWU had been reduced to $30 \%$ of its 1980 membership of 40,000 (Fine \& Boateng, 2000).

The Ghanaian construction industry is currently dominated by foreign companies, especially of Chinese origin, who, the national leadership of CBMWU insist, have no respect for national labour laws. Foreign domination has been facilitated by the Procurement Act introduced ostensibly to make Ghanaian enterprises efficient and stifle corruption by opening the bidding for local con- 
tracts to international competition. There is palpable scepticism about the extent to which the Procurement Act has promoted efficiency and transparency and curtailed corruption. However construction companies have resorted to insecure employment forms in order to remain competitive. The construction industry, as a result, is highly informalised. The main avenues for meeting the supply of workforce are sub-contracting, indirect recruitment and employment of nonpermanent workforce. Thus, while the nation has seen a boom in construction since economic downturn in the 1970s, this has not reflected in the working conditions of the construction workforce. The CBMWU within two decades moved from a stable membership of public sector based permanent workers to private sector based casual and temporal highly mobile employees. One feature of the CBMWU has been internal instability and union fragmentation, with the formation of a rival union, the Construction and Allied Workers' Union which is poaching the remaining membership. Again, organising in the construction industry makes the union male dominated. There have been measures instituted to expand union membership and improve union relevance to members. The CBMWU therefore provides an interesting case for this study that is seeking to explore and explain the impact of union renewal strategies on union internal democracy.

2. General Agricultural Workers' Union (GAWU) organises workers in the formal and informal agricultural sectors in public and private employment. Like the CBMWU, it was, on formation in 1959, a wholly formal economy based union with the majority of its members employed on state owned plantations and agricultural servicing enterprises like the Cocoa Services Sector, Council for Scientific and Industrial Research, Ministry of Agriculture, Forestry Division, Game and Wild Life, as well as the Parks and Gardens (Britwum, 2007b). These enterprises have either been restructured and workers retrenched, or, as in the case of the state owned plantations, privatised or closed down. The result was that by 2005 GAWU membership had reduced to 21\% of its 130,000 in 1982 (Britwum A. O., 2007). Union challenges from globalisation include enterprise and workplace restructuring like outsourcing, subcontracting, casualisation and enterprise fragmentation. GAWU was the first national union to set up a women's wing and restructure its internal structures to give space to women's workers and the rural self-employed. At present, the rural self-employed members constitute over $53 \%$ of its membership. Its choice for this study was also influenced by its early focus on women trade union members and the incorporation of rural self-employed agricultural workers into union structures.

3. Ghana Mine Workers' Union (GMWU) was formed in 1944 to organise workers in the mining industry. The public dominated mining sector was largely run-down in the late 1970s and the solution to its revival was sought in the form of massive foreign direct investments. The attendant privatisation that ensued led to the shedding of large numbers of mine workers (Fine \& Boateng, 2000). 
By 2006, labour retrenchment had reduced the size of the GMWU from 22,000 in 1987 to $10,000^{4}$. The fortunes of the mining industry are determined by world market prices paid for gold. Low prices are usually reflected in the industry through worker lay-offs. Employer hostility to unions means that workers in new mines are sometimes denied the occasion to exercise their right to freedom of association ${ }^{5}$. The union front has been marked by violent conflict between members and their leadership (Crisp, 1984). The most recent was in 2005 when workers at the largest gold mine, Obuasi (now Anglgold Ashanti), dissatisfied with the outcome of wage negotiations attacked their leaders resulting in union fragmentation. A new union, General Metal, was formed. Union leaders interviewed attribute the situation to a breakdown in communication and have instituted measures to attract and retain members. Mining is a male dominated affair thus females constitute about $3 \%$ of its membership. The emergence of a rival union has compelled the union to devise activities to retain its core membership. In 2000 the only female ever to be elected as secretary to the largest branch union of the GMWU was interdicted under controversial circumstances that nearly broke up the union.

4. Formed in 1935, the Ghana Private Road Transport Union (GPRTU) joined the GTUC in May 1967. It is unique in the sense that its members are located within the private informal economy. As a result, its structures and activities deviate from traditional trade unionism. Its members are drawn from the private informal transport sections and are made up of vehicle owners, self-employed owner drivers, employee drivers, porters and union guards. The GPRTU's unique form is revealed in the fact that it is the only national union with no collective bargaining functions. Its main functions revolve around the regulation of the conditions under which its members provide transport services to the travelling public and financial aid to themselves. The union also engages in welfare provision, providing donations to support members during social events that mark rites of passage like funerals, weddings, engagement and naming ceremonies. ${ }^{6}$ Its uniqueness provides lessons for formal economy based unions operating in the informal economy. Fuel deregulation and introduction of the Labour Act, Act 651 that proscribed closed shop unionism has produced challenges for the GPRTU in terms of maintaining membership in the face of intense political manipulation to prevent the determination of transport fares by market forces. Transport fares in the private sector remain under the tight control of government with the compliance of the national leaders of the GPRTU and other transport operators' associations organised under the General Transport Coordination Council. The union is beset with splits and fragmentation. In

\footnotetext{
${ }^{4}$ Field notes, interview with union officers, 2007.

${ }^{5}$ Britwum A. O., (2007) explains how in 2005 Trapeg Company, prevented 2,000 workers in its employment from forming a union.

${ }^{6}$ Field notes, interview with union officers, November, 2007.
} 
some communities, there were as many as 17 private road transport associations operating. ${ }^{7}$ It still maintains its lead position in terms of membership size, influence and visibility. Irregular income that is characteristic of the sector means that only 15,000 out of 80,000 members are dues paying. It serves as an interesting case in providing peculiarities that traditional trade unions based in the formal economy do not possess.

5. The Maritime \& Dockworkers Union (MDU) organises employees of Ghana's ports and harbours, shipping, clearing and forwarding agents, as well as fishing and water transport enterprises. It has also faced several challenges of internal democracy and its history since it was formed in 1958 has been rife with membership splits and forceful removal of its leadership from office. ${ }^{8}$ Port activities, before the introduction of SAP, were managed by the state owned Ghana Ports and Harbours Authority. Its workers then had permanent employment. Economic restructuring privatised most port operations. Under the current globalised neoliberal framework, the tendency is for the state to relinquish direct provision of port services and assume limited oversight responsibility by collecting rent from private operators who provide port services. This has called for more private participation in port operations in Ghana with the preference for foreign operators who infuse high levels of technology forcing a reduction in human labour. The result has been retrenchment and the attendant loss of union membership and casualisation of stevedoring workers.

The MDU, together with some private companies, has set up a company the Ghana Dock Labour Company (GDLC) to provide employment for casualised dock workers. These workers are members of the union. The GDLC had 4,800 workers from 2002 to 2006. With mechanisation of port services and the ceding of 3 out the 12 berths to the Meridian Port Services in 2007, the workforce size has reduced to 3,000 as at the end of the third quarter of 2008. The MDU has an interesting mix of public, private sector workers and a large casual employee membership. The striking feature of this union is the adoption of the role of an employer to retain members and improve union financial base.

6. The Industrial and Commercial Workers' Union (ICU) disaffiliated from the GTUC in 2005 and has been through murky leadership struggle since 1992. It took a court action in August 2007 to remove the General-Secretary at the centre of this leadership struggle from office and secure some semblance of calm

\footnotetext{
${ }^{7}$ Field notes, interview with PIRO Ashanti Region, June, 2008.

${ }^{8}$ In 1979-1980 the afloat sea workers broke away to form the National Union of seamen. In April 1988 its leadership was forcefully removed from office, arrested and detained in police custody for 24 hours. At the time of field work, sections of its members were working at breaking away to join a rival union the National Union of Harbour Employees.

${ }^{9}$ Interview with union leaders, February, 2008
} 
within the union leadership. ICU is in the process of restructuring itself to elect substantive leaders, improve leadership/membership contact and amend its constitution. Next to GAWU, the ICU has a substantial informal economy membership, most of whom are women. Its framework for incorporating informal economy members into union structures is also elaborate.

The membership of ICU is drawn from a wide range of sectors like manufacturing, service, finance and hospitality. The ICU has a large membership and held $20 \%$ of GTUC membership. It is sometimes referred to as a mini-confederation. Its large size has been both a bane and blessing. Its resource base is better than most unions. However, internal cohesion has proved difficult to sustain, making the holding of quadrennial delegates' conferences problematic. In the years 1995, 1999, 2003, and 2007, conferences were put on hold, by court injunctions brought on by union staff or leaders. It is involved in several law suits. One third of cases in the law courts border on internal democracy, indicating weakness of internal structures to deal with membership discontent ${ }^{10}$.

Though disaffiliated from the GTUC, it still maintains its office in the Hall of Trade Unions. The general feeling during the field work was that ICU would return to the GTUC fold once the case sent to court by its ousted General Secretary, Kpoh, has been resolved to permit the holding of a proper Quadrennial Delegates' Conference. In January 2009 the deposed General Secretary sought to have the interim chairperson arrested for contempt of court for holding a Delegates' Conference. The case was thrown out of court on the explanation that the conference had convened to review union policies and not to elect officers. Such events make the ICU a peculiar case in the study of union democracy, first, within the national movement itself and in terms of national union relations with the union confederation.

The national unions were selected based on their peculiar challenges in the face of the economic restructuring and neo-liberal reforms resulting from globalisation. In terms of their historical background these national unions have peculiar problems with internal democracy which continue to plague their operations and dictate union response to the challenges of globalisation. Their strategic choices therefore should serve to first deal with the challenges of globalisation and secondly with internal cohesion so critical for positive union renewal outcomes.

\subsection{CHOICE OF UNION STRATEGIES}

Having determined the national unions that should form the case for study, the next task was to establish some criteria for the selection of union strategies for investiga-

\footnotetext{
${ }^{10}$ See Activity Report to the seventh Quadrennial Delegates Conference of the ICU
} 
tion. The usual focus of union revitalisation studies has been to explore the efficacy of union choice of renewal strategies, examine the robustness of their implementation and unravel outcomes (Turner, 2004). The tendency has been to study specific strategies depending on the interest of researchers. Union organising and gender democracy have been strategies that have received attention in single strategy focused studies. So have union organisational efforts in the informal economy. This study however sought to investigate union strategies not in terms of revitalization outcomes in the multi-dimensions of union power resources, but the implications of renewal strategies on union internal governance in areas that Behrens et al. outline as 'democracy, representation and participation' (Behrens, Hamann, \& Hurd, 2004a). This called for interrogating strategies that have direct impact on union internal structures.

The interest was on strategies that sought to address representation and participation of various sections of the trade union membership. Though strategies may target internal structures of unions, they may end up weakening membership positioning and so call for further review and re-strategising. Thus strategic options dictated by choices unions make to address external challenges can alter internal conditions for union membership.

The grouping of the strategies GTUC and its affiliates was based on the categorisation of union strategies by Turner (2004) as well as Frege and Kelly (2004). They group union strategies into six categories. These include organising, restructuring or reforming union structures, political action, labour partnerships, coalition building and international solidarity (Kelly \& Frege, 2004; Turner, 2004). Initial key person interviews with union leaders and their representatives revealed that union strategies of the GTUC and its affiliates fell into three broad categories: organising to expand or maintain union membership, internal restructuring of trade union structures and political action. ${ }^{11}$ As indicated, the study focus was on how strategies impact power dynamics within unions. Behrens et al's union power dimensions proved a useful framework for the selection of such strategies (Behrens, Hamann, \& Hurd, 2004a). It became necessary however to incorporate power relations by falling on the assertions of Fairbrother and Lambert about the need for unions to build alternative power base through their strategies and how the extension of union functions to connect workplace and community provide the key for union survival (Lambert, 2002; Fairbrother, 1990). The institutional vitality of unions is their most important power base for ensuring revitalisation success. A weak institutional vitality can severely undermine whatever power gains a union has, no matter its size, economic bargaining power and political influence. Strategies which directly impact union institutional vitality in terms of membership representation, union effective-

\footnotetext{
${ }^{11}$ Chapter four gives a full account of the strategies of the GTUC and its affiliate national unions.
} 
ness and relevance in ways that allowed connection with workplace and community became the obvious choices.

Three strategies stood out in terms of their implications for union representativeness, effectiveness and relevance from the list of strategies that unions were pursuing. ${ }^{12}$ They were an extension of union coverage to informal economy workers and groups, female union participation and representation as well as in the revamping of the consultative structures of the GTUC and the national unions. The consultative structures, the District and the Regional Councils of Labour (DCLs and RCLs), link the GTUC with the national unions. For the national unions, the locals were their membership holding structures which gave them their power base in the workplace and as well as the community. All three strategies were focused primarily on providing more space, and enhancing union relevance to specific membership groups in the unions. These strategies, in addition, highlighted the heterogeneity of union membership and the tensions produced for unions as they strove to respond to members from diverse locations and interests.

\subsection{DATA GATHERING PROCEDURE}

Data gathering was conducted at two levels. The first aimed at providing an overview of the general situation of the GTUC and the national unions and the second to gain answers to research questions about the implications of strategies for internal union democracy. Data gathering began with key person interviews of leaders of the national unions and the GTUC as well as heads of the specialised departments. Preliminary data gathering provided useful insights of union situation and strategic choices. Information gathered was used to determine the final choice of union case strategies and national unions. After having selected the case study units in terms of national unions and strategies the next step was to determine sources of information and the methods for collecting information from the sources identified.

The renewal strategies chosen, as explained above, were those that were directed at expanding and maintaining three distinct groups of union membership. These were the traditional members who have always been with the unions located in the formal enterprises in the local, district and regional union structures, the female union members in the union organs for promoting gender democracy and the informal economy workers. In attempting to unravel the implications of union strategies for internal democracy the research was interested in information about members' sense of union ownership, their operational space within union structures, the sites and targets of their struggles as well as power tools available for confronting these struggles. It was necessary to outline union structures and mode of operation in

\footnotetext{
${ }^{12}$ See chapter four for more details
} 
connection with these three distinct groups as well as the historical connection with unions.

The main sources of such information were located within the structures that these members engaged with their unions that is the women's organs at the national, regional and district levels, informal economy groups covered by the national unions and the GTUC, the regional and district structures of the GTUC as well as workplace based local unions of the selected national unions. The specific persons targeted in these structures were their leaders; local union executives, district and regional executives, executives of women's committees and informal economy groups covered by the unions. Others were executives of selected splinter unions. Regional officers of the selected national unions also served as sources of information for the study. Information was also gathered from union documents like constitutions and bye-laws, policy documents, reports, minutes and memoranda.

The main data gathering techniques were individual and group interviews, nonparticipant observation and document review. The procedure has been described as methodological triangulation (Flick, 2007). Gathering information from several sources using a number of research methods reduces bias, increases accuracy and strengthens the internal validity of the research results (Flick, 2007). Group and individual interviews were conducted using semi-structured interview guide. In a situation where the circumstances within and outside the case unions being studied were in a continuous flux, structured instruments would have missed events that were shaping union context. These instruments were designed to capture information on union challenges and strategies and changes in union membership, jurisdictional and power dynamics. At the regional, district, branch and local levels, data gathering efforts targeted information on membership concerns, modes of articulating membership issues within union structures and vehicles for engaging union policies and direction. Other issues covered by the data gathering instruments were information about locals' perception of union relevance and expectations of their unions. In investigating the gender dynamics of unions, information gathered in the interview sessions covered the meaning of union membership for women, and the ability of their unions to meet their expectations. Information was also collected on the functioning of women's structures within the union and modes for articulating women specific issues within the unions. The nature of the space women's structures occupy within the unions was also investigated in the study. For interrogating informal economy representation within the unions, data gathering targeted information on group profile and members' concerns, motives for seeking union membership and the benefits so far derived. The nature of union affiliation, and union activities in which group members were involved-all formed the subject of information gathering.

Union documents in the form of administrative documents like memoranda, minutes of meetings, letters, conference and congress reports, study and evaluation 
reports as well as newspaper articles were particularly useful in providing background information as well clarifying events that have shaped union experiences. Attending events such as union conferences and meetings enabled the observation of union power dynamics, opportunities for debating, union informal hierarchies, information sharing modes as well as the empowering potential union space offered membership during interaction.

The selected unions were covered in six out of the 10 Administrative Regions in Ghana. These were the Ashanti, Central, Eastern, Greater Accra, Northern and Western Regions. In each region, group interviews were held with executives of local unions, women's committees and informal economy groups. The data gathering on local unions and women's committees were restricted to the six selected national unions discussed above. That for informal economy coverage was more extensive, and involved all active informal economy groups affiliated to the national unions and the GTUC. Group interviews were also held with executives of RCLs, Regional Women's Committees and DCLs in two districts of each of the six selected regions. The study also covered individual General Secretaries of fifteen national unions, some heads of the GTUC's specialised departments, Gender and Informal Economy Desk Officers of the GTUC and national unions. ${ }^{13}$ Executives of the rival labour centre, the Ghana Federation of Labour (GFL) and officers at the Ghana Labour Commission were also interviewed. The Brong Ahafo and Upper West regions were covered specifically on the insistence of national officers of GAWU who explained that any information gathered on its rural self-employed groups would be skewed if three groups in these two regions were omitted from the study. The total number of individual and group interviews conducted was 208 ${ }^{14}$. All interviews were recorded by note taking. Where research participants granted permission, the interviews were recorded on tape. The taped information was later transcribed and used to supplement the written notes.

\subsection{ANALYTicAl PROCEDURE}

The analytical procedure for deriving meaning from the information gathered through the research adopted both the nomothetic and ideographic approaches. They allowed for outlining the general and peculiar features in union situation. The general level was the GTUC as a confederation of national unions which share similar experiences originating from the overarching global and national economic environment that shapes the labour market and its corresponding industrial relations framework. At this level, the common context of the national unions as members of one confederation was explored in addition to how various time line features like the historical trends in state/union relations as dictated by economic policies have

\footnotetext{
${ }^{13}$ See Appendix A for the list of research participants covered in the study

${ }^{14}$ Appendix A provides the background, national union origins as well as regional location of research participants
} 
shaped union existence. Ideographic analytical approaches become necessary in identifying differences within national unions generated by their sector specific situations emanating from the variations in terms of the intensity of liberalised globalised policies. There have been different degrees with which the various industrial sectors have attracted FDIs, for example, or the specific globalised trend shaping union challenges like deregulation or liberalisation. Differences exist in terms of how production forms have changed and infusions of improved technologies have occurred. While gold mining and construction have attracted more foreign participation, poultry and rice farming has been attacked by dumping through liberalised trade, depressing agricultural production in these areas. Fuel deregulation serves as a big challenge for the transport industry. Even within sectors, global penetration has been uneven. Thus, in the case of agriculture, oil palm, rubber, exotic fruits and lately bio-fuels have been drawing in FDI in various forms, while cocoa and food crop production remain as peasant production forms. Working conditions and national union specific situations varied as a result calling for differences in the mix of union responses and their corresponding impact on union membership. It is by looking out for peculiarities that differences could be unravelled.

Data analysis was incorporated into the field work. Interview notes were edited at the end of each day and, where necessary, follow-ups were made. Some amendment to data gathering and respondents selection that became necessary as a result of daily editing and coding, was the inclusion of regional field officers of the national unions known as Industrial Relations Officers (IROs). The initial selection of research participants excluded these officers. They were represented initially as administrative officers in union structures and did not appear as influential in union decision-making structures. Their connection with the three membership groups was also not evident. Once in the field however, interview sessions and the interactions with union officers at the regional and other sub-regional levels revealed the key role of IROs within the union governing structures at the regional and district levels. In the regions, they were the contact between members and their national union structures; and, though regional and branch officers, according to the constitution, had more power within the union structures, in practice IROs were very powerful. IROs had more knowledge of their unions and industrial relations practices than their members and in several instances had better contact with the members than the elected officers. National union officers rely on IROs to get access to their local unions in the regions. This made the inclusion of the IROs in the research crucial for clarifying union situation and for receiving feedback on the information gathered.

The information derived from daily editing was used during feedback and validation sessions with research participants to discuss emerging trends and to clean the data of inconsistencies. The specific analytical organising devices used to derive meaning from field data gathered were codes. Coding was done using the three stages outlined by Gibbs: open, axial and selective coding (2007). Daily editing pro- 
vided the occasion to begin open coding through, as Gibbs directs, a reflective reading of field notes to identify relevant categories for the development of analytical themes. Open codes were used to develop themes for comparisons, establish trends within union events and experiences and search for significant events and experiences. Later categories identified were refined in the light of study questions and objectives. The final level selective coding involved the development of central categories to tie all the related themes together.

The outcome of the various levels of coding exercise was the explanatory devices, the categories and themes that were used to organise the information gathered for writing the thesis chapters. These were:

- The conditioning factors:

○ The factors conditioning trade union experiences;

- Determinants of trade union agenda;

- Union strategies as intervening conditions;

- Implications of strategic choices for internal democracy:

- Union internal and external context;

- The notion of union membership;

- Struggle sites and targets;

- Power tools, nature sources;

$\circ$ Empowering and Constraining factors.

Information generated around these themes was useful in identifying general and unique cases as well as limits to differences or similarities. The application of the themes was altered for the various strategies under interrogation in this work. Each empirical chapter therefore carries an explanation of its own specific organising devices as related to the dynamics of peculiarities that qualify the various forms of union membership.

\subsection{EMERGING ISSUES OF RESEARCH QUALITY}

The case study, even though hailed as most appropriate for conducting a study of this nature on trade unions, is beset with problems that have the tendency to compromise the quality of the data gathered. These are the usual issues of reliability, the extent to which the information gathered accurately reflect the situation that was investigated. Others are validity, accuracy of explanations derived from the information gathered and the extent to which such explanations can be generalised to cover similar situations. The use of semi-structured instruments and the reliance on interviews, for example, posed challenges for regulating reliability and validity. There were concerns for confidentiality and anonymity in a situation where employers were nervous about bad publicity and union executives anxious to protect their jobs especially at the local level. Another group of respondents who were vulnerable were employees of the national unions, especially the regional officers and 
the IROs. Entry into the research setting in the regions and districts was facilitated by national union leaders and regional officers. This produced its own challenges even though it eased access to union executives at the regional, district, branch and local level. The use of the tape recorder was rejected by some research participants as a result of insecurity and the fear that recordings might fall into the wrong hands. In several instances however membership frustration was so high that workers and union executives were beyond fear and allowed the use of the tape recorders with some insisting that they wanted their views passed on to their national leaders unedited. In presenting the results, attempts have been made to protect respondents, especially union staff and local union leaders who are most vulnerable, by rendering them anonymous. Union situations are discussed in broad terms and local identity, where there is no permission for disclosure, suppressed.

A major limitation of interview data quality is the reliability of mind recall, the sensitivity of information being sought and the effect of the research context on interview responses. The interview questions sought to determine inter and intra union situations and research participants were in some instances hesitant about revealing underlying issues that bordered on their relations with their union officers, posing real difficulties for accuracy of information provided through such interviews. This limitation was countered through the use alternative information sources like union documents and interview with leaders of rival unions outside the GTUC. Such precautions notwithstanding, there was also the background of the researcher and the high possibility of bias in interpreting the qualitative data collected. The debate about researcher neutrality in social studies research has travelled several trajectories coalescing to an increasing acceptance that '...it is futile to try to eliminate the effects of the researcher, we need to understand these effects and monitor and report them' (Gibbs, 2007, p. 92). There was an attempt however to monitor researcher misinterpretations and bias through feedback sessions with research participants. A major form of this feedback session was a results-validation workshop in January, 2008, where union leaders and informal economy members discussed preliminary research results.

The main forms of quality control therefore had been the use of methodological and respondent triangulation and checking data interpretation with the research participants. Though these procedures are not foolproof they provide some level of quality control. George and Bennett underscore the importance of triangulation to for checking 'personality biases that stem from single methodologies' (George \& Bennett, 2005, p. 41). Again Gibbs notes that triangulation and checking data and its interpretation with participants can be used to avoid research errors (Gibbs, 2007). The final interpretations of research finding were conducted to reduce to the minimum the known shortcomings of the case study approach. 


\subsection{SUMMARY AND CONCLUSION}

This chapter has covered the process for gathering and analysing data. It has provided the specific context of the research, its focus and goal were. As explained, trade union research has been dominated by the case study approach for several reasons. The most important being the nature of events being studied. The fluidity of union processes and the lack of tools to hold them in check to warrant effective accounting of causal factors have led to a reliance on case studies. Among the attraction to the case study approach for this research was the possibility it provided for detailed study of individual cases of social objects while conserving their unitary character. The flexibility in the selection of cases however imposed elements of bias that threatened the validity and reliability of findings. Selectivity of cases also meant that generalisation of research findings were severely limited. The use of multiple methods served as a tool for overcoming research methodological shortcomings that could compromise research outcome.

The GTUC had presented itself as an obvious choice for study because of its predominance on the Ghanaian labour scene and its historic role in the defence of workers in Ghana. Five of its national affiliates and one member which had recently disaffiliated were purposively selected based on the industrial and economic sectors in which the majority of their members were drawn and the intensity of challenges posed by globalised economic policies. With the exception of the GPRTU the selected national unions were either predominantly based in the private sector or had a mix of private and public sector workers as their members. The three strategies selected for study were those that dealt with three distinct categories of union members: women, informal economy groups and union members in union structures at the local, district and regional level. These strategies therefore had direct impact on union representation, participation and internal coherence because of the distinctiveness of each of the membership groupings that they were directed at.

The study sought information about members' ownership of their unions, their spaces in union structures, nature, site and targets of membership struggles, as well as sources of power tools for engaging such struggles. The information gathering methods were key person interviews to outline union challenges and strategic choices, and to guide the selection of national unions and the specific renewal strategies for study. The main body of information was provided through group and individual interviews, document reviews and observations at union events. Research participants included executives of women's committees of the GTUC and the national unions, leaders of informal economy groups affiliated to the national unions and the GTUC, executives of DCLs, and RCLs as well as local unions. National officers of the unions as well as union staff at the headquarters and in the regions were also interviewed. The research was conducted in two selected districts of six out of the ten regions of Ghana. 
Data analysis involved daily editing and feedback to eliminate inconsistencies and validate emerging trends and outstanding cases. Organising data to draw out meaning was done through three levels of coding-open, axial and selective. This allowed for generating descriptive categories, explanatory devices and analytical codes. These were used to distil factors conditioning trade union experiences and the determinants of trade union agenda, their implementation approaches and the implications for union internal democracy. The application of these organising devices to the various strategies was altered to suit the peculiarities of issues underlying their implementation in the chapters that follow.

The case study, despite its suitability for research of this nature on trade union internal democracy, has its shortcomings in the form of data reliability, and interpretation biases. These were countered by methodological and respondent triangulation. Data checking with research participants was used to enhance the reliability of data gathered and validity of interpretations. 

Chapter 4

UNIONS STRATEGISING FOR RENEWAL 


\title{
4 UNIONS STRATEGISING FOR RENEWAL
}

\begin{abstract}
Globalisation challenges operate in various sites and through several policies to undermine union effectiveness, relevance and legitimacy. These include major policies like privatisation, deregulation of prices especially fuel and utilities, liberalisation of trade, industrial relations legislation and institutions as well as the flexibilisation of employment terms and conditions. The mix of renewal strategies adopted by the GTUC and its national unions focused on strengthening membership power through the expansion of the membership base and a restructuring of union structures, shape and processes. Policy engagement, coalition building with labour organisations and NGOs were the additional strategies that involved agents external to the unions. The direction of strategies adopted by the GTUC and its national unions recognises the importance of membership power in union revitalisation. The strategies give little indication of how unions intend to deal with the broader principles underlying the globalised production systems which they identified as shaping the current terrain in which they operate.
\end{abstract}

\subsection{INTRODUCTION}

Work's assertion that the direct experience of globalisation for most people is in the area of production, is an apt rendering of the experience of organised labour in Ghana (Work, 2002, p. 47). Labour has borne the brunt of the neo-liberal policies that have given corporate entities their power and influence in the globalised economy (ibid). Chapter Two noted how restructured production relations informed by neo-liberal policies underlying globalisation altered notions of development from production for the satisfaction of national needs to production for external markets. Labour's fortunes shifted when its position as a market stimulant was reversed. Under neo-liberal economic systems, labour, a drag on corporate competitiveness, loses the sheltered position accorded it in the pre-economic adjustment era (Work, 2002; Önder, 1998). Union concerns are no longer public interests. The exaggerated importance accorded corporate profit within economic growth served to strengthen employers to the detriment of labour. Decision-making institutions and organisations operating at the workplace, nation state, regional and global institutions serve as vehicles for promoting corporate interests over labour (Turner, 2004).

The effect of changed conception of production and production relations on workers and their organisations have been the subject of several studies on union decline. Such studies have noted the impact of workplace restructuring on dwindling union membership as well as loss of union effectiveness and relevance. Currently research 
attention has shifted to union renewal (Fairbrother, 1990) or revitalization (Turner, 2004) to examine how union strategies have succeeded in reversing membership decline. While some have concentrated on single strategies others have compared multiple strategies in different national locations (Harrod \& O'Brien, 2002; Work, 2002; Hyman, 2001; Fairbrother, 1990). The general conclusion is that far from being doomed to extinction by globalised induced work restructuring, unions are beginning to secure complete resurgence. Some have stalled membership decline others have made dramatic reversals to their fortunes by securing growth in membership (Voss \& Sherman, 2000).

Increasingly, union revitalisation studies focus on strategies that unions have adopted to reverse decline, highlighting successful efforts and examining conditions that determine the outcome of union strategies (Voss \& Sherman, 2000; Harrod \& O'Brien, 2002). This chapter explores strategies that the GTUC and its national unions have adopted to reverse decline. The information used in the chapter was derived from key person interviews with General Secretaries or their representatives of the national union affiliates of the GTUC and the ICU15. The Union of Industry, Commerce and Finance Workers (UNICOF) was the only union not covered. ${ }^{16}$ The Secretary-General and the deputy Secretary-General as well as the heads of Organisation, Education and Research and Policy were interviewed. The interviews conducted in the months of October to December 2007 provided information on union challenges and the strategies for countering these challenges. The chapter begins by providing a background for assessing union strategies in Ghana with an examination of the specific nature of union challenges as captured by their leaders. The chapter is guided by Work's declaration on the need to explore the experiences, interpretations and contestations of globalisation by various sections of society particularly in the context of organised labour (Work, 2002, p. 47).

\subsection{UNION CHALLENGES}

Union challenges refer to the situations that weaken union ability to defend their members and threaten their very existence. While some challenges act to diminish union size and influence, others impact union functions and undermine the very notions on which trade unions operate. Union challenges vary not only in nature, but operate in several sites. The workplace, the labour market, state policy orientation and international institutions and organs are the major sites of contestation for union survival. According to Harrod and O'Brien

...organised labour faces challenges on multiple levels of organization and activity. At the workplace, new methods of production and management control threaten job security and working conditions.

\footnotetext{
${ }^{15}$ See Appendix A for a list of key National Union officers covered and the unions from which they were drawn.

${ }^{16}$ UNICOF was formed from a splinter group that broke away from ICU in August, 2003. It was registered as a Trade union in October of the same year and launched in March, 2004.
} 
At the state level, a commitment to economic liberalism and rising political power of corporations has reduced the utility of the state for worker organizations. ...institutions and practices that sit above the state region pose challenges to organised labour. The WTO binds state policy while IMF and World Bank influence national political economies by promoting liberal forms of structural adjustment. (2002, p. 26)

Driving globalisation are policies that seek to increase labour productivity while curtailing the right of workers to protection and a fair share of the fruits of their labour (Harrod \& O'Brien, 2002). State policies are directed at dismantling labour laws in an effort to reduce employment protection and social wages. At the international level, liberalisation clauses and deregulatory provisions pushed by superstate organisations like the IMF, World Bank and the WTO all lend strong support to corporate powers at the expense of labour (Harrod \& O'Brien, 2002; Munck, 2002; MacInnes, 1990). Such provisions filter down from the regional and sub-regional bodies like the European Union (EU), African Union (AU) and the Economic Community of West African States (ECOWAS) to nation states like Ghana.

Labour market restructuring involves recourse to precarious employment types like outsourcing, sub-contracting, and part-time work thereby promoting labour market expansion in sectors where union organisation is least effective (RoyChowdhury, 2003; Fairbrother, 1990; MacInnes, 1990). In the workplace the lines between management and the workforce is redrawn under a participatory and consensus oriented management philosophy that gives workers some semblance of a shared vision in corporate goals and ideals while collective bargaining norms are altered to limit the scope for institutionalised negations (RoyChowdhury, 2003, p. 38). Management efforts are directed at preventing the default mode of unions from operating in order to secure a more acquiescent labour force that is easy to manipulate (Harrod and O'Brien, 2002; Fairbrother, 1990). Labour market and workplace restructuring affect union membership growth outside its traditional domain while its effectiveness in workplaces where it is already organised diminishes (Lambert, 2002).

Workplace changes and employment restructuring are not confined to the private sector alone. Public sector reforms supported by an increased emphasis on efficiency, competition, discipline and productivity have affected state welfare provisioning and undermined social wages. The withdrawal of the state from direct involvement in production redefined relations between nation states and trade unions (RoyChowdhury, 2003, p. 23). The resulting impact of the erosion of union leverage over the state and employers has been felt beyond the loss of their numerical strength to cause shifts in the internal dynamics of unions (RowChowdhury, 2003). It is in this context that unions have sought to reverse their fortunes through a variety of renewal strategies. 


\subsection{UNION CHALLENGES IN GHANA}

In Ghana union challenges have come in all the forms outlined in the literature on union fortunes under globalisation. International non-state organs served as the main conduits for the introduction of neo-liberal policies. Earlier chapters have discussed how the introduction of structural adjustment in 1983 became a turning point in the fortunes of organised labour in Ghana. Before the 1980s union challenges were underscored by its relations with the state dictated by the general performance of the national economy as well as the political economic orientation of the government in power (Britwum \& Martens, 2008; Britwum, 2007). The position of the GTUC as the most organised social force and the strategic location of its formal sector members placed it at the centre of the Ghanaian political landscape (Britwum \& Martens, 2008). Its role in the overthrow of colonial rule has been well documented (Adu-Amankwah \& Tutu, 1997; Panford, 1996; Jeffries, 1978). Its political visibility resulted in chequered relations with the state ranging from a favoured position under the CPP regime of Dr Kwame Nkrumah to hostility from the military regimes of the NLC that overthrew the CPP and its civilian successor, the PP. Hostile acts ranged from shooting to kill striking workers, arrests and detention of vocal union leaders. Less violent acts of hostility included manipulation and cooption of union leaders to control union actions and response to state policies. Friendly governments, supported the growth of the GTUC with gifts of physical assets, and supportive labour legislations (Britwum A. O., 2007). The Industrial Relations Act 299 ensured that for 57 years of its existence the GTUC was the only labour centre in Ghana ${ }^{17}$. Other provisions like the closed shop and check-off for deducting union dues absolved national unions of the responsibility to recruit or organise new union members.

Economic mismanagement in the 1970s under the military regime of the Supreme Military Council in its various forms (SMC I and SMC II) destroyed the national economy calling for draconian resuscitation measures ${ }^{18}$. Low commodity prices, fuel price hikes and natural disasters compounded the economic situation denying the PNDC regime a strong leverage in bargaining for state led home grown remedies. The invitation of the World Bank and the IMF to provide support for the ailing Ghanaian economy was therefore from a weak bargaining position. True to the nature of their operations, the IMF and World Bank dictated the framework and the Ghanaian government provided the details (Britwum \& Martens, 2008; Kraus, 1988). As usual Ghanaian workers bore the brunt of economic restructuring under the caption Economic Recovery Programme (ERP) instituted in two phases ERPs I and II (Britwum, 2007; Graham, 1989).

\footnotetext{
17 The passing of the Labour Act, 651 in 2003 introduced trade union pluralism ostensibly to bring Ghanaian labour laws in consonance with ILO's Conventions 87 and 98 on the freedom of association.

18 For accounts on levels of economic mismanagement and the state of the Ghanaian economy during NRC/SMC rule see Aryeetey \& Goldstein, (2000) and Shillington (1992).
} 
The period of economic adjustment from the mid 1980s to early 1990s is acknowledged by several writers as the longest period of acrimony between state and organised labour (Britwum A. O., 2007; Boafo-Arthur, 1999; Graham, 1989; Ninsin, 1989). The ERP I policy demands that impacted the Ghanaian labour market and subsequently working conditions were the devaluation of the national currency the cedi, a reduction in government expenditure and privatisation of state owned enterprises (Britwum \& Martens, 2008). Government expenditure reduction meant a curtailment of social wages through the withdrawal of subsidies on food, health, education, agricultural inputs, fuel and utilities, public sector wage freeze and the retrenchment of public sector labour force considered redundant (Britwum \& Martens, 2008; Aryeetey \& Goldstein, 2000). Additional policies in the second phase of economic adjustment, the ERP II, were trade liberalization and legislation to attract FDI.

The impact of economic restructuring on the GTUC has been documented in several sources owing to the pervasive effect on union size, structure and effectiveness (African Labour Research Network, 2004; Adu-Amankwah \& Tutu, 1997; Panford, 1996; Graham, 1989). Job losses from privatisation of state owned enterprises and public sector labour rationalization caused the GTUC to lose $40 \%$ of its membership in less than a decade (Britwum A. O., 2007). Trade liberalisation also caused further job cuts as private domestic enterprises folded up under liberalised trade, high interest rates and currency devaluation. Job losses were compounded by attempts by the GOG to suppress labour's resistance to economic restructuring and avoid paying due compensation to retrenched workers under intense pressure to meet World Bank and IMF demands. ${ }^{19}$ Economic restructuring served as a conduit for introducing the economic and political principles underlying economic globalisation into development planning in Ghana. The decision to access financial relief under HIPC further entrenched neo-liberal economic policies. Its accompanying development blue print, which in the case of Ghana were titled the Ghana Poverty Reduction Strategy Paper I and the Growth and Poverty Reduction Paper I (GPRS I and II) reinforced the neo-liberal framework (Britwum \& Martens, 2008).

The experiences of the national unions under ERP I and II as noted earlier were dramatic. Economic restructuring was devastating for the GTUC and its affiliates in terms of the reduction in membership size, effectiveness, relevance and legitimacy. The GTUC for example lost $26 \%$ of its membership to SAP in the 1990s (AduAmankwah \& Tutu, 1997). The rate of membership loss in 2008 had reduced but not stopped altogether. The dynamics of the labour market has altered, shifting the

\footnotetext{
19 The COCOBOD Retrenchment and Indemnity Law, PNDC Law 125 (1985) and the State Fishing Corporation, Re-Organisation and Indemnity Law, (1986) were legal instruments used to prevent the payments of compensation to retrenched workers (Britwum A. O., 2007; Panford, 1996).
} 
most energetic sector of the labour market from public sector to the informal economy. This has called to question the claim of the formal economy based GTUC as the mouthpiece of Ghanaian workers, $81 \%$ of whom are informal economy workers. Currently however union challenges due to globalisation only differ in terms of intensity. Sector specific policies and the level of exposure to global marketplace produce differences in the challenges that the various national unions face. The next sections examine some of these specific challenges identified by leaders as confronting their unions. These challenges underlie the strategies they have developed to restore union dynamism and ensure that organised labour remains relevant and effective in the defence of workers' interests against globalised capital.

\subsubsection{Privatisation and Work Restructuring}

The section above has outlined the international and national policy environment that constituted the conduit for the introduction of neo-liberal policies into the Ghanaian economy. The major challenges outlined by union leaders were those located within the national arena. They included privatisation of state-owned enterprises (SOEs), trade liberalisation, subsidy withdrawal and deregulation of energy and fuel pricing. Ghana before the introduction of SAP was second to Tanzania in terms of state participation in the national economy. As a result of the pro-socialist orientation of the first government after independence under Dr. Kwame Nkrumah, substantial proportion of the economic activity in construction, manufacturing, finance, services, and plantation agriculture were under state control (African Labour Research Network, 2004; Britwum \& Martens, 2008). Economic mismanagement rendered most of these enterprises unproductive making restructuring of SOEs a major focus of the ERPs in Ghana (Fine \& Boateng, 2000; Aryeetey \& Goldstein, 2000; Shillington, 1992).

A major challenge identified by all national union leaders interviewed was the effect of the privatisation of SOEs and the attendant job losses. ERPs I and II supervised a massive transfer of state assets to foreign private ownership. Unions most affected were ICU, GAWU, CBMWU, GMWU, MDU, CWU, NUS, PSWU, PUWU, TWU, and GTPCWU. Areas of massive privatisation were the maritime industry, where the entire fleet of Ghana's shipping line, the Black Star Line, was sold off and dock machines for ship-building abandoned and left to rot at the Tema harbour. ${ }^{20}$ Others were construction, plantation agriculture, manufacturing, mining and service provision. With privatisation, public sector based Ghanaian workers were exposed overnight to the stringent and lower working conditions that characterise the private sector. ${ }^{21}$

\footnotetext{
20 Interview with union leaders and officers of MDU October, 2007

${ }^{21}$ See also Fine and Boateng, (2000) for further details on economic restructuring in Ghana on public sector employment.
} 
Membership loss from privatisation was caused by loss of employment through retrenchment and relocation of workers out of the jurisdiction of unions through outsourcing. Companies' legal right to restructure and downsize after privatisation serves as a pretext to lay off workers in order to save costs. Secondly, the tendency to concentrate on core activities and outsource peripheral tasks to smaller companies moves workers outside their union jurisdiction and rid them of their union membership. Public sector based unions like TEWU, LGWU and HSWU faced similar challenges originating from a different set of policies that were focused on the curtailment of state expenditure through a reduction in government wage bill. Public sector labour rationalisation or down-sizing was used to reduce the workforce of a supposedly over-employed public sector ${ }^{22}$. Several workers were laid off from public educational and health institutions as well as local government services. Activities like sanitation and catering in tertiary institutions were also outsourced. Significant membership decline experienced by the case study unions include the ICU which lost between 90,000 and 80,000 members to SAP in the 1980s. Its membership now stands at 55,000 from a pre-SAP high of 130,000. GAWU's also suffered a dramatic decline and holds in 2009 47,000 of its 130,000 membership in 1980. The MDU's 1980 size of 25,000 has reduced to 15,950 in 2009, while the CBMWU holds a paltry 6,000 of its 22,000 members in the 1980 s, having dropped to 14,600 in the 1990 s. ${ }^{23}$

Union leaders contend that the rate of membership decline in 2000s has slowed considerably and the outright laying-off of workers to a large extent in 2008, ceased. Unions like TEWU and HSWU are set to grow however because education and health sectors which they cover keep expanding to meet the demands of population growth. The refusal to recruit new workers to replace those lost to natural attrition (death, retirement and resignation) however slows down the rate of membership growth. For the GMWU and PSWU privatisation was a mixed blessing, FDI infusion improved production technology and resuscitated the Ghanaian mining industry from collapse. The FDI boost also helped to improve the working conditions for workers in the older and well established mines. The flip side however, was job losses and the attendant membership reduction. As a result of the introduction of capital intensive technology, the membership of the GMWU dropped from 22,000 in 1987 to 10,000 at the end of 2006. GMWU lost 1,486 members in 2007, however, it gained members and in 2009 the GMWU has 16,000 members ${ }^{24}$. PSWU membership size of 45,000 in the late 1970 s has been reduced to 20,618 in $2007 .{ }^{25}$

Membership loss impact union resources and affect their ability to carry out their activities. Union leaders of PSWU and GMWU however explain that the threat to

\footnotetext{
22 (ibid)

${ }^{23}$ Interview with Deputy General Secretaries of CBMWU, MDU, ICU and GAWU, May 2010.

${ }^{24}$ Interview with Deputy General Secretary, GMWU, May, 2010

${ }^{25}$ Interview with Deputy General Secretary of PSWU, November, 2007.
} 
union finances from membership loss was initially offset by increases in workers' salaries. The skills needs of privatised enterprises that introduced new technologies demanded a workforce with higher qualification pushing up salaries and giving unions higher dues from members. But as technology gets increasingly modernised and the workforce needs keeps shrinking, it is only a matter of time that membership size will drop to levels where deductions are no longer able to sustain unions.

Privatisation impacted GTUC in several ways. First a fall in membership reduced its capacity to mobilise large numbers to back its political muscle and therefore weakened union strength and clout. As union leaders explain, GTUC's political clout was derived from its size and the strategic location of membership in key areas of the Ghanaian economy. Secondly, continuous retrenchment and restructuring focused union attention on negotiating severance awards to the neglect of other issues. Union leaders disagree with the strategy of cutting costs through worker lay-offs and insist that employers should devise alternative solutions to restoring company health without recourse to retrenchment.

Other national policies that caused unions to lose members have been work reclassification. The Labour Act, 651 bars workers in essential services from unionising. Immigration services and revenue collection agencies were classified as essential services and their workers therefore legally barred from joining trade unions. An attempt to hive off ports and harbour workers through the same process failed. In February 2009 the Supreme Court ruled that the Customs, Excise and Preventive Services cannot be considered to be security oriented service providers and as such do not fall under the category of essential services. This suggested that the workers were not barred by law from joining unions. It remains to be seen how this ruling can be translated to allow the affected workers to join unions.

Deregulation and liberalisation have introduced into Ghanaian corporate practices guest ownership of enterprises. Only Ghanaian nationals have the legal right to register ships in Ghana. However foreign companies desirous of exploiting the economic advantages offered Ghanaian shipping vessels, secure the compliance of nationals to benefit from this regulation. A guest owner who is usually the legal owner is in actual fact fronting for a foreign national. The MDU is particularly affected by guest ownership and the national leaders of MDU insist that shipping companies registered under the Ghanaian flag are to all intents and purposes foreign owned. Union leaders report that meetings with Ghanaian guest owners are characterised by several phone calls before a decision can be reached. They explain that 'Ghanaian management at our harbours are mainly agents not owners of enterprises. They have no mandate to make decisions, they have to consult owners who are not located in Ghana over the phone all the time during negotiations.' ${ }^{26}$ The

\footnotetext{
${ }^{26}$ Interview with MDU national leaders, October 2007
} 
phone calls are consultations with the foreign owners of the vessels. Once decisions are reached there are considerable difficulties securing compliance. Equally frustrating is the practice where ownership of corporations keeps changing. Enforcing and complying with union management agreements become problematic because of the high turnover of guest owner personnel. This has led members to conclude that their unions are ineffective or, worse still, that their leaders have been bought by employers or management.

Construction in Ghana is another industry that attracts foreign private participation, especially Chinese. Chinese dominance has been further facilitated by the Procurement Act that obliges GOG to open all construction contracts to international bidding. Chinese contractors, according to union leaders of the CBMWU, have doubtful employer ethics and refuse consistently to respect Ghanaian labour laws. According to the General Secretary of the CBMWU:

\footnotetext{
Chinese contractors have no respect for Ghanaian labour laws and they are hostile to unions; they come with union bursting techniques and want to pay ridiculously low wages even below agreed minimum rates in Ghana. They sack workers whilst union is in negotiation over wages. The Procurement Act allows Chinese to bring in their own nationals for construction contracts that they win. One such case is the construction of stadiums for CAN-2008; the Chinese brought in 1,400 employees, so the project did not provide jobs for Ghanaians. They also resort to sub-contracting to get round dealing with unions. The procurement Act is an attack on procurement process by globalisation to reduce government control over the award of contracts. ${ }^{27}$
}

Their competitive edge is low bids and since all other factor costs except labour are determined by the market, they resort to various ploys like indirect employment or subcontracting, to spend as little as possible on their workers. Other ploys include the importation of Chinese workers to help execute projects in Ghana, like the national theatre and, more recently, stadiums built to host the continental football championships in January and February 2008. Such practices mean that the construction contracts in Ghana do not translate into creating jobs for Ghanaians, and where they do, they are low paying jobs with poor labour standards and out of union domain. In a similar vein, union leaders of the CWU complained of absolute disregard for Ghanaian labour laws by foreign employers especially those of Asian origin. Very few bother to acquaint themselves with the tenets of the Labour Act, citing their inability to read English as an excuse. Union leaders complained that some enterprises have no pay structures or schemes of service. According to the national leaders of the CWU:

About $90 \%$ of the communication industry is private, with multinationals who have a different perception of labour rights and want to apply labour standards of their country of origin to Ghanaian workers. Most of such employers do not want to respect the country's labour laws, some enterprises

\footnotetext{
${ }^{27}$ Interview with General Secretary of CBMWU, October, 2007
} 
do not have pay structures, nor scheme of service; and most employers do not know/care about labour laws. Their main aim is to hire labour at the lowest cost possible ${ }^{28}$

In the words of one union leader, 'capital has combined with the state to marginalise labour; capital suppresses labour with state support and workers find themselves at the mercy of foreign owners who have taken over SOEs' ${ }^{2}$ The aim of such employers, union leaders explain, is to hire labour at the lowest cost possible, create insecurity and deny workers union protection.

The challenges of organised labour introduced by privatisation were the major cause of reduction in union membership either through direct job loss, or the movement of workers out of union ambit. Labour shedding has been motivated by cost cutting measures and efforts to make workers easier to manipulate. The latest means used to curtail worker power and further reduce labour costs is the adoption of different forms of temporary and indirect appointments like casualisation. Union leaders surmise that casualisation is a measure adopted by employers to get the same work done at a reduced cost. This form of employment is not the prerogative of private sector employers alone, state and public enterprises also resort to temporary employment to reduce labour costs. TEWU national leaders cited examples of the public universities that regularly employ temporal workers into permanent jobs. Other forms are contract appointment where employment agencies recruit workers for enterprises. Workers have no contractual relations with the owners of the enterprise where they work. The challenge this poses to unions is how to organise such workers and secondly where to organise them and how to define their employers. During field work, a visit to a construction work site in the company of the Central Regional IRO of the CBMWU, showed the difficulties facing unions in dealing with union members who are contract workers. When security workers complained about working conditions and equipment, the IRO had to resort to a phone call to the management of the employment agency outside the workplace who in turn had to call the management of the corporation at the worksite for explanation and redress. He could not engage directly with the management at the work site he was visiting since it had no contractual arrangements with the workers. If the workers were in the direct employ of the construction enterprise whose tasks they were executing, then the process for redress would have been less tortuous and the impact of union on the working conditions more directly felt. Management at the worksite explained that they had to resort to contract workers because of what they considered to be the interference of the union.

Some industrial sectors are more prone to the use of contract and outsourced workers. The construction industry and lately some manufacturing and financial institu-

\footnotetext{
${ }^{28}$ Interview with Senior Administrative Secretary of the CWN, October, 2007

29 Interview with PSWU national union leaders, October, 2007
} 
tions, like the Coca Cola Company and the Barclays Bank, have resorted to this form of work ${ }^{30}$. Plantation agriculture presents a peculiar case of the adoption of varying forms of employment relations to cut costs and distance enterprise owners and management from the workers whose labour they rely on. The process is achieved through forms of outsourcing, casualisation as well as small-holders and outgrower schemes that lead to a de-concentration of the workforce ${ }^{31}$. Enterprise expansion and increased production are achieved through shrinking the permanent workforce and expanding non-permanent forms of employment. The result is varying levels of informalisation, the dynamism of which is described in chapter five of this thesis. Workers are placed out of union reach, into sectors where they are difficult to organise.

Worker location in the labour market, their employment status and employment skills determine their accessibility to unionisation. The nature of work and security of employment that push workers out of union ambit affect worker reception of unionisation. Temporary and contract workers, because of their insecure employment status, are wary of joining unions especially where their employers are hostile. Most outsourced, sub-contracted or casualised employments are low skilled jobs. In industries like construction, stevedoring, wood industry and plantation agriculture, skills requirements are basic and employment status for workers temporal. Casual work serves as a refuge for the unemployed and poor working conditions mean that few regard it as a long term occupation. Worker turnover here is high and unions have difficulty keeping track of their members as a result. ${ }^{32}$

Unions are challenged in terms of how to organise temporal and contract workers, and once organised how to maintain their union membership. Unions organising in the construction, maritime and wood industries, CBMWU, MDU and TWU grapple with this challenge. Temporal workers on short-term contracts, even after unionisation, lose their union membership when the contract for which they were employed expires. When engaged on a new contract, the process of unionisation has to begin all over again irrespective of the fact that the employer might be the same. Because union operations are underpinned by collective bargaining, membership in a situation of high labour turnover becomes a big problem. Union membership is not transferable and each new construction contract calls for reorganisation of a local. The unionisation process can be long involving procedures that take months to fulfil. Union certificates for locals working under short-term contracts within the construction industry have been secured long after the contracts have expired ${ }^{33}$.

\footnotetext{
${ }^{30}$ Interview with the Client Relations Manager, Recruitment Reliance Services, February 2008

${ }^{31}$ Interview with Deputy General Secretary, GAWU, December, 2007

${ }^{32}$ Interview with General Secretary of CBMWU, November, 2007

${ }^{33}$ Interview with field officers of the CBMWU, November, 2007
} 
Temporal work contracts, indirect employment and casualisation transform the spatial existence of the work place forcing it to take on a fluid form, lengthening the contact between workers and the real employers who benefit directly from their labour. The work place is no longer confined to a specific space. This undermines the core ingredients for effective unionisation: solidarity, mobilisation and negotiation. The congregation of workers in one space over a period provides fertile conditions for developing a sense of belonging and a shared identity. Workers can easily gather in their numbers to defend a common cause. In a fluid work place with no identifiable employer who takes direct responsibility for the workers who provide the labour that builds the enterprise, negotiations become unwieldy and outcomes difficult to enforce calling into question union relevance and effectiveness. Workers quickly lose confidence in their unions, they become difficult to mobilise and individualism turns out to be their characteristic feature.

Another trade union challenge identified by union leaders interviewed was the survival of enterprises which have in turn affected the security of employment. National policies, like trade liberalisation and deregulation of fuel and utilities, they explained, have undermined the textile, transportation and agricultural industries. Unions like ICU, GPRTU and GAWU that organise textile, transport and agricultural workers have been engaging with government over trade liberalisation policies that threaten the livelihood of their members. In some instances GOG prefers to pander to WTO agreements at the expense of the interest of Ghanaians on whose mandate they are in power. Once such enterprises collapse, unions lose their members. In the case of GPRTU, union membership size has not declined, it is rather the reduction in members who are in a position to pay dues because they have jobs and earn regular incomes. Only 15,000 out of the 80,000 members were paying dues as at the time of data gathering ${ }^{34}$. Agriculture has been affected, specifically poultry and rice production, through the withdrawal of import tariffs that has encouraged dumping of cheap imports on the Ghanaian market. The textile industry has also suffered the same fate.

Union size is sustained through recruitment of new members and maintenance of old members. The most obvious union challenges are factors that cause union size to fall or restrict unions from expanding. In Behrens et al's dimension of union power resources, membership is identified as an important power resource that underscores political and economic power dimensions (Behrens, Hamann, and Hurd, 2004a). Union size increases union economic power by enhancing union bargaining strength. In a similar vein, union size can enhance union political power by boosting union leverage with employers and governments. Union size also has implications for its internal vitality, the most immediate being union resources. Membership subscriptions form the basis for developing union activities and pro-

\footnotetext{
${ }^{34}$ Interview with General Secretary of GPRTU, November, 2007
} 
viding services to union membership. Membership perception of unions depends on its satisfaction with union response to its needs and the benefits it derives from its unions. A reduction in union resources can impact negatively union's ability to serve its members thus producing a spiral of dissatisfied members and a reduced union vitality, low resources and further reduction of union ability to meet membership needs. Likewise, inability to produce the required muscle to back union demands can lead to more job losses and membership decline. As membership loss sets in motion the reduction of union strength, other measures discussed below come in to further constrain union power.

\subsubsection{Labour Legislation}

Labour legislation reforms culminated in the passing of the Labour Act, 651 in 2003. The supporting memorandum of the sector minister stated that the law was seeking to end the monopoly of the GTUC over trade unionism in Ghana and get Ghanaian labour laws to reflect the new dimensions of globalisation in labour relations. The Labour Act, he further elaborated, was to provide the requisite environment for the private sector to pursue its new functions as the growth engine of the Ghanaian economy (Britwum, Enu-Kwesi, \& Arkosu, 2006). The coming into force of the Labour Act has created enormous challenges for unions in Ghana in the area of union pluralism which has generated union rivalry and fragmentation.

The Labour Act, 651 brought an end to closed shop unionism and encouraged union pluralism. It pegs the minimum number of union membership at two persons. The union which covers the majority of workers has the claim over the bargaining certificate to negotiate for the workers. Union leaders find this provision absurd, explaining that for a government to peg union minimum membership at two persons at a time when corporations are merging to remain competitive, can best be described as a ploy to weaken unions in Ghana..$^{35}$

Union pluralism poses serious challenges for trade union unity because of the tendency to promote inter union rivalry. The practice among the national union affiliates of the GTUC has been to operate within some agreed jurisdiction with each union respecting some territorial limitations. Jurisdictional boundaries however, are vague thus some have sought to take advantage of the Labour Act's promotion of union pluralism and jurisdictional ambiguity to poach members. Notable examples gathered were the intense jurisdictional struggle between GAWU and the TWU. So intense was the struggle that it threatened to split the GTUC. It took a verification exercise by the Labour Office to ascertain which national union could claim the bargaining certificate for forestry workers. Jurisdictional struggles have been experienced between GTUC affiliates like the CBMWU and GMWU, CBMWU and MDU as well as the CWU and PSWU. Union leaders contend that membership

\footnotetext{
${ }^{35}$ Interview with CBMWU national leaders, October, 2007
} 
poaching has become a means for union expansion since it is easier to organise unionised workers than those who have never been members of a union. Alternatively some unions with weak organisational capacity wait for the better endowed ones to organise members, then use the jurisdictional encroachment clause to take over the locals. MDU's leaders explain that their reluctance to organise informal economy workers partly stems from their experience with the CBMWU over workers of the Keta Sea Defence Project. ${ }^{36}$

Union pluralism causes union fragmentation. The abolition of closed shop unionism allows two or more unions to operate within the same enterprise therefore erasing union boundaries. Locals split easily where workers are dissatisfied with their unions and there is no effort to engage union structures for redress. Unions outside the GTUC confederation also take advantage to encroach others' jurisdiction and poach their members. NUFEM is engaged in a struggle to gain bargaining certificate for workers of the GDLC who are unionised members of the MDU. National leaders of CBMWU accuse ICU of poaching its members after disaffiliation from the GTUC. ICU now covers construction workers within the Construction and Allied Workers' Union, a situation which would have been untenable if it were still affiliated to the GTUC. Ghana Federation of Labour (GFL) the second labour centre in Ghana has also moved into GMWU's jurisdiction organising mineworkers in Tarkwa. In the same vein the ICU organises agricultural workers.

Not all union leaders consider trade union pluralism a threat. Some believe that closed shop unionism promoted leadership complacency. The challenge trade union pluralism poses, they insist, comes in the form of a re-conceptualisation of union functions and organisational capacity. Unions in the past did not engage in serious membership organisation for expansion. Once enterprises, where their locals were based were recruiting workers, unions were assured of automatic growth in size. They are now challenged in terms of capacity to attract and retain members, a test of their ability to devise products for members beyond wages, through initiatives that will enhance their attractiveness to workers. While some national union leaders have set themselves to meet this challenge and consider trade union pluralism a wakeup call, others appear to buckle over, under the notion that the Act 651 was set out to break the front of organised labour.

\subsubsection{Public Sector Reforms}

Pressures from IMF/World Bank on the GOG to reduce wage bill has led to several versions of public sector reforms. All these efforts have been informed, supposedly, by the objective of making government machinery function more effectively and at a lower cost. Policy fall-out has been several right-sizing and downsizing. The resultant public sector labour re-deployment as well as wage freeze and subsidy with-

\footnotetext{
36 Interview with MDU union leaders, November, 2007
} 
drawal have already been discussed. Others included actions to either cut the cost of divestiture by reducing the size of severance awards or measures to renege on severance payments to retrenched workers of divested SOEs as well as the removal of ghost workers on government pay-roll. The payment of end-of-service benefits (ESB) made the cost of retrenchment very high. ESB payments were cancelled in 1991. Workers who had contributions were paid their due. ESB still remains a contentious issue among workers in Ghana, especially in light of payments that parliamentarians and the executive awarded themselves at the end of parliamentary terms in 2004 and 2008. Attempts to resolve the public sector wage burden have seen several salary reform initiatives which challenge the core function of public sector unions. Collective bargaining continues to be the most important service that unions in Ghana deliver to their waged members. Any action that destabilizes collective bargaining will deplete union control over bargaining and call to question its relevance to workers, especially, in the public sector. Union leaders interviewed were anxious about the implications of current reforms for trade union organising in Ghana.

Dubbed the first generation SAP, ERP in the 1980s proceeded on the assumption that the public sector was over-employed, and its wage bill took up a significant proportion of domestic revenue (Baah A. Y., 2006; Aryeetey \& Goldstein, 2000). Over $60 \%$ of state revenue goes into public sector wages, about $10 \%$ of GDP. Public sector workers constitute $45 \%$ of formal employees and number 600,000 out of over 8 million strong Ghanaian workforce (Baah, 2006). Initially GOG's attempt to reduce its wage bill to IMF/World Bank prescribed levels was achieved through a tight control over wage increases, wage freeze and re-structuring of existing wages under a wage reform scheme. The first public sector wage reform resulted in the consolidation of allowances like housing, health, meals, electricity and transportation into salaries making it impossible for unions to negotiate further cash benefits for workers. Salary consolidation, according to union leaders, cut out a range of cash benefits like leave, housing, transport and rent allowances from wage negotiations, making the outcome of collective bargaining uninteresting for members.

The second generation economic reforms of the 1990s were directed at a realignment of public sector pay with the relevant labour market pay in the country. The resulting pay reform policy framework, Ghana Universal Salary Structure (GUSS), aimed among others to:

- Ensure equitable pay for public sector workers;

- Standardised pay across public sector employees performing tasks deemed similar;

- Decompress public sector wages to attract and retain more qualified professionals;

- Minimise non-cash benefits and cash allowances (about 70\% of total salary in some instances), (Baah A. Y., 2006). 
The goals of GUSS were informed by the concern to attract and retain highly skilled workers who constitute a small fraction of public sector workers, while keeping government wage bill within limits. The initial top/bottom salary ratio which stood at 13:1 was widened to $28: 1$. The nominal salary increases that lower grade wages attracted failed to take the majority of public sector workers out of the below US\$2.00 a day poverty margin. The disparities in public sector wages were blamed on unions by the consultant (PriceWaterHouse) who cited two wage negotiation mechanisms, collective bargaining between unions and management as well as consultation with public sector workers' associations through the Public Service Negotiating Committees, as being too restrictive (Baah, 2006). A three year suspension of public sector collective bargaining was recommended to allow government the opportunity to correct pay disparities. It was no surprise that unions rejected GUSS and GOG had to resort to force and manipulation to implement it.

The period 1999 to 2003 saw yet another reform package, the Public Sector Management Reform Programme (PSMRP), this time backed by the formation of a Ministry of Public Sector Reforms. The key concerns still remained the burden of the public sector wage bill on government revenue and the inability of the public sector to attract and retain highly qualified personnel. The year 2006 saw the most contentious pay reform policy, the Selected Accelerated Salary Enhancement (SASE), that sought to pursue selective pay increases to push senior technical and professional public servants' salaries to levels enjoyed in the private sector through the consolidation and monetisation of allowances and benefits (Baah, 2006). The Civil Servants' Association (CSA) rejected this on grounds that it was discriminatory, threatening to embark on industrial action. Just like its predecessors the SASE failed to resolve public pay structure; and in 2007 a new reform was proposed this time under the notion of living wages. A Fair Wages Commission was set up under a Parliamentary Act to standardise all public sector wages and salaries under the Single Spine Wage Structure which was to evolve relativities for all forms of employment and reduce the huge salary disparities across the sectors. The idea is to get the Fair Wages Commission to deal with all wage issues, get wages to be non-discriminatory and to fall within the national budget. In addition, it is set to bring under one umbrella the numerous public sector enterprises which remain on different pay structures outside government control. While GOG keeps an eye on the national revenue and expenditure, GTUC together with other public based workers' associations insist that low paid public sector workers should get a better deal. It is the position of the GTUC that workers earn a living wage irrespective of the proportion of the national revenue or its share to GDP that the government wage bill takes. Union leaders find it untenable that public sector wages contribute to poverty in Ghana. They believe that if a higher proportion of GDP, say $12 \%$, is used on wages and public sector workers moved out of poverty, then the nation can generate a higher 
GDP base to promote growth. ${ }^{37}$ Job and remuneration relativities also remain contentious.

GTUC's participation in the negotiations around the Single Spine Salary Structure has been strengthened by its close collaboration with labour associations like the CSA and GNAT. Together with these associations it has been possible to engage the process earlier and prevent previous encounters where unions have come on board too late to make an impact. This collaboration according to national union leaders, has allowed several controversial issues to be reworked. However the common salary structure when completed will have implications for individual collective bargaining agreements for the sector unions. The Single Spine Salary Structure will further reduce avenues for public sector based unions to exercise their major function: salary negotiations. Union leaders insist that reforming public sector pay should not undermine collective bargaining agreements since they take on board other conditions of service, beyond salaries, that fall outside the ambit of the Single Spine Salary Structure ${ }^{38}$. While negotiations are ongoing with full participation of the GTUC, it remains with unions to devise appropriate strategies to retain their members.

\subsubsection{Perceived Utility of unions in the work place}

Whereas privatisation, liberalisation, deregulation and public sector pay reforms emerging from international and national policy sites constrain union performance, within the workplace, management practices and a general disinterest in trade unions from certain categories of workers affect the effective functioning of unions. Management or employer hostility to unions and worker complacency were the major challenges national union leaders mentioned as their greatest workplace concerns. Management and employment practices constrain union ability to defend workers raising questions about the efficacy of unions in the workplace. Management practices can undermine union relevance in workplaces where structures are put in place to facilitate worker management negotiations for work benefits outside union involvement. Union leaders observed increasing sophistication in managerial practices and a greater measure of control of management over industrial relation practices and labour legislations. This places management at an advantage over workers with lower knowledge of labour legislation. When workers fall on the wrong side of workplace rules and regulations they feel their union leaders should be able to offer them protection. They have difficulty accepting to face disciplinary action when they belong to unions. They interpret resulting sanctions they have to bear as failure on the part of their leaders and feel let down by union leaders. The worst case is when the resulting sanction is dismissal. Union leaders interviewed explained their dilemma when they have to agree with management to pronounce

\footnotetext{
${ }^{37}$ DCL and RCL meetings with National union leaders, April and May, 2008

${ }^{38}$ Interview with General Secretary of TEWU, November, 2007
} 
their members guilty. On the one hand they are there to provide protection for their members and, on the other, they cannot condone indiscipline.

Senior staff, white collar and young workers especially tend to find satisfaction with their working conditions and so do not see the immediate relevance of union membership. Union leaders insist that the initial attitudes of these categories of workers do not last since some have often turned to unions for mediation when they come into conflict with employers or their representatives. For union leaders, it appears as if attractive working conditions generate complacency among senior and white collar workers. Thus, the extremes of good and poor working conditions hinder workers' readiness to join trade unions. It does appear also that young trade union members' disinterest in trade union membership derives more from apathy and wrong perceptions of trade unions, than from satisfaction with working conditions. But whatever reasons union leaders assign to their inability to attract white collar workers, senior staff and young workers, these categories of workers remain a challenge to workers' solidarity at the workplace.

Retrenchment and redundancy, even though saves production costs in the long term, impose heavy short term costs in the form of severance payments. In several instances employers either resort to measures to reduce severance payments or avoid payment altogether. According to union leaders, some retrenched workers feel that their unions let them down on two counts: one, failure to prevent retrenchment and two, additionally inability to secure due severance payments. Such workers become very sceptical of union membership and discourage other work colleagues from joining unions. This was a challenge identified by union leaders of ICU, CBMWU, and GMWU in their attempt to extend coverage to workers in new enterprises.

The greatest workplace challenge outlined by union leaders stemmed from employer hostility where employers refuse outright to allow unions to organise workers at the workplace. Union leaders cited Chinese, Indian and Ghanaian employers among the most hostile employers. During interview sessions, union leaders and field officers enumerated several instances where they had been thrown out of workplaces where they had gone to organise workers. Some had been exposed to violence ranging from verbal and physical threats, to physical attacks. Where they encounter no such barriers employer hostility is turned onto workers who signed on to join unions. Such workers are forced by their employers to withdraw their names and some dismissed for daring to declare their intention to join unions. The process for getting approval to form a local union and acquiring the certificate to bargain on behalf of a group of workers is long, and workers who have signed on to join unions remain outside union protection during this period. Employers exploit this absence of protection to dismiss workers who front as leaders. Union inability to protect such workers cause a loss of confidence and the fear of incurring a similar fate discourages others to join unions. The CBMWU, GMWU and ICU were most affected. 
ICU leaders found employers in the hospitality industry, specifically hotel owners, the most guilty of such practices.

The external challenge outlined by union leaders stem from policy changes that restructure work and workplace relations putting to test union relevance and effectiveness. These challenges are further compounded by employer hostility and workers' disinterest in union membership. The GTUC and its national affiliates find themselves challenged to devise options for serving workers' needs beyond collective bargaining, and facing up to employer hostility and managerial sophistication. This calls into question union capacity for devising alternatives for sustaining membership interests and engaging employers' union bursting tactics. Union challenges however were not limited to external sources alone. In fact such external challenges have imposed their own strain on union capacity and internal structures. The section that follows discusses the internal challenges that union leaders raised.

\subsubsection{Internal Challenges}

The financial standing of unions has suffered greatly from membership loss. This is however compounded by failure on the part of unions to realise the full benefit of the low subscriptions that their members make. The procedure for the collection and transfer of union dues from locals to the national unions is fraught with inefficiencies and lack accountability. Some field officers and union leadership have exploited these lapses for personal benefit. All unions reported problems with the structures for dues collection. The worst cases were with the GPRTU that takes direct daily contributions from members at the various loading points. Several cases of indictment of union officers, branch executives have arisen from accusations of financial impropriety. The disbursement of union finances within the various levels for the conduct of union affairs is also problematic and featured prominently on the list of union challenges.

Inadequate union finances have taken a toll on union activities, the most cited being education. Traditional education given elected officers on assumption of duty has ceased in unions like the MDU. During interview sessions union leaders lamented the lack of trade union education and its implication for their work. As some put it 'the days of muscle power are over'; 'we are now in a scientific world and this calls for scientific unionism'. Others pointed out that 'management has several opportunities to upgrade its knowledge and skills and trade unionists must also keep up'. ${ }^{39}$ Leadership quality therefore was a concern for union leaders interviewed. The concern bordered on the ability of the political leadership to understand the policy implications of what union technocrats or staff bring before them. Union structures give leadership considerable control over the direction of policy and its daily implementation. Policy enactment is the responsibility of the Quadrennial Delegates'

\footnotetext{
${ }^{39}$ Interview with MDU field officers, May, 2008
} 
Congress of the GTUC or Quadrennial Delegates' Conference of the national unions (QDCs). However, national leadership, by virtue of its political positioning, controls union policy direction in terms of what it tables before its various QDCs and its commitment to implement Congress or Conference decisions. Policy fall-out is usually a problem of leadership capacity and less one of wilful attempts to sabotage union directives. In most instances, union staff had higher education than their union leaders and greater exposure to union traditions by virtue of its position and length of service. This placed union staff in a situation of wider and more sophisticated insights into the union affairs than the political leaders. This state of affairs was more pronounced for the leadership of the GPRTU where, in some cases, union leaders were not literate in English, the official language of the unions.

Union staff size, quality and conditions of service are some challenges that low finances impose on the unions. Inadequate finances affect the working conditions of trade union staff and limit the ability of unions to recruit the additional staff to carry out union work. The ICU gave instances of losing staff to enterprises whose workers they organise. Financial constraints also affect trade unions' ability to implement renewal strategies. Organising especially in the informal economy involves expenditure that unions are unable to provide and several national unions cite the cost of organising and retaining informal economy workers as a deterrent.

Union leaders point out that internal capacity and cohesion constrain the development of quality leadership for the promotion of workers' rights. Low financial resources affect union ability to marshal resources to build capacity for its technical and political leadership, compromising leadership and membership quality. Trade union education, the key for improving the capacity of leaders and members, suffers from low union finances. Workplace restructuring calls for new ways of doing things altogether, but it takes some measure of technical competency to understand the nature of neo-liberal policies, their underlying principles and implications for workers and their organisations. For the unions, this calls for some organisational culture that demands professionalism in trade unionism, a shift from bare militantism. The development of the required professional standards demands finances that unions have difficulty mobilising.

Trade union leadership capacity goes beyond technical and professional capacity. According to national union leaders it encompasses dedication to the union cause. They therefore made a distinction between union members, technocrats and union activists. Union activists are members committed to the trade union ideals and ready to sacrifice for the development of their unions. They constituted a core cadre that national unions rely on to carry out union work. Low salaries and demands of the economy have made such activists rare. This absence of union activists, they claim, tends to take the political edge out of trade unionism. The political orientation and commitment to defend the interests of union members was a problem of leadership at all levels within the union structures. 
Another challenge outlined was the independence of the support departments that direct union activities and provide input into union policy. The research and finance departments, especially the latter, needs some autonomy from leadership control but at the same time has to be accountable to the unions which they have been set up to serve. Meeting this balance produced some tensions especially when, for reasons of political expediency, elected leaders refused to accept recommendations their technocrats consider vital. Accountability measures were problem areas that few leaders were prepared to venture into. These support departments were also constrained by the usual physical resources for carrying out union work. Low subscriptions were blamed on the lack of resources for the finance department to monitor the inflows of subscriptions. Unions rely on the largesse of their foreign counterparts, especially European and American trade unions and international labour institutions. Their contributions have kept unions alive and helped to sustain union education and capacity building and research. This generosity posed additional challenges in terms of control over trade union agenda and capacity to meet the financial management demands of donors. Union leaders were not clear where the boundaries of their initiatives began and those of foreign support ended.

As unions expand beyond their traditional formal economy, junior staff membership, additional tensions are imposed by the alterations in their internal dynamism. Membership heterogeneity affecting union balance derives from membership rank (senior/junior staff), gender (female/male) as well as economic sectors (for$\mathrm{mal} /$ informal economy). In the first place there is the issue of balancing the needs of various constituents and, secondly, that of redefining union identity to embrace the varied constituencies. The demands of informal economy members on the internal dynamics of unions form the subject for discussion in the next chapter. The tensions produced by pressures on old membership to accept the changing shape of their unions and ceding union space to new members is countered by an equally great pressure generated by new members on unions to make union membership meaningful. Several union leaders found that these tensions raised demands they were striving to contain. Unions that cover a wide range of industrial sectors, like the ICU, also face difficulties balancing the interests of their traditional members. For the GPRTU which is composed of employers, self-employed and employees in the private road sector, heterogeneity in employment status poses a strain on internal cohesion. Union splintering as a result of dissatisfaction with internal democracy is a challenge here that the union faces. Union leaders pointed out several rival unions that have been formed by members dissatisfied with the union. Union fragmentation and splits have been the result of such tensions as union leadership have failed to provide the satisfactory response. In the Ashanti Region, as many as 17 road transport associations were found operating.

Union gender democracy was identified by union leaders as a challenge impacting membership quality. Trade union leaders recognise this as a challenge to union 
representativeness and its claim to be democratic. The nature in which union gender democracy is played out forms the subject for discussion in Chapter Six. What is important to note here is the increasing awareness of union leaders about issues of gender democracy and its impact on union effectiveness and relevance. One measure for improving membership quality has been to bring on board senior staff but the traditional workplace mistrust between junior and senior staff, by virtue of their positioning in the employment hierarchy, is sometimes carried over into union organisational activities.

As unions grapple with meeting membership demands beyond the workplace, one issue that continuously faces them is their capacity to engage in the national policy space. There is the general perception that the policy arena should be occupied by the confederation, that is, the GTUC. However, increasingly, national unions find themselves confronted with national policies within their jurisdiction that requires immediate attention. The general absence of union structures to receive daily working concerns of their members means that unions are constrained when it comes to making immediate interventions on national policies. Policy advocacy, some union leaders believe, should be at the centre of union activity. Unions should build capacity around this and move away from collective bargaining, they insisted. Trade union leaders need to build capacity for campaigning for policy change. This is because national unions have information on policy gaps as a result of the challenges that their members face in the workplace and within their communities. Leaders believe that close contact with membership would have provided a solution to membership dissatisfaction with its unions and promote channels for engaging with daily concerns of workers that can be used as a basis for engaging state policy. The challenge however, is how to evolve an efficient communication medium between union leaders and their members. In situations where membership ability to read is constrained by literacy and lack access to radio and television, unions rely on meetings as foremost form of contact with membership. With irregular meetings and sometimes low attendance, it stands to reason that intra union communication channels will constitute a real constraint.

Union challenges arising out of international and national policy framework impact the workplace to constrain union operations generating further challenges within the unions themselves. Strategies devised by union to counter the challenges should largely emerge for the intersection of membership, workplace concerns and policy. Union leaders lamented the absence of capacity to consistently relate membership concerns with union policy advocacy. There are no structures for the GTUC to tap into the troughs of national unions as a basis for national policy intervention. Union leaders recognise the need to expand the scope of issues they address by making the connection between the workplace and community. The GMWU is particularly concerned about the impact of mining on the national economy and the environment. The immediate victims, the communities, whose livelihood and environment have been destroyed by surfacing mining, remain a concern for the union. How- 
ever, the challenge for GMWU is how to develop links with community initiatives formed to oppose mining companies. As one union leader demanded 'where do trade unions sit in the competing corporate and sovereign interests?' ${ }^{\prime}$

The leadership of GTUC and the national unions displayed an impressive grasp of the nature of challenges confronting them. The origins of these challenges and their impact on unions were sufficiently clear to them as leaders. The leaders understood that union challenges were externally generated within the globalised political economy and take on their own internal dynamics. In highlighting their challenges, leaders were also critical of union internal cohesion and practices. What remains is how this knowledge of challenges feed into the mix of strategies that have been adopted. We turn to examine what union leaders enumerated as constituting the range of strategies that their unions have embarked on to face up to the challenges outlined.

\subsection{DEVISING STRATEGIES}

Examining union strategies requires not only an understanding of the basis of choice but some framework for grouping the myriad of strategies identified in order to derive some means for assessing their relative strengths. Munck distinguishes two approaches for analysing forms of strategies unions adopt for renewal. Munck notes that evolutionary approach stimulated by Michels' iron law served as the dominant framework for studying unions till the late 1980s when unions faced unprecedented challenges (2002). Such models represent unions as evolving from a radical beginning to become more accommodative and less political as they mature. Because this model gives unions no opportunity for revival, they are incapable of capturing how unions lend themselves to change. The other model on the hand, insists that change can only occur within unions on condition that they are class based. The levels of success chalked by unions in reversing decline influenced greatly the development of alternative approaches to studying and categorising emerging union strategies. While some have categorised union strategies by dwelling on the choice processes, others have looked to the targets or content of strategies.

Some comprehensive categorisation of union strategies are outlined by Turner (2004) as well as Kelly and Frege, (2004). Broadly, the strategies delineated are based on how unions use their relations with external actors, like the state or employers or industrial relations institutions, in their attempt to transform the contours of their operations. The resulting six strategies are organising, restructuring or reforming union structures, political action, labour management or social partnerships, coalition building and international solidarity. These can be further compressed into

\footnotetext{
${ }^{40}$ Interview with MDU national leaders November, 2008
} 
three broad groups to cover respectively strategies that seek to secure the cooperation of external actors to advance union strength, to reorganise the external contours of union and to effect internal union restructuring (Turner, 2004; Kelly and Frege, 2004).

Strategies that attempt to influence or secure cooperation with actors or institutions include political action, coalitions with representative groups, political parties or employers. Unions have used such strategies to improve their political clout or mitigate the impact of globalisation on membership decline. Strategies that change union contours aim to enhance union power to directly influence external actors or policy environment. These are achieved by extending union coverage through membership expansion, mergers or affiliations with national or international unions. Affiliations, mergers, and jurisdictional expansion enhance union economic clout, triggering actions for internal restructuring. Internal restructuring helps to improve union efficiency in delivering its functions and facilitating interaction with other actors (Behrens, Hurd, \& Waddington, 2004). Behrens et al however doubt the potential of internal restructuring triggered by alterations to union external shape to drive revitalisation (ibid).

These broad categories of approaches have their limitations as analytical tools for determining how strategies can lead to union renewal. It is in this connection that the attempt by Behrens et al to link strategies to dimensions of union power resources is important (Behrens, Hamann, \& Hurd, 2004a). Utilising the concept dimensions of unions, they outline how union power in four areas- membership growth, economic bargaining, political influence and institutional vitality-support union revitalisation. They contend that union revitalisation is dependent on how strategies lead to an increase in union power in these four domains. The four dimensions proposed by Behrens et al are useful in understanding the effectiveness of union strategies only if the three dimensions of membership, political and economic power are posited as being dependent on the fourth, institutional vitality.

Using the categorisation of Turner as well as Kelly and Frege to group the strategies outlined by union leaders interviewed, three broad groups were identified. The first consisted of attempts to expand union size by recruiting new members and retaining members already under union coverage. The second included a mix of strategies aimed at restructuring the internal organs of the unions. The third and final set was politically oriented strategies, directed at improving union political clout or enhancing union engagement with national policy.

We now turn to examine union strategic choices in Ghana and the implications of these choices for union identity. In the next four chapters selected strategies are examined in more detail in terms of the manner in which they have impacted union power dynamics and what implications the emerging dynamisms hold for a re- 
conceptualisation of union functions and identity to meet the challenges of globalisation.

\subsubsection{Organising: Expanding and retaining membership}

The role of external actors in shaping the form of challenges unions face and availability of resources for addressing their peculiar challenges in the experience of the GTUC and its national unions have been discussed earlier. Standing out of a myriad of challenges was the loss of membership that was affecting union size. It comes as little surprise therefore that membership expansion was high on the mix of strategies unions outlined. All the national unions covered announced activities geared towards recruiting new members to increase membership size and enhance the quality of membership. Increasing membership size involved redefining union jurisdiction in order to widen the scope of potential union members and an intensification of organisational efforts within the traditional terrain. The two-pronged approach, described as extensive and intensive organising respectively, was in response to factors unions have identified as causing membership loss. Intensive recruitment was either within enterprises where unions were already organised as seen in attempts to recruit senior staff or drawing workers from unorganised enterprises located within their traditional domain. Extensive recruitment involved first venturing into the informal economy; second, organising pensioners; and third, getting the youth involved in trade unionism before they join the world of work. While organising gives a boost to union membership power dimension, extensive recruitment enhances union representativeness. Within the formal sector, senior staff and white collar workers were groups of workers that National Unions like ICU, GMWU and HSWU had targeted for intensive membership recruitment. The CBMWU faced with high levels of casualisation in the construction industry had embarked on intensive recruitment by engaging field officers for a fee. The arrangement is to pay field officers $2 \%$ of the dues of the locals they succeed in organising.

Expansion within the traditional terrain is important for National Unions to maintain their right to collective bargaining. Unions had stopped at nothing to retain and expand membership. An interesting approach in this connection was the creation of a company to employ casual union members, a fall out of reforms at Ghana's ports. MDU together with six stevedoring companies formed the GDLC which employs about 3,000 casuals who service the ships that dock at Tema and Takoradi Ports. MDU owns $20 \%$ shares in the company. This has presented a complex situation of conflict of interest for the MDU especially during negotiations.

Union extensive recruitment, as explained earlier, is fraught with problems as it promotes unhealthy inter union rivalry, which had identified as one challenge. An example cited was the almost rancorous jurisdictional struggle between GAWU and TWU which had to be resolved by an external body, the Labour Department. In order to forestall such problems the National Unions are in the process of redefining 
union jurisdiction and re-demarcating union borders. The GTUC had therefore set up a Demarcation Committee to police union expansion through intensive recruitment.

The threat of splits, fragmentation and poaching has compelled unions to devise membership retaining strategies. Retaining members involved activities designed to enhance union relevance through service provisioning. Membership retaining strategies were at varying levels of implementation within the National Unions. In its bid to provide an efficient framework, the GTUC had tasked its Research Department to determine the types of benefits that union members desire beyond collective bargaining and the kinds of schemes National Unions could add to terminal benefits of members. The idea was that increasing the value of trade unions to their members' survival will commit them to remain with their unions. In addition to efforts at the level of Congress, National Unions, like the TWU, GMWU, HSWU, GTPCWU and ICU are also in consultation with their members to determine how they can serve them better. Services unions had outlined to render to their members included activities like:

1. Plans to set up provident fund under the management of an independent financial institution;

2. Providing loan facilities and credit schemes as well as setting up a union managed rural bank to provide credit to rural self employed;

3. On-the-job capacity building for members and provision of sponsorship for further studies;

4. Setting up educational endowment fund for children and wards of members;

5. Community poverty reduction projects as medium for introducing the concept of trade unionism; and

6. Solidarity fund for workers dismissed for carrying out union work.

Planned community projects outlined included the creation of vocational centres and income generating activities as in the case of CBMWU. The TWU had in operation an aforestation project began in 1996 with support from its international affiliate, the BWI. The educational component of the aforestation project covered HIV/AIDS as well as occupational health and safety training. ICU had in place a solidarity fund that provides income for workers who have been dismissed in the course of executing union functions. GPRTU's membership retention activities covered those aimed at securing livelihoods like credit schemes for the purchase or repair of vehicles. Strategies to service members were at varying stages of implementation. Trade unions are aware of the fact that there are already trends in Ghana where workers use consultants to negotiate their conditions of work. Unions, the leaders insisted, have to be innovative to remain relevant to workers, and offering services to members beyond collective bargaining to them provided the answer. 


\subsubsection{Internal Restructuring}

Restructuring union involved expanding the space for members to articulate their concerns and participate in union decision-making. National Unions were engaged in a process of enhancing internal democracy through activities that sought to reduce the gap between leaders and members by revamping their representative structures at the local, branch, district and regional levels. The idea was to secure the National Unions at the grassroots. GAWU, GMWU, ICU, PUWU, and HSWU led in efforts to reduce the gap between leadership and membership. As at October 2007, the national officers of HSWU had completed nationwide regional tour collecting information on the needs of its members. At these meetings, the members subjected their leaders to interrogation and criticism and suggested changes within union structures and operations.

Union strategies also included improving communication between membership and leadership through visits by national leaders to the locals and branches. GMWU announced plans to make the General Secretary part of branch executive meetings to improve leadership/rank-and-file contact. ICU had instituted more in-house seminars for union staff to appreciate union strategies, improve staff morale and commitment to the union. GAWU led in efforts to make space for informal economy members in union decision-making. Improving membership and leadership contact depended on improving internal communication, a challenge that unions had planned to address through the use of ICT, internet, websites, radio programmes, newsletters and quarterly publications. The GTUC was also seeking some direct interaction with its affiliates beyond the Executive Board. National Unions were required to submit reports to the Secretary-General. In addition the SecretaryGeneral had been granted responsibility to participate in the meetings of the NECs of the National Unions.

The gender profile of unions was also an issue for the GTUC and its affiliates. Efforts had been geared towards improving female participation and representation in trade union activities through the establishment of a Gender Desk and Women's Committees in the GTUC and National Unions. Chapter Six gives a detailed explanation of trade union restructuring to enhance gender democracy and how these efforts connect with the concerns of the female union members.

There was recognition that restructuring placed demands on union capacity and required office holders to remain informed. Union leaders explained that the challenges of the growing demands of work for political leadership of unions at all levels of union structures make them dependent on specialised union staff. Again the challenges of meeting varying needs of the increasingly diverse constituencies of union members demanded technical capacity from unions. The plan was to identify the capacity requirements for the effective functioning of union leaders. The GTUC and National Unions have sought to build the capacity of union staff through what the Head of Organisation describes as the 'professional way'. The specialised de- 
partments of the GTUC charged to lead union capacity building were the Organisation, Education as well as the Research and Policy Departments. National Unions like the GAWU, ICU, GMWU, HSWU, and PUWU for example have worked out systems for restructuring union rules to allow elected officers and union staff to build and renew their capacity to gain a better understanding of globalisation and manage trade unions. Union capacity building called for union specific educational programmes and sponsoring cadres to pursue learning in tertiary institutions. Trade union education is provided for leaders, union staff and members at national, regional district and local levels that orients them to union challenges. The collaboration with the University of Cape Coast has resulted in university-based courses in labour studies from certificate to post graduate certificate. It has been possible through this arrangement for trade unionists without the traditional requirements for entry into university to gain access to undergraduate and graduate programmes. Radio programmes were also used to alert workers about their labour rights. Unions are beginning to apply, albeit slowly, professional principles in staff recruitment to take care of the demands of members and the refinement in workplace management. The GTUC had taken to devising policies, as well as medium term and strategic plans to guide union work over specified periods.

Enhancing union capacity had also called for strategies to improve union finances. This has been done through setting up income generation projects in the form of hostels to reduce union reliance on dwindling dues. ICU, HSWU and PSWU led in this effort. Hostels served the additional advantage of reducing union expenditure on venue for its programmes and providing members affordable accommodation during travel. Other fund-raising efforts consisted in drawing up proposals to raise funds to support union activities (GAWU). This strategy clearly sees union dependence on donor funding as viable solution to union financial problems.

One strategy for improving internal vitality covered activities directed at restructuring National Unions and changing the confines of their jurisdiction. Plans to get National Unions to merge along economic and industrial sectors constituted one such strategy under discussion during fieldwork. Public sector unions like TEWU, PSWU, PUWU and HSWU are being urged to merge. Government's plans to introduce the single spine salary structure have compelled the adoption of a common negotiating platform by public sector based national unions. This had called for greater collaboration and common actions. Transport based unions, the REU and RWU on one hand and the MDU and NUS on the other, were also talking about mergers. In addition, there were suggestions that the TWU and GAWU-which had just emerged out of a bitter jurisdiction dispute-should begin merger talks. The notion was that any ambiguity in jurisdiction between unions that lead to a struggle over members suggests that they belong together and should merge ${ }^{41}$. ICU was also

\footnotetext{
${ }^{41}$ Interview with head of Policy and Research Department, December, 2007
} 
contemplating merger talks with GAWU, GMWU. But the National Unions contend that mergers, even though strategically sound, have practical problems, least of which was the size of unions planning to merge and the personal interests of leaders fearful of losing their power bases in the unions. Mergers remained ideas and very little has been done to set the process in motion.

\subsubsection{Political Action}

Union political power, according to Behrens et al (2004), depends on its ability to impact the political setting of a nation in the three areas of election outcomes, the development and enactment of legislation and its implementation. Policy making however underlies political actions of all governments and underscores legislations that evolve to circumscribe the environment within which labour operates. Elections are normally swayed by the ideology guiding the policy directions of political parties but they are one off events whereas policy making is an ongoing process. Recognising the impact of public policy on livelihoods in Ghana, the GTUC pays attention to the public policy domain particularly the budget. It began an annual process of commenting on the budget after it has been presented to parliament. Over time its critique has been seen as an important input and now the GOG circulates draft budget for GTUC inputs before it is finalised for presentation to parliament.42

Other efforts to strengthen union political action have come in the form of coalitions with other labour movements and civil society groups like NGOs and CBOs. The GTUC and the National Unions, through coalitions with NGOs, mobilised protests against policies perceived to be inimical to national interest because they threatened livelihoods in Ghana. Good examples were the European Union sponsored Economic Partnership Agreements (EPA) and the Procurement Act, the sale of the Agricultural Development Bank and water privatisation. Collaboration for political muscle to protest negative policies have also demanded that unions consider employers as possible collaborators. The CBMWU was seeking the support of the various Ghanaian contractors' associations to back its demands on GOG to reserve some percentage of jobs for Ghanaians under the Procurement Act in order to counter the negative impact of Chinese construction enterprises on the labour market. The CBMWU had in place an agreement with the Association of Ghanaian Contractors and other companies executing contracts in Ghana for minimum wage levels for construction workers and severance awards to be paid at the end of a construction contract that covers all workers. Chinese contractors remain outside the fold of this employer group.

National Unions were also seeking to form partnerships with other sector based associations. NUS for example, was exploring the possibilities of forming an alliance with senior staff organ in the shipping industry, Ghana Merchant and Navy Offi-

\footnotetext{
${ }^{42}$ Interview with Secretary-General, December, 2007
} 
cers' Association. The last type of collaboration which borders on labourmanagement partnership involved public sector based National Unions like the HSWU, PSWU and PUWU working at improving their service delivery or productivity to ensure enterprise survival and viability and improved public image. There were also efforts to build sub-regional solidarity. One such initiative mentioned was that between GTUC and the NLC. The CBMWU had exchange programmes with its Nigerian counterpart for protecting construction workers in both countries. A recent exchange programme between the two unions agreed that both unions should provide protection to each others' members and work out modalities to ensure that earning levels were the same in both countries. GAWU also has similar collaborative schemes with its Nigerian counterpart and which had also led to joint programmes in both countries.

Renewal strategies of the GTUC and its affiliate national unions appear to concentrate on union membership expansion, internal restructuring and political action. National unions had different levels of renewal enthusiasm. But all unions had in place some strategy of retaining members and expanding union size. It appears that union political muscle is seen as most important leading to a concentration on membership satisfaction and size expanding. The indications are that union strategies are effective only to the extent that they are built on a sound union structure and form or lead to strengthening unions. By concentrating on organising, internal restructuring and political action, unions appear to be relying more on their internal power as workers and less on partnerships to expand their influence. The fact that the majority of strategies are directed at expanding, maintaining and enhancing their membership shows how much stress unions place on the membership power dimension. Coalitions have also moved in the direction of building alliances with other worker based groups or community organisations and NGOs. There has been little stress on building political alliances with political parties. This strategic option is a no go area for the GTUC and its national affiliates because of their peculiar history. Policy engagement means levels of engagement with the state outside formalised corporatism that allows the GTUC to retain its autonomy and steer away from cooption. The GTUC and its national affiliates appear to believe in workers' might and work to partner more with labour movements, a suggestion that they look to build power through a broadening of workers' front as an organised movement.

While these strategies point to strengthening unions in all areas of union power dimension as outlined by Behrens et al, their limitations will lie in how they have been conceptualised and ability to expand union goals and functions beyond the workplace. The dominant direction of GTUC strategies on building membership power brings up questions of emerging changes in union space and how it is used by different categories of union members for pursuing their needs. An essential consideration in union revitalisation should be how the internal structures respond to the changing dynamics in union membership structure and how this in turn shapes union functions. 


\subsection{SUMMARY AND CONCLUSION}

The main sources of union challenges were the global level organisations and institutions that evolved the neo-liberal policies that shaped the national policy landscape, in the specific instance of Ghana, the IMF, World Bank and WTO. Other regional bodies included the European Union that sets the pace for African Union collective decisions and actions as well as the ECOWAS. Lately the controversial Economic Partnership Agreements of the European Union point to the connection between state policy making apparatus and sub regional control. These translate into national policies like privatisation, Procurement Act, trade liberalisation, subsidy withdrawal and liberal labour legislation which curtail union power challenging union ability to function effectively in the defence of its members.

Policy challenges affect union size through loss of members, undermines union role in policy making and right to utilise political and social partnerships to secure their gains. Unions are unable to defend their members because they lack legitimacy as they are no longer representative of the working force of the countries in which they operate. In the specific case of the GTUC, its coverage of 350,000 workers out of a total workforce of 8.2 million raises serious doubt about its legitimacy as the true representative of Ghanaian workers. The limitations in representativeness also raise concerns about keeping union agenda consistent with real concerns of the working people of Ghana.

The ability of the GTUC and its affiliate national unions to fashion alternative means for remaining relevant to their membership is dependent on how workers' workplace concerns are connected to the general global economic framework. This concern appears to give credence to Kelly and Frege's assertion of trade unions as strong organised actors that can promote alternative viewpoints for turning policy round (2004). Perhaps the domination of neo-liberal principles within the policy space has been the absence of competing policies. There is no end in sight for workers freedoms. Corporations and industries buckle under the financial crisis and the preferred solutions are those that diminish the little space that workers hold in the workplace. As trade unions turn their attention to dealing with direct challenges of globalisation they become reactive responding to the direct effect of globalisation on workers leaving, the underlying principles and its operational framework intact. The need for unions to devise an alternative development agenda however has become imperative as the global economy takes a down turn.

The mix of strategies adopted by the GTUC and its national unions, in order of importance, included expanding and retaining membership by restructuring union shape, structures and processes in addition to enhancing union capacity to deliver its core responsibilities. Strategies targeting external factors included intensified policy engagement at the national level and coalition building with a range of actors. These strategies have been in response to the impact of globalisation on the 
shape of work in the sectors that the national unions organise. Changes in plantation agriculture, marking shifts to the use of out-growers had forced GAWU for example, to concentrate on the rural self-employed in very serious ways. The MDU had to resort to union owned enterprises to keep its members because of the direction of port reforms. Sector specific reforms arising out of globalisation therefore becomes an important factor for the final content of membership maintenance and expansion strategies.

The GTUC and the national unions appear to be focused on building membership and institutional power dimension for union revitalisation. With regard to coalitions and political action, the stress was on using workers political power and here the GTUC is in a leadership position seeking to broaden the front of organised labour in Ghana. Membership power forms the bedrock on which union political clout and economic power is built and the strategies appear to recognise this fact. The limitation however is how the stress on building membership and institutional power dimension allows the GTUC and its national unions to enlarge union function beyond the workplace and take on board the varying concerns that an expanded membership brings into union struggle terrain. Lambert insists that how unions define their role in the present political economic system and the extent to which strategies allow unions to build an alternative power base beyond the narrow confines of the workplace and the nation state, lead to better union revitalisation (Lambert, 2002). This is a position reiterated earlier by Fairbrother when he states that attempts at redefining union role and purpose can set the parameters of union concerns within the contradictory experiences of workers in the workplace and community (1990). This redefinition is however dependent on how unions respond to changes imposed by the various revitalisation strategies on union structures and the ability to make the necessary connections between the numerous concerns that various members bring to the unions and the national and international political economy. In all these strategies, serious engagement of unions with workers concerns beyond the workplace was low. In terms of identifying challenges, the role of national and international policy framework on the workplace was clear for unions. Their choice of strategies however, gave little indication of any possibility of forcing a debate on development alternatives in Ghana at this crucial moment of economic down turn. Strategy choices suggest some understanding of power play among union members in the determination of space for the pursuit of work place concerns. What is the nature of this power dynamics that emerge in the various strategies that seek to enhance union membership? This question informs the examination of union engagement with informal economy where the majority of the working people of Ghana are located. 



\section{Chapter 5}

UNIONS IN THE INFORMAL ECONOMY 


\title{
5 UNIONS IN THE INFORMAL ECONOMY
}

\begin{abstract}
Trade unions' organisational work in the Ghanaian informal economy has a long history dating to the origins of organised labour under colonial rule. This long history notwithstanding organising informal workers still remains daunting for unions. GTUC's and its national affiliates' successes in the informal economy have been varied and effective coverage continues to grapple with how to incorporate informal economy members into union structures. This chapter examines the approaches unions have utilised for organising the informal economy workforce and the nature of union structures utilised to support its representation. It also examines representational issues arising out of the manner in which informal economy members are integrated into union structures and the problems of internal democracy arising out of the channels offered informal economy workers for representation and voice in union decision-making. It notes how organising informal economy workers served as a union strategy for reversing decline and a re-conceptualisation of union function. Organisation in the informal economy however, has not translated into union ability to link informalisation of the formal with informal work. As a result unions are yet to realise the opportunities organising informal economy workers could provide for addressing union revitalisation within the political and membership dimension and eventually impact their economic power.
\end{abstract}

\section{$5.1 \quad$ INTRODUCTION}

The increased informalisation of labour and production forms presents both challenges and prospects for organised labour (Munck, 2002). Shrinking formal economy work and expanding informal employment means that trade union claim to representing working people is being seriously contested. Closing what Webster calls 'the representation gap' demands that trade unions develop capacity to articulate the concerns of their informal economy members and devise strategies to pursue these concerns. However, the unique features of informal work constitute barriers to trade union organisational efforts (Webster, 2005).

Barriers to trade union organisation of informal economy workers include the extreme heterogeneity of the workforce as outlined earlier, and the corresponding multifarious forms of labour relations that arise. Informal economy workers are less bound by the known traditions of formal employment and their concerns far removed from issues of collective bargaining (Philip, 2005). 'Their immediate con- 
cerns are related to threat of eviction ..., and access to inputs for their productive activities in the form of credit, and market access for their products'. Informal economy workers can be 'individualistic or communalistic in orientation' depending on the nature of their production activity (Munck, 2002, p. 117). Informal economy labour relations do not follow traditional work relations within the capitalist production relations. Workers are not in the traditional relations with an identifiable owner of capital. This results in an absence of an identifiable negotiating partner or counterpart (Webster, 2005). Daily struggle to earn a living is waged more within sites of contestation with government policy and the traditional exploitative social norms and practices (Philip, 2005). Relations with capitalist exploitative systems appear remote, but all are agreed that final beneficiary is capital even in its globalised form (Alenjandro, 2002).

The opportunities that informal economy workers bring to trade unions include strengthening union legitimacy and giving better grounding for trade union revitalisation (Webster, 2005). Realising such opportunities however rests on the ability of unions to make the crucial link between the workplace, domestic economy, community concerns and national economic policies (Munck, 2002 (Webster, 2005). Some recommendations to unions for realising the benefits of informal economy organisation are through a re-conceptualisation of trade unionism as social movement unionism or the broadening of union constituency and forming alliances with groups outside the traditional formal economy fold of unions (Webster, 2005; Munck, 2002; Von Holdt \& Webster, 2005). Social movement unionism, Munck explains, operates on two assumptions: one, that workers have multiple identities and second, that labour politics extends beyond the workplace (Munck, 2002, p. 149). These recommendations for union engagement with informal economy workers have implications for union structure and form. The working conditions and the nature of informal employment incorporate forms of production relations that stand far removed from formal employment that underlies the conceptualisation of trade union form and structure.

The traditional focus on trade unions and informal economy workers has been to identify organisational difficulties either within the informal economy workers or in the nature of their work that inhibit unionisation, which Webster captures as the axes of bargaining discord (2005). Webster's framework for identifying factors constraining and promoting organisation is useful for unions which are considering the task of informal economy organisation. For the GTUC and its national unions who have overcome the barriers of informal economy organisation, the main challenge has been how to maintain their membership in union structures once organised. Informal economy workers have also shown an intense interest in union affiliation. However their membership has produced tensions on union structures. Granting union meaningful union membership has been a serious challenge to trade unions. This is an area seldom investigated and little is understood about the tensions that informal economy membership imposes on traditional trade union structures. This 
chapter examines the challenges of union internal democracy faced and the experiences gained. The chapter explores the experiences of all the 17 union affiliates of the GTUC as well as the ICU. Information was first gathered from national officers about union work in the informal economy. Where they existed, informal economy desk officers of the national unions were also interviewed. Once identified, the leaders of informal economy groups organised by the national unions were then interviewed in groups ${ }^{43}$. The interview data was supplemented with information from union documents on the informal economy as well as existing research reports. The interviews were conducted mainly in the Greater Accra, Eastern and Central Regions. These locations were determined by the operating terrains of the informal economy groups organised by the unions. The findings were later shared with representatives of informal economy groups, trade union leaders and informal economy desk officers in January, 2008. The chapter begins by exploring the conceptual issues underlying the definition of the informal economy and its linkages with the formal and how such issues affect national and union policy choices.

\subsection{THE FORMAL AND INFORMAL IN NATIONAL ECONOMIES}

The conceptual identification of the informal economy is usually attributed to two seminal studies in the early 1970s. These are Keith Hart's anthropological study of urban employment in Accra (Young, 1993) and ILO's economic assessment of urban employment in Kenya (Todaro, 1994). These studies were significant in terms of the official recognition they gave to the sector's contribution to national economy and the deplorable conditions under which informal workers operated. They also exposed the enormity of labour market problems confronting developing countries such as Ghana. The most important contribution however is the academic and policy visibility they gave to the informal economy and its workers.

Studies and reports on the informal economy devote considerable space to the definition of the informal and emerge still less clear than the very lack of clarity in existing efforts they had sought to address (Williams C. C., 2008; Aksikas, 2007; Reddy, 2007; Cooke, 2006; Dasgupta, 2003; Overton, 2000; Ninsin, 1991; Peattie, 1987). The differences have their origins in what is perceived as the linkages between the formal and informal, the representation of hierarchical duality and the range of activities that are designated as informal. The multiplicity of definitions also diverges in their assumptions about the structure and operation of the national economy being explored. Most definitions assume an undisputed identification of the formal and present the informal as lacking clarity and in need of definition. The formal therefore serves consistently as the definitional reference point for the informal (Lyons \& Snoxell, 2005; Hormeku, 1998; Bryceson, 1995; Matsebula, 1996; Ninsin, 1991; Peattie, 1987). Reddy attributes the fixation on the formal as the standard to 'dualist'

\footnotetext{
${ }^{43}$ See Appendix for list of union leaders interviewed
} 
theories of development which 'postulated that developing economies comprised ... traditional and... modern sector[s]' (Reddy, 2007, p. 463). This dualism does not suffice to explain the tendency for contesting definitions to use the formal as reference because even writers critical of dualism proceed from the formal in their search for an understanding of the informal in national economies. Perhaps Williams' conclusion that centrality and validity of the formal in contemporary Western society accounts for 'how all work that is left over is cast into this residual catchall umbrella category' of informality, provides a better answer (Williams, 2008, p. 107).

Dualistic tendencies underlying the definition of the informal economy diverge within two strands of approaches; those that locate it as a distinct and separate site of economic activity and those that position it at one end of a continuum in relation to the formal. The continuum approach proposes national economies as a range of economic activities occurring on a scale of increasing or decreasing formality. Separate site definitions conceive of national economies as two distinct sites; the energetic one propelling to prosperity and the old backward refusing to accept change. The informal is set as a separate sector of economic activity and its workers a distinct socio-economic group (Reddy, 2007; Williams \& Round, 2007). Within the dualistic frame, definitions have tended to provide lists of characteristic features of the informal economy either in relation to its link with the formal economy, the features of its labour force, enterprise size, employment status, the modes of resource utilisation or levels of production technologies (Todaro, 1994; Young, 1993).

Dualist definitions often identify the formal by features in opposition to normative standards of the formal (Overton, 2000). The distinguishing features of informality usually set in negation of the formal represent the informal as engaged in spaces or activities beyond the confines of legality, with little adherence to regulation (Ligthelm, 2005). This position characterised the original definitions of Hart and the ILO. Subsequent ones, like Matsebula (1996) Dasgupta (2003) and Aksikas (2007), define the informal by presenting lists of features that contrast the informal with the formal. The usual objection to such definitions is the hierarchical ordering of the relationship between the formal and informal. In this ordering, the informal assumes a subordinate or inferior status and blamed for crowding out the space required for generating the developmental force for energising economic growth in developing countries such as Ghana (Williams C. C., 2008; Reddy, 2007; Williams \& Round, 2007). Such definitions served to cast the informal economy in negative light directing policy energies towards formalisation strategies. With the advent of economic liberalisation, as formal sector practices utilised informality to shed labour costs, and state withdrawal from welfare provisioning took its toll on poor citizens, the formal lost its standard bearing position (Williams \& Round, 2007; Overton, 2000). This is the position of the World Bank as it urged governments of developing countries such as Ghana to utilise the employment and entrepreneurial potential of 
the informal economy to resolve problems of employment generation. Williams' critical review of the competing representation of the relations between the informal and formal economies explains how in this instance the informal is represented as the more dynamic centre offering solutions to the beleaguered economies of developing countries (2008).

Criticisms of dualistic definitions of the informal economy have been directed at two issues, the erroneous importance accorded the formal and secondly the tendency for superficial analysis which dodge more fundamental issues of production relations and the place and function of the informal in national economy (Smith \& Stenning, 2006; Overton, 2000; Hormeku, 1998; Ninsin, 1991). By focusing on the external characteristics of the informal economy production activities, the ensuing policy prescriptions tend to be flawed as a result of the exaggerated importance assigned the formal (ibid). Such writers recommend situating the definitional base of the informal economy at the level of production relations within enterprises and the broader economic landscape of national economies.

The definitions highlighting formal and informal economy relations set out to correct the seemingly erroneous perception that national economies are composed of distinct discrete entities. They still however, utilise the formal as the norm. Davies (2004), Beneria (2001), Overton (2000), Ninsin (1991), and Homeku (1998), maintain that the formal and informal are better regarded as two extreme sites on a chain of production activities operating within the same economic framework. The informal economy, the exploited and indispensable product of the formal peripheral capitalist economy, reflects the failure of capitalism to penetrate the economies of developing countries (Aksikas, 2007; Homeku, 1998; Ninsin, 1993). The informal and formal economies are in asymmetrical relations with the informal serving in a subordinate and dependent capacity. The informal however remains functional to the survival of the formal because it has the ability to subsidise the reproduction of the formal and absorb its shed labour force. This relationship accounts for the existence of formality within the informal or the recourse on the part of highly formalised enterprises to informal employment. The dependent and marginal view does not see the informal sector as dynamic or offering a solution to the problems of African economies.

Both debates agree however that the informal attracts attention because it is unlike the formal in ways that produce problems for the interests of its labour force. The scale or continuum approaches have been more concerned with employment standards and levels of poverty within which workers operate. The strong point of the dependent approach is its ability to take on board the diverse nature of work cast out by the formal into the informal. It also allows an interrogation of national economies and factors generating informality and the relations of power between the informal and formal economy. 
Most writings on the informal economy, as part of the exercise in offering a definition or evolving suggestions for improving conditions of work in the informal interrogate the informal/formal link (Reddy 2007; Davies, 2004; Overton, 2000; Beneria 2001; Hormeku, 1998 and Ninsin, 1991). Debating the informal/formal linkage appears to be an exercise that is difficult to dodge considering that informal is deductively defined drawing meaning, understanding and recognition from the formal. The importance of pursuing linkages is usually driven by an urge to offer solutions for development related problems like the employment opportunities and improvement in employment conditions. The emerging conceptualisation of formal/informal linkages forms the basis for evolving policies for dealing with employment problems of the informal economy.

Williams (2008), Aksikas (2007) and Matsebula (1996) have devoted some space to exploring trends in linkages presented in works on the informal economy. Their works reveal that the linkage debate derives largely from issues underlying the definition of the informal economy discussed earlier. Mastebula (1996) states that the formal/informal linkages are represented in literature variously as autonomous, complementary or exploitative. Williams (2008) in a later work however, distils the linkages outlined as presenting the informal economy as being a residual, byproduct, complementary or alternative to the formal economy. Aksikas for his part limits the categorisation to two: temporal, residual and accidental on one hand or interdependent on the other (2007).

A close examination of Williams and Mastebula's groupings reveal similarities in terms of the positioning of the informal economy in national economies and its relations to the capitalist mode of production. Firstly, groupings either characterise the informal and formal as having separate existence or being interrelated or intertwined. The informal in its separate existence is either a residue, unregulated, autonomous or an alternative mode of economic activities (Mastebula 1996; Williams 2008). Where the informal and formal are presented as integral parts of one economy they are either in an interdependent position or intertwined in an asymmetrical relationship with the informal in a marginal position. The formulations that characterise the formal/informal separate existence can either situate the formal as the emerging form or the informal as set to replace the formal. Williams gives the caption 'residue'. Aksikas (2007) isolates relations in this order that assigns the informal as temporary or an 'accidental phenomenon' that 'will disappear with... time...when the formalised sector...absorb[s] or integrate[s] [it] into its sphere of dominance' (2007). The informal is characterised variously as primitive, traditional, weak, backward or pre-modern or as illegal and lacking regulation. Illegality has been defined severally to either include criminal activities as in smuggling, or to cover activities that lack regulation i.e. legal but unlicensed (Williams \& Round, 2007; Ligthelm, 2005; Smith \& Stenning, 2006). The formal, the superior, is presented 
as the resilient, ubiquitous, progressive and expanding sector driving the national economy and responsible for generating economic growth. The policy bend arising out of this characterisation is formalisation of the informal through regulation, registration, documentation and taxation. Two formalising policy approaches adopted include the provision of incentives like credit access and entrepreneurial training or punitive measures directed at intensifying ability to detect unregulated enterprises with high levels of penalties for offenders (Williams C. C., 2005). Even though discussions on the informal economy has largely abandoned the residual accidental positioning, this approach still informs policy in several spaces and somehow underlies renderings of how the formal/informal related.

The criticism of the characterisation of informal as a residual economy has resulted in several alternative renditions. Criticisms have been directed at the assumption of a single trajectory for development, its tendency to reduce economies into binary modes, and a prediction of its eventual demise. Critics have bemoaned the bent to assign a single path to development utilising the historical experience of the western industrialised nations as the norm. Williams, quoting Carrier, captures this as 'virtualism...driven by ideas and idealism the desire to make the world conform' to the idea once created (Williams C. C., 2008, p. 109). The fact that in many countries it is the informal economy that is expanding and engaging the majority of income earners is disregarded (Munck, 2002) and also ignored is the existing 'structural or dialectical interconnections' between the two spheres (Aksikas, 2007, p. 251). Several writers have found the separation of the informal and formal economy problematic and insist that the two are interrelated in a number of ways, most important of which is the fact that workers tend to straddle the two sectors and consumers derive their needs from both (Munck, 2002; Ninsin, 1991).

The second categorisation, the by-product, interdependent or exploitative relationship, has its origins in the Marxist and dependency theories (Alenjandro, 2002; Munck, 2002; Overton, 2000; Hyman R. , 1999; Hormeku, 1998; Ninsin, 1991). The informal and formal are set as integral parts of national economies and not separate entities. Aksikas' explanation is that informal economy is the 'natural and symptomatic by-product of the inherently exclusionary and marginalizing nature of the capitalist economic structures and practices' (2007: p. 250). Informality is a product of late capitalism representing its failure to meet production and consumption needs of the world's marginal populations, be they in developing, developed or transition countries (Aksikas, 2007; Munck, 2002; Overton, 2000; Hyman R. , 1999; Ninsin, 1991). The capitalist mode of production transported under globalisation into Africa reinforced and redrafted existing pre-capitalist forms of production relations (Alenjandro, 2002; p. 206). 
Informal economic activities under the exploitative characterisation are survival activities that subsidise capitalist production either directly through cost reduction strategies of formal enterprises by sub-contracting, atypical flexible work (casual, contract), or indirectly as in supply chain relations where export crops are grown by peasant farmers for export. The formal in its position of strength characterised as the exploitative, parasitic and growing part of the national economy is able to feed on the informal to increase its competitiveness. The informal is the survivalist, dependent, cost reduction, degrading sector, sometimes bordering on underemployment. The informal economy has no potential for growth and does not contain any solutions to the unemployment problems of developing economies such as Ghana (Aksikas, 2007).

There are few variations in this form of characterisation in terms of the nature of relations and policy options. While some position the informal within a continuum moving from decreasing formality to increasing informalisation, others present a shading of economic activities where workers and enterprises utilise informality for survival or to increase profitability. In this sense Mastebula (1996) contends that two types of informal operations are yielded: these are firstly those that are directly linked to the formal as in subcontracting and causal work and secondly those that are indirectly or distantly related, as in urban informal survival economic activities that predominate in African countries. The emerging policy prescriptions point to either facilitating the entry of informal economy workers into the formal economy or a complete eradication of capitalist mode of production responsible for creating informal forms of production to serve its accumulation interests. This position has been criticised for serving political ends or being unrepresentative of the entire range of informal economic practices (Samers, 2005). Williams insists that not all informal economic enterprises are survivalist and that some forms have the potential to serve and have actually served, as the cradle for entrepreneurship, nurturing the beginnings of highly successful formal sector enterprises. The fact that a few are able to escape the informal survivalism does not cater for the exploitative conditions of the vast majority of informal economy workers.

The third categorising which posit the informal economy as complementary to the formal, identified as the reinforcement thesis according to Williams was set to negate the marginality or by-product thesis (2008). The formal and informal economies are projected as being in an intimate mutually reinforcing plural existence. Growth in one sector is transmitted positively to the other; similarly the two sectors decline concurrently (Williams 2008). Informal production activities are largely noncapitalist and do have the potential to generate economic growth, neither is the formal market for profit forms of production activities exploitative of the informal. The formal and informal exist in several modes of relations either as diverse or multi-activity economies especially of transition countries of Europe or in more 
developed economies of the West where the informal provides a source of welfare protection for citizens outside state support systems (Williams C. C., 2008; Overton, 2000). The strength of the informal is its ability to provide options for those who have no access to formal structures and processes. The ensuing policy options are to harness the informal to complement formal employment opportunities or welfare systems. The criticism of this approach has been its tendency to celebrate survival techniques as options that can replace welfare systems as the state relinquishes its social responsibility towards its citizens (Overton, 2000).

The last characterisation has its origins in the alternative development discourses that set development as a process towards informalisation. The informal is presented as modern and progression towards change, a site of resistance for evolving alternatives to the inefficient and environmentally damaging formal economy activities. The alternative or autonomous relations, predict a gradual demise of the formal as informal non-capitalist forms for production gain root. The informal is assigned positive features while the formal in this instance takes on negative attributes like, over protected, rigid, un-dynamic, non-innovative and destined to extinction. The variants are the neo-liberals who complain of overprotection of product markets by the state and the inflexible labour markets dominated by trade unions. For environmentally concerned Greens, the informal, presented as localisation and self-reliance, serves to counter the threat of globalisation to the environment. The emerging policy options are to liberate the labour markets from trade union intervention and get state support for informal economic activities not harassment. Smith and Stenning criticise this position for its inherent risk of failing to expose forms of exploitation and inequality that exist in informal economy production relations (Smith \& Stenning, 2006).

The frameworks for explaining links have sought to examine the comparative positions of the formal/informal in relation to their relative importance in national economies or place them within the development of the capitalist mode of production. These two modes are captured in the two tables below (Tables 5.1a and 5.1b). When the linkages are placed within national economies the informal and formal constitute separate entities with no linkages. The ensuing binary hierarchies that are identified as characterising their relations derive from the formal as the standard which makes the informal negative. The informal retains positive features when it assumes the standard bearing position within the alternative and autonomous relations. In these forms, the two are set up as opposites with the superior carrying the energy that will propel national economies to progress. The informal and formal are positioned in a diverse relationship as is the case of multiple economies of transition countries of Eastern Europe. Here the two are in a mutually reinforcing relationship and are complementary to each other (Table 5.1a). Where they are intertwined, the national economy is a unitary whole in an interdependent or exploitative relationship not fragmented. 
Table 5.1a Characterisation Based on Formal Informal in National Economy

\begin{tabular}{|l|l|l|l|}
\hline Positioning & Representations & Forms \\
\hline $\begin{array}{l}\text { Separate } \\
\text { [no connections clear- } \\
\text { cut distinctions] }\end{array}$ & Binary oppositional hierarchies & $\begin{array}{l}\text { Negative } \\
{[\text { Formal as Standard] }}\end{array}$ & $\begin{array}{l}\text { Residual } \\
\text { Marginal } \\
\text { Temporal } \\
\text { Accidental }\end{array}$ \\
\hline $\begin{array}{l}\text { Diversity } \\
\text { [Multiple economies] }\end{array}$ & Mutually reinforcing & $\begin{array}{l}\text { Positive } \\
\text { [nformal as standard] }\end{array}$ & $\begin{array}{l}\text { Alternative } \\
\text { Autonomous }\end{array}$ \\
\hline $\begin{array}{l}\text { Intertwined } \\
\text { [Unitary] }\end{array}$ & Exploitative asymmetries & $\begin{array}{l}\text { Complement } \\
\text { Complementary }\end{array}$ & \\
\hline
\end{tabular}

When the relations between the formal and informal are set within capitalist modes of production four positions are discerned. The informal is either a pre-capitalist form of production and doomed to extinction as national economies modernise and become more formalised (Table 5.1b). Others present the informal economy as a product of late capitalism that allows more exploitative forms of labour relations as capitalism devises means of getting hitherto non-market forms of production relations to add to the surplus value it appropriates. Where the informal economy is characterised as being in a complementary relationship with the formal then economic activities are characterised as non-capitalist. National economies are diverse or composed of a multiplicity of economic modes of production systems. For writers who position the informal economy as an alternative to the formal, the informal is a post-capitalist form of production system and points to the future of work structures and production systems.

Table 5.1b Characterisation Based on Formal Informal and Capitalist Modes of Production

\begin{tabular}{|l|l|l|}
\hline Positioning & Representations & Forms \\
\hline Pre-capitalist & Backward/traditional & $\begin{array}{l}\text { Residue } \\
\text { Temporal } \\
\text { Marginal } \\
\text { Accidental }\end{array}$ \\
\hline Late capitalism & Exploitative/subsidising & $\begin{array}{l}\text { By product } \\
\text { Exploitative } \\
\text { Interdependent }\end{array}$ \\
\hline Non-capitalist & Plurality/diversity/multiplicity & $\begin{array}{l}\text { Complementary } \\
\text { Plural economies } \\
\text { Autonomous }\end{array}$ \\
\hline Post-capitalism & Resistance/challenging & Alternative \\
\hline
\end{tabular}

The import of the range of categorisations of informal/formal economy relations for trade unions is how they inform approaches to the organisation of informal econ- 
omy workers and the emerging nature of a mobilisation platform adopted for addressing their livelihood interests. The categorisations that set the informal economy as a by-product, reveals the exact relations between the informal and global capital mode of production. This categorisation permits deeper interrogation of inter and intra sector production modes and relations which provide the basis for unravelling the derivation of benefits from the productive efforts of informal economy workers. Clarity about production relations between and within sectors, as well as the whole system through which benefits accrue and are distributed is important for unions as they struggle to devise strategies for organising and representing informal economy workers. The next section takes a look at the factors accounting for the expansion of the informal economy and the implications for organising and representing informal economy workers.

\subsection{INFORMAL ECONOMY GROWTH FACTORS}

Informal economic activities have seen an unprecedented growth under globalisation (Aksikas, 2007; Reddy 2007; Cooke, 2006; Lyons and Snoxell 2005; Munck 2002; Overton 2000; Hyman 1999). Two related factors accounting for growth are the contraction of the formal economy and recourse to survivalist strategies by the populations neglected by their nation states. Cooke for example explains that expansion of informal employment in formal settings is a 'response to the increasing level of globalizing competition in the private sector, growing pressure for the state sector to contain cost and enhance performance' (2006). Other factors identified are rapid urbanisation, income pressures for low-income earners, the demand for low cost goods and services as well as lack of employment opportunities for the majority of people in developing countries (Reddy, 2007; Smith \& Stenning, 2006; Lyons \& Snoxell, 2005; Overton, 2000).

The informalisation of the formal economy, variously captured as informalisation from above, or capital restructuring, is largely motivated by cost cutting measures to make companies competitive or reduce government expenditure (Von Holdt \& Webster, 2005). Public and private companies cut costs through different modes of causualisation where workers retain some relations with the core employer but are pushed into temporal, insecure employment. The second is externalisation through labour brokerage or subcontracting, where employment ties are severed by devolving employment to a third party (Von Holdt \& Webster, 2005). Informalisation from below is the expansion in survivalist strategies employed in the global South by large sections of the population whose national economies are unable to provide jobs. State withdrawal from employment creation and the failure of private sector employment creation to match the employment demands of job seekers like new entrants into the labour market, ex-state workers, and migrants lead to the expansion of the informal economy and the contraction of the formal (Von Holdt \& Webster, 2005; Munck, 2002; Overton, 2000; Ninsin, 1991). Drastic cuts in welfare provi- 
sioning also fuel informalisation as people search for alternative sources to meet their needs outside mainstream structures.

Emerging from these two trends of informalisation from above and below, is the increasing precariousness of working conditions and the accompanying lack of employment security (Webster, 2005). Employment deregulation or flexibilisation triggered by enterprise competition for global market share has been achieved through cost cutting and technology intensive production. Improved technology limits employment avenues, while cost-cutting measures, through arrangements like casualisation, outsourcing and sub-contracting result in less formal employment forms. The tendency is for firms to remain small concentrating on core businesses while contracting several even smaller enterprises to conduct what they classify as peripheral activities. Workers find themselves with lower incomes and come under pressure to earn more to cover daily needs and make up for lost state welfare support through part-time, temporary or self-employment (Smith \& Stenning, 2006; Lyons \& Snoxell, 2005). Growth in informal employment has been triggered mainly by survival as people take to traditional forms of economic activities and self provisioning to supply their needs and expand incomes.

Expansion in the informal economy is pervasive and features in all economies: developing, transition and developed countries under a variety of forms. Lyons and Snoxell (2005) explain that while in developing countries rapid urban expansion accompanied by limited job creation has led to a rapid growth in informal employment, in developed countries it is the recourse to part-time, temporary jobs and selfemployment to supplement incomes that has generated growth in the informal economy. For transition economies of Eastern Europe the growth fuelling factor has been the need to find alternative employment to supplement dwindling incomes and state withdrawal from welfare provisioning. Low income of workers has also triggered a demand for cheap goods and services especially in developing countries such as those of Africa. The emerging employment forms go to directly subsidise capital through workplace cost cutting reforms or indirectly as workers resort to informal employment forms to supplement their incomes or create their own jobs to solve problems of unemployment and meet low income demands for cheap goods and services.

The experience everywhere shows that informal employment serves to redraft nonmarket forms of production into the globalised economy to subsidise capitalism (Smith \& Stenning, 2006; Alenjandro, 2002; Munck, 2002; Overton, 2000). The more apparent forms occur within the formal enterprises' recourse to informal labour, outsourcing and sub-contracting. In traditional informal employment types like selfemployment and subsistence production the appropriation of informal economic labour power is indirect through self exploitation (Smith \& Stenning, 2006; Overton, 2000). Though unregulated the informal economy forms part of global capital and serves its interests. These trends suggest a process of employment informalisation 
and less of an expansion in the informal economy as a distinct sector (Webster, 2005).

A significant feature of employment informalisation is its gendered and class nature (Williams \& Round, 2007; Ligthelm, 2005; Gough, Tipple, \& Napier, 2003). Informal employment forms reveal a high concentration of women, occupational sex segregation and gender wage differentials (Munck, 2002, p. 114). Ghanaian labour force statistics reveal greater female participation in informal employment types than males, with women more likely to be engaged in less secure and low income activities (Britwum \& Martins, 2008). William and Round in their discussions on a study of Ukraine concluded that low income groups are more likely to engage in more precarious forms of informal employment for survival than middle income families. Gough et al also made similar conclusions in their Ghanaian and South African studies. Overton's discussion of the limits of production for use catalogued a range of 'social and natural factors that affect people's ability to fend for themselves' (Overton, 2000, p. 38). Ability to benefit from one's engagement in informal employment is determined largely by one's social positioning (Philip, 2005).

The significance of the increasing informalisation of work for trade unions lies in the expansion of work forms where union coverage is low, creating what Webster describes as the representation gap (Webster, 2005). For trade unions the challenges come in two directions: their claim to be workers' representatives when the average union member is no longer synonymous with the average worker; and secondly, that their default mode of organisation is ineffective for organising workers in the sector of the economy where they dominate. While the development of capitalism in the West was achieved through the separation of work from its social ties, under globalisation, work transformation is predicated on increasing precariousness of employment conditions and the distancing of direct producers from the exploiters of their labour. Union organisation developed on a clear identification of workers and their employers. Changes in work forms and employment trends pose their own challenges to trade union organisation and hold serious questions for the potential of informal economy to provide answers to employment problems of Ghana.

\subsection{INFORMAL EMPLOYMENT TYPES}

Several informal employment types are created as a result of the different growth fuelling factors. The challenge in defining the informal economy has been blamed on efforts to characterise a heterogeneous range of economic activities bounded by a corresponding diverse range of employment relations (Dasgupta, 2003; Devey, Skinner, \& Valodia, 2003). The variations in definition produce different frameworks for classifying employment types as informal. Informal employment forms are determined by national economic situations which in turn determine types of production relations. Employment status, economic location, income generating capacity, enterprise size, physical location of economic activity, regularity and ille- 
gality, constitute some of the standards used to categorise informal economy activities yielding a broad range of categories that incorporate several economic activities that are dissimilar in a number of ways (Cooke, 2006; Lyons \& Snoxell, 2005; Dasgupta, 2003). In all the employment forms however the underlying similarities are the total absence of employment and social security as well as protection for workers' rights.

The various formulations of informal employment types yield categories like selfprovisioning or subsistence production, unpaid community work and paid informal work (Williams C. C., 2008; Overton, 2000). Here the distinguishing feature is the motive for undertaking a production activity, whether self-serving or for profit. Informal economic activities are those undertaken for self-consumption, exchange within kin or community groups, or for money (Williams, 2008). Others following the lead of the ILO limit informal economic activities to urban space for sheer expediency resulting in two categories of informal employment types, service and manufacturing (Dasgupta, 2003). Cooke utilises the levels of employment permanency and worker's employment status to distinguish types of informal employment in China (2006). Informal employment types are either full-time casual work, flexible employment, temporary or seasonal work undertaken in both formal and informal economic enterprises. Others posit informality as synonymous with the traditional economy or traditional modes of production, non-waged, non-market or non-regulated employment forms (Overton, 2000; Dasgupta, 2003; Cooke, 2006; Reddy, 2007). For Von Holdt and Webster however the distinguishing feature is whether one is making or earning a living.

Informal employment forms are based in both the formal and informal economy. Their characteristic forms of production relations and employment practices highlight the fact that informal employment types are determined by employment practices and less by specific activities that workers are engaged in. Aksikas insists that there is marked similarity in employment activities performed in formal and informal economic spheres however, it is in the practices associated with employment conditions, production relations, production levels and technology that the differences must be positioned (2007). Philip's work on the rural enterprises in South Africa also reveals the similarities in informal and formal economy work. The final agreement is that it is the general instability of employment, the low observance of labour standards, low incomes, and lack of institutional support that distinguish informal from formal employment types (Reddy, 2007; Von Holdt \& Webster, 2005; Philip, 2005). Von Holdt and Webster's categorisation of work into three distinct zones of core, non-core and the periphery based on the relations with the formal economy are useful in determining the relationships between the various economic sectors. They however give pre-eminence to the formal in national economies (2005). In the Ghanaian situation, where the formal economy employment was limited to a small section of the population based mainly in public enterprises, this categorisation is inadequate. Their typology also fails to cover public sector cost 
cutting measures that fuel informalisation. Again the conceptual separation of work into zones fails to highlight the interconnectedness of the formal and informal especially in the formal space.

Table 5.2 below presents a typology of informal employment types by approaching informality as a practice. The categorisation is based on identifying production relations that give rise to informality and the accompanying employment relations that arise. This is done by concentrating on the relationship between formal and informal economies and also locating informal employment forms within formal enterprises. As mentioned earlier, under globalisation informal employment is no longer the prerogative of traditional rural economy or survivalist urban cities of African countries. Informal employment permeates both public and formal private enterprises hitherto the bastions of formality. Flexibilisation, casualisation and externalisation produce informal employment in public and state owned enterprises as part of strategies to limit government spending. Similarly private enterprises utilise subcontracting, outsourcing and contract workers secured through labour brokers or employment agencies to reduce labour cost and to remain 'competitive'. As firm size reduces, reliance on informal employment forms increases and in small scale firms and traditional informal economy enterprises, the predominant labour types are informal workers (Table 5.2).

Table 5.2: Typifying informal employment

\begin{tabular}{|c|c|c|c|}
\hline \multirow{2}{*}{$\begin{array}{l}\text { Employment } \\
\text { Context }\end{array}$} & \multicolumn{2}{|c|}{ Formal economy based } & Informal economy based \\
\hline & Public/Private & Private & Private \\
\hline Size & Large & Medium & Small \\
\hline $\begin{array}{l}\text { Production } \\
\text { forms }\end{array}$ & $\begin{array}{l}\text { Flexibilisation, } \\
\text { Casualistion }\end{array}$ & Sub-contracting, Outsourcing & $\begin{array}{l}\text { Self-employment, Subsistence } \\
\text { production }\end{array}$ \\
\hline $\begin{array}{l}\text { Employment } \\
\text { forms }\end{array}$ & $\begin{array}{l}\text { Contractor, } \\
\text { Labour broker, } \\
\text { Casual, } \\
\text { Temporal, } \\
\text { Seasonal, } \\
\text { Part-time, }\end{array}$ & $\begin{array}{l}\text { Contractor, } \\
\text { Labour broker } \\
\text { Undeclared waged worker }\end{array}$ & $\begin{array}{l}\text { Independent service provider, } \\
\text { Self-employed, } \\
\text { Self-provisioning }\end{array}$ \\
\hline
\end{tabular}

Source: Field data, 2007-2008

Informal work ranged from the waged employment with reducing levels of employment security for workers employed by labour brokers and contractors, through casual, temporal, flexible and seasonal workers, to independent service providers and unpaid family members (Table 5.2). Flexible and casual employment types in formal enterprises were governed by both formal and informal rules that have eroded labour benefits that come with permanent employment (Table 5.2). These are the forms that have borne the title atypical employment. Sub-contracting 
and outsourcing are contractual firm level relations that produce informal employment conditions. Contractors or labour hire agents rely heavily on informal employment conditions to serve the needs of large public or private firms. Business practices might be formal but employment conditions remain informal. At the extreme end are located the classical informal economy based employment types of self-employed, apprentices, cooperative labour pools and family labour, the forms normally described as survivalist and aptly captured as self exploitation. Selfemployment and subsistence employment are the usual informal types located within the informal economic sphere. Here there is reliance on forms of labour that range from waged to non-waged with the non-waged forms like family or household labour, apprentices, self-employed and reciprocal labour forms dominating (Table 5.2).

Categorising informal employment through an examination of production relations allows the discerning of varying forms of employment practices and their accompanying employment conditions. This is because unveiling forms of production relations between the formal and informal economic divide enables one to interrogate workers' rights. When production relations are explored at the enterprise level within informal economy based micro enterprises, it becomes possible to transcend forms of intra enterprise exploitation and how other forms of social relations serve to mask these relations. Examining production relations in the various workplaces should provide unions with answers on to how to engage different employment forms both waged and unwaged in formal and informal spaces. Unions will be able to focus on employment conditions and factors undermining the employment conditions, so as to direct their efforts at finding solutions and making the connection between workers in the informal/formal economy divide.

\subsection{THE INFORMAL IN GHANA'S ECONOMY}

Ghana's economy has three main sectors, the formal, rural agriculture and urban informal (Britwum \& Martens, 2008). The rural agricultural and urban informal sectors are dominated by informal employment types and the formal has varying degrees of informalisation as discussed above. Rural and urban informal employment are made up of own account or self-employed workers, independent service providers, waged and non-waged employees. Self-employment dominates the informal economy making up $66 \%$ of the working age population. Non-waged employees are either family or household members like wives, children, dependent household members or apprentices. The informal economy employment has been expanding in recent years. In 1991 for example, the proportion of the Ghanaian workforce in informal economy was $80 \%$. This increased to $86 \%$ in 2000 (Britwum, Ghartey, \& Agbesinyale, 2006). Informal economy also serves as the main employment provider recording a growth rate of $5.6 \%$ in 2000 , while the formal economy grew at $1 \%$ (Baah, n.d; Ghana Statistical Service, 2002). 
Ghana's pre-colonial economy was largely subsistence, with local and international trade in agricultural products, gold, salt and cloth (Hymer, 1970). Of course there was also the callous trans-Atlantic human trade in slaves that lasted over three hundred years whose impact on the development of African countries such as Ghana is yet to be estimated. The existing land tenure system lent itself to support entrepreneurship in cash crop production for export without recourse to plantation production forms. Direct access to free land made plantation agriculture uncompetitive and the production levels within small holding of peasant farmers were able to meet the demands of European industry (Hymer, 1970).

Colonial rule changed the largely unwaged employment forms with the introduction of formal sector employment. These forms of employment were found in the colonial civil service, construction and rail transport, retailing outlets and the extractive mining concerns. Cowan states that in 1952, the colonial service employed 37\% of the 250,000 waged labour force and mining 16\% (1960). The emerging urban spaces in towns and mining enclaves served as the location for formal economy workers. Social services like healthcare and education also provided avenues for formal employment. These forms of employment however were limited to few Ghanaians who were mainly men (ibid).

Formal employment received a boost after independence (1957-1965) with the adoption of the import substitution industrialisation and 'Africanisation' policies. These translated into the expansion of the civil service, infrastructure and social services like education and healthcare (ISSER/DPPC, 1996; Cowan, 1960). The postindependence economic policies increased public sector employment by $198 \%$. Over a period of 8 years the number of workers employed directly by the GOG in various positions was 184,000. This number increased to 397,000 in the early 1980s (Britwum \& Martens, 2008). These impressive increases however, were unable to absorb the Ghanaian labour force and informal employment still remained the dominant employment. The rate of expansion in the formal employment suffered a decline with the first military coup that overthrew the CPP regime. The military junta (National Liberation Council) that took over power and its civilian successor, the Progress Party, worked to overturn the economic policies of the CPP and halted the industrialisation programme and expansion in physical and social infrastructure (Britwum \& Martens, 2008). Subsequent governments' efforts at reversing this trend were thwarted by corruption and mismanagement that caused the total collapse of the Ghanaian economy in the 1970s (Britwum \& Martens, 2008; Britwum A. O., 2007). The introduction of economic reforms in 1983 entrenched the position of the informal economy as the major employer in Ghana.

Davies' assertion of a base consensus, that the crises of the 1980s inverted the relative structural positions of the formal and informal sector, largely reflects events in Ghana (Davies, 2004). Ghana was second to Tanzania in terms of the number of prereform public enterprises. Ghana had an estimated 300 state owned enterprises in 
the mid 1980s, by 1991 however, over 200 of these enterprises had been divested (Aryeetey \& Goldstein, 2000). The introduction of World Bank/IMF economic reforms in 1983 led to the expulsion of workers from the public and state owned enterprises causing a reduction in public sector based formal employment from 397,000 in 1985 to 156,000 in 1991 (Baah, n.d; Britwum \& Martens, 2008). Most of the retrenched workers found refuge in the informal economy.

Table 5.3 Workforce distribution by industry in formal and informal Economies

\begin{tabular}{|l|c|c|}
\hline Industry & Informal (\%) & Formal (\%) \\
\hline Agriculture & 56.0 & 10.0 \\
\hline Mining & 0.13 & 11.0 \\
\hline Manufacturing & 13.0 & 1.0 \\
\hline Utility & 0.13 & 5.0 \\
\hline Construction & 1.34 & 7.0 \\
\hline Trade & 24.0 & 11.0 \\
\hline Transport & 1.0 & 5.0 \\
\hline Finance & 0.1 & 46.0 \\
\hline Commercial \& Personal services & 4.3 & 100.0 \\
\hline Total & 100.0 & 25 \\
\hline$\%$ Labour force Female & 57 & 75 \\
\hline$\%$ Labour force Male & 43 & \\
\hline
\end{tabular}

Source: GSS; 2002

The last population census figures revealed that informal employment dominates in several industrial sectors such as agriculture, manufacturing, and trade in the Ghanaian economy (see Table 5.3). The female labour force is larger than male (Table 5.3). In addition females tend to work in more precarious forms of informal employment and are tied by forms of production relations which submerge their rights as workers (Britwum A. O., 2009).

The loss of formal employment in the 1980s and 1990s caused a sharp fall in union membership by 40\% (Adu-Amankwah \& Tutu, 1997; Panford, 1996). Out of an estimated workforce of over 9 million 1.5 million are employed in the formal economy. The GTUC covers 350,000. By mid 1990s trade union membership was threatened by the rapid expansion of the informal economy and the contraction of the formal. The GTUC and the national unions had to respond and they did. The next section explores the GTUC and the national unions' work in the Ghanaian informal economy. 


\subsection{ORGANISING IN THE INFORMAL ECONOMY}

The GTUC's direct engagement with informal economy workers began with the affiliation of the GPRTU in 1967. The GPRTU, originally the Motor Drivers Union in 1935, was set up to mobilise private road motor transport operators in the then Gold Coast (Britwum A. O., 2007). It stands out from the other national union affiliates because of the employment conditions of its members. Its members are a mixture of employers and employees (vehicle owners, owner-drivers and employee-drivers). As a result, collective bargaining, does not feature as a union concern. In addition, a substantial proportion of members have irregular incomes. Only members employed by the union have regular incomes ${ }^{44}$.

Philip's observation that for self-employed informal economy workers, enterprise viability is dependent on effective management of their representative organs and not democratic systems is largely true for the GPRTU (Philip, 2005). The union was formed out of a need to regulate the operations of private transport workers and provide a system for social and employment welfare. Work regulation is achieved through strict rules and conventions that guide the conduct of drivers and porters at the loading points ${ }^{45}$. The GPRTU had an elaborate system of union guards (a paramilitary organ) which monitored travelling drivers to ensure adherence to union rules and road traffic regulations. This unit was proscribed with the coming into power of the NPP government in 2001.46 Union leaders however reported regulation of drivers conduct as a role played by union. Each location visited insisted that they had norms about dress codes and drink driving.

Membership welfare, another key concern, is served through contributions to members in times of high income need like, marriage, child naming, ill health and bereavement. Various branches operate credit schemes for their members. There is also a scheme for supporting retired or out-of-work drivers. This was termed 'chop money' where retired drivers who hung around their original loading points are given some pocket money at the end of the day. ${ }^{47}$ In a situation of irregular income, even a day out of work for a driver can have serious implications for subsistence. Variable income means that only 15,000 of the 80,000 union members pay dues regularly. ${ }^{48}$

In 2002 the Makola Traders Union originally affiliated to the PSWU was passed on to the GTUC for direct affiliation. The Madina Traders' Union formed in 1999 was

\footnotetext{
${ }^{44}$ Interview with GPRTU General Secretary October, 2007

${ }^{45}$ Known as 'lorry stations'; they are designated points in towns and cities where travellers go to board vehicles

${ }^{46}$ Interview with National union executives, November, 2007

${ }^{47}$ The Novotel Branch in Accra for example give such retired drivers GH $\$ 1.00$ a day (this was equivalent to $€ 0.72)$

${ }^{48}$ Interview with National union executive, November, 2007
} 
affiliated to the GTUC in 2005. These two were initially associational members of the GTUC till August, 2008 when they were granted full national union status. ${ }^{4}$ These groups operate more as welfare associations to support their members. They however, are smaller in comparison to the GPRTU and their members are based in Accra, the national capital.

The first formal economy based national union to sign on informal economy members was the PSWU which in 1968 granted the Lotto Receivers' Union's request for union affiliation. Lotto receivers are contract workers attached to the state Department of National Lotteries. They earn $30 \%$ of the sale of lotto coupons. The experiment of union affiliation failed however and in 1996 the Lotto Receivers' Union broke away from the PSWU50. In 1987 the Ghana Union of Photographers' requested for and was also granted affiliation to the PSWU. They continue to maintain their affiliation.

GAWU in 1979 became the second formal economy based national union to cover workers in the informal economy. Unlike PSWU, GAWU initiated the process to organise informal economy workers. Two coinciding national and international factors prompted GAWU to organise the rural self-employed workers. Private plantation agriculture began a process of informalisation in the 1960s with the adoption of small holders and out-growers' schemes. Such schemes enabled the oil palm, rubber and cotton plantations to expand without additional cost of worker overheads to the enterprises. There emerged an expanding group of agricultural workers who on the surface were self-employed but in reality were in formalised contractual work relations with the nucleus plantations. ${ }^{51}$ The plantations provided them agricultural inputs like seedlings, agro-chemicals, tools as well as extension services on credit. The costs of inputs were deducted by check-off from payments that the enterprise made for crops received from farmers. The determination of produce costs was the prerogative of the plantation companies. They adopted a punitive system of fines and withholding payments for crops supplied to compel farmers to sell their products to them only. ${ }^{52}$ The ILO's determination to promote and extend the fundamental rights to organise to all workers, which was subsequently backed by the adoption of Convention 141 on the organisation of all rural workers, provided the international motivation to organise informal economy workers. The enthusiasm for organising rural workers waned, but was revived in 1996, when GAWU began more concerted efforts to cover the rural self-employed. ${ }^{53}$

\footnotetext{
49 See Ghanaian Times, August, 28, 2008 article titled 'GTUC Admits 4 New Unions'

${ }^{50}$ Interviews with the General Secretary of the National Lotto Receivers' Union, and PSWU November 2007

${ }^{51}$ Interview with Deputy General Secretary of GAWU, December 2007

52 See also Britwum et al, 2006

${ }^{53}$ Interview with Deputy General Secretary of GAWU, December 2007
} 
Rural self-employed members of GAWU are either community or socio-economic groups with or without specific relations with a formal enterprise. The community groups are made up of farmers within given rural farming communities who produce a wide range of crops. The socio-economic groups are farmers' groups with a specific relation to an enterprise, like small holders and out-growers or farmers on irrigation schemes. This gives GAWU the following groups of rural self-employed members:

- Socio-economic units in direct relations with an enterprise (small holders and out-growers);

- Community groups with no direct relations with a formal enterprise (peasant and tenant farmers);

- Irrigation farmers (who may or may not have direct relations with a formal enterprise $)^{54}$.

GAWU covers a wide range of rural self-employed workers in the form of peasant and tenant farmers, beekeepers, food and fish processors, pito brewers, local soap manufacturers and charcoal burners. The membership profile of GAWU has undergone transformation from formal-worker dominated union to an informal-worker dominated membership. In 1980 5\% of GAWU's membership was made up of the rural self-employed. By 2005 the proportion of rural self employed membership had increased to 53\% (Britwum A. O., 2007).

The ICU, as a result of its wide jurisdiction, covers informal economy groups in the hair, textile, craft, tourism, and domestic service sectors. The specific groups are:

i. The Hair Sector;

a. Ghana Hairdressers' and Beauticians' Association (GHABA),

b. Ghana Progressive Hairdressers' and Beauticians' Association (GPHABA),

c. United Hairdressers' Association of Ghana (UHAG), and the

d. Ghana National Association of Barbers and Barbering Saloon Owners (GABBSO).

ii. Textile Sector: Smock weavers

iii. Craft Producers: Basket Weavers and Leather Manufacturers;

iv. Domestic Workers: Domestic Workers' Union (DWU) and

v. Tourism: Traditional Caterers ${ }^{55}$.

ICU's encounter with the informal economy workers began in 1990 when GHABA approached it for affiliation. GHABA was formed in 1972 as a trade association of professional hairdressers with membership throughout the country. Its peculiar identity is its female dominance. In November 2007 only 40 out of its 6,000 members

\footnotetext{
${ }^{54}$ Interview with GAWU Informal Economy Desk Officer, November, 2007

${ }^{55}$ Interview with ICU Informal Economy Desk Officers, November, 2007
} 
were males. ${ }^{56}$ GHABA and GABBSO, the latter, a male dominated group, formed an umbrella organisation the Ghana Federation for Professional Hair Dressers, Cosmetology and Barbers (GHAFEB) which is dormant owing to the dwindling membership of GABBSO. GPHABA and UHAG are splinter groups which emerged during the six-year long leadership crisis that GHABA suffered in the late 1990s and early 2000s (Britwum A. O., 2008). The DWU, BATMAG, the Bolga Weavers' Association and the Traditional Caterers' Association are groups that ICU organised after 1999. ICU's organisational efforts in the informal economy received a boost from the funding support of the LO/FTF Denmark ${ }^{57}$.

The TWU began organisational work in the informal economy in 1996, first organising chain saw operators and later Small-Scale Carpenters, now Woodworkers' Association of Ghana. Other informal economy groups organised by the TWU are wood carvers of the Aburi Industrial Centre and the Cane and Rattan Weavers. The TWU has however lost members due state policy and numerous micro-credit schemes. Groups lost by the TWU include its small-scale carpenters, Charcoal Producers of Kintampo, Canoe Carvers and Lumber Sellers. Government policy enacted to protect Ghana's rainforests resulted in a ban on chain saw operations and killed the chain saw operators association, by either putting members out of job or driving them underground. The numerous credit schemes that seem to provide an answer to the immediate need for credit have also claimed most of its small-scale carpenters $^{58}$. It now retains only two branches of the Wood Workers Associations at Winneba and Swedru in the Central Region.

The Local Government Workers' Union (LGWU) began covering informal economy workers in 2001 when it granted affiliation to the Global Handicraft Association. The group was moved to seek union affiliation under threat of ejection from the local government authorities. The second informal economy group, the Darkuman Artisans' Association, however, was organised by the LGWU in 2006. Efforts to organise the butchers' group failed when the membership split along ethnic lines.

The late 1990s and early 2000s saw more concerted efforts by GTUC to coordinate the expansion of national unions into the informal economy. The 5th Quadrennial Delegates' Conference's (QDC) of the GTUC in 1996 adopted a policy to direct union organisation in the informal economy and set up a coordinating desk. The Informal Economy Desk, situated within the Organisational Department of the GTUC, began work in 2000 (Britwum A. O., 2007).

\footnotetext{
${ }^{56}$ Interview with ICU Informal Economy Desk Officers and national leadership of GHABA

${ }^{57}$ Interview with ICU Informal Economy Desk Officers and see also Britwum A. O., 2008.

${ }^{58}$ Interviews with TWU General Secretary and Informal Economy
} 
In 1996 GTUC pronounced a decision to set up informal economy desk to facilitate organising in informal economy. A meeting of all Deputy General-Secretaries (they are in charge of operations in their respective unions) was held to discuss modalities and how to proceed. In October the informal economy Desk was set up and an officer appointed to take charge. In August 2004 the 7th QDC adopted a policy to allow more informal economy groups to be directly affiliated to the GTUC as associational members. The GTUC sets the framework for union engagement in the informal economy in its four-year policies. National unions are expected to identify and organise informal economy workers that fall within their jurisdiction. Informal economy groups which request for union affiliation and have no identified jurisdiction are given direct affiliation to the GTUC, first as associational members, and later as affiliate national unions. ${ }^{59}$

The GTUC's 2004-2008 medium term policy goals were to extend union coverage to the informal economy and ensure the application of minimum labour standards. ${ }^{60}$ Strategies outlined included, developing links with existing informal economy associations, designing programmes and activities to respond to the identified needs of workers in the informal economy and encouraging unorganised informal economy workers to form associations. Other policy strategies consisted in developing a network of national unions' informal economy Desk Officers and assist them to develop skills for organisational work in the informal economy. A final strategy sought to advocate for the development of a National Policy on the informal economy.

In terms of levels and enthusiasm of organising informal economy workers, six groups of national unions can be discerned (Table 5.4). There are those that are wholly informal economy based, like the GPRTU, Makola Traders' Union and the Madina Traders' Union. The second group consists of formal economy based unions like GAWU, TWU, LGWU, PSWU and ICU with active engagement with informal economy workers as members. The third group of unions, the CBMWU and the CWU, have lost contact with groups they formerly organised. The fourth, the National Union of Seamen and the GTPCWU, are unions whose earlier initiatives at organising in the informal economy failed. The fifth group, labelled prospecting unions, are yet to offer union coverage to groups they have identified as possible union members. These unions, the MDU, HSWU and PUWU, doubt their capacity to effectively provide meaningful union coverage to the informal economy groups that they have identified (Table 5.4). The last, TEWU, does not have any plans for venturing into the informal economy. This is partly because the demands from their traditional membership do not allow space for the union to take on board informal economy groups or they have no corresponding identifiable jurisdiction in the in-

\footnotetext{
${ }^{59}$ Interview with former Informal Economy Desk Officer, October 2007

${ }^{60}$ See GTUC policy document titled 'Meeting the challenges of the Quadrennial: 2004-2008-Medium Term Policies of the Ghana Trades Union Congress; August 2004'
} 
formal economy. General Secretary explained that 'there is no informality in Ghana's educational sector' ${ }^{\prime}{ }^{1}$.

Table 5.4 Profile of Unions' Coverage in the Informal Economy

\begin{tabular}{|c|c|c|}
\hline Intensity & Union & Groups or members \\
\hline \multirow{3}{*}{$\begin{array}{l}\text { Informal } \\
\text { economy } \\
\text { based }\end{array}$} & GPRTU & Membership spread throughout country \\
\hline & Makola Traders' Union & Membership based in Accra only \\
\hline & Madina Traders' Union & Membership based in Accra only \\
\hline \multirow[t]{4}{*}{ Active } & GAWU & $\begin{array}{l}\text { Community groups } \\
\text { Economic groups } \\
\text { Out-growers }\end{array}$ \\
\hline & ICU & $\begin{array}{l}\text { The Hair Sector; } \\
\text { Ghana Hairdressers' and Beauticians' Association } \\
\text { Ghana Progressive Hairdressers' and Beauticians' Association } \\
\text { United Hairdressers' Association of Ghana, and the } \\
\text { Ghana National Association of Barbers and Barbering Saloon } \\
\text { Owners } \\
\text { Textile Sector; } \\
\text { Basket Weavers and Leather Manufacturers; } \\
\text { Domestic Workers; (Domestic Workers' Union) } \\
\text { Traditional Caterers }\end{array}$ \\
\hline & TWU & $\begin{array}{l}\text {-Wood Workers Association-Winneba \& Swedru } \\
\text {-Aburi Industrial Centre }\end{array}$ \\
\hline & LGWU & $\begin{array}{l}\text {-Darkuman P\&T Artisans ‘ Association } \\
\text {-Global Handicraft Association }\end{array}$ \\
\hline \multirow[t]{3}{*}{ Inactive } & CBMWU & $\begin{array}{l}\text {-Madina Artisans' Association } \\
\text {-Construction Workers of Great Lakes Area } \\
\end{array}$ \\
\hline & PSWU & Ghana Union of Professional Photographers \\
\hline & CWU & $\begin{array}{l}\text { General Electronics Servicing and Technicians' Association } \\
\text { Communication centre operators }\end{array}$ \\
\hline \multirow{3}{*}{$\begin{array}{l}\text { Failed At- } \\
\text { tempt }\end{array}$} & PSWU & National Lotto Receivers' Union \\
\hline & NUS & Canoe Fishermen \\
\hline & GTPCWU & Filling station attendants \\
\hline \multirow[t]{4}{*}{ Prospecting } & MDU & $\begin{array}{l}\text {-Jewhi Wharf Boat and Canoe Owners } \\
\text {-Tema Canoe fishermen } \\
\text {-Volta Lake Yam Sellers' Association } \\
\end{array}$ \\
\hline & GMWU & $\begin{array}{l}\text {-Songhor Mine Workers } \\
\text {-Small Scale Miners } \\
\end{array}$ \\
\hline & HSWU & $\begin{array}{l}\text {-Traditional Birth Attendants, } \\
\text {-Wanzams, } \\
\text {-Herbal Medicine Practitioners } \\
\end{array}$ \\
\hline & PUWU & $\begin{array}{l}\text {-Private Securities } \\
\text {-Borehole Drillers } \\
\text {-Electrical Contractors } \\
\text {-Sachet Water Producers \& Sellers } \\
\text {-Meter Readers } \\
\end{array}$ \\
\hline \multirow[t]{3}{*}{ No Interest } & TEWU & No informality in education \\
\hline & RWU and REU & No capacity to organise informal economy workers \\
\hline & UNICOF & Young union \\
\hline
\end{tabular}

Source: fieldwork 2007-2008 and Britwum, 2008.

${ }^{61}$ Interview with TEWU General Secretary, 2008 
Most national unions recognise the potential of organising informal economy workers to their strength, credibility and political outlook. A series of obstacles tend to dampen union enthusiasm for organising informal economy workers. These include the cost of organising and the low financial returns in terms of dues from informal economy workers, the difficulty in maintaining contact with workers who have no fixed place of work, or located in highly dispersed work sites, high job insecurity and employer hostility (Britwum A. O., 2008). The returns on investments in organising informal economy workers tend to discourage financially handicapped national unions. Organisational work demands funding for meetings, travel cost for union organisers to meet with informal economy groups as well as informal economy groups to interact with union leaders. Low and irregular income means that informal economy groups are not in a position to pay unions dues at levels that will cover investments made for their organisation ${ }^{62}$.

NGO activities with informal economy groups have created a fixation on credit, pushing informal economy workers to link union membership with credit access. Development oriented NGOs operating with donor funds tend to invest in infrastructure and social projects with others providing micro credit. In some communities, politicians have hi-jacked informal economy groups organised by unions through co-opting their leaders. Such practices create the impression among certain informal economy workers that contact with formal sector organisations or urban based groups should provide easy access to money. Union inability to deliver cash or worse still their demand for dues create disaffection and have worked to dismantle some groups or discourage group formation for union affiliation. ${ }^{63}$

The unionisation of informal economy workers into the GTUC and its national unions began on the initiative of informal economy groups long before the introduction of structural adjustment induced union membership decline. Informal economy groups affiliated to trade unions presented a high desire for trade union coverage and maintaining union affiliation. The enthusiasm for union affiliation of informal economy workers was sometimes unmatched by the trade union desire to expand into the informal economy. The informal economy groups that initiated union membership are among the most vibrant groups within the unions. Webster has described barriers to organising informal economy workers as discordant and factors promoting organisation as the axes of commonalities (Webster, 2005). Clearly in the situation of the GTUC and its affiliates the axes of commonalities for organising far outweigh the discordant ones for the informal economy groups. Discordant factors were rather within the unions and not the informal economy groups.

\footnotetext{
${ }^{62}$ Interviews with Head of Education Department and the GTUC Informal Economy Desk Officer

${ }^{63}$ Interview with Deputy General Secretary and Informal Economy Desk officer of GAWU 2007
} 


\subsection{UNIONS AND INFORMALISATION}

Workplace and enterprise restructuring have been constant features of the Ghanaian employment scene since economic reform. They take the form of mergers, takeovers, downsizing, sub-contracting or outsourcing. Accompanying enterprise restructuring is labour informalisation. The specific nature of work informalisation varies across sub-sectors within the Ghanaian economy and the case study unions, as a result of their economic locations, have been faced with different forms of informalisation. This section examines modes of informalisation the six case study national unions are experiencing in the formal economy enterprises where they organise. This section uses information derived mainly from interviews with the General Secretaries of these selected national unions.

The CBMWU as its name suggests draws its members from the construction industry. Construction was originally dominated by public enterprises like the Public Works Department, State Construction Company, the Ghana Highways Authority and the Architectural and Engineering Services Corporation. These organisations undertook to construct and maintain physical structures like buildings, roads and bridges. Under economic reform these corporations have been restructured, downsized and major sections privatised. State monopoly over construction in Ghana has been broken and state owned enterprises have to compete with private enterprises for public tender. Ghanaian construction is dominated by private foreign contractors.

The main factor fuelling informalisation in construction is privatisation and the recourse of private enterprises to casualisation and externalisation. Private contractors execute projects through sub-contracting and outsourcing. Most contractors in Ghana do not engage workers directly. They use casual and contract labour to execute their core tasks. Workers in direct employment are mainly casuals or temporal workers on short-term contracts who are continuously re-employed in order for employers to remain within the confines of the Labour Act, which bans short-term employment beyond 6 months. During fieldwork, one came across casual workers who had been in the employment of some construction firms for between 18 months to five years. They were given short-term employment and re-employed after the term had lapsed. It was sometimes very difficult to tell who was employing workers at a construction site. Union leaders complained of employers resorting to restructuring or downsizing to fire workers at will. Most construction industries, they explained, had few core staff. For example the Dutch firm (Spaans Babcock) constructing a water treatment plant at Mankesim, in the Central Region, maintains a core staff of five management personnel two of whom are Ghanaians. Their 325 construction workers fall into two categories: permanent workers directly employed by the company for 30 months and the rest supplied by an employment agency or 
labour broker, A Best Limited. ${ }^{64}$ Chinese construction firms use casual labour and have no respect for conventions reached between unions and the Ghana Contractors Association. The construction industry as a result is now highly informal with few permanent workers. The majority of workers are either temporal, casual or contract workers supplied by employment agencies. ${ }^{65}$

Ghanaian labour legislation discourages short-term employment beyond six months, however, in terms of labour rights protection, union leaders insisted that the law is discriminatory. The Labour Act, 651, 2003 classification of workers by jobtenure, and grants permanent workers better protection. Union leaders explained that under the previous labour legislation, IRA 299, unions could spread negotiated conditions of work to cover all categories of employees irrespective of their employment tenure. The current Labour Act limits the coverage of union negotiated benefits to permanent workers only. Union leaders insist that the Labour Act, Act 651 was designed to favour investors and not protect Ghanaian workers. They have every reason to believe so since the Labour Act provides no protection for nonpermanent workers which employers increasingly prefer to use.

National leaders complained that short-term employees like casuals, temporary and contract workers, have little job protection and can be fired at will. Such labour forms are difficult to organise for several reasons. Their precarious employment status makes them less ready to submit to union organisation for fear of losing their jobs. Secondly, their short-term labour contract makes unionisation impracticable. The process of trade union registration and certification in Ghana is slow and its attendant bureaucratic processes unsuitable for short-term employment contracts that characterise the construction industry. The duration of employment contracts range from 4 to 36 months. Unions first have to get workers to sign forms registering their intention to join the union. The signed forms are submitted to the National Labour Office which sends an officer to the workplace to meet with the workers to verify the authenticity of the signed forms and inform management of the intention of workers. Afterwards the workers meet to elect their leaders and wait for their union certification which empowers them to enter into negotiation with their employers. Till the certificate that gives them legal backing as a union has been issued, the national union that got workers to sign on their intention for union membership has no power to protect these workers. It is at this stage that workers are most vulnerable. Before the union certificates are issued local leaders are isolated, victimised, some sacked or harassed to such an extent that they resign voluntarily or withdraw their intention to join the unions. In some cases workers have not faced the wrath of their employers, but their construction contract had lapsed long before the certifica-

\footnotetext{
${ }^{64}$ Interview with management, March, 2008

${ }^{65}$ Gokel and Vormawor (2004) observed that the construction and maritime industries had the greatest levels of casual labour employment.
} 
tion for unionisation was issued ${ }^{66}$. Here, as explained by Von Holdt and Webster (2005) non-permanency of employment pushes workers out of legislative protection and places them at the mercy of employers, hindering effective organisation.

For the CBMWU informalisation was predicated on privatisation and the attendant cost cutting by companies to remain competitive. Cost cutting measures were mainly directed at keeping labour cost low through various arrangements to engage labour only when required and attempts to diffuse any efforts by workers to demand improved working conditions. The former was achieved through short-term labour contracts or casualisation; and the latter through externalisation to avoid unionisation. While casualisation rids the employer of overheads and wage entitlements of workers in between contracts, externalisation through sub-contracting and use of employment agents pushes workers beyond easy unionisation.

The Maritime and Dockworkers' Union (MDU) organises the ashore employees of the maritime industry. Economic reforms resulted in the ceding of the activities of the state owned enterprise, the Ghana Ports and Harbours Authority (GPHA) to private companies. The intention is to reduce the role of state owned GPHA to that of a landlord with the sole task of rent collection from companies using the services of the port. The major activities at the ports, stevedoring and cleaning, were privatised and a workforce of 3,000 declared redundant. Stevedoring workers operate in gangs of 16 to load or off-load cargo and clean ships that dock at the two main ports of Ghana. In order not to lose its members, the MDU together with five other stevedoring companies set up the GDLC as an employment agency, to hire the affected workers. This arrangement allowed the union to retain its members but produces conflict of interest. Workers of the GDLC are engaged on non-permanent basis as casuals and paid weekly peace rates. Their conditions of work are highly precarious, with low, irregular earnings, dependent on the availability of work. Even though MDU is the major share holder, holding 20\% of enterprise shares, it does not have the required majority on the company board to effectively defend its members. MDU in this instance serves as an employer with concerns for productivity and workers' conduct. The defence of workers' right to decent income and working conditions has taken a back seat. The conflict of interest is also compounded by the fact that the on-site management of GDLC are members of MDU. They are however, permanent workers. Permanent workers have better and more secure conditions of work and do not share a common interest with the non-permanent workers. Here the main informalising pressure is casualisation, as a result of privatisation of a public enterprise. This is complicated by union role as an employer of casual labour.

The GMWU is also faced with work and employment informalisation. The Ghanaian mining sector attracts the highest levels of FDI. GMWU leaders admit that but

\footnotetext{
${ }^{66}$ Interview with CBMWU field officer, November, 2007
} 
for the infusion of FDI, the Ghanaian mining industry would have collapsed. The mainstream mining companies that perform core mining activities have seen improvement in technology and health and safety standards. Union leaders lament though the flip side of the massive infusions of FDI. Foreign employers, they explain, are not interested in developing local economies. Their interest lies with profit. The mines are built as enclaves with little connection to the rest of the Ghanaian economy. The preferred form of post-SAP mining has been open cast with their disastrous environmental consequences for Ghana's rainforests and the surrounding communities (SAPRIN, 2004; Akabzaa, 2001). The factor driving informalisation in the Ghanaian mining industry that challenges unions is corporate restructuring. Mining companies have also resorted to cutting labour costs to increase enterprise profits through out-sourcing and sub-contracting peripheral tasks like the construction of mine physical infrastructure, catering, mineral prospecting and transportation. Non-specialised mining staff are supplied through indirect recruitment by employment agencies. The workplace is characterised by workers with varying relations with the enterprise owner. The system of guest ownership also makes it difficult for unions to engage enterprise owners and enforce negotiated agreements.

The ICU, as explained earlier, organises workers in the industrial, financial, tourism, and manufacturing sectors. Forms of employment informalisation derives from the tendency on the part of large formal manufacturing enterprises to fragment into smaller dispersed units through the usual restructuring, out-sourcing and subcontracting of peripheral activities to smaller companies. Core industrial enterprise safety standards are enhanced with the introduction of improved technologies that boost productivity. But the workforce retained is smaller. The contractors and outsourced companies rely on casual or temporal workers. Banks and manufacturing companies have also adopted the use of contract workers supplied by employment agents. Coca Cola Company for example has seven employment agents supplying workers. The cashiers of Barclays Bank Ghana are supplied through the services of employment agents. The engagement of several employment agents for the supply of contract labour heightens workers vulnerability. Competition among employment agents introduces an element of 'race to bottom' where they are forced to provide labour that is as cheap as possible and less amenable to making claims for improved working conditions.

For GAWU, national leaders explain, formal employment informalisation in agriculture began in the plantations through both externalisation and casualisation, with recourse to smallholder and out-grower schemes as well as the use of casual, seasonal and contract workers. Increasingly plantation expansion has been carried out through the ceding of plantation land to farmers (smallholders) to cultivate. Once company land is exhausted farmers who farm in a certain radius of the company are encouraged to plant crops processed by the company (out-growers). In both cases the company provides inputs and extension support on credit and deducts costs farmers owe through check-off from earnings from the products supplied to the company. 
When smallholders and out-grower schemes become successful the company undertakes to expand by replacing old equipment and increasingly concentrating on crop processing. Labour force is restructured through redundancy where permanent workers are laid off and re-engaged as casuals or indirect hiring through the services of an employment agency. Tasks like harvesting and weed clearing are ceded to non-permanent employees, casuals and seasonal staff. Union leaders talk of a trend of enterprise expansion coupled with redundancy and the engagement of casual labour. Management has been reported by union leaders to be ready to pay high rates to encourage permanent employees to opt for redundancy. In some oil palm plantations full time employees have reduced to less than a quarter of plantation workforce while plantation workforce size has increased by $100 \% .{ }^{67}$

The characteristic features of such informalised employment forms are their precarious nature and the total absence of employment rights and security. Wages come in the form of piece rates sometimes below the national minimum wage of $\mathrm{GH} \$ 2.25$ ( $€ 1=\mathrm{GH} \pitchfork 1.4)$ with cases of envelope wages. Workers have no social security, are not entitled to leave and work for long hours, about 12 hours a day. In some cases the issue of working hours does not come up since they are contract workers and work to a set contract e.g. dockworkers of the GDLC.

Formal employment informalisation extends the production chain, moving workers further away from the enterprise owner who benefits from their labour. The production process is carved out to several workers who, though serving the production needs of one company, occupy different positions within the production chain. By extending the production chain the company can renege on its responsibilities towards workers who serve its production needs. The more informalised the employment type the more diverse the range of workers and distances they are positioned in relation to the enterprises that benefit from the exploitation of their labour. Informalisation of employment dilutes formal employment forms making them less typical. Lengthening the production chain de-concentrates workers by spreading and repositioning them in different forms of aggregation along the elongated production chain. Again the workplace is re-configured and no longer associated with a particular space and a common employer. It is not possible to identify workers by a common employer and space. When spread over a large space in different forms of aggregation, diverse interests develop along the varied distances on the production chain. The situation varies for different categories of workers. Casuals, temporary and seasonal workers as well as small holders in plantation agriculture have a more direct contact with a common employer even though employment concerns might differ. Contract workers however, have more diffused relations with the final beneficiary of their labour. Irrigation farmers have less defined relations with the irriga-

\footnotetext{
${ }^{67}$ Interview with union leaders, March-April, 2008.
} 
tion authorities and even more remote are the final beneficiaries of their productivity.

The impact of informalisation on worker organisation and mobilisation has been debilitating. Worker de-concentration and re-positioning poses organisational difficulties, complicates trade union work. Employment informalisation removes workers from the organising ambit of trade unions, and undermines the principles of trade union organisation based on solidarity and mobilisation. The spirit of solidarity is broken making it difficult to provide a common agenda for mobilising workers who work for the same employer. Organising trade union meetings for example can be frustrating in areas of poor communication and poor transportation and collecting union dues a near impossibility in a system of envelope wages where the check-off system cannot function.

Informalisation of the formal in Ghana rides on two mechanisms: corporate and employment restructuring. In the Ghanaian context, public sector reforms resulting in privatisation and externalisation have been the major precursors (See figure 5.1). Informalising formal economy employment as a result is not limited to the private sector alone. Public enterprises also use casual labour and meet some of their employment needs through contract employees supplied by employment agents. In a similar manner both private and public enterprises have carved out peripheral tasks to medium and small scale enterprises through sub-contracting or out sourcing. The main forms of formal sector informalisation, as captured in figure 5.1, are causing the erosion of formal employment in Ghana and expanding the informal.

It is in the informalisation of work that unions face their biggest organising challenge. Work informalisation now constitutes the new ways in which trade unions are being robbed of their membership and organised labour gains in workers' rights are being eroded. Informalisation serves as a tool for cheapening formal economy labour and unions need to address what form to adopt to deal with the challenges posed by the process of informalisation. Trade unions are constrained by the coverage of labour legislation in Ghana which provides coverage for formal employees in permanent employment. This situation also suggests government's attitude to informal employment and gives the impression that, in the mind of the state, informal employment is not as important as formal. This produces a wrong signal for a nation where $86 \%$ of its working population are placed in the informal economy. The intention of the Labour Act can be called to question and its legitimacy for the Ghana's working people remains doubtful if only a small fraction can call on its protective powers to secure their employment rights. The changing parameters of work and workplace organisation through informalisation call for a redefinition of the margins of workers' rights in ways that connect social concerns with employment conditions. It also calls for a re-conception of collective bargaining. All stages of production call for some measure of bargaining and workers irrespective of where they are placed in the production chain have to undertake various forms of 
bargaining. It is in this way that the workers' movement can begin to engage securing workers irrespective of where they are located.

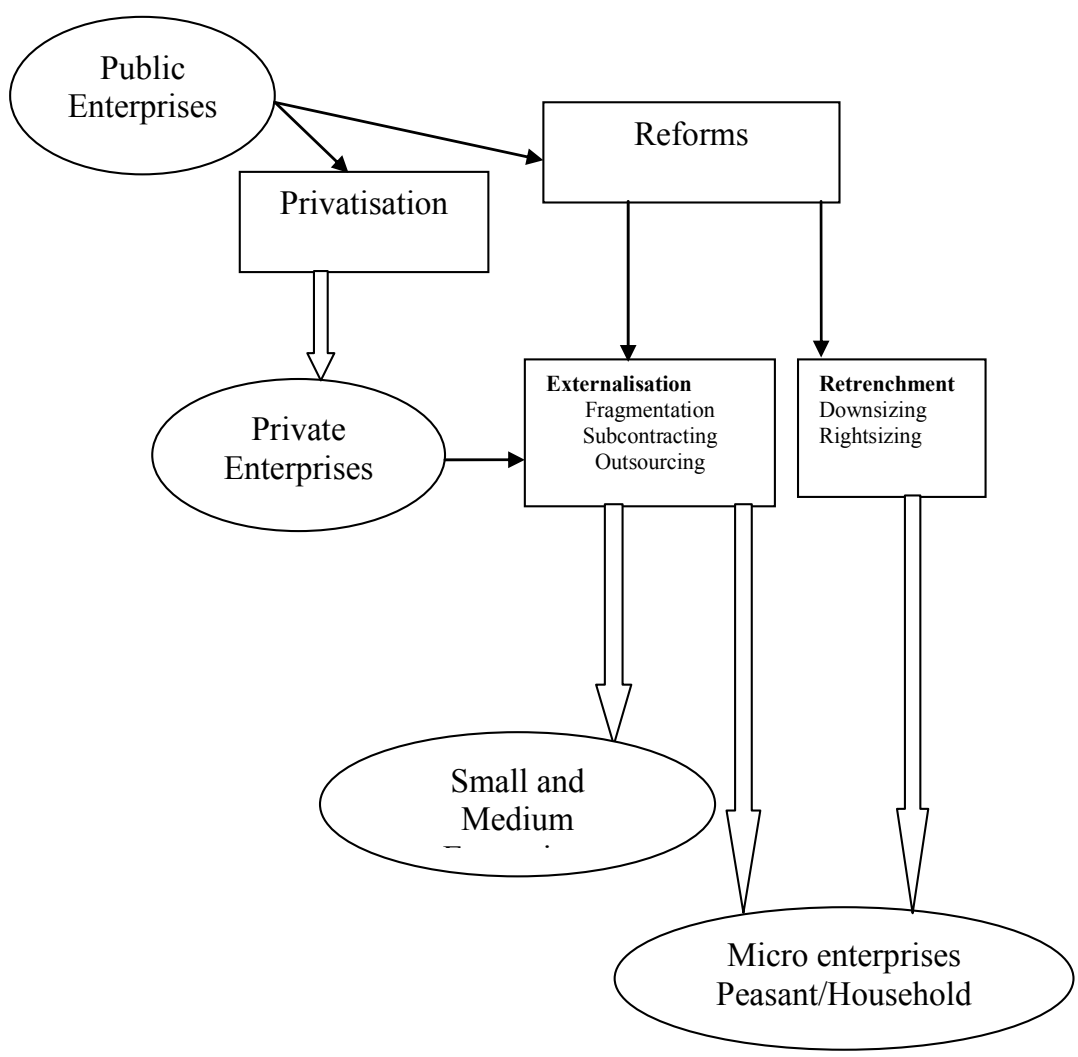

Figure 5.1 Informalising the Formal: Corporate Restructuring

Informal economy based work forms are found mainly in agriculture, services and craft production. Formal economy based enterprises have also taken to the known forms of informalisation outsourcing, sub-contracting, labour casualisation and contract employment. National unions are aware of the implications of this trend for union organisation and workers' rights. The next section examines organisational approaches adopted by trade unions to offer union coverage to informal economy workers and the relative strengths and weaknesses of these approaches.

\subsection{ORGANISATIONAL APPROACHES}

Organising informal economy groups into trade unions have proceeded through a few approaches that either attempt to incorporate informal economy workers into unions through direct individual recruitment or the broadening of union jurisdic- 
tion. Others include affiliating informal economy groups to the union federations or unions working together with independent informal economy groups (Britwum A. O., 2008; Webster, 2005). The nature of the group and levels of intra group organisation within the sub-sector, where informal economy workers are based, determine largely the approaches used. Where group organisation is strong and intra-group regulatory mechanism effective, informal economy associations have themselves initiated trade union affiliation. In Ghana, so far the first two approaches have been the preferred modes for extending unionisation to informal economy based workers. GAWU and TWU to some extent have used the direct recruitment of individual workers to organise informal economy workers. This approach has provided informal economy workers individual membership in the unions. The second approach appears to be the preferred option for the other national unions organising in the informal economy.

GAWU has utilised direct recruitment to organise individual rural self-employed through contracted canvassers who mobilise farmers within the community. Canvassers have additional responsibility to report on the work of the group once organised. GAWU uses service provisioning as organisational entry points and group maintenance tool. These services include training and skills development, precooperative and savings and credit schemes, community afforestation programmes as well as the introduction of agricultural technology. Most of these services have been built around programmes like the Rights to Work, Sustainable Agricultural and Rural Development Programme. The programmes involve trade union education and gender sensitisation, the promotion of child rights and the eventual withdrawal of children as agricultural labourers in the Upper East Region of Ghana. Other services are the Institutional Development and Empowerment and Policy Advocacy and Campaign. GAWU has also used a programme on violence against women and children in nine communities in the Kwaebibirem District of the Eastern Region and income and employment generating activities to organise the rural self-employed. Projects running in 2008 included:

i. Child labour project: mainly in oil palm and cocoa growing as well as fishing communities. The community groups first serve as organisational partners. The idea is to get the community or group comfortable with working with trade unions;

ii. Trade advocacy project: rice campaign project and cotton out growers programmes; this has been in collaboration with Action Aid Ghana;

iii. Health and safety - global pesticide project.

Groups mobilised around such programmes are considered project partners and later organised as trade union members. This is where the canvassers provide support in terms of mobilising and keeping members involved in union activities. 
GPRTU, Traders' Unions of Makola and Madina are affiliated to the GTUC as existing informal economy groups. GPRTU the largest informal economy based national union and the oldest to be affiliated to the GTUC had an effective structure and system in place before seeking trade union affiliation. An internal system for membership recruitment and organisation was in place and functioning before union affiliation. The more recent ones, the Traders' Unions of Makola and Madina, are self organised independent national unions which have direct affiliation with the GTUC. Their structures were developed and established before they were affiliated to the GTUC.

ICU, LGWU and PSWU recruit informal economy workers through existing informal economy groups using the contact person and snowball approach. Affiliation with existing informal economy groups is facilitated through the identification of a key person within an existing informal economy group who is offered training on group mobilisation. The key or contact person is set the task of convincing group members of the benefit of union organisation and persuading the existing informal economy groups to join the union. Once members of an informal economy group agree to join the union a meeting is arranged between union officers, usually the Informal Economy Desk Officers, and group leaders. The first meeting, which involves all group members, discusses the feasibility of trade union affiliation and possible challenges. The meeting is also used to identify group needs and how such needs can be addressed through trade union coverage. It also provides a forum for setting up support structures to address the identified needs. Later group leaders are given training in trade unionism to strengthen group cohesion and internal democracy.

Unions find the contact person and snowball approach convenient for various reasons. First, it facilitates easy access to urban informal economy workers most of whom operate in groups to regulate their trade or set up welfare support. It is cost effective and time saving, allowing unions to organise large numbers of informal economy workers with little funds in a short time with little effort. In a situation where informal economy workers are spread over a large area, working through their established associations saved unions the trouble of having to locate each informal economy worker ${ }^{6}$. The strength of this approach has also been in terms of facilitating easy entry into a group by the union without having to work to secure group confidence. Membership expansion becomes the responsibility of the group. The contact person approach however tends to restrict interaction between union and informal economy members to contact persons alone, a situation which has been exploited by a few contact persons for personal benefit. In one instance (the case of the Aburi Industrial Centre) members were unaware of group affiliation and assumed that the contact person was participating in the activities of TWU in his

\footnotetext{
${ }^{68}$ Interviews with past and present GTUC Informal Economy Desk Officers, October 2007
} 
own right. It took the field work for this study to reveal to the group and officers of TWU that his participation in union activities was not benefiting the group. This event revealed the inherent danger of the contact person approach.

One significant feature of union engagement in the informal economy has been funding. Most of the programmes have been sustained by funding from counterpart European and international trade union partners like the FNV, the ILO, IWF, LO/Norway and LO/Denmark. NGOs like Action Aid Ghana and Business Sector and Advocacy Challenge Fund (BUSAC) have also provided support. The enthusiasm has usually been high with regular union activities during the project cycle, union follow-up and contact with informal economy groups have usually waned on the cessation of project funding. During interview sessions with informal economy groups, leaders made constant, almost nostalgic references to foreign counterparts attached to such funded projects, noting how regular contact with unions were achieved during such periods.

Once organised, unions have to grapple with aligning their structures to include informal economy groups and offer institutional placement for meeting the concerns of informal economy workers. Organisational strategies appear to influence the nature of union membership, for informal economy workers within the various national unions. The specific problems of internal democracy and functioning of informal economy members within union structures form the subject for discussion in the next section.

\subsection{REPRESENTATION IN UNION STRUCTURES}

Union membership can fulfil the aspiration of workers to protect working rights, if it provides avenues for membership participation in union decision-making. Union membership must in addition present individuals as well as identifiable interest groups, procedures for expressing work related concerns and avenues for addressing such concerns. Strategies for membership recruitment appears to underlie the definition of union membership for informal economy members in ways that differentiate them from their formal economy based counterparts within the unions. This challenge for informal economy workers' representation within formal economy based unions and with the union federation has come from how much space within union structures they have gained and how this space has responded to their needs and provided them the occasion to utilise their union membership to address their concerns.

National unions have utilised different arrangements to provide their informal economy members space within union governing structures. Unions such as ICU, GAWU and the TWU, to some extent, remain in the forefront of providing meaningful space within union structures for their members. Informal economy members of GAWU and ICU have been granted equal membership status as formal economy 
workers in the union constitutions. They have representation on the NECs of their unions and at the QDCs as full delegates. They are also eligible to hold union office. They hold the power of vote and can influence union decision-making. Even though no informal economy worker had ever served as a national officer, a few held union offices in regional and district structures of ICU and GAWU. In fact one area dominated by informal economy members within ICU was the Women's Wing. In the Northern Region, members of GHABA held leadership positions in the Regional Women's Wing of ICU. TWU grants delegate status to its informal economy members at its QDC. They do not have any form of representation on other union structures like the NEC that takes day-to-day decisions in between the four-yearly QDCs.

Another area of representation was the interaction of informal economy members with their unions as seen in the forms of activities that they were engaged in. The main union activities that informal economy members cited as being involved in included educational workshops and seminars as well as May Day parades. The Makola and Madina Traders' Unions who at the time of the study in 2007 were associational members of the GTUC, like their counterparts in LGWU and PSWU, were restricted to participation in educational seminars and workshops. Informal economy groups found educational programmes valuable because it helped to promote their businesses. But participation in such programmes, owing to their high costs, was restricted to group leaders and sometimes just key or contact persons. For most informal economy members union membership was reduced to visits by Informal Economy Desk officers or union field officers like the IROs. GAWU and ICU however have been able to expand participation in educational seminars to larger numbers of their informal economy members. This gave union officers better contact with informal economy groups beyond group executives and contact persons.

One factor that undermines informal economy membership status in formal economy based trade unions is the role dues play in the determination of union membership. Finances remain central to union existence for pursuing union goals, supporting activities like trade union education to sustain membership, paying salaries of union officers and maintaining infrastructure for union administration. Union membership size and mobilisation capacity underscore its presence and are important factors giving it credibility and shoring up its political power, but more importantly expanding union financial capacity to maintain members and enhance mobilisation. In fact dwindling union finance is a serious union challenge that membership expansion has been designed to correct. Any mode of dues payment that does not measure up to that subscribed for formal employees is considered inadequate to grant full union membership. Membership status determines the right to attend union meetings and vote at these meetings, it also determines the right to attend the QDC, the right to elect union officers and most importantly the right to hold union office. The size and regularity of dues paid by union members raise issues about 
nature of union membership to grant informal economy workers, whether as affiliates, associational or full members.

Informal economy members of formal economy based unions are constrained by their low and irregular incomes and the manner in which they access their incomes, to pay regular union dues that match up to those paid by their formal economy based counterparts. Low and irregular incomes mean that it is not feasible to demand dues from some self-employed informal economy workers. Where informal economy members are in a position to pay dues, determining levels of dues to collect and modes for collecting them remain a challenge. The other question is whether to collect dues from informal economy workers as individuals or as a group. Most unions have weak dues collection mechanisms anyhow, and are dependent on the check-off system which is convenient for collecting dues from waged employees who earn regular income that is paid through some formalised system. This is absent for most informal economy workers. Most informal economy groups have in place some mechanism for collecting dues and levies to finance their various welfare schemes and it is on this that trade unions have relied for collecting dues. The preferred strategy is for informal economy groups to pay the dues collected on a yearly basis. The study revealed that dues paid ranged from GH\$1.20 for GAWU's rural self-employed to GH\$24.00 a year for Traders groups. Such sums are considered paltry when placed against the 3\% salary deductions formal economy workers pay.

The use of union dues to determine union membership entitlements led to the disaffiliation of the Lotto Receivers' Union from PSWU in 1996. A member of the Lotto Receivers' Union who stood for national union office during the QDC of the PSWU was disqualified on the basis of not being a full union member. Members of the group paid a lump sum and not a percentage of their monthly wages as their formal economy counterparts. The Lotto Receivers objected to the use of size of membership dues for discriminating membership. Dues paid, whatever their worth or value, they insisted, should grant equal membership. Failure to resolve this problem cost the PSWU 5,000 members of an organised and vibrant informal economy group. ${ }^{69}$

Some informal economy groups like members of GHABA and the rural selfemployed groups questioned the need to pay union dues, in the light of the paltry services they received from their national unions. For them, payment of dues should be commensurate with services provided. GHABA members in particular insisted that being self-employed makes them available to participate in union activities like demonstrations and parades. This was in contrast to their formal employment based counterparts who have difficulty obtaining permission from their

\footnotetext{
${ }^{69}$ Interviews with General Secretary of Lotto Receivers' Union and General Secretary of PSWU, 2007
} 
employers to participate in union activities if their absence will impact productivity. For them, time available for union activities is just as important as contributing dues, because union's ability to mobilise its members gives a positive image of its political presence. ${ }^{70}$ The debate as to where to place the balance between availability to participate in union activities against the levels of dues paid to the union remains +unresolved. For unions, however, organising in the informal economy will not provide an avenue to replenish dwindling union dues, it rather strains scarce union resources.

Granting full union membership is a first step towards true union representation. However, there is no guarantee that informal economy members can utilise this space to effectively voice their concerns. The capacity of informal economy members to utilise union structures and processes to further their interests is constrained by the knowledge of their low subscriptions and the nature of their relations with their unions. GAWU and ICU, as mentioned earlier, do not categorise union membership on the basis of size and regularity of dues paid and informal economy members have full union membership status within the two unions. They are eligible to hold union office and can vote on all important union decision-making structures where they have representation. This notwithstanding, leaders of some informal economy groups within ICU and GAWU mentioned that they felt constrained by the level of dues they paid as union members. They explained that the quality of their participation in union decision-making was compromised by the knowledge that they were not paying competitive dues. They were hesitant to make demands on their unions knowing that it would impose high financial obligations. They already felt overwhelmed by the amount of funds that their unions were spending on training activities. In a situation of low and dwindling union finances the reminders of their scant contributions are several. Such reminders produce some element of discomfort and temper their demands on unions.

Institutional anchoring of informal economy groups within the formal based unions was through a unit usually called the 'Informal Economy Desk' and in all cases was located at the union head office in Accra, the national capital. The officer attached to the Informal Economy Desk oversees union activities for its informal economy members. GAWU and ICU which have informal economy members in the regions assign their regional officers oversight responsibility for the informal economy members. This arrangement had implications for the manner in which the concerns of informal economy members were tabled in union structures, in situations where informal economy groups had no official representation. Desk Officers as employees are not members of union decision-making structures, they report to administrative heads who are ex officio members of the NEC. In the GTUC for example the Informal Economy Desk Officer served under the Head of Organisation, who in

\footnotetext{
${ }^{70}$ Interview with informal economy group leaders, December, 2007
} 
addition to a regular schedule of maintaining union consultative structures, was responsible for the Gender and Youth Desks. The head of GTUC's Organisation Department was an ex officio member of the Executive Committee of the GTUC. The concerns of the informal economy members were usually submerged by the heavy load of responsibilities of the Organisation Department.

The more important implication of the institutional location of informal economy groups within union structures is how it underscored union attitude to its informal economy members, by suggesting that they were not full or typical trade union members. It also suggests that trade unions did not consider informal economy workers sufficiently mature to be granted full union membership and allowed to pursue their interest within mainstream union structures like their formal economy counterparts. The institutional location of informal economy groups within union structures acted to limit the ability of unions to represent informal economy members on a continuous and systematic basis.

Informal economy membership in formal economy based trade unions initially impacted internal union dynamism in ways that threatened what formal sector members considered to be their legitimate space in their unions. Because of their numbers as identifiable groups, informal economy workers could easily summon intra group solidarity to turn union power in their favour. This has posed tensions and slowed down the process by some national unions to absorb them into their structures as full members. For PSWU, dues payment becomes a useful alibi to keep at bay informal economy workers' capacity to change union internal dynamism. In ICU and GAWU, granting informal economy workers space within union structures met its own challenges as formal economy based unions protested their inclusion and opposed the idea of sharing union leadership positions. The resentment was presented as the burden of informal economy groups on union finance and the fact that such burdens reduced the ability of the union to deliver meaningful services to those who made the largest contributions. There was also a sense of new entrants crowding out the old and true members of the union. This situation is being addressed by GAWU and ICU which have large informal economy members and increasingly union structures have been opened up through amendments to union constitutions. The other unions however continue to keep the issue at bay.

The next question is the ability of trade union membership to empower informal economy members and offer them the occasion to develop and test their political capacity independent of their national unions. Service provisioning appears to dampen the spirit of informal economy workers to do things for themselves. This is particularly so for the rural self-employed community groups and urban-based informal economy groups who expect union affiliation to provide micro-credit access. The activities of NGOs and the corrupting influence of political parties that have utilised some informal economy groups to further their political interests were serving to undermine union organisational work with informal economy workers. 
Unions have adopted service provisioning by providing occupational inputs like tools, raw materials, skills and entrepreneurial training. The implications of the organisational costs of this method have already been discussed. It is the impact on the ability of informal economy groups to utilise union membership to defend their rights that is of concern here. Unions have resorted to provisioning as an organisational entry tool. GAWU for example mentioned service provision as an important entry and group maintenance tool for informal economy membership mobilisation. However, in the conceptualisation and execution of projects, the point about mobilising groups through service provisioning to defend their rights is lost. The stress is on providing immediate needs and not empowering individual members and group. GAWU's project evaluation documents and reports of regional officers for example reveal that most group meetings were preoccupied with credit access, building infrastructure like day care centres and clinics or providing support to groups to set up or maintain some income generating activity. In fact one GAWU report laments how groups appear incapable of self-help and were dependent on the union to supply their needs (Regional Industrial relations officers' reports, 19971999; end of Project Report, 2003). GAWU's goal for organising rural workers was to provide occasion to address their working rights. The realisation of this goal remains distant as informal economy groups sometimes fail to make the distinction between trade unions and service provisioning NGOs. This situation in itself can demobilise informal economy workers and undermine the whole point of trade union membership.

Union commitment to informal economy workers was sometimes doubtful. The Desks were under resourced, and most unions were dependent on the largesse of their foreign partners to carry out activities for their informal economy members. Again they did not allow the informal economy members to develop their political capacity within the trade unions. The flip side of marginal membership was that union leaders were unaware of the internal dynamics within affiliate informal economy groups.

Despite problems of true representation and lack of meaningful space in union structures, informal economy groups maintained that trade union membership was relevant to their working lives. They cited numerous benefits of union affiliation during interviews. Informal economy groups that initiated affiliation with unions mentioned that their motivation for seeking union membership was to gain protection from harassment from city authorities or secure a mediator to lead their negotiations with formal authorities. In several instances these groups had identified clearly a negotiating partner. Their problem has been the lack of negotiating skills and clout to negotiate to their advantage. For GHABA it was the negotiations of taxes to pay and modalities for collecting the taxes. Members of the Global Handicraft Association and Darkuman Traders' Association joined the LGWU to secure the land on which they were trading. Union affiliation was effective in addressing such concerns while the Global Handicraft Association had secured title to the land 
on which they operated, the Darkuman Traders' Association were able to come to some agreement with sub-metro authorities that protected most of their members against ejection during city beautification exercise that characterised the 2007 and 2008 in the round up to the celebration of the 50th anniversary and the country's independence from colonial rule and the hosting of the continental football match.

The greatest benefit of union affiliation identified by the informal economy groups was their improved image and political clout. The fact of trade union affiliation opens doors to previously inaccessible formal sector institutions like banks and the national social security organisation Social Security and National Insurance Trust (SSNIT). Union affiliation has also facilitated access to formal sector based micro credit and local and imported raw materials for production on credit. Union affiliation strengthened bargaining position with state and local authorities and helped to insulate some groups from harassment and ejection by local government authorities during so-called city beautification or decongestion exercises. Trade union education has also helped to boost group organisation and internal cohesion by providing avenues to arbitration and conflict resolution within the groups. And training has provided skills to for improving economic activities. Union affiliation has helped to enhance production activities by strengthening the rules and adherence to trade regulations that the various informal economy groups had set up. Again various workshops and seminars provided skills for groups like GHABA and the Woodworkers' Association to erect a platform for regulating professional practices, certification and standardizing apprenticeship training. Union affiliation was not only addressing group coherence and internal democracy within informal economy groups, it was in addition, making the connection between strong group structures and enterprise survival. It is in making this connection that informal economy groups remain eager for continued trade union membership despite the challenges outlined.

\subsection{SUMMARY AND CONCLUSION}

Different approaches for organising informal economy workers into unions give varying forms of union membership and this affects levels of representation and space within unions to voice work related concerns. The approach for organising informal economy workers has implications for union's ability to grant meaningful representation and provide space for informal economy members to pursue their concerns within trade unions. The approach also impacted informal economy membership within unions and thereby affecting group identity as well as group independence to utilise union structures to pursue their interests. The discussions so far have shown that the organisational approach has implications for the nature of demands informal economy group members make on union resources, their confidence, group cohesion, identity and independence. These are factors shaping the form of representation that the GTUC and its national unions were offering their 
informal economy members, which in turn impacted their ability to use union structures and processes to voice concerns.

Union shortcoming in their organisation of informal economy members reflects several challenges and some solutions that they attract. The first is union conceptualisation of the informal economy and its relations with the formal. The weakness in granting meaningful representation on union structures and providing equality in institutional anchoring, suggests that unions see the informal and formal economies as separate and unrelated. There is also a disconnection in trade union discourse on informalisation in formal employment and informal economy workers. There is some reluctance on the part of the GTUC and its national unions to engage political discourse on a consistent and systematic basis. These problems account for the choice of strategies that seek to address immediate needs and not structural economic imbalances that impact informal economy work. The choice of union projects to 'service' informal economy members appear to stay clear off challenging the status quo and getting their members to make demands on the state, or local government to address their needs. As a result, the political capacity of informal economy groups remains untapped which capacity expanded would have been to the benefit or trade union strength and relevance and enhanced union political presence. The potential benefit of the successes of GTUC and its national affiliates in organising informal economy workers is being submerged in failure to make the connection that Von Holdt and Webster believe is the solution for true union revitalisation (Von Holdt \& Webster, 2005). This, they place in the ability of trade unions to utilise the energies of core workers based in secure formal economy employment to organise non-core temporary workers and link with informal economy workers at the margins of formal economy.

The fact that various unions have begun to address the question of meaningful representation within union structures suggests some awareness by unions that true representation for informal economy workers in trade unions is important if unions are to benefit from their membership. What remains to unravel is the event that triggers this realisation in unions and the factors that motivate unions to address such issues on a continuous basis. It appears that as informal economy membership increases within national unions their ability to impact change in union structures increases as the case of GAWU and ICU show. Separate and independent organisation gives better representation and voice and the experience of the GPRTU as one of the strong national unions that is consistent and focused on work related problems of its members is a clear example. But GPRTU's success is also dependent on the proportion of informal economy workers within the sector from which it draws its members. It is perhaps in this light that Makola and Madina Traders' Unions have less influence and political presence than the GPRTU. These two traders' union cover only a limited proportion of traders within Ghana. Their political influence will remain within the local governance domain in which they operate. Their 
ability to use the GTUC structures to pursue their interests remains to be seen now that they have full union membership.

Organising informal economy workers responds to union strategies for recomposition to reverse decline and a re-conceptualisation of union function. It has pushed unions to redefine their operating terrain both spatially and conceptually in terms of issues that they pursue as union concerns. The first, in terms of spatial alterations, appears easy to overcome for unions which are actively engaged in organising in the informal economy. The problematic one is unions' understanding of the link between formal and informal work and the process of work restructuring and how work informalisation provides the link between the two seemingly distinct sectors. Organising informal economy workers should provide the opportunity to address union revitalisation within the political and membership dimension and eventually impact their economic power. Union internal democracy has to provide the means for unions to realise this potential. How other strategies combine to shape the internal governing structures of unions will be addressed in chapters that follow. 


\section{Chapter 6}

GENDER DEMOCRACY AND UNION REPRESENTATION IN GHANA 


\title{
6 GENDER DEMOCRACY AND UNION REPRESENTATION IN GHANA
}

\begin{abstract}
Evaluations of both actor and institutional role in union gender democracy strategies generally lament the limited impact while celebrating the increasing number of women who are taking up trade union leadership positions. The consensus however, is that the potential of union gender democracy strategies to transform patriarchal union structures depends on the presence of a critical core of women with sufficient consciousness to take advantage of the space generated. This chapter examines the consciousness of women trade union leaders in the GTUC and selected national affiliates and the potential of their demands and vision to transform union structures. It notes that women's position in union leadership enhances their consciousness, deepens their sense of union ownership and provides them with personal influence. The challenge is how this personal power can be transformed into group power to take advantage of the space offered by union strategies to expand gender democracy.
\end{abstract}

\subsection{INTRODUCTION}

The relations between trade unions and their female members have been the subject of several studies. Early works have examined the complex interrelationship between women and men's positions in the unions and the workplace (Graham, 2001; Deslippe, 2000; Creese, 1999; Creese, 1999; Briskin \& McDermott, 1993; Cook, Lorwin, \& Daniels, 1992). Later studies have shifted from lamenting female underrepresentation and low participation to engage union structures and strategies for addressing gender democracy (Britwum A. O., 2007a; Graham, 2001; McBride, 2001). Some have focused on attempts by unions and women activists to make unions responsive to women's needs (Costello \& Stone, 2001; McBride, 2001; Deslippe, 2000; Curtin, 1999; Hensman, 2002).

Issues around the peculiar nature of women's trade union membership are largely captured under the concept gender democracy. Gender democracy, according to McBride, refers to issues relating to the equality between women and men in union structures. Underlying union democracy are the extent of women's ability to engage with union policy and the adequacy of union provisions for women to voice their concerns (McBride, 2001, p. 26). Writing in the early 1990s, Briskin and McDermott 
deplored the paucity of attempts to examine how union policies and practices systematically discourage women's participation and keep them away from union leadership (Briskin \& McDermott, 1993, p. 330). As unions began instituting strategies to address gender democracy the inability of these strategies to transform the male character of unions to achieve the desired impact has come under scrutiny. So have the conceptual and administrative flaws accounting for the limited success. The general conclusion has been that trade unions, as social institutions, reproduce gender inequalities and require structural and organisational transformation if they are to be more responsive to the gender needs of their members (Britwum A. O., 2007a). This pointed to the need for a better understanding of how power is negotiated within unions and women's engagement in this system of negotiation. It is also unclear how women members utilise this space, what priorities they set and how their concerns as trade unionists and workers create autonomy and power for influencing the content of union gender democracy strategies. What requires unravelling therefore is how existing processes and efforts for challenging male standards and privilege within unions operate (Briskin \& McDermott, 1993).

This chapter examines how women within the GTUC and the six national unions selected (CBMWU, GAWU, GMWU, GPRTU, ICU and MDU) articulate their concerns and utilise union space created through gender democracy strategies for their benefit. Of interest here are the forms of democratic opportunities created for women in representative structures through gender democracy strategies and the ability of women to utilise trade union structures in pursuit of their struggles. Another interest is the identification of the processes which women use to expand their space in their trade unions and how renewal strategies have impacted internal union power dynamics. Information for this chapter is drawn from individual and group interviews with female trade union leaders within the various women's structures of the GTUC and the selected national unions already mentioned. Women trade union leaders were covered in national, regional Women's Committees in the six research regions, namely Ashanti, Central, Eastern, Greater Accra, Northern and Western Regions. Also covered were Gender Desk Officers of the GTUC and the national unions. Others included officers in charge of women's units within the GTUC and the national unions. The information is supplemented by views of national and local union leaders covered in this study and trade union documents. The research was conducted from October, 2007 to June 2008.71

\subsection{UNIONS NEGOTIATING CLASS AND PATRIARCHY}

The problem of female trade union members is revealed first in their low numbers and absence in union hierarchy and activities. Attempts to explain these levels of representation and participation have looked either to women or their trade unions.

\footnotetext{
${ }^{71}$ See Appendix A and B for the details of research participants covered in the study
} 
Culprits identified include the sexual division of labour that assigns women an unequal share of the domestic work, and women's low self esteem (Costello \& Stone, 2001; Cook, Lorwin, \& Daniels, 1992; Grint, 1991; Walton, 1991; Rees, 1990; Ledwith, 2006). Others pointed to problems beyond women's capability. Costello and Stone for example blame female marginalisation in trade unions on the nature of women's labour force participation (2001). Past discrimination provided women unequal access to education and training; and social norms and values underlying gender relations set prejudices that circumscribe women's labour force participation (Cook, Lorwin, \& Daniels, 1992; Costello \& Stone, 2001). Women are either located in jobs outside the traditional union organisational confines or congregate in low ranking jobs that limit their entry into union hierarchy.

Discussions on barriers to women's trade union participation increasingly pay attention to exclusionary practices noting that union work reinforces a male culture and segregates women into stereotypical union positions (Ledwith, 2006; Briskin, 2006; Briskin \& McDermott, 1993). Others have noted how unions, like all other social institutions, reproduce and reinforce existing inequalities (Ledwith, 2009; Britwum A. O., 2007a; Sayce, Greene, \& Ackers, 2006; Hensman, 2002; McBride, 2001). Union organisation is based on the principles of solidarity and mobilisation for the defence of workers' collective interests. This assumes membership homogeneity with a shared social and work experience (Curtin, 1999). Within these principles unions are expected to subsume the differences that mediate the workplace experiences for various categories of workers (Harrod \& O'Brien, 2002; Creese, 1999). Creese, explaining the contradictory relations inherent in the solidarity principle that obscures other determinants of power and privilege workers bring into their unions, notes that the

complex multivocal nature of working-class experiences is obscured by this characterization of solidarity. On the contrary, class relations never exist in isolation from other determinants of power and privilege. .... Individual experiences are shaped by complex interconnections among class, gender, race, ethnicity, sexuality and so on.' (Creese, 1999, p. 2)

Union membership has always served as a vehicle for defending interests and securing rights. The ability to promote workers' interests or defend their rights presupposes an understanding of the needs of union members. Yet the process of framing claims within representative organisations is selective and at the same time exclusive (Ledwith, 2006; Hensman, 2002; Curtin, 1999). As representative organs unions are a congregation of several groups of workers from varied backgrounds and situations. These backgrounds modify their circumstances providing varying levels of privilege and power that legitimises claims to social resources.

Several reasons have been advanced for union inability to grant their female members meaningful membership. The first is that unions have failed to deal with various forms of inequality that workers bring into their unions (Ledwith, 2006; Hensman, 2002). Hensman, using the experience of India, explains how unions have 
uncritically absorbed existing social stratification into their structures and processes. The inability of unions to deal with forms of inequality that members bring with them into their unions impact how workers are organised and this in turn affects their participation and representation (Hensman, 2002). Women's trade union experience is mediated by class and patriarchy; and trade unions, by assuming a patriarchal character, shape their activities to suit dominant male interests and give male priorities precedence over those of female workers (Ledwith, 2006; Heery \& Fosh, 1990). Unions then become shaped by male needs and masculine ways of doing things (Sayce, Greene, \& Ackers, 2006). Male dominance in trade unions is supported by a fixation on union rules and procedures which produce forms of exclusionary practices that are supported by male resistance and closure (Ledwith, 2006). For Ledwith, trade union exclusionary practices issue out of a collusion between capital and organised labour and that the final beneficiary is capital (ibid).

The continuous privileging of male members over the female and women's limited access to union structures and processes have raised serious questions about the democracy credentials of trade unions. Termed the gender democracy deficit, there is a general acceptance that women's workplace situation diverges from men's and requires separate targeting. However, the patriarchal norms that pose as obstacles to unions' ability to meet women workers' needs are informed by the conceptualisation of equality, the separation of work from home and social gender relations that permeates the unions. Recognising this shortfall, unions have engaged several efforts to address women's representation and participation. Unions' engagement with gender democracy has been the accumulation of efforts of feminists and trade union activists leading an agenda for women's rights globally and within unions. The leadership role assumed by the UN for women workers has been the responsibility of the specialised organ, the ILO, which has utilised conventions and recommendations to guide union efforts. In response, several activities have been developed to address union gender inequality. Evolving strategies to deal with gender democracy has forced unions to reconceptualise equality to embrace difference. For Briskin and McDermott, it is only in this way that union structures, processes and patterns of decision-making that promote male privilege can be placed under scrutiny (Briskin \& McDermott, 1993).

\subsection{DEALING WITH GENDER DEMOCRACY}

Instituting gender democracy strategies implies an acceptance by unions that membership inequality is incompatible with core union principles. The numerous initiatives evolved by unions to address gender democracy, when grouped according to their relationship to mainstream trade union structures, generates two main approaches. Figure 6.1 below is a representation of the various union gender strategies. There are those that provide women independent space to pursue their workplace and trade union gender concerns as a disadvantaged group, and those that offer special conditions to improve individual women's participation in union deci- 
sion-making and activities (Koch-Baumgarten, 2002; McBride, 2001). Separate organisation promotes women's membership autonomy and independence from mainstream union structures and activities, while special provision for representation provides women inroads into mainstream union structures (Healy \& Kirton, 2000; Briskin \& McDermott, 1993). Women's autonomous bodies in trade unions variously termed women's divisions, self-organisation or separate organs, exist as independent organs operating at local, branch, through regional to national levels (Figure 6.1). In addition, unions promote independent events or activities like conferences, seminars that target only women (Ledwith, 2006; Costello \& Stone, 2001; Cook, Lorwin, \& Daniels, 1992).

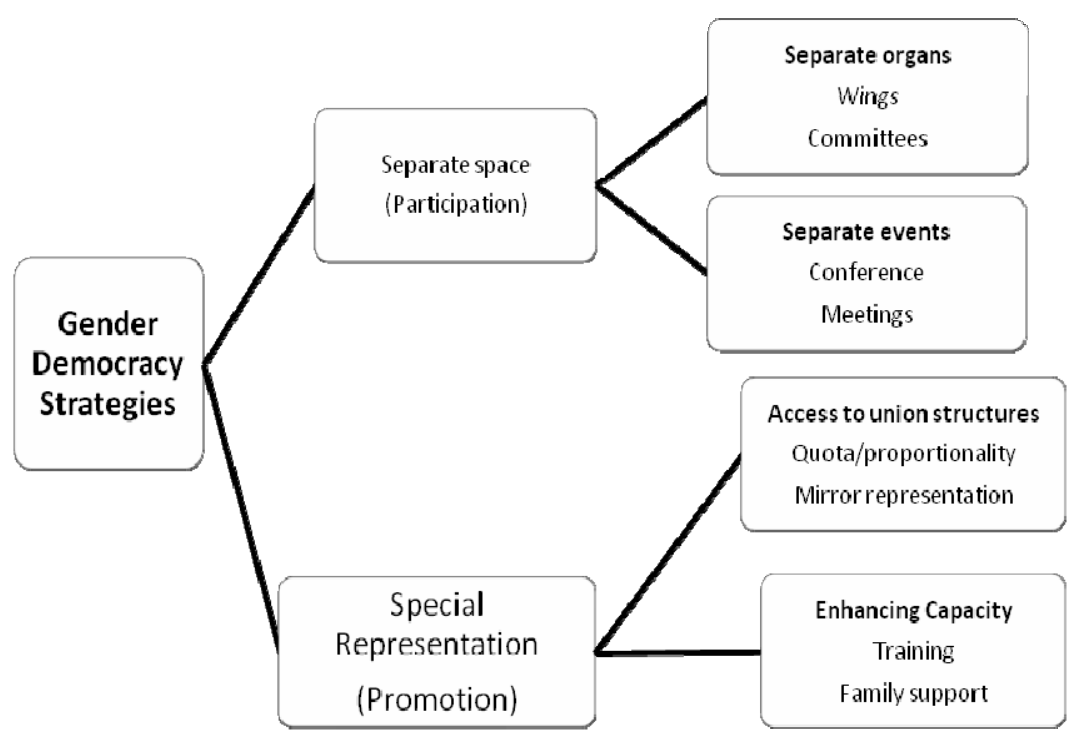

Figure 6.1 Union Gender Strategies

The second set of strategies is geared towards increasing women's representation in trade union structures and building their capacity to participate in union activities (See figure 6.1). These include set quotas or proportionality where unions make a conscious effort to ensure that women's presence in union activities is proportional to their membership. Women's representation in union activities is improved through reserved seats, official or staff appointments or their placement in visible union positions (Briskin, 2006; Costello \& Stone, 2001; Curtin, 1999; Cook, Lorwin, \& Daniels, 1992). Rights of representation can also take the form of structured opportunities where union activities are oriented to create greater opportunity for women with family responsibilities to attend union functions. This is done by adjusting the time for union functions or providing childcare support. Strategies here focus on women as individuals. 
Deslippe, notes that one problem that has stood in the way of women's trade union participation has been their capacity. Women's ability to influence union decisionmaking goes beyond their physical presence and quoracy (2000). It depends on factors like their ability to be vocal, and control over union rules (Deslippe, 2000). Gender democracy strategies target such shortcomings through structured opportunities, in the form of education and training activities aimed at providing women trade unionists skills and knowledge. Others are geared towards providing women support through networks and mentors. Trade union education has been instrumental in building women's confidence and enhancing their capacity to hold trade union office and engage union structures.

The process of devising strategies has its pitfalls and several factors have been identified as mediating the ability of unions to devise and implement effective strategies for addressing union gender democracy deficit. Union ideology, existing forms of power relations, patriarchal norms as well as union and membership capacity are important factors which shape strategy success. Union ideology shapes the conceptualisation of gender strategies and direct attention to what is perceived as the cause of women's marginalisation in the trade union (Koch-Baumgarten, 2002). According to Rees (1990) and Walton (1991), gender democracy strategies are effective to the extent that they target the problem of power, and exclusively male control of union power. Increased participation does not necessarily translate into power, neither do well resourced women's organs without connection to mainstream union structures (Mc Bride, 2001). These writers rather point to an inherent danger in strategies that focus on women to shift attention away from union structures and lay the blame on women's attitude or lack of capacity (McBride, 2001; Walton, 1991; Rees, 1990). Strategies that provide women representation on mainstream structures also generate concerns that orienting union activities to respond to women's family roles leads to a tacit support for the status quo. Far from providing an opportunity to question gender power relations that allocates women an unequal share of household responsibility, women's work burden is increased (Costello \& Stone, 2001; Rees, 1990).

There is in addition the question of how much power is allocated persons who are assigned responsibility for devising gender democracy strategies (Ledwith, 2006). The power of the prime movers of gender democracy strategies is important to offset the inevitable resistance and backlash that emerge as traditional power holders feel threatened by what they consider to be an encroachment on their assumed stronghold in unions (Ledwith, 2006). Koch-Baumgarten (2002) offers indicators for assessing the power assigned women's representatives. They include the effectiveness and broad based nature of the power, ability to make public statements beyond the unions and the availability of an independent avenue for voicing demands. To be effective the authority of women's organs must move beyond mere tokenism. They must have authority to intervene and not consigned to advisory position. Union power for women's representatives is enhanced if they can fill positions external to unions and have the right to object, suspend, or veto union decisions they con- 
sider inimical to women's gender interests or influence decisions that affect women's gender interests positively. The power of women's representatives is improved through their inclusion in caucusing and the adequate access to union education and information (Koch-Baumgarten, 2002).

The use of women only structures as an accepted institutional practice for tackling gender democracy involves changes to union rules, alterations in the processes and structures of political representation usually backed by promise of adequate funding (Ledwith, 2009; McBride, 2001). However, discussions on the potential impact of women's self-organisation and separate events to challenge male norms are mixed. Women's organs have been hailed for offering women space to develop voice, legitimacy, visibility and invent strategies for promoting their interests within their unions (Ledwith, 2009; McBride, 2001). Autonomous or self-organisation, as a source of trade union education and networking, fosters women's leadership skills. As an empowering space it serves as a spring board for carrying the 'gender agenda from the margins into mainstream union' (Ledwith, 2006, p. 109). Self-organisation offers women a source of group power which they can use to undermine male norms underpinning trade unions (McBride, 2001). Others have however had the occasion to question its gender transformational potential and ability to expand women's space and amplify their voice in unions (Cook et al, 1992). In most instances separate organs have little power to take forward women's concerns. They remain isolated, without links to formal union power sites and decision-makers are not obliged to take account of the policies they generate (Cook, Lorwin, \& Daniels, 1992).

The positioning of women's separate organs in relation to mainstream union structures has been of central concern in discussions on the effectiveness of gender democracy strategies. Though separate organs offer women union members opportunities to participate in union activities in meaningful ways, this does not automatically translate into greater voice or representation, a major concern for union internal democracy. Briskin \& McDermott, (1993) as well as Cook et al (1992) observe that the success of separate organising depends on women's location within the union structures, the levels of decision-making powers accorded, union resources at their disposal and the level of autonomy they command in union structures. Separate organs are effective only to the extent that a delicate balance between autonomy from the union structures and integration into these structures can be achieved (Briskin, 2006). Integration provides access to union resources and promotes legitimacy. Where there is too little integration, separate organs have been marginalised. Too much integration has succeeded in blunting the transformative potential of women's autonomous organising (Ledwith, 2006). While autonomy has been achieved, in many instances it is the weak integration into union structures that has limited the transfer of energies generated in separate spaces into representative structures. The connection with mainstream union structures ensures that women's concerns are not limited to women organs but are made part of the larger union 
agenda (Cook, Lorwin, \& Daniels, 1992; Briskin \& McDermott, 1993). In fact Deslippe notes that gender strategies can be counterproductive. If increased female participation and representation does not equalise gender relations, male power in trade unions can be further enhanced (2000).

Several reasons have been identified as accounting for women's structures remaining on the fringes. Not least is the question of power sites within trade unions that women's organs threaten. Women's collective action can undermine notions of union solidarity and question the male norms that underpin trade unions: the full time male worker with no family obligations (Creese, 1999; Curtin, 1999). Ledwith blames union exclusivity and sectionalism that derive from collusion between capital and organised male labour for the limited success of women's autonomous organising (Ledwith, 2006). Curtin uses the notion of contingent solidarity to explain how various power blocs are able to mediate union structures for their interests (1999). The determination of union concerns involves a selective process of inclusion and exclusion that calls for the formation of different micro solidarity sites within the unions. Contingent solidarity explains how groups within unions, especially minority groups, can bring up their interests or lose out in some situations. For in so far as dominant groups find that it is in their interest to bond up with others to push their agenda, the disadvantaged have an opening for putting their interests on union agenda. Framing claims therefore becomes a fluid process that minority groups like women trade union members can benefit from in situations where their concerns conflate with those of dominant union groups. But in most instances women lose out because their interests and those of dominant male trade union leaders do not cohere. Women's separate organs have been blocked on the grounds that they contradict union's notion of equality based on sameness (Cook, Lorwin, \& Daniels, 1992).

Women representation on mainstream union structures as an effective vehicle for addressing union gender democracy raises its own contradictions. Discussions on gender democracy devote attention to who qualifies to represent women and the procedure for determining women's real concerns. In several instances, problems have been raised in connection with the qualification of women to act as representatives of women and the notion of a universal set of issues that can pass as women's interests (Costello \& Stone, 2001; McBride, 2001; Deslippe, 2000; Curtin, 1999). Though there is agreement that the very nature of representation rests on identity and articulation of needs, representation is as important as what is being represented. Discussions on women's representation are not to disqualify women from representing other women but to point attention to the problems that women trade union representatives face. Separate organs for women and promotional representation on mainstream union structures demand that women appeal to their identity as women. Two requirements for effective representation lie in the ability of the representative to represent the views and interest of the represented and assume their characteristics (McBride, 2001; Curtin, 1999). Over the question of who qualifies best 
to represent women's interests, the choice has been to identify women for the reason that representation involves the formulation of identities and interests. Since women's needs are still in the process of articulation, separating who does the representation from what is being represented poses difficulty (Deslippe, 2000; Curtin, 1999).

As discussed earlier the very notion of an absolute quality of women with a shared experience of gender and class exploitation is strongly contested by women's experience in the trade unions (Ledwith, 2006; Hensman, 2002; Koch-Baumgarten, 2002). Women do not constitute a homogeneous group with a fixed set of objective interests. As workers, their interests are neither fixed nor universal but vary over different working spaces and particular points in time (Hensman, 2002; KochBaumgarten, 2002; Curtin, 1999). Women's interests are derived from an intersection of their gendered positions with varied sources of power like their class, occupational status, race, caste and ethnicity. Pursuing women's interests in trade unions therefore demands attention both to the method by which interests are constituted and the process of representation.

The links that individual women representatives have with women's separate organs and the obligation on their part to pursue women's concerns are two related issues that arise out of the debate on women as representatives. These are particularly controversial issues in situations where such women are elected by a mixed group and not a women-only constituency (McBride, 2001). Women representatives face the additional hurdle of linking women's interests to mainstream union concerns, otherwise they run the risk of relegating their presence on union structures to mere tokenism.

Not only is women's qualification to represent women problematic, the manner in which they become union activists or assume union leadership has been noted to differ. Ledwith explains that the reasons for women being favourable to their trade unions (triggers to activism) come from two directions: workplace protection and support should they have work related problems, as well as family influence for trade union involvement (Ledwith, 2009). Examining women trade union leadership trajectories Ledwith et al isolate sponsorship from above or encouragement from below as major events that push women into union hierarchy (Ledwith, Colgan, Joyce, \& Hayes, 1990). Women's union activism is usually preceded by some triggers that bring women's leadership potential to the attention of union leaders, usually male leaders who then sponsor such women into union positions (Ledwith, 2009; Ledwith, Colgan, Joyce, \& Hayes, 1990).

The general conclusion is that the effectiveness of gender democracy strategies is dependent on union ability to recognise factors constraining women's trade union participation and representation based on accurate information on women's workplace and trade union concerns. This will call for a rethink of the manner in which 
unions relate to women's workplace participation as union concerns, structures in place for women to voice their concerns as well as avenues provided women representatives and separate organs to influence union decisions within mainstream union structures (Costello and Stone, 2001; McBride, 2001). It is in this light that McBride's suggestion to address how group representation or participatory democracy feeds into representative democracy becomes imperative, for it underscores the need to examine determinants of outcomes of union strategies (2001).

Several suggestions have been offered for addressing the questions of women's participatory democracy and evolving a set of concerns that are representative of women trade union members. These include, bridge-building between women's organs and women trade union representatives and staff as well as mechanisms for aggregating women's concerns and reaching out to communities and social groupings beyond trade unions (Ledwith, 2009; Sayce, Greene, \& Ackers, 2006; Hensman, 2002; Koch-Baumgarten, 2002; McBride, 2001). For Ledwith, a vibrant core of female activists and intellectuals are important ingredients for generating consciousness that allows for transforming union structures (2009). To address these questions, there is the need for bridge-building between women's organs and women union representatives, and women union staff and evolving mechanisms for aggregating the multiplicity of women's concerns (2001). At the grand level, women trade union organs and members need to reach out to community and social groupings beyond trade unions for a better attention to gender based inequalities that pervade the general society (Ledwith, 2006; McBride, 2001; Deslippe, 2000). This strategy, involving women's groups working collaboratively across societies on key agendas, is described by Ledwith as 'rainbow politics' (Ledwith, 2006). The question is how unions can achieve such connections and how union gender democracy can be expanded to embrace all such multifaceted issues. These are real problems that union gender democracy has to confront if strategies are to succeed in addressing power inequality within unions and not limited to making women more like men so they can fit into existing union structures that otherwise exclude them.

\subsection{EXAMINING UNION GENDER DEMOCRACY}

Evaluation of union gender democracy usually focuses on how male dominance is maintained despite strategies to address women's power imbalance (Ledwith, 2009; Koch-Baumgarten, 2002; Costello \& Stone, 2001; McBride, 2001; Deslippe, 2000; Creese, 1999; Curtin, 1999). Recently some interests in the limits to gender democracy strategies in terms of their comparative strengths and weaknesses have been explored (Ledwith, 2009; Sayce, Greene, \& Ackers, 2006; Koch-Baumgarten, 2002). These studies have noted the presence of male power, diversity in female trade union membership and female consciousness as influencing the potential of union gender democracy strategies to alter patriarchal practices. Any examination of the implications of gender democracy strategies on union internal dynamism will as a result have to take on board issues of power relations, and female consciousness. 
Behrens et al's power dimension assumes some common membership interest that is pursued by unions. But as noted in earlier discussions, unions are not composed of a homogeneous membership, and their internal dynamics are determined by the dominant group. Embedded in unions is a system of power relations that leads the labour movement to support the status quo through the ordering of union structures and operations to serve male interest. Female marginalisation in trade unions has altered as the institution of gender democracy strategies have triggered quantitative increases in the number of women trade union leaders. However, how such quantitative expansion of women in union leadership translate into efforts on the part of women to alter trade union structures for the pursuit of their interests remains a challenging issue in union gender democracy that requires further interrogation. This calls for a framework that focuses on the kinds of spaces created through gender democracy for women trade union members and leaders and how they use this space. Such a framework should be able to discern issues of class that give working people their common identity, and gender power relations that set women's experiences apart from their male counterparts within the workplace and their trade unions. The different social backgrounds that women bring to the workplace mediate their class and gendered experience in the workplace and their trade unions.

McBride's use of Bachrach and Baratz's typology of power to explain how union power is maintained through the mobilisation bias and rules of the game to organise women's concerns out of union agenda or neutralise women's ability to challenge male norms and reduce inequality has been instrumental in explaining how union male dominance is maintained. Curtin's notion of contingent solidarities that pushes the debate from what she describes as the 'politics of gender' to the 'politics of difference' helps to account for how differences among women can block gender democracy strategies (Curtin, 1999). McBride has provided useful tools for understanding the female/male union dynamics. Curtin draws attention to the various forms of social and class positioning among women as a social category and how such factors mediate access to their unions and forms of contestation that can emerge from gender democracy. Ledwith, (2009) uses Gramsci's dynamic of hegemonic class relations to suggest that the formation of counter-hegemony and transformation is the means for securing forms of inclusive democracy against the traditional masculinised union hegemony. Her concern is the key ways in which dominant hegemony can be destabilised and a counter gender democratic hegemony established. Ledwith's framework offers opportunities to explore how women are utilising trade union space and the conditions under which women trade union members can transform trade union structures and processes. It also offers useful analytical tools for identifying how disadvantaged groups derive sufficient consciousness to destabilize dominant ideologies. Beyond the inter and intra gendered dynamism likely to be produced from gender democracy strategies, it is necessary to have the tools for exploring the internal dynamics among women trade union 
members and how they organise their space provided by gender democracy strategies (2001).

There is need for a framework that shifts attention from women as passive agents under the manipulation of union patriarchal norms to identify sites of women's agency within the spaces that union gender democracy strategies have offered. This demanded an examination of how strategies impact women's consciousness and allow them to frame their demands in ways that challenge the male norms that underpin trade unionism. Behrens et al's (2004a) dimension of union power resources was altered to incorporate a class analysis and borrowing from McBride's (2001) notion of redistribution of power to oppressed groups in representative institutions as proposed by (Figure 6.2).

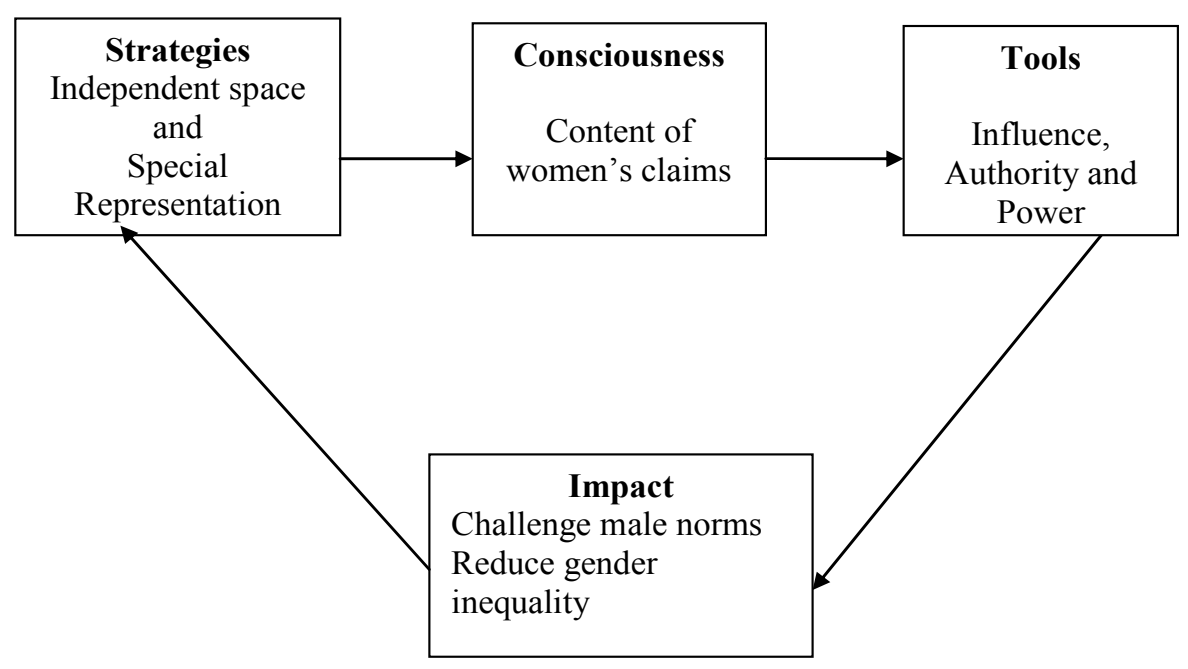

Figure 6.2 The direction of union gender democracy strategies

By expanding space for female participation and representation, trade unions provide women space to undermine structures and practices that support male dominance. Women's consciousness provides the framework within which they frame their claims and utilise existing strategies to pursue their claims (see Figure 6.2 above). The outcome of women's pursuit will be the acquisition of tools like power, authority and influence that they can rely on to generate additional demands to utilise strategies to their benefit. Framing and pursuing claims will lead to further empowering of women only to the extent that they are able to gain authority, influence or power within unions (figure 6.2 above). Each gain in power and authority enhances consciousness and plays directly to challenge male norms while at the same time refines women's demands on their unions pushing for alterations in gender democracy strategies. 
We turn to examine how the GTUC's gender democracy strategies have proceeded and the specific manner in which women trade unionists have utilised the space provided them. Earlier accounts on GTUC have noted the inability of gender democracy strategies to achieve set goals and how GTUC and its national unions remain male dominated. Female representation has improved over the years. However, the GTUC and its national unions remain male dominated. There has been little account of how women union leaders are faring and how their unions have responded to their increased representation (Britwum A. O., 2007a; Britwum A. O., 2000; Graham, 2001). Equally unclear is how women's interests are framed and what forms of solidarity they have utilised to support their claims within their unions. The next section explores the kinds of spaces and nature of participation the different forms of strategies adopted open up for women.

\subsection{THE FEMALE FACTOR IN THE GTUC 72}

Two peculiar features of trade union membership profile in Ghana are the heavy formal economy representation and male dominance. These features are in sharp contrast to labour force participation trends in Ghana with a predominant informal economy employment that captures over $85 \%$ of Ghanaian working women. The proportion of the Ghanaian labour force located in the formal economy is $12 \%$ female and 23\% male (Ghana Statistical Service, 2002). Women constitute an estimated $25 \%$ of GTUC membership and hold $12 \%$ of union decision-making positions (TUC (Ghana), 2001). Representation of women in decision-making structures within the national unions varies from zero, in male-dominated unions like the Railway Enginemen's Union, National Union of Seamen and the GPRTU, to a high of $31 \%$ for public sector based unions like TEWU.

Factors isolated as accounting for low female representation and participation in the GTUC include the male character of the GTUC, attitudes and perceptions about women's capacities, sexual harassment, women's domestic responsibilities and their lack of access to trade union education (Britwum \& Martens, 2008; Britwum A. O., 2007a; Graham, 2001). Low female participation in trade unions is no indication of their lesser need for trade union protection. On the contrary, the disparities in working conditions and experiences in the Ghanaian workplace create greater need for women to be protected by their labour movements (Britwum, 2007a). Women congregate in occupational categories where labour protection is lowest. They have unequal access to work benefits, and they earn lower wages (Duncan, 2004; African Labour Research Network, 2004; Ofei-Aboagye, 2001; TUC, 1997). Their unequal

\footnotetext{
72 This section is based on Britwum and Martens, 2008. The Challenge of Globalization, Labor Market Restructuring and Union Democracy in Ghana, Britwum, 2007a The Gender of Trade Union Democratic Participation, 2007a and Chapter 4 of Britwum, 2007b The Ghana Trades Union Congress: Sixty Years of Promoting Workers' Rights.
} 
workplace status, compounded by their gendered social positions, creates additional labour concerns.

The GTUC began concerted efforts in 1969 to address female participation and representation in the confederation and national unions. The efforts started with the establishment of a coordinating organ, the Women's Unit within its administrative wing. They were intensified in late 1987 when the national unions, like GAWU, ICU and GMWU, instituted actions to address women issues within their ranks by establishing separate organs for women. GAWU was the first national union to give constitutional backing to its efforts to secure legitimacy. The women's unit of the GTUC was upgraded to a women's Desk in 1992, expanding its operations from three to seven of the ten regions of Ghana. The CBMWU gave constitutional backing to its women's organ in the same year. It was not till 1996 however that the GTUC had its first woman representative on the Executive Board (EB). As a Deputy Head of Department, she served on the EB as an ex oficio member without a vote. In the same year, the GTUC adopted its first gender policy to guide its work with its women members, and the Women's Desk was transformed into the Gender Desk. By 1999, Women's Committees from the local, through the districts and regions to the national levels were already in place and eleven national unions had set up their corresponding women's organs. These included case study unions like GAWU, GMWU and ICU as well as others like GTPCWU. In 2003, the GTUC had the occasion to celebrate its first woman as chairperson of a national union, the PSWU. This was an elected position open to both sexes. In 2008 she contested the position of GTUC's national chairperson and lost by a slim margin. Even though she lost the elections, standing for such high union office was seen as a significant improvement in women's participation in the GTUC.

The activities of the special administrative organ, the Women's Desk, which coordinates women's activities within the GTUC and the national unions, are spelt out in a gender policy which is reviewed every four years for consideration and adoption by the QDC, the highest decision-making body of the GTUC. The policy, which has seen three revisions since it was first tabled in 1996, sets the framework for addressing union gender democracy. Policy objectives have in the main been directed at improving gender awareness in the unions, building women's capacity through separate activities or increased access to mainstream trade union education. The policy, in addition, proposes constitutional amendments and directs attention to the elimination of gender discriminatory workplace and legislative provisions. Policymaking therefore constitutes an important process for setting out the framework that outlines GTUC's gender democracy strategies and maps out broad objectives that guide the work of national unions.

GTUC's strategies for addressing gender democracy captured in figure 6.3 below are similar to those summarised in figure 6.1 above. The two-pronged approach of 
separate organs and promotional strategies is employed here. Separate organisation presented in GTUC takes the form of Women's Committees that provide women members the occasion to participate in union activities as well as special activities and programmes that offer women the occasion to build capacity to take up leadership roles in the unions (Figure 6.3). Special representation or promotional strategies come in the form of quotas and reserved seats. The GTUC and all national unions have a second vice-chairperson position reserved for women only. The GTUC and its affiliates, operate a quota policy which calls for at least 30\% female participation in all their educational and training programs (See Figure 6.3).

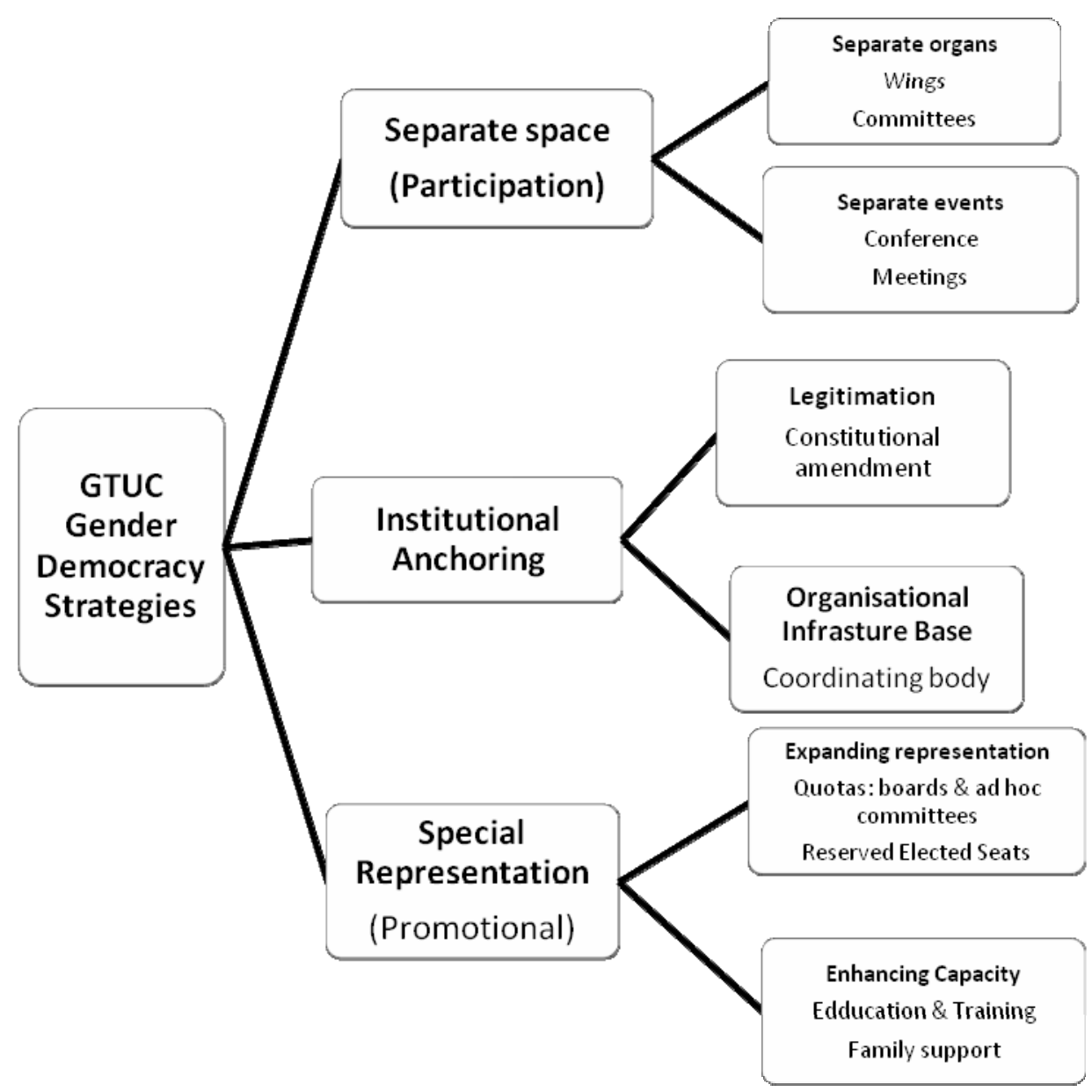

Figure 6.3 Profile of GTUC's Gender Democracy Strategies

The women's self-organs operate in tandem with the consultative structures at the regional and district levels, the RCLs and DCLs. The women's wings and commit- 
tees have a constitutional mandate to pass on their concerns and decisions to the DCLs and RCLs for action. Decisions of the National Women's Committee are supposed to feed into deliberations of the Executive Board. These separate female trade union organs have provided a main conduit for several female trade unionists to access union decision-making structures (Britwum \& Martens, 2008; Britwum A. O., 2007a). They have also served as a channel for females to take up elected positions in mainstream union structures. There has been some improvement in terms of an increase in the number of females ready to hold union office; and female presence in union decision-making has enlarged considerably. Female representation on the EB of the GTUC for example increased from a low of 5.6\% in 1996 to 16\% in 2003 (Britwum, 2007b). The potential of women only organs is however constrained by financial allocation to the Gender Desk as well as a policy conceptualisation that focuses on women avoids tackling gendered relations within the structures of the GTUC (Britwum, 2007a). The linkages between women's organs, women representatives and mainstream union structures also remain weak. The opportunity for women representatives to impact decision-making in union structures are limited by their lack of voting power (Britwum, 2007b). These findings do not deviate from situations elaborated earlier by other studies on trade unions elsewhere.

GTUC's union gender democracy strategies have evolved from top-down strategies and not in response to demands from women trade union members for an enlarged space and voice in their trade unions. There are signs, however, that women are beginning to respond to the opportunities provided by presenting themselves for elective positions in ways that were unknown in the late 1960s when the women's section was first set up. The rest of this chapter explores the stories of women trade union leaders and members.

\subsection{WOMEN'S ENGAGEMENT WITH GENDER DEMOCRACY IN THE GTUC}

External support has played an important role for introducing gender democracy and increasing the gender awareness within the GTUC and its national affiliates. Most trade union gender activities were initiated with support from international labour organisations like the ILO, and other trade union solidarity partners like the International Federation of Plantation, Agricultural and Allied Workers (IFPAAW), FNV and the LO/FTF-Denmark ${ }^{73}$. Unions like GAWU, ICU and GMWU have benefitted immensely from direct external support. The others have relied on GTUC funded programmes to develop the potential of their female members. Female union leaders in GAWU report of their involvement in union gender democracy strategies as early as 1983/4. The international project funded by IFPAAW provided the occasion for GAWU to engage with its female members. The strategy which involved the creation of separate events was initially directed at providing women

\footnotetext{
${ }^{73}$ Interviews with Gender Desk officers of the GTUC (past and present) and GAWU October 2007
} 
workers with alternative employment skills. Later activities included training in leadership skills and time management. Female union leaders interviewed explained that time management training was very important for coping with the heavy time burdens of women trade unionists. GAWU appears to be a leader in terms of taking up membership issues beyond the traditional male formal economy worker. GAWU's coverage of agricultural workers brings it into contact with other forms of workers. GAWU as a pioneer in gender democracy is closely followed, in a chronological order, by ICU which began strategies to address gender democracy in the early 1990s. The MDU and the GPRTU are considered late starters. Till the GTUC's policy guidelines came into being, they had nothing in place and did not appear to have any intention of forming women's organs or getting women to hold union political office. The GMWU and CBMWU were midway starters. Like GAWU, the GMWU also benefited from foreign affiliation initiatives that resulted in the setting up of its Gender Desk that was well resourced to implement a series of activities geared towards giving women skills to boost their confidence and encourage them to stand for union office.

External support meant that male union leadership was not provided the occasion to consciously reject the introduction of gender democracy strategies. This has its advantage in terms of facilitating the adoption of gender democracy strategies without much opposition from male leaders. The problem though is the political orientation of the activities that are adopted and the sustainability after project funding has lapsed. For GAWU, the 10-year IFPAAW programme helped to introduce gender democracy strategies and allowed several women to discover their unions in ways that would not have been possible. But sustaining the activities after the project has run out has been a challenge. GAWU has been unable to maintain its ten regional women's representatives recruited to run its gender projects. Only three remained at post at the time of the study and one was already on her way to retirement ${ }^{74}$. Another shortfall was the absence of a vibrant core of feminist activists within unions who could lay claim to the evolution and policing of gender democracy strategies.

Opportunities to be involved in union educational programmes constituted the major access for women to engage their unions in ways that drew out their leadership potentials and to gain a better insight into union activities. Several women leaders interviewed revealed that before their close interaction with their unions, they considered trade union work a male responsibility and that the union was made up of the local union leadership. Trade union women leaders interviewed identified two avenues as having propelled them into union office: chance encounters with male union leaders, and active participation in separate activities for women. Chance encounters cited included asking male union leaders to explain

\footnotetext{
${ }^{74}$ Interview with GAWU Gender Desk Officer, November, 2007
} 
monthly union deductions or seeking union support to access work benefit. Others were performing seemingly ordinary tasks like delivering a vote of thanks at union functions or asking questions during union meetings. One chairperson of the regional women's committee explained:

I started work as a casual worker in 1993. I was chosen to attend the Delegates Conference because the General Secretary wanted gender balance. The woman supposed to give the vote of thanks at the delegates conference did not turn up so I was invited to step in. My intervention must have impressed the national officers because I was offered a permanent union position as staff in October 1993. I became interested in trade union activities and found a role model. I stood for elections later as Second Trustee and won. I was later elected First Trustee and held that position till 2003 when I was elected as the Chairperson of the Regional Women Committee. ${ }^{75}$

Such events were cited in several instances during interview sessions as the occasion that propelled very active trade union women leaders into union activities. First they enabled women to be 'discovered' and secondly facilitated women's access to union activities especially trade union education. By providing such women opportunities for understanding their unions through access to union education they gained knowledge, skills and motivation to aspire to union office.

Most women leaders interviewed entered union leadership at the local level usually as women's representative. This position, they explained, granted further access to union education and interaction with their unions in ways that provided even more skills and helped gain further confidence and respect for their unions. It is clear that women require some stimulus to generate their interest and enhance their capacity to be involved in union work. This finding strongly corroborates Ledwith as well as Ledwith et al's findings about triggers and sponsorship being important in the way women become union activists or leaders (Ledwith, 2009; Ledwith, Colgan, Joyce, \& Hayes, 1990). While the occasion to be involved in union activities (triggers) generates their interest in their unions by exposing to them to the utility and relevance of their unions, union educational programmes, they insist, provide confidence building platforms and motivation to aspire to higher union office. Trade union education also helped to expose women to their working and trade union rights. Another critical stimulus was the impact of women trade union leaders in urging them on. Each woman trade union leader mentioned the support of an older trade union leader that provided them the required motivation and confidence to keep exerting in office. Names mentioned included women organisers like Dorcas Amo and the first head of the women's desk Veronica Coffie. Some also gained this support from their male leadership and IROs, local union executives were among those cited. Male leadership therefore is not the only one in a position to offer sponsorship from above. Female leaders were playing this role as well.

\footnotetext{
${ }^{75}$ Interview with ICU Regional Women Committee Ashanti Region
} 
National unions however varied in terms of the occasion they provided their women members to discover their unions. ICU appears to be providing women greater occasion for self-discovery, while the GPRTU provides the least. The female members of the GPRTU are mainly union staff or women who trade at the vehicle loading points called lorry stations. The entire field work experience produced one female who derived union membership as a vehicle owner. Attempts to contact two other female vehicle owner members were however unsuccessful since one was too ill to grant an interview and the other had returned to her hometown in the Volta Region having lost the use of her vehicle. Female GPRTU members who were staff had less access to union education provided by the GTUC and there was little attempt by their national union, the GPRTU, to fill the void and grant its female members separate space to operate or access to union education: two key activities that propel women into union leadership positions. For the CBMWU, the Ghana Highways Authority provides most of its female members. Being a public sector based organisation the Ghana Highways Authority employs a substantial number of women in its secretarial section, something that does not occur in the private construction enterprises that now dominate the Ghanaian economy. The MDU also derives most of its female members from the public state enterprise, the Ghana Harbours and Ports Authority. Female members of CBMWU and MDU had some level of encounter with their unions that was better than female members of the GPRTU.

\subsection{BARRIERS TO WOMEN'S TRADE UNION PARTICIPATION}

Field findings revealed that the same old barriers continue to hinder female trade union participation. Constraining factors cited by women trade union leaders included male resistance and hostility. Apathy to trade union activities, women's capacity and lack of supporting networks as well as under resourced women's organs were additional barriers cited. Apathy to union activities originated from women's sense of union utility and knowledge about their unions. Women trade union leaders complained about the levels of ignorance that existed among women workers about trade unions and perception that trade union is a male activity. This was related to women's low encounters with trade unions, the dearth of occasions to interact with their unions. The avenues for interacting with unions were few. Most of the time unions were seen as leaders and there was constant reference to union leaders as 'the union people'. As a result 'women leaders carry a heavier load in unions; females have to live by example all the time because females have domestic responsibilities that men do not have'. ${ }^{76}$

Women's sense of ownership of their unions was lower than men's and the distance between union and their members appeared longer for women than for men judg-

\footnotetext{
${ }^{76}$ Interview with Women union executives, Ga West, November, 2007
} 
ing from the number of times they participated in union functions. This low union presence in women worker's lives was derived from their ignorance about unions and at the same time the low presence further heightened their ignorance producing a vicious circle. The level of awareness and distance between union and female membership varied according to unions, status within the union hierarchy and length of operation as a union leader. Female leaders of the CBMWU who were located in the private construction industry appeared to have the lowest level of understanding of union structures and had no idea where to channel their workplace concerns. In one region the female union leaders of the CBMWU displayed ignorance of their rights and uncertainty of the demands they could make of their unions. Understanding of union structures was affected by the length of time one had held a leadership position in the unions and the level of union hierarchy in which one was located. There appeared to be some relationship between knowledge of unions and knowledge of the labour law. The quality of engagement in union activities increased with rising levels of union hierarchy. Gender Desk officers, female national union executives displayed higher knowledge of their unions.

The main access to trade union education was through one's position as union leader and this was facilitated by the practice of organising trade union education for elected leaders. Access to union knowledge available to those outside union leadership was low. In addition, union meetings provided avenues for members to interact with their unions in ways that promoted greater awareness of union functions. Most rank-and-file women members whose contact with their unions remained minimal had very little sense of ownership of their unions. The major avenues for members to interact with their unions remained union meetings and trade union education. Women's participation in such events however remained low.

Women's separate events were important sources since their organisation tried to minimise participation barriers like childcare responsibilities. Most unions made provision for childcare support at their seminars and workshops. But it appears that the demand on women's time becomes an issue when they have a low perception of the relevance of their unions. In some instances, women leaders complained that attempts to use working hours for union meetings as a way of minimising the demands on women's time with family was not effective. In situations where women's notion of union utility was low, they would rather invest the time off work to take care of domestic chores than attend union meetings. Once women gain an understanding of union functions and realise the benefit of trade union membership, they develop their own coping strategies for managing the demands of home, profession and trade union work. Thus though female union leaders interviewed consistently complained of demands of union work on their time, they reported with pride efforts made to cope. So it is a question of what women believe they gain from their participation in trade unions that makes them interested in trade union activities and ready to make sacrifices to make up for the demands on their time. This is however not to underscore the enormous demands that the triple burden of domestic 
work, occupational engagements and trade union work impose on women. This corroborates Walton's findings that union involvement for women is enhanced by their sense of the rewards that participation brings (1991).

Most women trade union members happen to be in low ranking job positions and easily become target for victimisation if their actions court management's displeasure. There were therefore reports of dismissals, transfers and blocked promotions that were attributed to women's involvement in trade union activities that management found displeasing. This threat was shared by male trade union leaders as well. Where it was possible to access management on such accusations the usual response has been negligence of duty. Management insist that union leaders use union work as a cover to neglect their duties and for personal gain. Union leaders maintain that it is their right to use working hours for union work. The issue of how much of working time can be devoted to union work remains at the discretion of the unions and their employers. They seldom agree on a unified standard. So it remains a whip that management can use to get rid of union leaders. Some female union leaders however reported that once bosses feel that their enterprises stand to benefit from their workers' participation in union activities, they readily release workers for union meetings. On the whole though employers and management believe that workers are the final beneficiaries of trade union events and they should make the necessary adjustment to personal schedules outside work hours to attend union activities. This observation is important to the extent that the workers and employers interests do not always cohere.

The gap between women and their unions affects their acquisition of leadership skills and ability to overcome gendered inhibitions about their capacity to hold leadership positions. The problem, trade union female leaders explain, is compounded by the near absence of female trade union leaders in the locals. The few women who become leaders are easily isolated since avenues for interacting with other females are limited. At the workplace, female junior staff trade union leaders do not get the benefit of senior staff tutelage because of the perception that senior staff should not be members of trade unions. 'Female Senior Staff reject unions; they do not like getting involved in union activities. They feel they are okay' ${ }^{77}$ The Labour Act, 651 is usually cited to justify the exclusion of senior staff from trade union membership. Promotion to senior ranks has caused unions to lose members. Again women's committees have often come into conflict with more welfare oriented Ladies' Associations that have evolved in some workplaces. This was a peculiar case for members of the CBMWU. Women's low level of education also affected their trade union knowledge. Their inability to read stood as a barrier to written union information and trade union education which was usually fashioned for English speaking and reading members.

\footnotetext{
77 Interview with CBMWU ER Regional Women's Committee, March 2008
} 
Women trade union leaders complained of male hostility which they attributed to male dominance and resistance. Male dominance in all workplaces coupled with their lower status meant that women operated from an inferior position in their various workplaces. Their ability to confront male dominance was muted because of their numbers. In addition female leaders complained of a general lack of awareness among males. Notable were the male dominated unions of the GMWU, GPRTU and CBMWU. As some women union leaders explained:

\begin{abstract}
The union is hostile towards women who want to stand for office. They only have one image of women and tend to sexualise their female colleagues. Male members are more interested in wage issues and so trivialise women's workplace concerns and believe that women's workplace concerns are not union issues. For example, the perception is that provident fund is a union issue and maternity leave is not. Men don't understand women's issues because of their social consciousness, they are not gender sensitive. They are amazed that women should stand for union office and there are few role models to challenge this notion. There is a mental block that is difficult to penetrate even at gender sensitisation workshops. ${ }^{78}$
\end{abstract}

The general reaction to male dominance was mixed. While some felt it was a matter for women to handle through a change in attitude others were less indulgent and asked for a more concerted action to deal with male resistance. Women's union background appeared to affect their reaction to male hostility or dominance. Female leaders in GMWU and CBMWU quickly run behind the excuse that it was in the nature of the work of mine and construction to create domineering men. There were quick references or outbursts like 'it is the nature of the work' 'you know the construction industry' 'what else can you expect from people who spend so much time with such heavy machines?' or 'you have to understand and accept men as men; it all depends on one's ability to tolerate these men'. ${ }^{79}$ Women leaders especially those located within the GTUC's Regional Women's Wings had a different opinion and were very critical of what they explained were male attempts to manipulate the women's wing. Males they explained were

...holding women on a thither always, holding women on a rope and pulling them with them. They should leave all things concerning women to women and should only guide. Males should not be the key players manipulating women leaders and dictating who should be elected for union positions they should give the modalities ${ }^{80}$.

One result of male dominance was the manner in which women's concerns were received by their unions. There was the general accusation that men tended to trivialise issues women raised within their unions. Male hostility and resistance also take the form of sexual harassment and most female union leaders complained of varying degrees of sexual harassment. They included, in terms of regularity of occurrence, name calling and branding, heckling and defamatory gossip and sexual

\footnotetext{
${ }^{78}$ Interview with GMWU Gender Desk Officer, December, 2007

${ }^{79}$ Interview with union leaders, February to June, 2008

${ }^{80}$ Interview with female union leaders, February-June, 2009
} 
advances. Some women leaders attribute this to low levels of social consciousness among male counterparts who cannot envision relations with females beyond sex. Such men, they insist, sexualise all encounters with female colleagues. While some asked for sexual harassment policies within the trade unions most had devised coping strategies to deal with these impediments. Coping strategies involved making changes in women's behaviour which they believed were at the source of sexual harassment, by trying to behave as men or modifying the manner in which they dressed. In some spaces, trade union women leaders were leading demands for mandatory use of workplace uniforms in the belief that uniforms will eliminate what is considered 'provocative dressing' and check incidence of sexual harassment. One high ranking female leader explained that men feel more comfortable accepting women when they act like them. The flip side of this was the introduction of sexual corruption and bribery and there were accusations of trading sexual favours for access to union educational opportunities. The study was however unable to verify such accusations. The fact of the case was not its prevalence, but the perception among female leaders that such levels of negotiations take place, has implications for female progression to high union office. Women leaders faced forms of exclusionary practices and these events point out how within the GTUC, union concerns remain 'constructed and built around men's needs' (Sayce, Greene, \& Ackers, 2006, p. 402).

Female union leaders explained that getting elected into union office posed enormous demands but equally challenging was their relationship with female members of their unions. Their problem stemmed from the lack of institutional arrangements to facilitate a discourse among women trade union leaders within mainstream union structures. The distance between female union members and their unions was also a setback. Female union leaders have noted that one strategy they have to adopt in order to get accepted by their male colleagues has been to act more as men and less as women. Walton describes the pressure on women leaders to act as men in order to be accepted as the power of conformity (1991). In this particular instance the power of conformity was re-orienting women away from their female constituencies in male organs. In their bid to become accepted, they lose the one support that they require and also deny women true representation on union structures. This leads to some sense of isolation on the part of women leaders and undermines the motivational or inspirational role that female leaders are expected to play for union members. While women leaders feel isolated the female members have difficulty identifying with women union leaders. The general feeling among female trade union members in the locals was that women who hold union leadership positions are not their leaders. This was particularly the feeling towards women second vice chairpersons of the national unions. In fact, women trade union members did not feel that the position of second vice chairperson could be used to secure any gains for their interests in their national unions. 
Gender desk officers were also another group of females in the union hierarchy who were isolated. As union staff, they owe little allegiance to the female trade union members even though their work brings them into contact with female members and they somehow serve as a link between the women's organs and the union structures. Their location in national headquarters of the unions isolated them further and the dwindling resources that stifle activities of the desk meant little contact existed between them and the members. Gender Desk officers tend to serve as some unofficial representatives of women in the trade unions on international forums. This was a sore point for Women Committee leaders in the regions. Aware of the importance of international exposure for building capacity and enhancing confidence, women committee members cited this as an anomaly that had to be addressed. They insisted that opportunities for international travels should be reserved for 'real union members' and not union staff.

Union structures that constrained interaction between women trade union members, leaders and staff, also distanced leaders located within the national structures from members. There was no sense of identification of female members with the leaders. In fact, there was more recognition of male leaders as leaders than women leaders as leaders. Female union leaders, in addition to their concerns about isolation, harboured fears of a break in succession. The fall-out of low investments in union gender democracy strategies, they insisted, was the disappearance of a core of women trade union members ready and equipped to assume union leadership role. Women leaders felt that male resistance to female trade union leaders was less difficult to confront than female resistance. They however made a distinction, that while male resistance was the result of male ego, female resistance emerged from their limited understanding of trade unions and what unions stand for.

One of the major factors that support male achievement in trade unions has been the absence of demands of housework on their time. In short men achieve as union leaders because they have no responsibility for housework. Female responsibility for housework frees men for work outside the home. In exploring women trade union leaders' coping strategies, one consistent response was the supporting role of their mothers, especially in the area of childcare and baby minding. These leaders in effect could be said to have their own 'wives', and like the men, they had to rely on women to take up their domestic responsibility. Women in all instances played a key role in supporting the work of trade union leaders even when the leaders were women. Trade union reliance on women's gender roles for the effective functioning demands further examination. Husbands' attitude to women's work, where women leaders were married was also important in the lives of these women trade union leaders. In one instance, the national leader and her husband were all active trade unionists. Women leaders confirmed the observation that home and family support were important elements in the lives of women trade union leaders (Ledwith, 2009). What is striking here is the role of women especially mothers in the lives of women 
trade union leaders. Trade unions are active beneficiaries of women's unpaid domestic labour whether the leaders are females or males.

Of the several barriers to the work of female trade union leaders discussed one of the major culprits highlighted was apathy on the part of female union members. Most women, respondents insisted, do not see the benefit of trade unions in their working lives. They generally do not identify with their unions and have a low sense of union ownership. Others attributed women's seeming apathy to their general disinterest in things around them. Some also believed that women's apathy can be located in the thinking that they do not see why women's condition should change. For some however it is the demands on women's time that leave them little time for trade union activities. Women on the whole, they explained, were linked up with too many organs and societies that compete for their time. It will appear that women are occupied in groups and societies that they find rewarding or whose utility they perceive as being relevant to their lives. It will be interesting to investigate women's extra domestic and workplace activities and what benefits women derive from involving themselves in such groups. The demands on women's time for their engagement in union activities become an issue in situations where they have a negative perception of union utility. Though women's domestic burden and the attitudes of their husbands were noted as barriers that stand in women's way such barriers get compounded when the investment of time in union activities is seen as unrewarding and the immediate benefits are not clear. The problem then shifts from women and their attitude to unions to become the ability of unions to reach their female members. This becomes a potential site that women trade union leaders will have to engage in their effort to push for an expansion in gender democracy strategies.

\subsection{THE WOMEN'S COMMITTEES AND RESERVED SEATS}

The 1990s were very active times for union gender activities and most women leaders lament the inactivity of unions in organising separate events for their women members during the 2000s. The investments in women's capacity building created a pool of women trade union leaders ready to take up union work and stand for elected positions. All the women leaders interviewed mentioned how union education had played a key role in boosting their ability to stand for union office and the opportunities union gender programmes have offered them to develop their potential. Most women trade union leaders found participation in mainstream union structures the best avenue for accessing union decision-making structures even though separate events and organs were the space in which they first cut their political teeth.

At the time of data gathering very few women's committees were functional and operating in a consistent manner that was engaging women union leaders and offering them avenues to challenge union structures. The height of support for the 
promotion of gender equality spanned the late 1980s through to the mid 1990s. In the 2000s donor support had dwindled amid calls for gender mainstreaming. Gender democracy strategies in the area of separate organs and events receive only lip service within most national unions. The emphasis has shifted more to promotional measures creating greater avenues for female participation in mainstream union activities, like special seats and expansion of quotas in union activities. The potential of promotional measures have not been in doubt and all unions have reserved seats for women on all decision-making structures, right from local to branch, district, regional and national bodies. In addition, all ad hoc union boards are bound by quota representation. This has the effect of getting more women involved in union activities and still furthering their ties with their trade unions. Thus individual women had avenues to union activities through the strict adherence to quota representation.

The separate space is less effective in offering women members the opportunities to get close to their unions, a failing that was blamed on financial constraints. Union inability to support their women's organs financially was blamed on two factors: low union subscription and lack of political will. While the male leadership insists that but for dwindling union resources their women's organs would have been more active than is the case, women leaders believe that the problem lies in union priorities and male leadership's attitude to unions' gender democracy strategies. Female leaders insist that low subscriptions should translate into low funding, not complete absence of financial allocation. Whatever little is available should be managed to cover all union activities. Since other union activities still run, albeit on a reduced scale, a little funding, no matter its size, could have allowed female organs to maintain some level of activities and managed to provide female trade union members some platform to develop skills and interact with their unions. Complaints about funding for women's activities were highest among regional GTUC Women's Committee leaders and among national officers of GAWU, MDU, and CBMWU. Women's Committee members of the GPRTU did not name any period of intense activity and did not harbour any nostalgic memories of past good times. Female trade union leaders within ICU however blame dwindling support for women's activities on the union leadership struggle which had stalled the functioning of union structures. There was the belief that legal battles were sapping not only ICU finances but distracting the attention of leaders from important union matters including gender democracy.

Access to funding was therefore a big issue for the functioning of women's organs in the trade unions. The problem was blamed mainly on union dwindling finances and lack of political will on the part of trade union leadership to ensure some minimal regular allocation of whatever little union resources was available. Funding was a problem not because it was unavailable but more because of the manner in which union events is conceived; and poor communication infrastructure that beset the country as a whole. Union meetings are expensive because of the need to pay for 
venues, in addition to travelling and feeding costs of attendees. Poor communication network hikes up costs, meeting notices sometimes have to be distributed by hand. Written notices are important for members to secure release from their workplaces. Most regional offices have no facilities for producing letters. Few had computers and fewer still had printers. One relied on a typewriter. None had photocopying facilities and had to use commercial sources for reproducing their meeting notices. The cost of organising union events as a result was quite high.

Women trade union leaders expressed frustration at their lack of power to influence the allocation of union funds and at unions' inability or reluctance to commit funds for the operation of the women's organs. They were equally frustrated by the limits on regional and district initiatives to raise funds outside the ambit of national union supervision. Female union leaders in the regions bemoaned the strict rules of the GTUC that barred independent fund raising at the local level. Some such initiatives that had been thwarted by this provision were cited. For some women leaders 'the functions of the women's committee are only on paper, they have become mirrors that we only look $\mathrm{at}^{\prime}{ }^{81}$.

Another major complaint about the functioning of the women's organs was the institutional location of Women's Committees within union structures. As noted in the works reviewed above, the institutional location of women's separate organs determines its potential to challenge male norms and open up union space for greater female representation. Women leaders interviewed underlined this fact. Female leader interviewed complained about the general ambiguity of relations between the Women's Committees and mainstream trade union structures especially the lack of connection with the EB of the GTUC and the NEC of the national unions. Again there were complaints about trade union bureaucracy and the hierarchical way in which union decision-making structures operate, moving it out of women's control. The laid down procedures are for decisions to emerge from the districts through to the regions and finally to the national level. Such procedures had a way of filtering out women's voices, removing from their leaders the power to influence the nature of women's concerns that unions addressed. National leaders in ICU were particularly concerned about the lack of structures in the NEC to receive women's specific complaints even though women's representatives held positions on this important union decision-making body. In other instances, women leaders explained that there was some ambiguity about who represent women within mainstream union structures like the NEC of national unions or the EC of the GTUC.

Contrary to Ledwith's (2006) observation, promotional representation featured as the major union strategy for promoting union gender democracy. This is one strategy that was operating in full force and had the support of all unions. The process

\footnotetext{
${ }^{81}$ Interview sessions with female trade union leaders, June 2008.
} 
of creating a special seat for women at all levels of the union decision- making structures was instrumental in getting women into union decision-making. Women who held such positions observed that getting into union decision-making constituted a journey in self-discovery and an awakening of individual ability. It had also provided them the opportunity to access mainstream union office and to prove to male sceptics that females are capable of holding union office effectively. There were however some misgivings about its effectiveness. As some women leaders explained, since the goal of union gender democracy strategies was to bring women up to rub shoulders with men, they would have wished for strategies that promoted women to aspire to mainstream union office like that of the Secretary-General, and not to special seats. For them, the present provisions in GTUC and national union constitutions that reserved the second vice-chairpersons' position for women appears to say that women are not ready for top union positions and were only good for middle level positions. Others felt that promotional strategies could affect women's confidence. In addition, it created the perception among some male union leaders that all other positions were for males and women only had access to the reserved seats. In one region, some women leaders reported male surprise and displeasure with women who stood for mainstream union positions stating that they were trying to take away male positions.

The achievements of the special seats and quota representation appear to be strong at the individual level. However, the occasion for women representatives to relate to the general female membership and other women's organs was weak. Women leaders did not have automatic membership on the Women's Committees. One female leader holding mainstream trade union leadership position in her national union recounted her embarrassment when she was walked out of a National Women's Committee meeting on grounds that she had no constitutional mandate to participate in the meeting. Relations between the Gender Desk and the Women's Committees in the GTUC and the national unions were also unclear. It was not clear who should initiate activities, and to whom such activities should be submitted to for approval. As an administrative organ, the Gender Desk by right should come under the authority of the Women's Committee. But because it initiates programmes directly from mainstream organs, it denies women's representatives in union organs and Women Committee members access to making direct inputs. Lower level women's organs have no authority to initiate their own activities without reference to the Gender Desk. Even though the GTUC's Gender Desk is expected to coordinate the work of the Gender Desks located within the national unions, there is no constitutional mandate supporting this provision. Some women leaders believe that the absence of clarity of mandates and linkages is deliberate to cripple the women's organs and render them incapable for addressing women's workplace and trade union concerns. Increasingly they questioned union leadership commitment to gen- 
der democracy. Their conclusion was that the 'Women's/Gender Desks functioned more as face saving gimmick for unions' 82 .

Earlier in the chapter, it was noted that gender democracy strategies tended to be undermined by the lack of connection between women's separate organs, and mainstream structures. Field findings show that beyond the autonomy/integration balance is how women leaders connect with women trade union members. The institutional isolation of women leaders from their members and the women's organs means that they have no constituency support to rely on to build power and wield authority to influence union decision-making in the interest of women members. This situation raises questions about their credibility among female members in whose interest they have been granted access to union political office. In the absence of a support base and low levels of union education, one issue that came up in interviews with women trade union leaders was some sense of isolation and recourse to other sources of engagement for strength to survive in union structures. Because low union resources were affecting levels of capacity building for union officers, they tended to look beyond the unions for a repertoire of skills. There were constant references to leadership skills acquired in religious organisations and NGO forums as providing the capacity for organising other women and for surviving as leaders in trade unions. The gender based NGOs provided women union leaders alternative sources of gender education and assistance to develop their leadership skills and acquire the needed capacity and confidence to stand for union office. While in union office however women leaders, especially at the local level, insisted that religious practices provided support and ideas for handling workplace and trade union challenges. This sense of isolation was especially evident in the first batch of women office holders who had no one to learn from and had to find their way in uncharted terrain amid hostility from males and older women who felt uncomfortable with younger women challenging traditional norms. The first woman on the GTUC's Executive board notes that it was 'hectic because there was no woman around, no one to learn from and no one to consult'. ${ }^{83}$ But this sense of isolation was tempered for most women leaders who mentioned the presence of some older woman union leader in providing support and motivation. But in all, most women were emphatic about the impact of older women office holders in their lives.

When the question was raised as to who should first organise women, women trade union members believe that responsibility rested with the unions, especially the GTUC, to first bring women together and then provide resources for women to subsequently maintain active membership of the organisation. Women union leaders were convinced that the union structures provided the space for women to de-

\footnotetext{
${ }^{82}$ Interview with present gender desk officer, February 2008

${ }^{83}$ Interview with former GTUC gender desk officer February 2008
} 
velop the required awareness and pick up the necessary leadership skills to place themselves in union positions to engage union structures. Separate events were very important in drawing them out and granting them the confidence to operate within the union structures. The fact that more and more women were ready to take up leadership positions, it was pointed out, was the result of the union educational activities. There was the fear that the crop of women who benefited from union education might and are offering themselves for union leadership positions might disappear in the face of reduction in union education for women. Promotional strategies have a potential to offer women union leaders some space for influence and open up some possibilities to develop power to challenge male norms, as female presence on union structures increase and women are no longer forced to behave like men. This potential, as explained, can be realised if women trade union leaders acquire the needed consciousness that makes it possible to identify the patriarchal structures that constrain their participation and representation.

\subsection{CONSCIOUSNESS AND THE CONTENT OF WOMEN'S CLAIMS}

This section examines the impact of gender strategies on women's consciousness and their ability to utilise the space offered however limited to alter male power within the GTUC and the national unions. The level of consciousness was discerned in three areas: first their demands on their unions, and secondly, the nature of goals or vision which motivated women leaders within their various locations in the union structures. A third area was whether women union leaders placed the cause of women's low participation and representation, in women's capacity and attitude or within the union structures. Such issues were considered important for providing women leaders some indication of their own sources of power and directing attention to possible solutions. Ledwith notes that social creativity, social change and collective action are important for achieving transformative agenda in trade unions. These processes are contingent on consciousness at individual and group level for women to develop collective action through 'micro-mobilisation' (Ledwith, 2006). Women's consciousness is discerned by whether they questioned union structures from a traditional trade union mindedness or feminist perspective (Ledwith, Colgan, Joyce, \& Hayes, 1990). There was in addition interest in the extent to which their demands challenged traditional female gender roles and called for gender role transformation.

Two main types of women's demands on their unions were discerned. There was the type that targeted women as individuals and the type that was directed at union structures. Demands targeting women were directed at securing more capacity for their engagement in trade union structures or fulfil their gender roles. Some of the demands that targeted women's work in the trade unions sought to address women's need for trade union education (Table 6.1). 
All respondents present at the group interviews attested to the impact of union education in enhancing their capacity to engage in trade union activities. For most women, it was thanks to trade union education that their interests in their unions were awakened. Women leaders based their demand for trade union education on the fact that women in the trade unions generally had a lower educational background and virtually no other source of union education. Again they believed that trade union education for women was empowering and would get women to understand the structure and function of their unions and improve on their sense of union ownership. As one respondent put it 'union 'education has changed us, we longer see our union as a welfare association' 84 . The benefit of trade union education for women, they insisted, was that it helped to enhance women's knowledge, deal with ignorance create awareness and give women confidence and capacity to speak in public. They considered these important ingredients in the making of women trade union leaders.

Table 6.1: Women's Leaders Demands on their Trade Unions

\begin{tabular}{|l|l|}
\hline Target of demands & Content of demands \\
\hline Women's work in the trade unions & - Trade union education \\
& - Leadership commitment \\
& - Leadership skills \\
\hline Women's domestic responsibilities & - Skills development \\
& - Income generation \\
& - Family Life Education and Marital Counselling \\
& - Women's health and leisure \\
\hline Trade union structures & - Better functioning women's organ \\
& - Support/funds for union activities \\
& - Greater Contact With Gender Desk/national officers \\
& - Broaden space for participation \\
& - Space for women leaders in union structures \\
& - Better operational framework \\
& - Re-conceptualisation of trade unions \\
& - Inter union collaboration \\
& - National union intervention at the local level \\
\hline
\end{tabular}

Source: Field data, 2008

Trade union education, they further explained, was important for broadening the minds of women. The specific content of trade union education that was demanded included introduction to the Labour Act, women's labour rights and responsibilities, collective bargaining agreements, trade union constitution, government policies on wages and salaries, in particular the single spine salary structure (that was under discussion at the time of study), and leadership skills. There was general agreement that women required preparation to take up union leadership positions like mentor-

\footnotetext{
${ }^{84}$ Interview with executives of regional women's committee, April 2008
} 
ing, and acquisition of skills for public speaking for confidence building. It was important also for women leaders to be devoted, selfless and fearless.

The second set of demands targeted women's domestic responsibilities and health issues (Table 6.1). They included calls for unions to provide women workers avenues for picking income generation skills and even capital for developing enterprises to supplement low incomes. This demand was particularly highlighted by women leaders of the CBMWU, ICU and GAWU. The demands were for unions to teach women how to earn extra income to supplement their wages through trading, soap and talcum powder production, food processing and textile dying. Women's incomes they insisted, were lower than men's. Female leaders of GAWU remembered the IFPAW project in the 1980s that provided skills training in baking and other income earning activities for women. Women leaders of CBMWU, mainly those located in the Ghana Highways Authority, insisted that they were the least paid workers in Ghana. As one leader put it, 'we earn monthly salaries yet we are like beggars hopping from one credit scheme to the other' ${ }^{85}$. Demands for boosting women's income earning came up also within the ICU's Women's Committee leaders, especially those in which informal economy members held leadership positions. Here there were, in addition, requests for unions to offer credit management education to enable women who benefited from micro credit schemes derive maximum benefit from such facilities.

Another set of demands targeted women's health and related issues. Requests were made for talks on aging, menopause, cervical and breast cancer, hepatitis B and family planning. Other demands were for cookery lessons, social and leisure activities and charity schemes. Such demands derived from the notion that most women were ignorant about their health and that providing information would help them deal with such health problems better. Of particular importance were demands for talks on menopause. Where women leaders had had the benefit of such talks, they praised their impact on their lives and those of others around them. Others went as far as to demand that women committee meetings offer talks on marital counselling. Some wanted their unions to establish crèches and employment centres for recruiting domestic assistants. By providing women assistance to take care of children and domestic chores they would be able to devote more time to union work, women leaders explained.

Demands for promoting women's participation in trade unions included those that targeted trade union structures for a better framework and support for the Women's Committees to function (Table 6.1). Others involved a re-conceptualisation of trade union activities, stressing the need to broaden the space for the operations of women in the trade union structures or for improvements in the functioning of the

\footnotetext{
${ }^{85}$ Interview with regional women committee Members; February, 2008
} 
women's committees. Demands for improvements in the functioning of the women's committee covered the inclusion of more women members in the activities of the District Councils of Labour (Table 6.1). Some women leaders expressed discomfort at their national unions' attempts to mainstream gender. There were for example concerns about halting the appointment of women organisers. Working as women organisers served as a platform for grooming women leaders. In GAWU and the GTUC women leaders commended the opportunities offered by the position of women organisers to produce women union activists. Others demanded that only women should deal with women's issues and the women's committee be organised as a platform for channelling women's concerns into mainstream trade union structures. There was worry about the GTUC's appointment of general organisers. Women leaders, especially those located in GTUC structures, insisted that women's needs were special and should not be subsumed under general issues.

One demand that was supported by all women leaders as well as female members was funding for the women's committees. Most women leaders were indignant about existing levels of support. They insisted that the GTUC particularly had reneged on its responsibility towards women by failing to provide some special allocation of resources for its women's organs. Other unions that were blamed were GAWU, CBMWU, and GPRTU. In fact, few of the case unions covered received commendation for the financial support to their women's organs. Public sector based unions like HSWU, PSWU and TEWU were mentioned as being most faithful to their Women's Committees and the UNICOF was in the process of revamping its women's organ which was designated as the Women's Commission. Women leaders made demands for financial support for events such as meetings, seminars and workshops. Some went as far as to state that unions allocate specific proportion of its dues $(20 \%)$ to cover the work of the Women's Committees. Others called for a debate on union finances, demanding that the GTUC especially account to women on what percentage of union finances was spent on women's activities within the trade unions. They justified their claims on the grounds that women's committees are the creation of the GTUC and it behoves it to provide the funds to sustain it. There were suggestions for GTUC to move away from relying on donor funding and to build its own internal resources for running the women's committee. Others blamed the inefficient dues collection system of the GTUC as the cause of its financial problems. Some felt that the dues received were adequate to cover the activities of the women's committee; whatever bottleneck perceived was more a question of political will. Others demanded special space for meetings and administrative work. A space for meeting provides a conduit for reaching women in the trade union and promoting contact between women leaders and members on one hand and the national union and the confederation on the other.

Women leaders recognise the opportunities offered by the women's organ and women-only events beyond capacity building and believed that an efficient functioning women's committee should provide more space for women leaders in the 
trade union structures. Those who had the occasion to be involved early in trade union gender promotional activities saw women's organs as instruments that could offer space for women to come together to fight for their rights. They demanded the inclusion of Women Committee leaders who had voting rights on key decisionmaking bodies like the NEC of the national unions and the EB of the GTUC. There was concern also about the power that women leaders wielded at the regional level. Some felt that regional officers like the regional secretaries of the GTUC and Industrial Relations Officers (IROs) of the national unions had too much power in the running of the Women's Committees in the regions. They asked for a reduction in their power to determine who attended meetings of the Women's Committees in particular and trade union functions in general. The demands included regular branch and district meetings and a reliable database on trade union situation in the regions and districts.

Union bureaucracy was seen as being particularly instrumental in undermining the work of Regional and District structures of the Women's Committees. Seeking approval for carrying out an activity can take up to three or four months, women trade union leaders complained. All regional women leaders expressed frustration about the need to seek permission from Accra for every single activity. They felt that this could and did indeed stifle initiative. National union leaders were wary of granting too much autonomy to regional and district structures citing some experience of the GTUC in one region which amounted to the hijacking of union structures for personal gain. The need for some level of decentralisation was recognised but the balance between a central action and local autonomy was yet to be determined. Others felt however that if national leaders and desk officers would visit the regions and districts regularly then some of the issues of local autonomy and central control could be resolved. At the moment however they lamented that national leadership visits were tied to elections. 'It is only when they need our votes that they come to us in the regions. Once they get our votes we have to wait till the next election year.' 86 ICU members however made mention of efforts by leadership to inform members of events in the union. This effort was particularly helpful in producing some level of solidarity for the interim executive which was battling a court case with the immediate past General Secretary. The accusation of neglect was pointed at Gender Desk officers as well. Women leaders and members in the regions insisted that they did not know their desk officers. Women leaders of GAWU in the regions gave the example of the Gender Desk Officer who stood for elections at the Quadrennial Delegates Conference in January 2008, for the position of Deputy General Secretary and lost. They explained that few women delegates could identify with her because they had no contact with her. One explained she has better contact with the international community than with women members at the local level. This gender desk officer was however frustrated about the lack of funds for carrying out activities for

\footnotetext{
${ }^{86}$ Interview with union leaders, April, 2009
} 
the Women's Desk and felt that the worst thing that ever happened in GAWU was the choice to mainstream gender. This move killed all GAWU gender democracy strategies and caused it to lose its leadership role in initiating gender democracy within the GTUC she insisted. Others demanded a more direct intervention of the national leadership in the affairs of the locals and asked for national leaders to intervene at the local level to speak for women since male management heads of workplaces in Ghana were not sympathetic to women's needs.

On the whole national leaders were more likely to raise demands bordering on gender relations than leaders at the local level. The latter were more concerned with working conditions: access to workplace facilities, like equipment, uniforms and occasion to acquire skills and engage in income supplementing activities. The gender issues raised were the experience of sexual harassment, differential access to work place benefits and the use of pregnancy and child care to deny women access to training opportunities and promotion. National women leaders were more concerned about the use of gender democracy facilities to promote women's concerns in the trade unions.

Women's demands on their unions are varied and it appears that most women leaders bring to their unions problems beyond the workplace. There is a general conception that unions can and should solve all problems that women have, ranging from domestic responsibilities to health and workplace issues. Women's demands on their union showed that the roles they had assigned their unions varied. Top on the roles assigned was an attempt to get their unions to fill the gap in women's income earned and the satisfaction of their basic needs and provide opportunities for women leaders to build capacity. The demands also included the institution of efforts to promote the development of the Women's Committees. Women's demands on their unions suggest that they believed that their unions have sufficient capacity to deal with their issues but consistently renege because of the lack of a political will or the occupation of national leadership with issues that were of little importance to their members.

Women's demands, as a measure of their levels of consciousness, reveal how the ability of union structures to promote empowerment is constrained by the centralisation of union administration or bureaucracy. What this means for women's sense of autonomy and tools for impacting union structure and processes in their favour is immense. For if women operating in their separate organ are mandated by union rules to seek permission each time they take some initiative at the regional, district or local levels, then they might feel disempowered. The need to seek permission is one of the checks and balances in a representative organisation like the GTUC and the national unions. It is conceived to ensure transparency and accountability. However, it has the potential to stifle initiative and discourage mass mobilisation around a common cause, a critical tool in union arsenal for the promotion of workers' rights. It also holds in check the potential for autonomy for minority groups in 
the union. The major tool for acquiring influence, authority and power for the moment remains with individual women leaders at higher levels within union decision-making structures. The challenge is how this potential can be translated into group power and influence. This is investigated in the framework of the vision, goals and agenda they intend to pursue from their leadership location within their trade unions.

\subsection{TRADE UNION WOMEN LEADERS' AGENDA}

Framing claims and goals derives from one's conception of the responsibilities of one's representative organisations. The content of goals and vision are the driving force for pursuing a change agenda within the space occupied in any representative movement. Goals therefore can serve as tools for altering structures at the base of inequalities if they are framed in ways to target the real cause. Consciousness determines how unions are conceptualised and how unions will be utilised to secure such goals. The nature of the union goals as explained earlier provides an indication of consciousness as their formulation shapes how the solutions are framed. This then raises questions about what women see their unions as standing for and what use they will put their unions to or what problems they will rely on their unions to solve for them. The content of women's goals and vision also gives an indication of their notion of citizenship. The level of power acquired to alter union structures in women's interest will be determined by the extent to which the problems that they want their unions to solve address their under-representation in their unions. The content of goals therefore provides the tools which representative groups within movements utilise to pursue their change agenda.

The examination of goals sought to identify the direction of women leaders' efforts in shaping their unions in the interest of their members. The variations in the content of their demands, goals and vision that were outlined were not too diverse. The order changed though in terms of priorities. Most couched their visions within activities that concentrated on tackling women's survival needs, dealing with women's practical needs for income, welfare support, gender roles, and health care (Table 6.2a). Welfare support was important especially for women leaders in the GPRTU, ICU and CBMWU (see Table 6.2a).

Women trade union leaders wanted to use the women's committees to address women's workplace rights and responsibilities as well as gender issues like sexual harassment, the extension of maternity leave from three to six months. In addition they wanted to use the women's committees to address women's issues that were not covered by collective bargaining agreements like nursing breaks and workplace toilet facilities for women (Table 6.2b). They were expecting that the Women's Committees would serve as avenues for women to voice their workplace concerns within the trade union structures. 
Table 6.2a Support for Women's Survival Needs

\begin{tabular}{|c|c|c|}
\hline Content of Vision & Specific Issues & Unions \\
\hline $\begin{array}{l}\text { Income generation } \\
\text { or } \\
\text { supplementation }\end{array}$ & $\begin{array}{l}\text { a. Seed capital for trading } \\
\text { b. Teach trade/Skills training - e.g. beads making, retailing } \\
\text { c. Income generating activities to supplement low wages- } \\
\text { powder, soap. Cultivating soya } \\
\text { d. Credit union, revolving fund and hire purchase }\end{array}$ & $\begin{array}{l}\text { GTUC } \\
\text { ICU } \\
\text { CBMWU } \\
\text { GAWU }\end{array}$ \\
\hline $\begin{array}{l}\text { Welfare and } \\
\text { social support }\end{array}$ & $\begin{array}{l}\text { a. Support for funerals, weddings and sickness } \\
\text { b. Fund to increase commitment of members }\end{array}$ & $\begin{array}{l}\text { GPRTU } \\
\text { ICU } \\
\text { CBMWU }\end{array}$ \\
\hline $\begin{array}{l}\text { Gender roles and } \\
\text { health }\end{array}$ & $\begin{array}{ll}\text { a. } & \text { Marital counselling } \\
\text { b. } & \text { Housekeeping Cookery lessons } \\
\text { c. } & \text { HIV/AIDS education } \\
\text { d. } & \text { Health education - menopause }\end{array}$ & $\begin{array}{l}\text { GTUC } \\
\text { ICU } \\
\text { CBMWU } \\
\text { GAWU }\end{array}$ \\
\hline
\end{tabular}

Source: Field data: 2008

Table 6.2b Women's Workplace Rights and Responsibilities

\begin{tabular}{|c|c|c|}
\hline Content of Vision & Specific Issues & Unions \\
\hline $\begin{array}{l}\text { Workplace rights and } \\
\text { responsibilities }\end{array}$ & $\begin{array}{l}\text { a. Voice about working conditions } \\
\text { b. Women's problems in the workplace/women's rights in } \\
\text { the workplace } \\
\text { c. Sexual harassment } \\
\text { d. Unique needs that collective bargaining does not cover } \\
\text { e.g. nursing breaks, toilet facilities at workplace } \\
\text { f. Maternity leave }\end{array}$ & $\begin{array}{l}\text { GPRTU } \\
\text { GTUC } \\
\text { CBMWU } \\
\text { GAWU }\end{array}$ \\
\hline
\end{tabular}

Source: Field data: 2008

Others wanted to use the women's committee for addressing women's issues beyond the workplace, like unemployment among young females in their district, assist market women, campaign against child labour and high maternal mortality rates as well as organise clean up campaigns. The concern to utilise women's organs to reach unemployed girls raised by women in the Central and Northern regions and GAWU women leaders' interest in child labour was an indication of how peculiar local social issues attracted the attention of women trade union leaders.

In terms of the incidence of poverty, the Northern and Central Regions hold the third and fourth positions from the last end of the poverty league table in Ghana. It comes therefore as no surprise that women in such localities should be concerned and want to use their position within their unions as a tool for addressing social issues that confront them in their localities. By including local social issues on their union agenda, women leaders were giving an indication of their readiness to venture into communities using their union structures.

The desire to improve women's survival and workplace needs did not detract the attention of women leaders from pursuing the expansion of women's space and participation in their unions. Some women leaders were particularly concerned 
about improving opportunities for women's trade union education and capacity building to facilitate their entry into trade union office (see Table 6.2c). All women trade union leaders stated, as part of their vision and goals, the desire to ensure that trade union education was available for all women members. For them, access to trade union education was the one tool that empowers women and gives them an occasion to pursue their rights and develop their sense of union ownership (Table 6.2c). Other goals outlined included getting women's concerns mainstreamed into trade union activities and structures. The desire to get the Women's Committee to serve women's interests was expressed variously as 'serve as women's mouthpiece' or 'use the women's committee to get women's potential known'. The ultimate vision of some women leaders in the GTUC and ICU, was to use the women's committees to support a woman into high union offices like the Secretary-General or General Secretary (Table 6.2c). Trade unionism has changed, one explained. 'It is now about the brains and no longer about muscle power so women can hold high union office because they have the brains'. ${ }^{87}$

Table 6.2c Improve Women's Operation in the Trade Unions

\begin{tabular}{|c|c|c|}
\hline Vision Content & Specific Issues & Unions \\
\hline $\begin{array}{l}\text { Education- } \\
\text { seminars and } \\
\text { workshops and } \\
\text { capacity building }\end{array}$ & $\begin{array}{l}\text { a. Higher education women have lower education } \\
\text { b. Upgrade women's professional competence } \\
\text { c. } \\
\text { d. } \\
\text { e. }\end{array}$ & $\begin{array}{l}\text { GTUC } \\
\text { ICU } \\
\text { MDU } \\
\text { CBMWU } \\
\text { GAWU } \\
\text { GMWU }\end{array}$ \\
\hline $\begin{array}{l}\text { Representation } \\
\text { and participation }\end{array}$ & $\begin{array}{l}\text { a. Get women's concerns known to all/Mainstream women's con- } \\
\text { b. Pursue women's rights/ serve as a mouth piece for women } \\
\text { c. Give women voice in the trade union/Give women chance to } \\
\text { d. Goice concerns to stop men form looking down on them } \\
\text { positions } \\
\text { e. Get members to understand that unions not only for leaders } \\
\text { f. Get women to represent women on EC } \\
\text { g. Get women to hold high union office like general secretary not } \\
\text { only 2nd vice: militancy out of unions leaders use their heads not } \\
\text { h. Provide workplace assessment on levels and nature of women's } \\
\text { representation }\end{array}$ & $\begin{array}{l}\text { GTUC WR, } \\
\text { AR: } \\
\text { MDU, WR: } \\
\text { GAWU, } \\
\text { GAR } \\
\text { ICU AR: } \\
\text { CBMWU } \\
\text { GAR }\end{array}$ \\
\hline
\end{tabular}

Source: Field data: 2008

${ }^{87}$ Interview with female trade union leaders, May, 2008. 
The desire to make the women's organs at the national, regional, and district levels function effectively featured high on the priority lists of women leaders. The women's committees at the various levels, it was envisaged, could serve as the tool to empower women and increase their participation in the trade unions. Women leaders in the GTUC, ICU, CBMWU and GAWU in particular wanted the women's organ to serve as a networking platform for sharing ideas, experiences and building unity (Table 6.2d). Others wanted to use the women's committee to generate information to feed trade union decisions and action on women. There were those whose aim was to source funding to ensure that their women's committees could function. While some were considering writing proposals to source funding from the international donor community and District Assemblies, others were considering setting up income generation activities and to utilise the proceeds to support the work of their women's committees (Table 6.2d).

Table 6.2d: Improve the functioning of the Women's Committees

\begin{tabular}{|c|c|c|}
\hline Content of Vision & Specific Issues & Unions \\
\hline Women's Committee & $\begin{array}{l}\text { a. Use as platform for sharing ideas, experiences, network- } \\
\text { ing, and building unity/forum for coming together } \\
\text { b. Organ or space to organise or empower women so they } \\
\text { can own part of the union/Promote women's active par- } \\
\text { ticipation in trade union structures } \\
\text { c. Coordinate activities of women's committees/serve as } \\
\text { d. Provide information for national unions/advice leader- } \\
\text { e. Allow women to come up with suggestions for building } \\
\text { f. Create awareness about the existence of women's organ } \\
\text { g. Generate funds/write proposals for support to organise } \\
\text { programmes for women }\end{array}$ & $\begin{array}{l}\text { GTUC } \\
\text { ICU, } \\
\text { CBMWU } \\
\text { GAWU }\end{array}$ \\
\hline
\end{tabular}

Source: Field data: 2008

The plan to use women's organs to respond to women's survival needs pointed to the way women identified their union space. First, the unions were considered as organs for providing survival needs directly or providing women opportunities to supplement their low incomes and secondly take up the provisioning role of the state. There was little talk about how union structures could be used to compel the state to take up its provisioning role or get employers to pay wages and salaries that would provide sufficient incomes for workers to meet their needs. This suggests an acceptance by women union leaders that the state and/or employers were not responsible for providing a living wage for its workers. They would rather want workers and their organisation to fill in the income shortfall. Not only did women leaders set goals for their unions to supplement low earnings, they also were positioning themselves to use the space within the unions to provide welfare support and health education. In addition, they wanted to use their women's organs as a 
channel for alleviating the impact of their domestic burdens on their employment lives.

Using the women's organ as a vehicle for seeking support for women's gender roles suggests a tacit acceptance by these women that domestic work was women's responsibility. They had not set out to challenge this unequal burden of housework on women but rather to use women's space for reducing the demands that house work posed for women. In terms of collective consciousness, as distilled from their demands, vision and goals, women leaders were focused on ways to make women function better in their traditional roles. The vision and goals of women leaders however were very clear about the empowering potential of women's committees and all were desirous of investing their efforts in its survival and efficient functioning. Thus consciousness about the potential of union education on individual women is leading to more demands for union education.

\subsection{SUMMARY AND CONCLUSION}

This chapter set out to examine women's involvement in efforts at altering union structures for the pursuit of gender democracy within the GTUC and case national unions. The chapter was interested in exploring gender democracy strategies in ways that would highlight women as active agents through the way they articulate their concerns and utilise union structures and processes to their benefit. The framework adopted was underpinned by the notion of power redistribution to oppressed groups in representative institutions as outlined by Behrens et al (2004a). This was expanded to incorporate consciousness as a measure of women leader's ability to utilise existing structures to pursue claims. Consciousness shapes the acquisition of tools like power, authority and influence to generate additional demands for pursuing more claims. The cyclical approach pointed to how each process that leads to the acquisition of influence and power formed the basis for developing more claims for more power which in turn influences union strategies to transform unions.

Women trade union leaders blame low female representation and participation on unequal sexual division of labour, differential access to training and sex stereotyping in labour market access. Within the trade unions existing barriers like women's exclusion from union activities, the shaping of union activities to suit male lifestyle and prioritising male interests over female's were additional culprits cited. Gender democracy strategies in general, involve the creation of independent or separate organs and events and capacity enhancement activities to improve representation. Such approaches are embedded within union constitutions and provided supporting administrative structures. The inability of union strategies to achieve their desired impact has been attributed to union ideology, existing forms of power relations and patriarchal norms. Strategies that focus on institutional structures that undermine women's positions in the trade unions have greater capacity to trans- 
form union gender deficit than those that concentrate on women and attempt to develop their capacity.

The GTUC's gender democracy strategies began in 1969 and to date it has in place Women's Committees covering national through regional to district levels. All national unions also have their own Women's Committees at the various levels. These structures are supported by a Gender Desk which has responsibility for implementing the GTUC's gender policy and coordinating the Gender Units of the national unions. The GTUC and national unions use the two-pronged approach of separate organs to improve participation and special representation to address disparity in representation. These strategies have been given institutional anchor through constitutional amendments and a policy framework. Women's representation has improved within the GTUC and its national unions over the years. However, in terms of their relative standing to the male counterparts, women still remain marginalised in trade union structures. The improvement in women's representation and participation varies within the national unions. Male dominated unions like the GPRTU and MDU have recorded lower levels of success. ICU and GAWU have made better progress. The 1990s presented the GTUC and its national unions the most active period for pursuing a consistent gender democracy agenda. Though GAWU played a pioneering role in being the first to embark on gender democracy strategies, it has lost out with the cessation of funding. ICU however appears to be providing greater room for the operations of its women's committees, GPRTU provides the least opportunities for its women members.

Women require some stimulus to get into trade union work, and this is provided in the form of chance encounters that bring them to the notice of union leadership. Most begin with negative perceptions about their unions which get dispelled with increased trade union exposure and education. Factors constraining women's participation in trade union activities include their sense of union utility and ownership of unions, male resistance and hostility compounded by hostility of management. Females in male dominated unions like CBMWU, GPRTU, GMWU and MDU were more likely to face higher levels of male resistance than in less sex skewed ones like ICU and GAWU. Women's ability to cope with the demands of domestic work and occupational responsibilities as well as with trade union work was greatly enhanced by their understanding of the importance of unions and the presence of family support. Domestic support is critical in the lives of women trade union leaders. Their mothers, in particular, and husbands to some extent, were important factors in providing that support. This indicates how dependent trade union work as currently structured feeds on women's unpaid domestic work. Female union leaders have to navigate the delicate balance of acceptance by female and male trade union members and leadership. In the end they might achieve acceptance in male domains by acting like men and lose out in female domains largely because of the ambiguous link between women's organs and women trade union members. 
The women's committees were mainly inactive. Most were under-resourced or simply starved of funding, and none of the unions had maintained consistent and adequate funding beyond donor largesse. The absence of funding was blamed on lack of political will and absence of commitment for the women's committee by male trade union leadership. The manner in which women committee meetings were fashioned out made them very expensive to run, further complicating funding problems. Again, the highly centralised system of decision-making stifles initiative and constrains autonomous fund raising. The relations between the Gender Desk and the Women Committees were unclear and so were those between Women's Committees in the GTUC and the national unions. The institutional isolation of women leaders and their organs denied them constituency support and mobilisation base to wield power and authority to back demands on the unions. As a result, there was very little space for the development of women's agenda within the unions for systematic following. Few occasions existed for women representatives to interact with female members, renew a sense of constituency and foster commitment to a common agenda that leaders might carry into the unions with their mandate. The NGOs and religious spaces appeared to offer women more occasions and support framework for meeting their challenges as trade union leaders.

Such heavy challenges notwithstanding, the presence of several women ready to take up leadership positions in the face of the challenges was seen as a major achievement for the implementation of gender democracy strategies. Women's demands, vision and goals which were used as indicators of their levels of consciousness and potential to utilise space provided by gender democracy strategies showed different levels of awareness influenced by location within the union structures. This was used to determine whether they felt resigned to their situation or felt empowered to embark on process for change. Women's demands targeted mainly women's work in the trade unions, trade union structures and women's gender roles. The demands showed that unions assumed a large space for problem solving, especially in terms of meeting state responsibilities and employer refusal to pay decent wages. The visions and demands were similar in content and only differed in terms of priorities. The union and industrial location of women leaders were likely to affect their vision and goals for their women's committee, with informal economy based unions, like GPRTU and ICU, and low-income unions, like the CBMWU more interested in using their women's committees to solve their income problems directly. Welfare issues were also important for GPRTU and CBMWU women leaders. Improving the health of the women's committee and women's capacity in the trade unions also provided content for women leaders' visions

A major achievement of union gender democracy strategies in the GTUC and its national unions has been the increased participation of women in trade union decision-making structures. Union education had also created a core group of women ready to take up trade union positions beyond those reserved for women. The weakness of the strategies has been the focus on women and little attempt to im- 
prove the operations of the women's committees within union structures. There appeared to be more stress on individual gain of women's participation in their trade unions than the growth of women as a collective within the trade unions. The awareness and consciousness of women's gendered location within their unions were embedded in the demands for trade union education to build women's capacity for union work. Though there appeared to be some measure of awareness and consciousness, the occasion to translate these into community building, and into the notion of shared identity and commitment to a common women's cause was missing. Women's structures were not providing opportunities for women to come together and build a sense of community, solidarity and bonding to pursue their gender concerns. The stress on individual effort leads more to how to build individual capacity. Perhaps a shortfall of the top down approach to dealing with union gender democracy.

The site of women's encounter with their unions determines the manner in which women frame their demands and the context which shapes the goals they set for addressing their demands. Gender democracy, despite its limitations, was bridging an important gap that was the distance between women and their trade unions and providing the occasion for women to connect with their unions. Another important site around which women stood to develop their potential to build agency was how slowly men were beginning to accept women on trade union structures. This suggested that a system of continuous process of strategies that beget consciousness leading to an acquisition of tools for altering the internal trade union gender dynamics to further the institution of alternative strategies to deal with the different levels of resistance or failures in existing strategies.

The fact that women's demands were moving beyond just individual capacitybuilding suggests mainly that women leaders within trade union structures at the national level were making more gendered demands and raising more questions than those at the lower levels. The opportunity to serve on trade union structures constituted important steps for raising awareness and developing consciousness. The test is how such individual consciousness translates into a desire to pursue a change agenda. The content of that change agenda also has implications for the development of power and agency. For the moment, the potential lies in strengthening Women's Committees. For the conception of the Women's Committee and what it does for women trade union members is high on union agenda. It appears however that the level of consciousness before the institution of gender democracy strategies is important as a measure of progress. As women leaders conceded, despite their disappointment with the present situation, some progress has been achieved especially at the individual level.

Though unions were failing to provide women with space for the articulation of their concerns in a consistent and engaging manner, women's awareness of this shortcoming proved an important indication of some level of consciousness. Such 
awareness formed the basis for the development of power and authority for providing some basis for mobilising to secure redress. Thus the shortcoming of gender democracy strategies in the GTUC and its national unions notwithstanding, the promotional measures have made the strongest impact on trade union women leaders and offers a site for women potential to push for further strategies that will lend themselves to a further transformation in gender democracy strategies. The realisation that union is about them and that they have a right to demand that their needs are met is an important site for building power. The challenge is how to connect these sites into mobilisation points that should generate some higher levels of power within the unions. This should provide the ingredient that should propel women to assert their right of ownership of the union. For the moment however the informal mentoring at play in the lives of women trade union leaders by their older women counterparts provides an important site for developing bonds and generating other sites for building solidarity and mobilising for change. 



\section{Chapter 7}

THE REGIONAL AND DISTRICT COUNCILS OF LABOUR OF THE GTUC 


\title{
7 THE GTUC AND THE REGIONAL AND DISTRICT COUNCILS OF LABOUR
}

\begin{abstract}
Studies have shown a strong connection between union influence and democracy either at the national, enterprise level or within union ranks. Several historical accounts highlight specific trade union and state relations in Ghana and note the various ways in which union leaders and members have responded to events that threaten union internal democracy. The GTUC has long recognised the role of internal democracy in strengthening union influence and survival. Included in GTUC's attempts at combating the challenge of globalisation, are strategies that seek to improve the functioning of participatory structures at the regional and district levels. Union renewal strategies that target participatory structures do impact union internal democracy by altering the conception of their operational remit as well as their potential to offer members adequate power tools to pursue their interests. This chapter explores how the district and regional structures of the GTUC provide the necessary conditions for members to utilise their unions for the pursuit of their interests. It notes how membership size, sense of union relevance, networking avenues and the community connection made DCLs and RCLs important mobilising and solidarity building points for union action. These avenues therefore served as important power tools that could be marshalled to secure union rights. However the structural location of the DCLs and RCLs as well as the absence of committed resources hamper members' access to and utilisation of, such significant power tools. The optimism of DCL and RCL executives about the functional utility and empowering potential of these structures are also important power tools that should be recognised in all attempts at securing better connection between the national structures and their regional and district counterparts.
\end{abstract}

\subsection{INTRODUCTION}

Discussions on trade unions and democracy cover two areas: internal and external democracy. The first deals broadly with the manner in which trade unions as representative organisations are governed and the second explores the impact of trade unions on workplace democracy as well as national political and economic institutions (Wood 2004c: 19). The conclusions on union ability to impact national policy direction or governing structures have been largely determined by the theoretical perspective from which they are discussed. The perspective in addition dictates the 
specific issues that are examined. Marxist and radical traditions have been occupied with the potential of trade unions to lead workers' revolution for the overthrow of capitalist mode of production; the neo-corporatists and liberal economists however, limit their insight to how union actions impact the national economy.

In his review of theories on union internal democracy, Wood distinguishes between the pessimists who condemn unions to oligarchy incapable of sustaining internal democracy, from the optimists who insist on the strength of union structures to maintain internal democracy (2004c). The pessimistic bureaucratic or elite theories draw largely on the basic tenets of Michels' iron law of oligarchy that has set the framework for discussions on trade union leadership and membership relations. This law, we recall, posits that unions' desire to maintain efficiency, acceptability and predictability call for the establishment of bureaucratic structures that distance leaders from members, weakening the power of members to hold leaders accountable (Michels, 1959). The pegs of union office create union elites who identify more broadly with the political ruling class and less with their members (Michels 1959). The result of aligning the interests of union leaders to those of the ruling elite is a gulf between union leaders and members and a corresponding undermining of union internal democracy (Wood 2004c).

There have been several efforts to counter the law on oligarchic inevitability of trade unions. This optimistic position is set within Weber's rendering of bureaucracies that maintains that formalised representative organs contain sufficient mechanisms to ensure that leaders remain accountable to their members. Hyman quotes Gouldner's 'iron law of democracy' as representative of theories that assert the natural tendencies of rank-and-file organisations to constrain their leadership oligarchic tendencies (Hyman 1978). Such optimistic positions have shown how union members in several instances have used a variety of approaches both democratic and non-conventional to call their leaders to order and to direct their unions to serve members' interests. Several studies on trade union history in Ghana underscore membership capacity to bring self-seeking leadership to order and get union leaders to be guided by membership interests (Britwum A. O., 2007; Adu-Amankwah K. , 1990; Crisp, 1984; Kraus, 1988; Jeffries, 1978).

The exclusive focus on internal or external democracy has not always overlooked the connection between the two. The two sharply contrasting views prioritise one over the other. Where external democracy is prioritised over internally democracy unions are held as a threat to national democracy. The concessions that strong politically influential unions are capable of securing from the state can undermine prudent micro economic policies like cuts in government social spending. The radicals posit internally democratic unions as an important ingredient for the pursuit of social change and crucial for broader social democracy (Frege \& Kelly, 2004; Wood, 2004). Wood concludes however, that trade union internal democracy is crucial for both national democracy and economic growth. Trade unions he explains serve 
both as mechanisms for articulating the concerns of the rank and file while at the same time promoting sustainable micro-economic policies.

Roper (2004) however shifts the debate to engage the ability of the national economic policies to promote democracy and ginger citizen confidence in governments. For him, even though neo-liberal reforms operate under plural democracies, they rather nurture the environment that supports the curtailment of workers' rights. The general apathy to democratic participatory processes, like elections or the 'democracy crisis', underscores citizens' disengagement from liberal democracies in developed countries. It is rather social accords that have offered greater room for citizen participation in policy making by promoting policy ownership and narrowing the space between governments and their people (Roper, 2004).

Studies on trade union external democracy in Africa were initially informed by the 'labour aristocracy' thesis which positioned trade unions as parasitic institutions who together with the ruling political class exploit the productive surplus of rural peasant producers (Jeffries 1978). The attention shifted to the examination of union role in transition to political liberalism under multi-party democracies in Africa (Kester \& Sidibe, 1997). Others concentrate on workplace democracy insisting that democratic workplace participation between workers and management is not only healthy for enterprise productivity but promotes democracy in social and political spaces beyond the workplace (Kester G. , 2007).

Most research on trade unions in Ghana have shown keen interest in the development of trade unionism, union struggles, features of union militancy, especially within the colonial and independent states. Others have tried to identify sources of union power in order to account for the outcome of union struggles (Britwum 2007; Kraus 2007a; Hurd 2004; Wood 2004a; Konings 2003; Kester and Sidibe 1997; Kraus 1988; Crisp 1984; Hyman 1978; Jeffries 1978). Additionally studies on Ghanaian unions have examined union capacity to engage capital and state instruments of control. Union/state relations have been of exceptional interest to union researchers who have been exploring trade union behaviour in developing countries, particularly in Africa, and their specific relations with the state (Kraus, 2007; Konings, 2003; Adu-Amankwah \& Tutu, 1997; Kraus, 1988; Crisp, 1984; Kester \& Sidibe, 1997; Jeffries, 1978). The general trend revealed that trade union state relations have vacillated between cooption, accommodation, autonomy, compromise and hostility (Britwum A. O., 2008; Kraus, 2007; Konings, 2003). These varying forms of relations discussed in Chapter three have at times bolstered union power or curbed it altogether. In some instances state cooption has enhanced union visibility on the labour market and increased union bargaining power in the workplace. Such successes have been attained at the cost of membership support; and while union gained in fame from government largesse the distance between members and leadership widened. Union subordination by the state irrespective of gains in influence and power 
is always inimical to membership support and control over their unions (Britwum, 2007b; Kraus 2007b; Kraus 1988).

The GTUC has long recognised the importance of internal democracy for strengthening union survival and increasing union influence (Britwum 2007). Ghanaian trade union history is one of endless struggles between members for control over their unions, either with their leaders against the state or against co-opted leadership and the ruling government (Britwum 2007; Panford, 1996; Kraus 1988; Crisp 1984Error! Reference source not found.. It is thanks to this inexorable struggle that the GTUC has been able to retain its autonomy and maintain its influence to remain a credible labour movement in Ghana (Britwum 2007; Kraus 1988; Crisp 1984).

Years of membership decline experienced under Ghana's SAP demanded the institution of strategies to check the decline in union membership and maintain its legitimacy and influence as the leading organ for securing workers' rights. Such efforts included a revamping of union participatory structures the DCL and RCLs. Enhancing the operations of participatory structures where members engage their unions is bound to bring to the fore certain issues that border on union internal democracy. This is because union democracy encompasses a system of rights that are extended to union members. Such rights are enshrined in union constitution and are exercised through union structures and processes. Union structures that hold members therefore form an important location for examining internal democracy. In exercising their rights as union members, workers connect the interface between union internal and external democracy.

This chapter and the next (Chapter Eight) set out to explore how union structures in the regions, districts and enterprises provide the necessary conditions for members to pursue their interests in the workplace and beyond. The information is derived from field studies and union documents as outlined in chapter 3.88 Union leaders located in the regional and district councils of labour of the GTUC, the Regional Secretaries and officers as well as local union leaders of the six case study unions (CBMWU, GAWU, GMWU, GPRTU, ICU and MDU) constituted the main source of information. Others were officials of the national labour Commission and national leaders of rival unions.

\subsection{EXPLORING UNION INTERNAL DEMOCRACY: ISSUES ARISING}

Theories on trade unions and democracy have been interested in the way unions are governed and their potential to alter national governance. They have been compelled as a result to deal with the interface between union internal and external democracy usually within two contrasting opinions. The important conclusion

\footnotetext{
${ }^{88}$ See Chapter Three for details of data gathering methods and appendix A for the list of participants covered.
} 
however is Wood's assertion that unions and whatever they do is inherently bound up with questions of democracy either at the level of national, enterprise or within their own ranks (Wood 2004a). Union struggle for internal democracy and the larger struggle for social power and control are interrelated (Wood, 2004a).

The world of work and the corresponding relations evolved demands that workers develop the might to secure gains from their productive labour. The state, by virtue of the space it occupies in mediating different sources of power within production relations, tends to circumscribe benefits unions can derive for their members. Unions have been forced by different circumstances to make strategic choices in structuring their relations with the state. Wood notes that such strategic choices are informed by the relative strength of unions derived from existing levels of internal democracy. The outcome of such choices also impact internal democracy (Wood 2004a). Several studies have shown that whatever the motive shaping union state relations, extreme state cooption of trade unions have always undermined internal trade union democracy. Even though cooption in some instances expand union public policy making space, membership control over leadership and the ability of leaders to identify with their unions have been undermined (Panford, 1996 (Crisp, 1984 Jeffries, 1978).

Flynn et al believe that two related issues underlie internal union democracy broadening membership space within the union policy making apparatus and enhancing leadership accountability to membership (Flynn, et al. 2004). The first deals with equity and underscores the adequacy of trade union claim as the true representative of working people. The second deals with accountability or control, highlighting the ability of union members to ensure that leadership pursuits are informed by membership interests. Membership control over leadership dominated discussions on union internal democracy with two disparate positions about the capacity of members to control their leaders. In the early 1980s, as union membership became more diverse, the question of granting space for partial constituencies gained currency forcing a re-conceptualisation of union democracy as participation (Flynn, Brewster, Smith, \& Rigby, 2004; Hyman R. , 1978).

The Regional and District Councils of Labour (the RCLs and DCLs), and enterprise based unions or the locals, form the structures where GTUC members and its affiliate national union are located. The RCLs, DCLs and the locals are the structures where union members engaged their unions and exercise their rights as union members. These structures therefore provide a good site for exploring union internal democracy in terms of how union structures operate to empower or disempower union membership. The fact that workers fight for recognition of their rights inside their own unions and also use their unions to pursue their rights makes the study of union democracy challenging. For example it is necessary to explain why union members have sometimes fought against their leaders or why unions have at times achieved influence without membership support. It is for this 
reason that a framework that assists the examination of the target and content of union membership struggles becomes appropriate for studying internal democracy. Crisp's labour control and resistance framework as well as Andræ and Beckman's labour regimes have provided the conceptual underpinnings for exploring internal democracy within the GTUC and the case study unions. The framework also borrows indicators from Kraus and Hyman to investigate union power that underlies union internal democracy ( Kraus 2007b; Andræ and Beckman 1998; Crisp 1984; Hyman 1978).

The concept of power relations allows union internal democracy to be conceptualised as part of the larger struggles of unions against labour control. The literature reveals that union struggles have been triggered by concerns which border on the social, economic and political-all of which have had implications for internal democracy (Andræ and Beckman 1998; Crisp 1984; Kraus 2007b). The interrogation of union democracy within membership structures at the regional, district and local levels adopted the power relations approach to identify factors that empower or dis-empower members in their engagement with their unions. This called for an examination of what workers struggled against, the content and location of their struggles, the tools with which they engaged these struggles and how unions facilitated the acquisition of such tools for their members. These issues have been captured in the figure 7.1 below.

Workers struggles in independent Ghana have been directed at the state because of its large presence on the Ghanaian labour market. The state has not been the sole target of union struggles. In other instances, union leaders have been at the core of members' agitation or protests. Union members have had to struggle against their leaders in order to access the real target of their agitation, their employers, whether the state or metropolitan capital (Crisp 1984; Jeffries 1978). Union leadership have been aware that in their precarious positions they can either strengthen or undermine their unions. Cases of splits and fragmentation have been the answer that some trade union members have resorted in order to ensure that their interests are served. That membership protests have often taken the form of union fragmentation and not a complete rejection of trade unions shows workers' primary conviction that unions are the main tools for struggle, for recognition and protection in the world of work and beyond.

One dimension of union struggles has been the abuse of political office for personal gain, kleptocracy as described by Gyimah-Boadi and Jeffries (Gyimah-Boadi and Jeffries 2000). In an earlier work, Jeffries had explained how self enrichment, corruption and the accompanying patronage it breeds impact workers and their trade unions through attempts by government officials or trade union leaders to win over union representatives through graft and thereby compromising union unity (Jeffries, 1978). Crisp made a similar observation in his examination of mineworkers union history in Ghana (Crisp 1984). Kleptocratic tendencies of political leaders 
affect workers directly through their impact on enterprises. A study of the railway workers in Ghana showed how the industry's fortunes were affected by self-serving interests of the Ghanaian management of the rail industry (Jeffries, 1978). Rathbone attributes the pervasion of kleptocracy within Ghanaian political and economic history to dearth of resources. He states that, irrespective of the political orientation of politicians in Ghana, whether

Social democrats or social fascists or whatever, ... behind the rhetoric lies an unmistakable struggle for scarce resources which acquire a heightened value simply because of their scarcity (Rathbone, 2003, p. 399).

Gyimah-Boadi and Jeffries' explain how kleptocracy destroyed Ghana's economy in the mid 1970s (Gyimah-Boadi \& Jeffries, 2000). The resulting decline provided a breach for the introduction of neo-liberal economic reforms that weakened Ghanaian unions. The Acheampong and later Akuffo regimes, (leaders of the military junta, that oversaw Ghana's retrogression into the worst forms of kleptocracy) compromised GTUC leadership through cooption in a manner that distanced union members from their leaders (Britwum A. O., 2007; Kraus, 2007; Gyimah-Boadi \& Jeffries, 2000; Crisp, 1984).

The use of political office for personal gain is however not limited to holders of state and enterprise office. Union leaders also have their share of such accusations. In Ghana therefore, unions have targeted state officials and union leaders not only in their struggle against capital's efforts to control their productive capacity but against such persons' use of office to secure personal gain and threaten union existence.

Workers fight against kleptocracy has provided several examples of how state cooption has affected union internal democracy and in so doing sharpened the connection between union internal and external democracy (Nugent, 1995; Crisp, 1984). Nugent notes that workers' struggle against kleptocracy is rooted in the ideological conception of the social enterprise of the state as an entrepreneur and provider of livelihood for all; and also as a social leveller ensuring that the benefits of the productive capacity of citizens are enjoyed by all (Nugent 1995). Workers' tendency to abhor any attempt to sacrifice the benefits of collective efforts for purely private ambitions of political and managerial office holders gains currency within this ideological conception. 

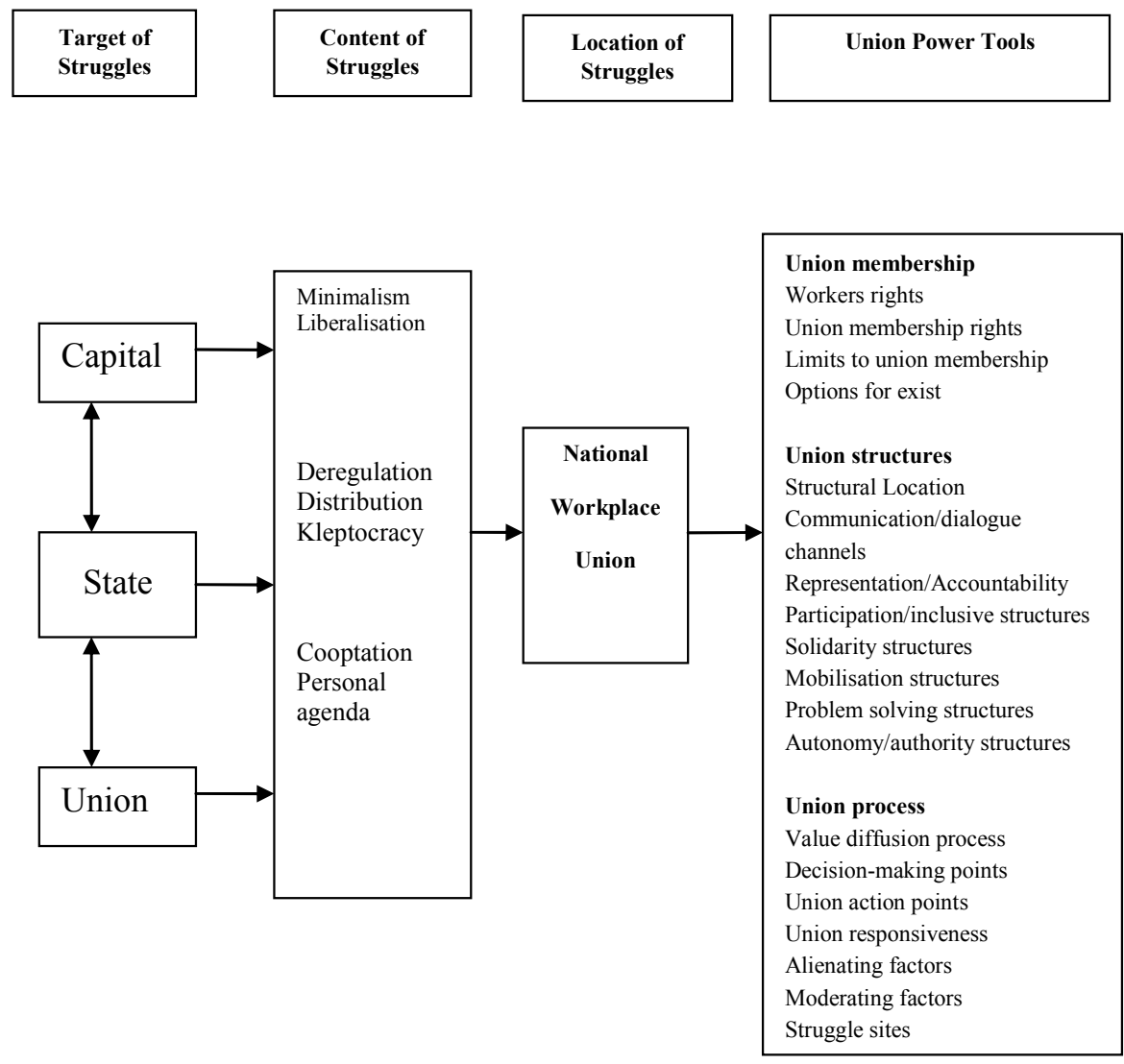

Figure 7.1 Exploring Union Democracy and Power

The core purpose of workers' struggles is ultimately to secure their employment and protect their rights whilst at work. Workers' rights are however, guaranteed by the freedom to organise, in addition to the power and influence their organisations develop for the pursuit of their interests. Factors impeding workers' rights are derived mainly from their employers, the state and capitalist owners of the means of production and their unions. Such factors determine the content and where the location of workers' struggles will be pitched; whether at the national, workplace or within their own unions. The tools unions provide workers for pursuing their struggles are located in the members, union structures or processes (Figure 7.1). Union internal democracy is the avenue for the mobilisation of such power tools for the pursuit of union struggles. This consideration informs the GTUC's efforts at revamping membership structures as an important component of union renewal strategies. The interest then is to identify how in their operations, union consultative structures facilitate or block workers' efforts at securing their rights in their engagement with capital, the state and the personal interest of the ruling political class. 


\subsection{COMPOSITION AND INSTITUTIONAL LOCATION OF RCLS AND DCLS}

The GTUC as a labour movement consists of a political and bureaucratic wing (see Figure 7.2 below). The political wing, where union policy is generated and interaction between membership and leadership facilitated, identifies the union as a mass representative movement. The union bureaucracy is the servicing organ that administers the labour movement (Britwum A. O., 2007). Positions within the political wing are secured through elections while entry into the administration is by academic and professional qualification.

The Secretary General, an elected officer, serves as the administrative head of the GTUC. Ultimate power over both the political and administrative wings lies however, with the QDC which has supreme authority for charting union policies and programmes and interpreting the constitution. Its decisions are final and binding on all. Because the QDC meets once every four years other policy making bodies like the Executive Board, Steering Committee, Executive Committee and the Finance Board carry out its functions in the interim. As a result, these national bodies wield considerable power in charting the direction of the confederation. The members of these bodies are the elected national officers of the GTUC and the national unions as well as heads of specialised departments of the GTUC. After these structures, in order of authority, come the Regional Councils of Labour (RCLs) and the Regional Women's Committees (RWCs) and finally the District Councils of Labour (DCLs) and their District Women's Committees (DWCs) (see Figure 7.2).

The DCLs and RCLs are structures that hold union members. They serve as channels between the GTUC's national structures and affiliate national union rank-andfile members in the regions and districts. The RCLs and DCLs have a direct link with the locals of the national unions who provide their membership. Chapter six has discussed the operations of the DWCs and RWCs. This chapter focuses on the RCLs and DCLs of the GTUC. The next chapter, Chapter Eight, will examine selected local unions of the six case study unions in the six selected regions mentioned in Chapter 3. 


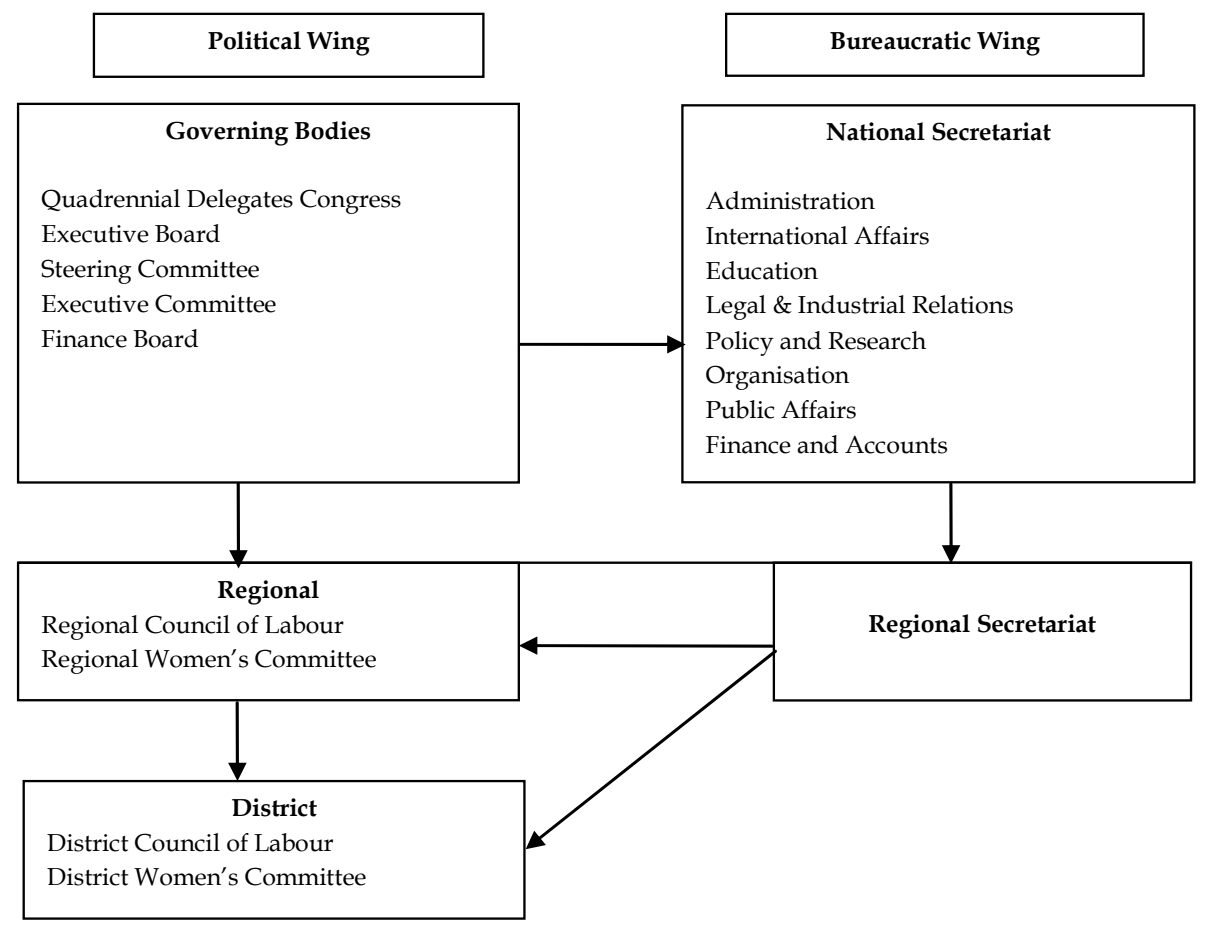

Figure 7.2 The RCLs and DCLs within the GTUC

Table 7.1 Composition of the Regional and District Councils of Labour

\begin{tabular}{|l|l|l|}
\hline Constituencies & Regional Councils of Labour & District Councils of Labour \\
\hline $\begin{array}{l}\text { Office bearers/elected } \\
\text { officers }\end{array}$ & $\begin{array}{l}\text { Chairperson } \\
\text { 2 Vice-Chairpersons, } \\
\text { Secretary } \\
\text { 2 Executive Members } \\
\text { Assistant Secretary } \\
\text { Treasurer }\end{array}$ & $\begin{array}{l}\text { Chairperson, } \\
\text { 2 Vice-Chairpersons, } \\
\text { Secretary } \\
\text { Assistant Secretary } \\
\text { Treasurer }\end{array}$ \\
\hline $\begin{array}{l}\text { Elected Women's Repre- } \\
\text { sentative }\end{array}$ & Representative of each DWCs & Chairperson the DWC \\
\hline Elected national officers & $\begin{array}{l}\text { Resident GTUC Executive Board Mem- } \\
\text { bers } \\
\text { Regional Chairs of National Unions }\end{array}$ & $\begin{array}{l}\text { Part-time National officers of } \\
\text { national unions }\end{array}$ \\
\hline Regional officers & $\begin{array}{l}\text { National union Regional Industrial } \\
\text { Relations Officers } \\
\text { GTUC Regional Secretary }\end{array}$ & $\begin{array}{l}\text { Regional officers of the GTUC } \\
\text { and national unions }\end{array}$ \\
\hline District/local officers & 2 representatives from all DCLs & $\begin{array}{l}\text { Local and branch union Chair- } \\
\text { persons and secretaries of the } \\
\text { National Unions present in the } \\
\text { district }\end{array}$ \\
\hline
\end{tabular}

Source: Constitution and Internal Regulations of the GTUC, 2004 
The DCLs and RCLs have similar profiles differing only in their scale of operations (Table 7.1). All local and branch union leaders of the national unions located in the district as well as the regional offices of the GTUC are automatic members of the DCLs in their respective districts. Other members include part-time national officers of the GTUC and national unions and the chairpersons of the District women's Committees (Table 7.1). The RCLs draw their membership from the DCLs. They are the elected officers of the GTUC and national unions in the region, one representative of each DWCs in the region as well as Regional Industrial Relations Officers of the national unions located in the region. The Regional Secretaries of the GTUC serve as secretaries (see Table 7.1). The executive committees of the DCLs and the RCLs are mandated by constitution to meet every quarter.

The jurisdictions of the RCLs and DCLs are aligned on the administrative demarcations of the country. The GTUC is slow in creating new districts in response to redemarcations and the creation of new districts. As at the time of data gathering, for example, all DCLs were operating under the district demarcations outlined in the year 2000, ignoring the new districts created since. Even though they operate along the administrative divisions of regions and districts in the country, worker concentration in Tema, the industrial hub of Ghana, has compelled the GTUC to designate Tema as a region. The presence of the national headquarters in Accra allows the GTUC to operate without a regional office. In effect, even though there are 11 labour regions, only 10 regional offices exist. Accra has none. The size of the executives of the RCLs depends on the number of districts, national unions in the region as well as the locals present. All RCLs are required by constitution to hold Executive Committee meetings once every quarter and membership meetings once a year. These provisions were incorporated in the amended constitution of the GTUC in February 1999 as part of the strategy to overhaul the RCLs and DCLs. The location of the RCLs and DCLs give the GTUC its national character. The functions of RCLs and DCLs are coordinated by one of the GTUC's specialised departments. In the late 1980s and early 1990s, they were placed under the Political Department set up in 1983. Later, in 1996, they were absorbed into the Education and Research Departments when the Political Department was scrapped on the recommendation of a consultant tasked to restructure the administrative wing of the GTUC. The coordination of RCLs and DCLs was, as at the time of data gathering, the responsibility of the Organisation Department.

The RCLs, RWCs, DCLs and DWCs are described as the consultative structures because they provide the platform outside the locals for union members to engage with the confederal body the GTUC. The RCLs, by constitution, have supervisory role over the DCLs and serve as a conduit for processing DCL reports and programmes. They also have the mandate to assess the implementation of GTUC programmes in their respective regions. The DCLs serve both as organisational and supervisory bodies of locals and branches of national unions present in their respec- 
tive districts. According to the GTUC constitution, the RCLs and DCLs are expected to act as policy implementing organs and offer a forum for social, educational and recreational activities for union members. While in the locals, union members will be engaging with their national unions and are more likely to raise workplace issues. The RCLs and DCLs are expected to take on board national and union policy issues. If properly functioning therefore, these structures should serve as mobilisation and solidarity points and help workers build a sense of continuity between workplace, community and national spaces.

Union records show however that the RCLs and DCLs have functioned mainly as a forum for receiving national officers who come to brief members about union activity. They have also served sporadically as mobilisation points for union action. Perhaps the best known example is the role of the Tema District Council of Labour (TDCL) in the run-up to multi-party democracy in Ghana. ${ }^{89}$ This militancy was confirmed during fieldwork when union leaders stated that;

The TDCL has a tradition of being vocal because it is made up of over 300 companies located in one area. TDCL is a convergence of locals from all the national unions so its concerns are usually national concerns. The TDCL for example was in opposition to the sale of Agricultural Development Bank because most workers in Tema save with ADB. TDCL is also a powerful forum for pressurising recalcitrant employers because employers compel the problem enterprise to resolve labour disputes in order to forestall solidarity strikes. It is easy to mobilise workers of Tema for protest action especially over national issues. Leaders of TDCL are on the heat all time because after meetings workers want to hear their leaders on the air. ${ }^{90}$

Under the Political Department, the DCLs were very active and acted as the platform for the development of programmes to raise membership's political consciousness. They also provided avenues for union members in the districts to make a direct input into the GTUC's agenda (Britwum 2007). This connection strengthened the influence of the GTUC in national policy, making space especially in the transition towards multiparty democracy in the early 1990s. Consultations within the DCLs also allowed the GTUC to sufficiently pressurise government to respond to union demands for a discussion of wage freeze, new minimum wage, as well as pending severance awards for retrenched workers of the Ghana Cocoa Board (Britwum 2007).

As a point of aggregation of union members from a diverse background, the regional and district structures, provide a platform for building rank-and-file unity and power base across the national unions for control over union leadership; and voice for placing and pursuing demands within the bigger labour movement. As pointed out in Britwum (2007), these are the structures that give the GTUC its char-

\footnotetext{
${ }^{89}$ See Graham, 1989 and Britwum 2007 for an account of the role Tema District Council of Labour as the nucleus of the Association of Local Unions that ousted the leadership of the GTUC in 1983.

${ }^{90}$ Interview with TDCL leaders, February,2008
} 
acter as a mass representative organisation. They also provide avenues for elected officers from enterprise, district and regional levels to participate in union decisionmaking and serve as a link between the governing structures of the GTUC and the members of its affiliate national unions. They, as one respondent put it, 'hold the potential to reinforce the presence of the GTUC in the regions and districts ${ }^{\prime 91}$. An important function, since the GTUC derives its members from the national unions. The DCLs and RCLs are the structures that give the GTUC some existence beyond its national leadership and therefore serve as an important constituency legitimising GTUC's existence as a confederal body. The DCLs and RCLs are the inter-union platform for fostering community building among workers located in the regions and districts of Ghana.

\subsection{THE STATE OF THE RCLS AND DCLS}

According to union historical records RCLs and DCLs were in operation in 1947 (Britwum 2007). Fieldwork findings confirmed this. Most of the executives interviewed could not give a date of the origins of the RCLs or DCLs. The councils of labour were generally characterised by inactivity. Respondents remembered efforts at reviving these structures. The three most active (TDCL, Saltpond and Yendie DCLs) out of the twelve DCLs covered were able to adhere to the constitutionally mandated quarterly meetings. The most dormant, DCL, (Nzema East DCL) had not met since 1998. The rest had managed two meetings a year. The motivation for reviving dormant DCLs usually comes from union educational meetings, notable ones were educational programmes organised under the African Workers' Participation Development Programme (APADEP92) and later, the Business Sector and Advocacy Challenge Fund (BUSAC). The general trend that emerged therefore was a cyclical movement from a period of activity when some event stimulates activists to revive the DCLs, followed by gradual declining interest and finally long periods of inactivity. Declining activity is usually heralded by low meeting attendance. Thus the problem that the most active DCL was facing was maintaining membership interests in scheduled meetings. The usual culprit blamed for inactivity was lack of funding. Somehow DCL inactivity has not disturbed the work of the GTUC and all bureaucratic procedures have been performed irrespective of the low performance of RCLs and DCLs.

The major activity mentioned by executives of the DCLs and RCLs interviewed were meetings which were held mainly on the instigation of the national GTUC office. Other activities mentioned were the yearly parades organised on May Day, the first of May, the internationally recognised workers' day. May Day parades are

\footnotetext{
91 Interview with ARCL executives June, 2008

${ }^{92}$ APADEP operated in 1994 to 2005 as a programme of collaboration between the GTUC and the Dutch Confederation of Trade Unions (FNV). It worked as a trade union and university partnership to enhance worker participation in decision-making through education and training, research and campaigning.
} 
held at two levels: the national, which involves national officers and is addressed by the President of Ghana; then the regional, which assumes the form of parades involving the locals of the region. The DCLs in each region take turns to host regional May Day parades. It was a source of pride for the DCLs who were able to attract and successfully host such regional parades.

Meetings of the RCLs and DCLs covered several areas of concern like government policy, workplace and union issues as well as leisure activities. Most DCLs and RCLs considered the educational content of meetings as being very important and explained that meetings were usually called for that purpose. The educational component of RCL and DCL meetings provided workers the occasion to learn their rights and responsibilities at work. The meeting topic most mentioned was the Labour Act, Act 651. Pension was another favourite educational topic at DCL meetings. Workers also received health education talks on HIV/AIDS. One DCL mentioned that some such meetings involved management. The management personal concerned was very happy about the occasion to learn. DCL executives justified the inclusion of management in union education as beneficial for the local unions. For them it did not help their cause to keep workers abreast with the contents of the Labour Act while management remained ignorant.

The meetings of the RCLs and DCLs act as a forum for members in the regions and districts to receive reports from the GTUC national offices. Their meetings were also used to plan union events like the May Day parade. DCL meetings additionally served as platform for accessing support for grievance handling, settling disputes between management and workers, as well as dealing with general workplace complaints that emerge at the locals. Meetings provide moreover a forum for the unions to identify leadership talents and set up a system of activists that can be recruited from the locals to support union work in the districts and regions.

The meetings also presented occasion to receive further insights into government policy and debate the implications of the policies for members' welfare. Issues such as the national elections, water privatisation and the single spine salary structure were mentioned. Thus the range of issues discussed at DCL and RCL meetings covered general economic, political and social concerns that impact workers life within and beyond the workplace. The DCL meetings were mentioned as providing the occasion to organise leisure activities for workers. One such activity that was popular and had the support of the national leadership of the GTUC was sessions of physical exercises dubbed 'keep fit clubs'. These were built around fitness exercises over the week-end to ostensibly encourage workers to develop and maintain the habit of engaging in physical exercises to boost their health. In practice however, the GTUC leadership hoped that 'keep fit clubs' could form a mobilising point for union members. 
The most recent RCL meetings mentioned took place in 2008 described as 'congress year', the year of the QDC. A series of nationwide RCLs meetings were tied in with one DCL meeting usually the one covering the regional capital. Three such combined RCL and DCL meetings were covered during the field work ${ }^{93}$. National union officers used the meetings to inform members about what they termed the 'GTUC's positions' on the Single Spine Salary Structure and the state of negotiations towards the development of this salary structure. Members were also provided information on the forthcoming QDC and, where necessary, the May Day celebrations were discussed. Members present used the plenary sessions that followed the GTUC leaders' presentations as a platform to engage the national leadership. The meetings, as a result, turned out to be question and answer forums where members raised a range of concerns from their workplaces, as well as general social and economic problems beyond the workplace.

All leaders of councils of labour interviewed expressed dissatisfaction with the state of their councils of labour in particular and the general inactivity of the RCLs and DCLs. They were certain of the important roles of these structures in the GTUC and the national unions. Most were especially concerned about the DCLs and felt that once a solution was found for activating the DCLs, the RCLs could overcome their inertia since it would be possible to subsume RCL into DCL activities.

The GTUC as mentioned earlier is aware of the implications of the present state of the councils of labour and has instituted efforts to keep them active. Attempts to rejuvenate the RCLs and DCLs, consists of the inclusion of mandatory quarterly meeting schedules into the GTUC constitution of 2004. Additionally, national unions were assigned financial responsibility for specific DCLs. These strategies are yet to provide the required stimulus for rejuvenating the DCLs. The GTUC, however, continues its search for solutions. The 2008 policy outline for the 2009-2012 quadrennial recognised the potential of these two consultative bodies to strengthen the union movement (GTUC 2008). The broad policy objectives for enhancing union organisation, deepening internal democracy and building union solidarity include:

- Membership expansion in both the informal and formal economies;

- Building solidarity, integrity and unity within the national unions;

- Deepening democracy; and

- Organisational cohesion.

The first three of the four objectives cited above are directly related to union internal democracy and the fourth is dependent on internal democracy. In fact the policy document underscores the link between intra union unity, integrity and stability and union internal democracy when it states that:

\footnotetext{
${ }^{93}$ These were meetings held in the
} 
It is important to uphold the principles and values of democracy at all levels of the trade union movement. Deepened internal democracy within the labour movement will engender greater respect for democratic principles to ensure unity, integrity and stability of unions. To this end it is necessary to develop and provide and maintain avenues for members at all levels to engage in discussions and debate on issues that are of concern to them (GTUC, 2008, p. 27).

Activities outlined for meeting these objectives include a recruitment drive, demarcation of union borders and policing union jurisdictions, dealing with union fragmentation, encouraging mergers, deepening union internal democracy and developing the capacity of union activists (GTUC 2008). Very little function has been assigned the RCLs and DCLs beyond a passing mention of the need for them to be 'oriented to support the recruitment efforts of the National Unions'. Under internal democracy, the policy document recommends:

- Regular meetings of all union structures both for the GTUC and national unions;

- Regular information flow on union activities to members;

- The establishment of a feedback mechanism for members to engage their leaders;

- Expansion of GTUC's presence in the activities of the national unions;

- Encouraging self-expression and a healthy culture of debate within the unions;

- Regular publications for dissemination of union news among the movement;

- Mass meetings on topical union and national issues;

- Encouraging national unions to finance RCLs and DCLs from their local union dues;

- Widening the space within GTUC for mass participation of the rank-and-file in union decision-making;

- Restricting office holders to limited tenure and developing leadership succession plan for national unions (GTUC, 2008, p. 28).

The RCLs and DCLs are mentioned only in terms of funding for their activities and helping to secure more union membership. The two structures however, stand to play key roles in the realisation of policy recommendations like the establishment of feedback mechanism, engaging union leadership, expanding GTUC presence in national union activities, mass meetings and mass participation of rank-and-file in union activities as well as self-expression. Here the policy recommendations present some level of conceptual and functional confusion of the role of the DCLs and RCLs in enhancing union internal democracy. This raises issues about the actual functioning of the Councils of Labour in the regions and districts and the extent to which the members can use these structures to pursue their interests.

\subsection{FUNCTIONAL UTILITY OF RCLS AND DCLS}

A summary of union leaders' conception of the function and utility of the DCLs revealed that this GTUC structure was viewed first and foremost as a source of 
union membership power for pursuing workers' interests in the workplace, and for engaging with government policy and unions (see Box 7.1). Union executives interviewed considered the DCLs as important GTUC structure in the districts because they provided a forum that engaged a large proportion of trade union members. One group of the DCL executives captured this fact succinctly by describing the DCLs as the 'highest union decision-making in the districts. They also enhance union credibility and profile ${ }^{\prime 94}$. At the national level, the DCLs were described as workers' mouthpiece in the district and a solidarity and mobilisation point for pressing demands on government and for engaging with national policy (Box 7.1). Union leaders insisted that the DCLs could serve as a pressure group to support GTUC's demands for reversing national policies that are inimical to workers (Box 7.1). They cited fuel price hikes in 2001 as an example and believed that the DCLs could have provided workers the forum to pass resolutions to pressurise government to rescind its decision to deregulate fuel prices.

Within the workplace, the DCLs provided a vehicle for workers to secure their rights as specified in the Labour Act, Act 651, 2003 and also helped with monitoring adherence to this Act. Some mentioned the active involvement of DCL executives in workplace grievance handling, insisting that workers' issues picked up by their respective DCLs receive better attention from employers than those handled by the local unions. Thus the DCLs boost the power of locals and shield local leaders against management victimisation. They also provided a platform for bridging the gap between workers and management (Box 7.1). One group of DCL executives mentioned this in reference to the involvement of management in DCL educational programmes mentioned earlier.

The functions of DCLs and RCLs in the union structures as outlined by executives emphasised their relevance. The DCLs were presented as the highest decisionmaking body of the GTUC in the district that workers used to guide and control union structures at the national level. They also served as platforms for developing union policies and disseminating union information. An effectively functioning DCL, it was insisted, should enable workers reverse the top down decision-making approach currently existing within the GTUC and its affiliates, 'members at the bottom will make union leaders sit up. We will tell them what to do and not the other way round'.$^{95}$ DCLs were also seen as sites for trade union education and the acquisition of leadership skills for trade union activism (Box 7.1).

\footnotetext{
${ }^{94}$ Interviews with NEDCL executives, May, 2008.

${ }^{95}$ Interview with DCL and RCL executives April and June, 2008
} 


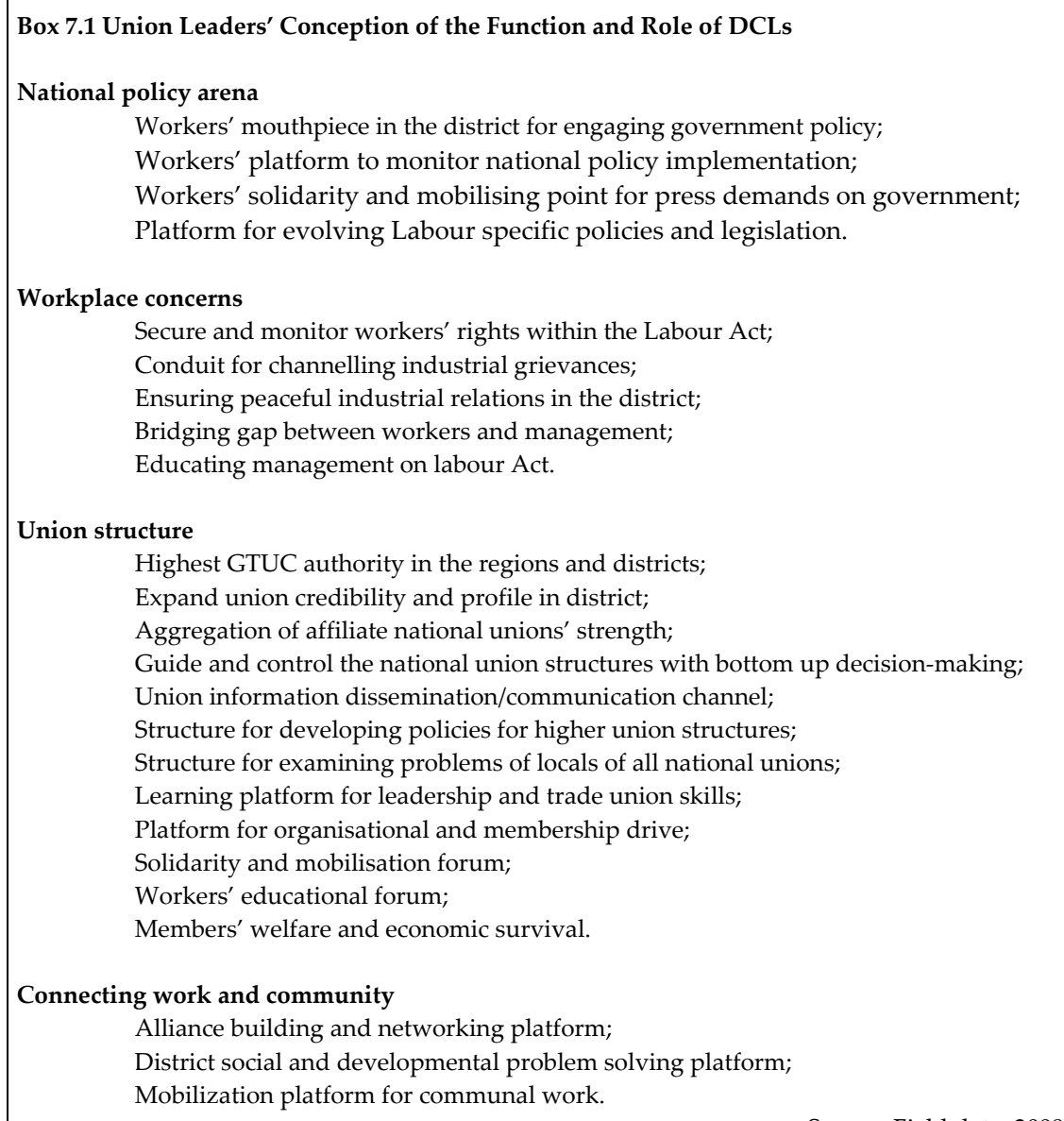

Source: Field data, 2008

Other functions outlined were the ability to connect workers in the district and provide a forum for networking with other labour movements like GNAT. Union leaders also made the connection between work and community and felt that the DCLs provided a mobilization point for engaging workers in programmes for solving social and developmental problems within their districts. The DCLs presented workers with a forum to engage in advocacy work with other civil society groups. One example given was election monitoring and child labour and trafficking in the districts. Effectively functioning, some executives explained, the DCLs could serve as bodies for monitoring the implementation of national policies in the district and for mounting vigilance on local government authorities just as the Executive Board of the GTUC does on the national scene. 'We are the eyes of the unions in the districts and we can provide information on the impact of policy on workers', some 
executives insisted. ${ }^{96}$ Other issues that emerged were the use of DCL meetings as a platform to engage in alternative income generation skills as avenues for workers to increase their meagre incomes and handle inconsistencies in tariff deductions.

Despite the displeasure, DCLs and RCLs executives were certain of the utility and relevance of regional and district councils of labour within the GTUC. Some were engaged in mobilising resources to ensure that their councils of labour remained active and meaningful for workers. The least active DCLs felt abandoned by the GTUC and insisted that they were too young to stand on their own ${ }^{97}$. In some districts workers were reluctant to make any sacrifices for the DCLs, citing that they paid sufficient dues to cover the activities of the councils of labour and disagreed with any idea for additional contributions.

\subsection{RCL AND DCLS CHALLENGES, INITIATIVES AND ACHIEVEMENTS}

The major constraint cited by DCL and RCL executives, inadequate allocation of funding, was blamed on poor financial management and accountability structures within the GTUC (Box 7.2). Very few bought into the low union subscriptions excuse. Like the female leadership of women's committees, most councils of labour executives interviewed insisted that it was political resolve and prudent financial management that would solve the resource problems facing the RCLs and DCLs, not additional finances. Financial constraints were attributed to the absence of a mandatory budgetary allocation that the GTUC is bound to and lack of clarity about who has responsibility for funding the regional and district councils of labour. RCL and DCL activities, as was explained at one group interview session, 'is capital intensive $\mathrm{e}^{\prime 98}$. Money is required to produce and distribute letters, pay for venue and refreshment for members who will be attending meetings as well as cover transportation costs. Since regional offices of the GTUC have poor office infrastructure, letters have to be printed and photocopied at private secretarial centres. The poor communication infrastructure in the country restricts the use of the postal system for sending letters. An officer has to be delegated to travel to hand deliver letters adding to the cost of meeting preparation. The refusal to allow independent fund raising was particularly frustrating for those executives who insisted that they had avenues for alternative funding outside the GTUC structures. At group interview sessions the executives insisted that but for the financial and accompanying resource constraints, the RCLs and DCLs would have been functioning and making the desired impact.

\footnotetext{
${ }^{96}$ Interview with DCL and RCL executives January to June, 2008

${ }^{97}$ Interview with GWDCL executives, February, 2008

${ }^{98}$ Interview with GWDCL executives, February, 2008.
} 


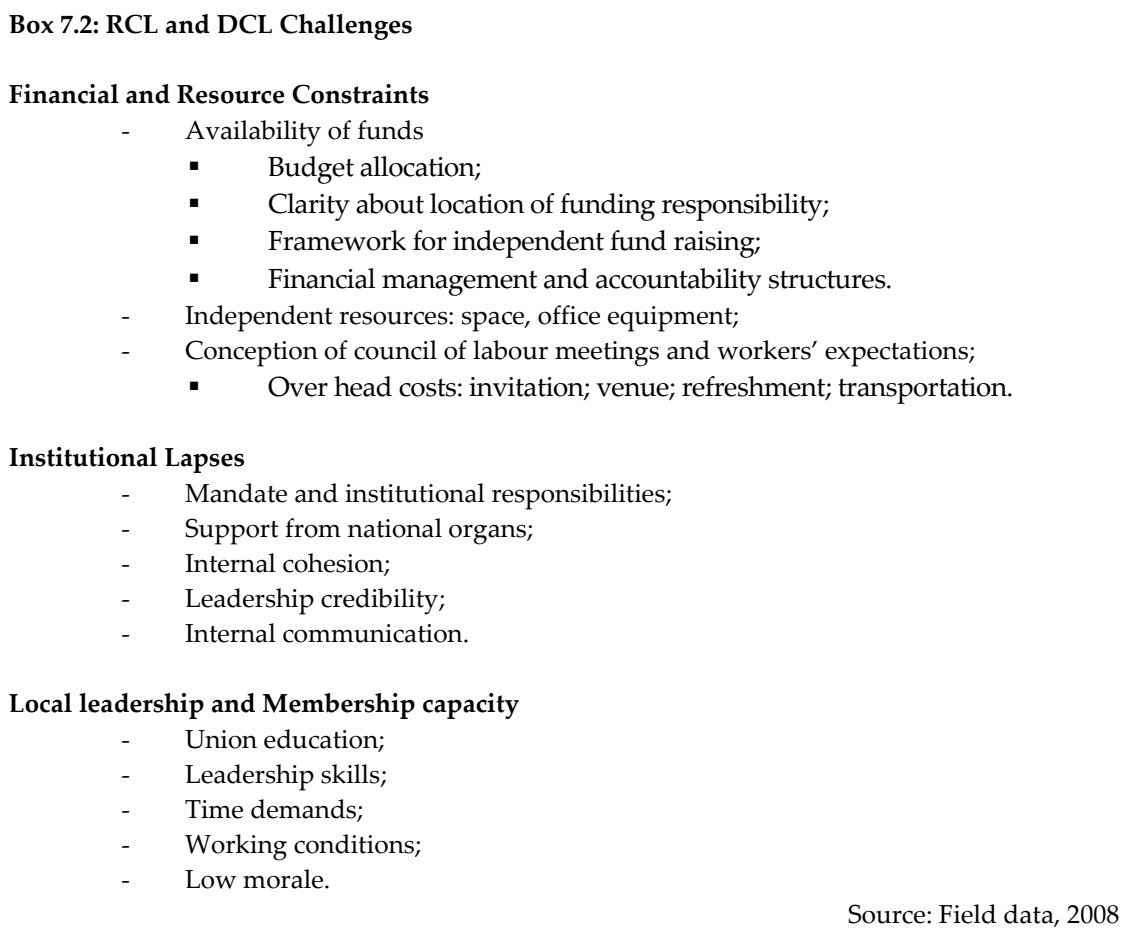

Other constraints identified were derived from the institutional location of the councils of labour within the union structures and their relationship with national union governing bodies. One such constraint identified was the limited mandate and institutional responsibility of the RCLs and DCLs. Most felt that the RCLs and DCLs did not have sufficient voice in union governance. This feeling was more pronounced at the district level where union executives explained that having to route their concerns through the regional secretariat to the national governing bodies reduced their ability to impact union and national policy. There were also complaints about the absence of authority to organise events. As was put at one interview sessions 'we are just there to receive orders from above' ${ }^{99}$. There was an expression of displeasure about limited avenues for consultation with national policy making organs and the absence of space to engage union decision-making. The situation was compounded by the lack of leadership authority at the RCL and DCL level.

${ }^{99}$ Interviews with NJDCL executives March, 2008. 
An examination of the constitutional provisions of the DCLs and RCLs reveal some patronising attitudes to these consultative structures. There appears to be some notion that these bodies are incapable of independent existence and require some supervision by the Regional Secretary who stands in a good stead to offer the direction required. The present system appears to give the Regional Secretaries power over the councils of labour leaving questions about who has the authority to call council of labour meetings. According to the constitution of the GTUC the Regional Secretary works directly to the General Secretary, the head of the national secretariat. The Regional Secretary also serves as the mandatory secretary to the RCLs and their Executive Councils. In figure 7.2 the arrow of authority moves from the Regional Secretariat to the RCLs and DCLs. The direction of authority is however, reversed for the nationally based policy making bodies, the QDC, the Executive Board, Steering Committee, Executive Committee and the Finance Board. They have power over the national secretariat. There was, as a result, some ambiguity about the final authority of the GTUC in the regions and districts. While some believed that power rested with the Regional Secretary, others objected. Some criticised as meddlesome, the right of the Regional Secretary to determine who should attend council of labour meetings. This absence of autonomy affected local initiatives and accounted for the refusal of some DCL executives to raise funds. DCLs executives who disapproved of Regional Secretaries' power over them were more likely to wait for union funds before undertaking any union activities and less likely to invest in their own resources.

The vagueness of leadership authority at the regional level had its impact on internal cohesion and there were accusations of regional secretaries who try to influence the outcome of RCL and DCL elections to favour their preferred candidates. Union executives also complained inadequate support from the national secretariat. Communication between the councils of labour and the national secretariat was a problem for most executives interviewed. They complained about the slow reaction to requests for assistance, saying that response to letters could take months, rendering whatever support that were offered obsolete. Some lamented the short notice given for executives to attend union events and the use of mobile phones to summon executives to the national headquarters. Part time officers require time and official documentation to notify their employers about union call to duty and to prepare their work assignments for their absence. Phone calls were considered inappropriate notices to secure official permission to stay away from work. Short notices also meant that people attending union events were usually not the executives, but those handpicked by the Regional Secretary. In the Western, Eastern and Ashanti regions however, the Regional Secretaries and the Chairpersons of the RCLs tempered the confusion about power and authority with good working relations. They worked together to handle labour disputes at the regional and district level.

The GTUC had no direct channel for reaching members in the regions and districts and therefore lacked a mobilising platform. This was compounded by the low for- 
mal educational background of members and leaders. Some executives of the councils of labour explained that union members required some level of formal education to understand the specialised nature of workers' and union concerns. Low trade union education resulted in scant appreciation of trade unions. Poor communication with the national headquarters in the absence of trade union education, compelled members to rely on the national media for information about their trade unions. This situation was cited as the cause of the failure of the GTUC to rally members against the illegal appropriation of workers' pension by the NPP government to fund the National Health Insurance Scheme in 2003 in its bid to win political favour100 (Britwum, 2007, pp. 57-59).

Poor working conditions of union officers and workers in general constituted another set of challenges identified by RCL and DCL executives. These problems dampened members' confidence in the GTUC causing general disinterest in union activities. Workers, they explained, were continually questioning the benefit of union membership. Poor working conditions of union executives served to increase the heavy costs of union meetings. Some workers saw union meetings as an occasion to earn extra income and others simply did not have the resources to fund travel to union meetings. Union executives said they were hampered in their work by union members who perceived union office as an avenue for personal gain. Such members blamed the inertia of the councils of labour to the misuse of union resources by RCL and DCL executives who were suspected of hoarding union resources for their personal benefit.

Councils of labour despite the absence of funding were functioning, through the mobilisation of local resources. The most dormant DCL could point out some level of activity that justified their continuing existence. The study investigated the forms of initiatives and strategies adopted to ensure the level of visibility which allowed active DCLs to conduct union activities despite the absence of GTUC funding. Most of the survival strategies revealed were directed at raising funds. The DCLs executives interviewed were exploring internal and external sources to find solution to their financial problems. The measures reported included cost cutting, membership levies, income generation and fundraising. Some had initiated schemes to get workers to volunteer to offer free services to their unions and convinced members not to expect refreshment and transport reimbursement for attending union meetings. Initiatives that looked to generate funding internally were those that were designed to levy workers and income generating ventures like acquiring a vehicle to serve a dual purpose; offer a means of transport for workers at a low price and raise funds for DCL activities. Others planned to secure bank loans and pay back with monies raised through membership levies. External funding sources identified included the Local Governments, the Metropolitan, Municipal, and District Assemblies

\footnotetext{
${ }^{100}$ Interview with STMCL leaders, May, 2008
} 
(MMDAs); then NGOs and donor agencies like BUSAC and ActionAid Ghana. External funding has to be supported by written proposals. DCL executives were doubtful that their proposal writing skills could meet the standards for funding. Different avenues were used by the councils of labour to solve perceived shortcomings and two reported accessing support from the Research and Policy Department of the GTUC with success. Two others had tried to use consultants and failed to secure funding and one DCL had used both with success. Some DCLs, were still waiting for outcome of funding proposals they had submitted. Others were unhappy about support from the GTUC secretariat to councils of labour in raising funds. Others expressed unease about external funding which they claimed were accompanied by demands that could compromise union autonomy in the districts. Local government funding for example, came with a price and some DCLs mentioned the expectation of MMDA Chief Executives that unions tow official line and refrain from publicly criticising government policy ${ }^{101}$.

Other strategies adopted to keep the DCLs active were networking with other labour movements especially the teachers' organ, the Ghana National Association of Teachers (GNAT), and advocacy NGOs like Integrated Social Development (ISODEC) and Third World Network. The local governments or the MMDAs were partners of the DCLs in the districts and some Chief Executives also provided the support. One of the most active DCLs reported close collaboration with the District Chief Executive whom they used to provide workers education on government policies. Their explanation was 'he is the head of municipality and workers' productivity assists the municipality. So when workers have peace then the Municipal Chief Executive is happy'. ${ }^{102}$ Here, union executives were making a direct connection between the workplace and the community in which they lived. The reliance on Chief Executives of MMDAs had implications for union activities however. This same DCL expressed misgivings about the expectations of the Chief Executive of the unconditional support of workers for government policies in his municipality and as was mentioned at one interview session, 'when the assembly funds projects some want to use it for their political agenda'103. In an election year (the period of data gathering), government support had the tendency to suggest leadership alliance with the ruling party and the DCL executives expressed their own discomfort with the collaboration even though they insisted that they were alert and could not be subject to manipulation.

On the whole however the DCLs devoted greater attention to solving financial problems under the assumption that most of their problems were created by the absence of funds. Their coping strategies were all directed at securing funding for

\footnotetext{
${ }^{101}$ Interview with YMCL executives, April, 2008.

102 Interviews with MMCL executives April, 2008.

${ }^{103}$ Interviews with STMCL executives May, 2008.
} 
union activities. The marked achievement pointed out was regular quarterly meetings where workers received some education on national and trade union policy as well as the Labour Act. Union executives in the regions and districts showed some level of enthusiasm for maintaining the GTUC structures in the conviction of the relevance to their working conditions. But they did not want to carry the sole responsibility for reviving the RCLs and DCLs. They insisted that the GTUC finds solutions. The next section examines the contents of the demands of RCL and DCL executives. It explores how union members use these structures to address their needs and concerns in the workplace and beyond.

\subsection{DEMANDS FOR RCLS AND DCL SURVIVAL}

Union executives had varying opinions about the future of RCLs and DCLs. Most were however certain of union survival and felt that current labour challenges demanded collective efforts on the part of workers. Such confident views were backed by convictions that the prevalence of worker exploitation in Ghana made union protection inevitable for workers in Ghana. Others saw benefit in union pluralism introduced by Act 651 and insisted that union leaders will be under pressure to secure the interests of their members better than they did under closed shop unionism. Union executives were certain that, despite the low levels of union education they complained of, the existence of a number of core union activists who had benefited from previous union education and were devoted to the union cause, will continue to work to secure the future of the RCLs and DCLs. Some however believed that the survival of the RCLs and DCLs was contingent on their relevance for workers and membership understanding of union relevance. There was worry that inactivity of councils of labour will deepen membership apathy and stifle union militancy. Several demands were made for reviving the regional and district councils of labour for the benefit of workers (Box 7.3).

Demands for ensuring survival of the councils of labour in the regions and districts as summarised in Box 7.3 showed a yearning for empowering individual union members and strengthening union structures. Top on the list of demands were calls for union education and capacity building for all members, and specialised training for leaders and regional union staff. The demands were supported by the belief that the educational attainment of Regional Secretaries and IROs should match that of management so they can command respect in their interactions at the workplace. This was considered particularly helpful for the profile of the trade unions. The desire for education was augmented by calls for union information which ranked second on the list of demands. 


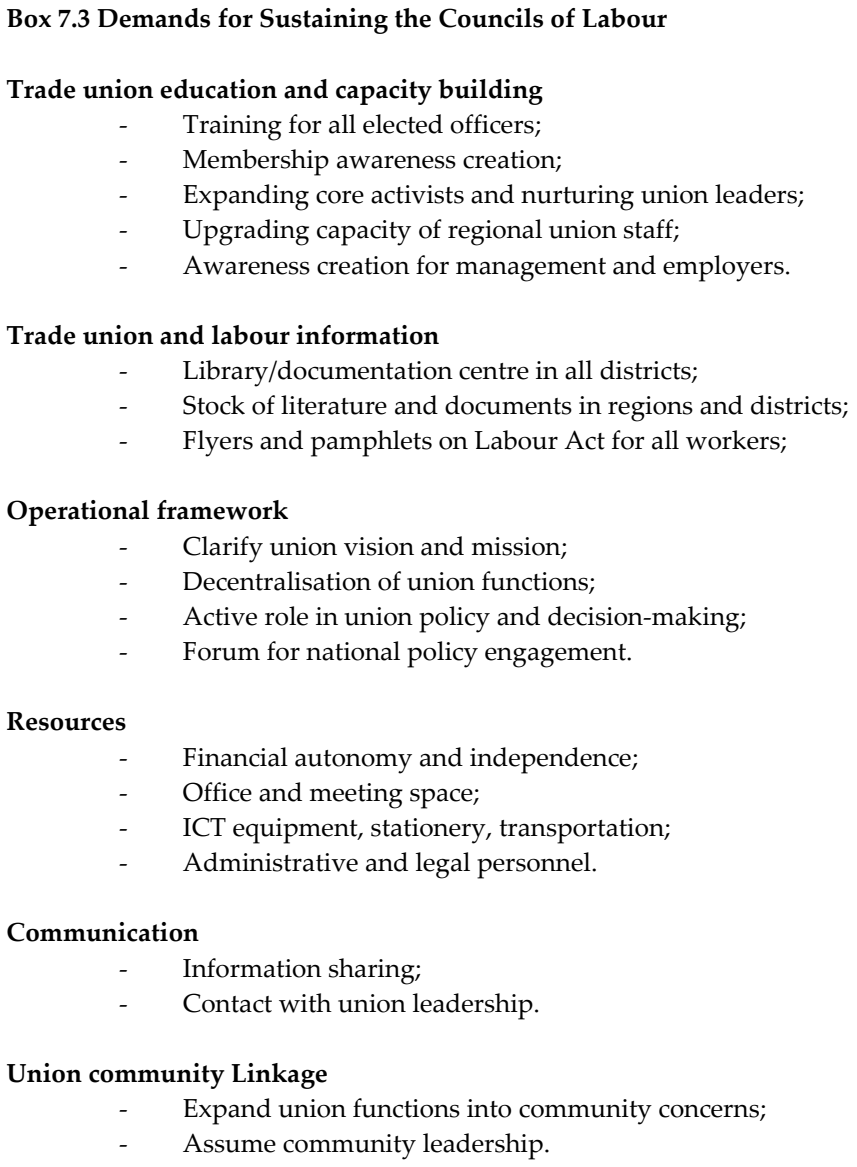

There were calls for the establishment of labour libraries or documentation centres in all regions and districts. Others asked for summaries of the Labour Act in pamphlets and on flyers for workers. This exercise had already been carried out by the GTUC and several such documents were distributed at DCL and RCLs meetings that were covered during the fieldwork. However, the numbers distributed covered only union executives who attended the meetings. Since DCLs had no offices there was no avenue to ensure that executives or ordinary union members who were not at the meetings could gain access to documents that were distributed. Which go to underscore the demands for a documentation centre to support the work of trade unionists and provide an avenue for self education for those who had the interest (Box 7.3).

Next on the list were demands that sought to expand the operational space of RCLs and DCLs within the GTUC structures. There were requests for the clarification of 
union vision and mission to give meaning to the regional and district structures, and decentralisation of union functions for greater autonomy in the districts and regions (Box 7.3). There was interest in using the DCLs and RCLs as a platform for playing an active role in the evolution of trade union policy and making contributions to union engagement with national policy.

The health and survival of the DCLs and RCLs were also concerns that the demands supported. Union executives interviewed wanted financial autonomy in the form of independent sourcing and management of funds as well as office and meeting space for all DCLs. There were in addition demands for an expansion in the space occupied by the RCLs, equipment and other logistics like transportation and administrative and legal personnel to reduce reliance on specialised union personnel located in Accra, the national capital. There was the feeling that union communication was poor, characterised by top down decision-making, with deficient contact between the national leadership and members. Some asked for the institution of a system for information sharing between all GTUC structures located in the districts, regions and national headquarters. Finally, union executives interviewed wanted the relevance of the union expanded beyond the workplace into the community. They insisted that to remain relevant the councils of labour will have to expand their functions into the communities in which they live and assume a leadership role in pursuing the concerns of their communities (Box 7.3).

The demands emphasize the realisation that strengthening the RCLs and DCLs was important for the pursuit of workers' interests. The demands recognised the various locations of union struggles in the workplace, in the union structures themselves and in the broader community. The demands revealed areas of inadequacy in relation to the capacity, knowledge and skills of union members and leaders, and also in relation to union credibility. Education was perceived as the most important instrument for correcting this inadequacy. Education in this light serves as a power tool for building leadership and membership capacity for engaging all union structures. Trade union education becomes an avenue for meaningful interactions between leaders their members. It also enhanced the ability of union leaders in regions and districts to engage with management or employers as well as state officials. Union education was presented as providing the foundation for creating the necessary awareness for strengthening members' sense of union ownership and building the solidarity base to assist organisation and mobilisation. The weak political connection between the RCLs and the national governing bodies and within the RCLs and DCLs was disempowering. The conceptualisation of the councils of labour as information dissemination platforms without responsibilities in the governance of the GTUC at the regional and district levels reduced their impact on union decisionmaking. The institutional placement of the RCLs and DCLs revealed some misperception of function whether as decision-making structures or information channels for leadership decisions. 
DCLs and RCLs derived varying levels of empowerment from clusters of union power tools located at the membership, union structure and processes. Available power tools for the DCLs and RCLs were the membership size, and location in the communities, members' sense of union relevance as well as DCLs as mobilising and solidarity building points. Communication and dialogue channels that the councils of labour provided for national leadership to reach the vast majority of union rankand-file members were also important power tools. By their location, the DCLs, especially, permitted the GTUC to connect and network with other labour movements, civil society and community groups. The presence and access to a specific power tool enables the DCLs and RCLs to be empowered thereby facilitating their access to greater participation in union processes. It is however not sufficient for a specific power tool to be available. It must be accessible. Disempowering factors were their conception, institutional location and resource incarceration. These blocked the utilisation of power tools like membership size and capacity, functioning as union decision-making and action points and silenced the voice of regional and district members in union policy making. Poor communication distanced members from leadership positions. The national bodies such as the Executive Board and the Executive Committees were left to operate as action points in the GTUC with little connection with members. The GTUC therefore, lost the occasion to take advantage of the contact with the general public through its membership structures, the RCLs and DCLs. This denied the confederation leadership the membership legitimating in the regions and districts.

\subsection{SUMMARY AND CONCLUSION}

The connection between internal and external democracy for trade unions underscores linking union pursuit of work place concerns and national policy. Union internal democracy in this light plays a pivotal role in facilitating union pursuit of workers' rights. The conclusion that unions and whatever they do border on democracy, whether internally or externally, draws attention to the pervasiveness of production relations and the ensuing associations that evolve in the national distribution of production benefits. The framework used in examining union democracy was directed at identifying union power tools for engaging union struggles in order to make the necessary connection between internal and external democracy. For it is in making the connection that one can discern the ability of union strategies to promote the needed renewal in the face of globalisation challenges. The approach used to examine the impact of union strategies can either consign unions to oligarchy or provide room to examine how they circumvent the precarious spaces of cooption, autonomy and influence to exercise sufficient power in the workplace and beyond to force concessions from employers and politicians to respond to their needs.

Even though union leaders have historically shown a tendency to be oligarchic, there are numerous examples of members' ability to reverse the trend and bring their leaders to order. Unions have played leading roles in recent efforts at institu- 
tionalising political pluralism. Unions as social economic players can straddle the interface between workplace and broader social and economic spaces. Such observations and conclusions make the conceptual underpinnings used to explore sources of union power, struggle sites and the connection between union life and national economic framework important.

The GTUC's attempts at revamping its regional and district consultative structures is directed by the need to increase membership participation in union activities and decision-making as a basis for enhancing internal democracy. The efforts have had limited success for several reasons. Even though the composition of the RCLs and DCLs and their executive councils replicate the GTUC national bodies like the Executive Committees, they do not wield the same power and authority in the regions and districts, as the national governing bodies. The positioning of the RCLs for example does not grant the same power over the Regional Secretariat that the Executive Board for example, has over the National Secretariat. As a political body the RCLs should however have some authority over the Regional Secretariat which should function to serve the needs of the RCLs and DCLs just as the National Secretariat serves the needs of the national policy making bodies. The authority of the Regional Secretaries, staff of the GTUC, over elected union officers is an anomaly in the union structures. As a representative organ union power should lie with elected officers in whom the members have reposed their trust. It is this principle that operates at the national level. The Secretary-General as an elected officer holds authority over the union administration. But the RCLs and DCLs are subservient to the Regional Secretariat and its head the GTUC Regional Secretary.

Because the RCLs and DCLs are conceived of as consultative structures they have no governing role in the GTUC. The conceptual and operational confusion about the role and authority of the RCLs and DCLs limits their autonomy and influence. The growth of the councils of labour and ability to make an impact in union agenda setting are also restricted as a result. This needs to be clarified for union members to derive power to engage their unions and secure greater internal democracy.

The RCLs and DCLs however hold considerable potential as mobilisation and solidarity points for the GTUC and their effective operation should offer the site for real union renewal. This is because of the power tools they hold in the form of membership aggregation, contact with the communities and strong sense of union relevance. The main power dynamics that is emerging is the tension between elected union leaders and union staff results from the conceptual confusion of the role of the councils of labour in union governance. Renewal strategies thus have to address the cession of real power and autonomy to these structures. The challenges of DCLs and RCLs were located in several spaces the most significant being the institutional lapses, capacity of members and leaders as well as financial and resource constraints. These challenges notwithstanding, DCLs and RCLs executives were confi- 
dent of their functional utility and empowering potential for union members in the regions and districts.

As noted earlier the RCLs and DCLs lie above the union locals within the GTUC hierarchy. Local unions are the sites where members engage daily in their productive activities. It is in their experiences within the relations of production at the enterprise level that arouse them to seek union membership and remain union members. Local unions also present sites of union relations that can also serve to facilitate or block members' pursuit of their interests and therefore have implications for union internal democracy. The next sections examine how local union leaders engage with higher union structures to secure the interests of workers they represent and the implications of this engagement for union internal democracy. 


\section{Chapter 8}

THE NATIONAL UNIONS AND THIER MEMBERS 


\title{
8 THE NATIONAL UNIONS AND THEIR MEMBERS
}

\begin{abstract}
The chapter focuses on union challenges at the enterprise level and factors determining union future. It outlines additionally how the constitutional location of the local unions facilitated access to power tools to back union strategies. The interrogation of workers' struggles site, target and content was based on the nature of workplace challenges and factors threatening union survival. The contents of workers' struggles were state policy, the parochial interests of management and politicians, their own capacity as unions and leadership commitment. These impacted employment security and by extension union existence as well as leadership commitment. Within the confines of the workplace, local executives recognised the importance of their unions and the potential of the national union coverage to expand union authority and influence. The limitation of membership entitlements to direct benefits and the constraining impact of constitutional provisions on the ability of locals to expand their voices and influence within union structures diminished the effectiveness of the power tools, sometimes making it necessary for them to seek the support of sources external to their unions.
\end{abstract}

\subsection{INTRODUCTION}

The previous chapter concluded that GTUC stands to achieve its goal of revamping DCLs and RCLs to increase membership participation in union activities and decision-making if only these structures are re-conceptualised as regional and district governing bodies and less as consultative structures. This chapter, as a sequel to Chapter Seven, explores how union structures at enterprise level provide avenues for members to pursue their interests in the workplace and beyond. Enterprise based unions form the basic structures of the national unions. As workplace structures, they hold the members that make up the unions and provide the financial backing of the national unions and GTUC in the form of dues deducted from their earnings. They are the union structure most present in the working life of workers, providing their first and major means of contact with their national unions. Enterprise based unions are the immediate union structures that workers fall on to draw power tools for the inevitable struggles that emerge in the context of their daily engagement with production. The operations of the enterprise based unions are important for pursuing the interests of union members. They legitimise unions by 
giving them a constituency. In short, without their locals, national unions would not exist. They are therefore the very essence of union existence.

Chapter Seven noted how the connection between internal and external democracy for trade unions revolves around the pervasiveness of production relations in all aspects of social and economic life. Globalisation has further fused the national and international political economic environments that shape the content and target of workers' struggles. The boundaries of the various sites of union struggles are blurred with the workplace space travelling into the union movement and the general society at large. Union role as provider of power tools for the pursuit and protection of workers' rights extends beyond the workplace into the social, economic and political arena. The availability of power tools therefore was insufficient to guarantee access and utilisation in the interest of union members. A mix of factors serves either to constrain or enhance access to tools that unions provide workers for pursuing their rights. The functions of the enterprise based unions which hold union members have been conceived as one such factor.

Among the critical challenges identified by national union leaders captured in Chapter Two were contact with members as well as members' perception of the utility and relevance of their unions. Improving union connection with members and expanding its relevance in their working lives were some of the renewal strategies adopted by national unions to retain their members in the face of trade union pluralism and management hostility. The interplay between union functions and activities can provide sufficient room for a meaningful engagement of workers with unions at the enterprise level. There was however limited information on the specific nature of these strategies and how national union organs were impacting membership structures. Union power tools available for workers to pursue their interests and how union structures and processes functioned in the working lives of members were important considerations that needed to be investigated. The role union members played in the formulation and realisation of power tools to contend with the challenges posed by capital and its representative, the nation state, also required interrogation.

This chapter examines the state of selected enterprise based unions of the six case study national unions, CBMWU, GAWU, GMWU, GPRTU, ICU and the MDU with information derived from field studies and union documents as outlined in Chapter 3. ${ }^{104}$ Other sources included Regional Industrial Relations Officers of the National Unions and the Regional Secretaries of the GTUC in the six selected regions. ${ }^{105}$ Officers of rival or splinter unions also provided information for the composition of this

\footnotetext{
104 See Appendix B, Tables 3 and 4 for a list of enterprise based unions covered by region and national union

105 See Chapter 3 for full details of data gathering methods and respondents covered.
} 
chapter. This chapter used the framework discussed in the previous one to examine how union internal democracy facilitates access to union power tools at the enterprise level. ${ }^{106}$ Most national unions label their enterprise based unions as local unions. Some national unions like the CBMWU, GMWU and MDU however designate their membership holding structures as branch unions. GAWU and GPRTU have branch unions that sit above the local unions. In this work the terms local unions or locals is used in place of enterprise based unions.

\subsection{LOCAL UNIONS' PROFILE}

Local unions covered in the study were drawn from several industrial locations under the usual public and private ownership structure (Table 8.1). The privately owned enterprises ranged from self-employment, the predominant form in the GPRTU, to Ghanaian and foreign owned concerns (Table 8.1)107. Foreign ownership was found mainly in manufacturing, construction, plantation agriculture and mining. Public enterprises in construction and agriculture were for the most part service provisioning organisations engaged in research, supervision or supporting other enterprises (Table 8.1).

The age of the local unions covered was related to the age of their enterprises. Public sector based unions were more likely to be older than the private sector ones. The GPRTU and GAWU provided the oldest unions and two locals covered in the study served as the nucleus around which the national unions developed. The age range of the local unions covered in the study reinforces the long union presence in Ghana. The oldest dated back to 1940s and the youngest was formed in 2007.

Table 8.1: Local Unions' Enterprise Base by Ownership and Industrial Location

\begin{tabular}{|l|l|c|c|c|c|c|}
\hline \multirow{2}{*}{ Base of Locals } & \multirow{2}{*}{$\begin{array}{l}\text { Industrial loca- } \\
\text { tion }\end{array}$} & \multicolumn{4}{|c|}{ Mode of ownership } & \multirow{2}{*}{ Total } \\
\cline { 2 - 6 } & Public & $\begin{array}{c}\text { Ghanaian } \\
\text { Private }\end{array}$ & $\begin{array}{c}\text { Self- } \\
\text { Employed }\end{array}$ & Foreign & \\
\hline CBMWU & Construction & 5 & 1 & - & 6 & 12 \\
\hline GAWU & Agriculture & 8 & - & - & 2 & 10 \\
\hline GMWU & Mining & 3 & - & - & 3 & 6 \\
\hline GPRTU & Road Transport & - & - & 11 & - & 11 \\
\hline \multirow{3}{*}{ ICU } & Manufacturing & 2 & 1 & - & 8 & 11 \\
\cline { 2 - 7 } & Finance & 3 & - & - & - & 3 \\
\cline { 2 - 7 } & Commerce & - & - & - & 2 & 2 \\
\cline { 2 - 7 } & Hospitality & 5 & 1 & - & - & 6 \\
\hline MDU & Marine transport & 2 & 4 & - & 1 & 7 \\
\hline Total & & 28 & 7 & 11 & 22 & 68 \\
\hline
\end{tabular}

Source: Fieldwork, 2008

\footnotetext{
106 See Chapter 7, Fig 7.1

${ }^{107}$ For the regional and district location of enterprises covered see Tables 3 and 4 of Appendix B
} 
The sex composition of the locals reflected the general male dominance in the GTUC. Most of the enterprises covered had female workforce proportions lower than $10 \%$. The highest was $43 \%$ and at two locals there were no female workers. The usual excuse of the nature of the work greeted field enquiries about low levels of female presence in the workforce. Public sector based unions had the highest female proportions. Female presence on local union executive structures was therefore low with most occupying the constitutional mandated reserved positions of women representatives. Senior staff unionisation was engaging some locals. In a few however, they had refused union coverage citing provisions in the Labour Act that barred certain categories of personnel from union membership as an excuse. Such locals resented their free rider status. Senior staff in mining and financial enterprises had a higher realisation of benefit of union membership. Senior staff unionisation as a result was on the increase within GMWU and ICU and to a lower degree among locals of GAWU and MDU. CBMWU reported the lowest instance of senior staff as members in the unions. GMWU and ICU had created special structures for their senior staff members and they were organised under the Professional and Managerial Staff Union (PMSU). The situation of GPRTU differed however, being a union of the self-employed, employment rank was differentiated by ownership of a vehicle. The question of senior staff membership therefore was not an issue for this national union.

Union fortunes in terms of membership potential were tied to the growth of the workforce. Workforce growth was in turn determined by enterprise fortunes, levels of technological advancement, rate of casualisation, use of contract workers and replacement workers lost by natural attrition. Casualisation was a peculiar feature within plantation agriculture, mining and construction industries, while the introduction of improved technology in manufacturing enterprises constrained workforce expansion. Public sector enterprises workforce growth was inhibited by the slow replacement of the workforce lost through retirement, resignation and death. The union membership size in the enterprises covered was unstable as a result, while some were fluctuating others had stalled; neither growing nor contracting. Where growth rate was high the recourse to temporal workers in the form of contract and casual workers hindered union growth. GPRTU however presented a different scenario by placing limits on membership expansion to regulate the road transport industry and ensure discipline. Admission into a GPRTU local union was subject to screening.

The motivation to form local unions came from various sources, some facilitated by legislation, specifically the Industrial Relations Act 299 (IRA, 299). The vast majority however were formed on workers' initiative; a few were established through the organisational drive of the national unions. GMWU locals were the most likely to be internally initiated, usually from repeated working rights abuses by management or as in the case of new construction enterprises on the instigation of workers with previous union membership. ICU had the highest number of national union initi- 
ated locals. GAWU, ICU and MDU locals based in the public sector benefited from the IRA 299. Private sector based locals were more likely to begin as house unions, workers' associations or councils, initiated by workers who realise the need for representation. They are later driven to seek stronger backing from established national unions when the local front of workers in the workplace proves inadequate for dealing with their employers. As the workers of a mining company explained during an interview session, 'we realised that the white employers were too strong for our association so we went to seek affiliation with GMWU'108. Workplace contradictions provided the necessary impetus for workers to organise and seek union coverage. In some instances construction workers who had previous experience of union membership were instrumental in the formation of local unions and pushing for affiliation with the national union, the CBMWU. The search for union affiliation is usually preceded by some investigations. Most will consult with the GTUC which will lead them to the national unions in whose jurisdiction they fall. One interesting instance which emerged during field study was the case of workers who took their search a step further by asking two potential national unions the ICU and PSWU for an introductory encounter with the entire workforce. The workers chose to join the ICU whose leadership they found convincing during the encounter.

The internal motivation in workplaces for union membership gives an indication of workers' awareness of the utility of unions pointing to a bright future for trade unionism in Ghana. Locals were aware of the potential of larger levels of union organisation to increase workers' power and enhance conditions for union survival. This fact served as motivation to seek national union affiliation. In addition workers felt empowered by the avenues to exit from national union affiliation should it prove unsatisfactory. Some forms of exit strategies in use that were identified included union fragmentation, switching national union affiliation. The provisions of the Labour Act, 651, 2003 that allowed labour pluralism was being utilised as an avenue for workers for better union representation.

\subsection{THE FUNCTIONING OF LOCAL UNIONS IN THE WORKPLACE}

The daily functions of locals constituted the contexts within which workers engaged their unions in the struggles to protect their interests. As a union organ located in the workplace, theirs was one of constant pressure to deliver and secure immediate response to workers' needs. In their daily functions they provided an outline of the scope of union operations, the targets of union struggles and power resources utilised to secure membership needs. Union functions are determined primarily by their constitutional provisions and it was within such spheres of activities that the locals operated. The discussions in this section therefore begin by looking at the

${ }^{108}$ Interview with local union leaders April, 2008 
constitutionally assigned roles of the local unions and then later give an overview of the practical daily activities of these locals at the workplace.

\subsubsection{The locals within union structures}

The constitutions of the national unions devolved power to the local unions over the workplace only. The constitutions placed the workplace based unions outside union governance structures. Table 8.2 below captures the constitutional role assigned the locals in terms of those that grant members autonomy to use their workplace unions without interference from their national unions and those that constrain membership action and subject them to the control of governing bodies or officers within the union hierarchy. GAWU's constitution makes a distinction between principal organs and 'other structures' of the union. The local unions fall under the 'other structures' (GAWU, 2008). The CBMWU makes such distinctions finer by separating governance bodies from administrative structures. The branch unions which constitute the lowest structure in union hierarchy, is considered an advisory body (CBMWU, 2000).

Union constitutions granted the locals autonomy to direct their operations and responsibility for functioning at the workplace. Locals had constitutional authority to elect their leaders as well as hold and manage their funds independently (see table 8.2). The levels of autonomy however differed within the national unions; GAWU, GMWU, GPRTU and ICU granted locals space to enact their own bye-laws, rules and regulations usually with caveat that it falls within the spirit of the national union constitutions. Locals that had bye-laws, rules and regulations in place used them to guide the operation of their welfare funds. This was the case of all locals of the GPRTU and in one instance of GAWU. The constitutions of the CBMWU, GMWU, and GPRTU assigned their locals responsibility to recruit and retain union membership. CBMWU also authorised its locals to create divisions and departmental units while in the case of GAWU, locals were tasked to coordinate the component units of their divisions. For the GMWU, and GPRTU who employ full time local union officers, the locals were mandated by their respective national union constitutions to determine the pay and working conditions of the staff and officers (Table 8.2). This level of autonomy helps to create independence and allows the executives of the locals to enhance their leadership skills. Autonomous roles empowered the locals within the limited confines of the workplace, but not as far as engaging their own unions at other levels, especially the national, and calling their national leaders to order (Table 8.2).

Local union autonomy however is countered by constitutional provisions that subject certain aspects of their functions to the approval of national or regional union leaders. Union activities are subjected to close scrutiny by governing organs especially the NEC. The constitutions of the national unions assigned overall supervisory responsibility of local unions to the NEC with the direct supervision either by the Regional Officers, the IROs or the body that falls above the local in union hierar- 
chy (Table 8.2). Though union funds are generated by the members of the locals out of the check-off deductions from their salaries, the management of these funds were subjected to heavy control by the National Officers of the national unions through the authority of the NEC and its supporting organs that govern the National Unions in between the QDC. The NECs and sometimes the General Secretaries, acting on behalf of the NEC, had ultimate control over local union funds in ways that rendered the members whose contributions had built the fund, powerless.

Table 8.2: Constitutional Role of Local Unions: Autonomy

\begin{tabular}{|c|c|c|}
\hline $\begin{array}{l}\text { Operational } \\
\text { limits }\end{array}$ & Details of constitutional roles & National Unions \\
\hline \multirow[t]{7}{*}{ Autonomy } & Adopt/draw up rules, regulations and bye-laws & $\begin{array}{l}\text { GAWU, GMWU, GPRTU, } \\
\text { ICU }\end{array}$ \\
\hline & Elect union officers & $\begin{array}{l}\text { CBMWU, GAWU, GMWU, } \\
\text { GPRTU, MDU }\end{array}$ \\
\hline & Organise social, educational and recreational activities & CBMWU, GMWU, GPRTU, \\
\hline & $\begin{array}{l}\text { Recruit union members } \\
\text { Sustain union membership }\end{array}$ & GMWU, CBMWU, GPRTU \\
\hline & $\begin{array}{l}\text { Create divisions and departmental units } \\
\text { Coordinate component units of locals/branch } \\
\text { Establish special committees }\end{array}$ & CBMWU, GAWU ,GMWU \\
\hline & Hold, manage and operate own union funds & $\begin{array}{l}\text { CBMWU, GAWU, GMWU, } \\
\text { GPRTU, MDU }\end{array}$ \\
\hline & $\begin{array}{l}\text { Draw up service conditions and salaries for staff and full } \\
\text { time officers }\end{array}$ & GMWU, GPRTU \\
\hline \multirow[t]{5}{*}{ Restriction } & $\begin{array}{l}\text { Bye-laws subject to approval of NEC, Regional Secretary, } \\
\text { Branch }\end{array}$ & GAWU, GMWU, GPRTU \\
\hline & $\begin{array}{l}\text { Submit reports to General Secretary, division, to NEC } \\
\text { through General Secretary } \\
\text { Carry out directives of National Secretariat, national } \\
\text { Union, General Secretary, NEC } \\
\text { Operate under the jurisdiction of a branch }\end{array}$ & $\begin{array}{l}\text { CBMWU, GAWU, GMWU, } \\
\text { GPRTU, MDU }\end{array}$ \\
\hline & $\begin{array}{l}\text { Manage union funds under supervision of NEC } \\
\text { NEC can take over functions of local executives } \\
\text { General Secretary on behalf of NEC have right to issue } \\
\text { guidelines for administering funds } \\
\text { Branch secretariat can probe use of funds and have final } \\
\text { control of funds } \\
\text { Subject to being taken over by branch for dues payment } \\
\text { default } \\
\text { Probe accounts and direct to proper use of funds }\end{array}$ & $\begin{array}{l}\text { CBMWU, } \\
\text { GAWU, } \\
\text { GMWU, } \\
\text { GPRTU, } \\
\text { ICU }\end{array}$ \\
\hline & Declare strike only with consent of NEC & GMWU \\
\hline & Send detailed list of members to national secretariat & ICU \\
\hline
\end{tabular}


Union government had been structured in ways that gave national officers control over union governance. The NECs assumed even large roles in the governance of the national unions and by extension the locals. In the particular instance of the locals and branch unions the General Secretary and their regional representatives, Regional IROs, assumed such roles on behalf of the NECs (Table 8.1). They were assigned responsibility for the rules and regulations developed by the locals, their activities and most importantly the management of their funds. Even though they were recognised as the structures holding union members, there was no constitutional provision for collecting views and concerns from the local unions to their national unions.

Union constitution placed more emphasis on the regulation of union processes less on facilitating representation and consultation. There was therefore no constitutional provision devolving power and control over union direction to the union members in the workplace. The membership of the governing bodies was dominated by the national officers elected at conferences. Local unions were limited to the workplace with no direct contact with the governing bodies of their unions. The system of consultation and renewal of leadership mandate by the members was largely non-existent; neither was there in place structures for facilitating effective representation. Union finances however played a large role in internal democracy. The collection and disbursement of funds were subjected to strict regulation under a specialised body, the finance committee. Authority over union finances by the governing body, the NEC offered direct control over the locals and served as a constraining factor. Finance also defined union membership and the corresponding entitlements of the member as a citizen of the union

\subsubsection{Local unions workplace functions}

Constitutional provisions, even though almost sacrosanct, exist on paper. It is in the daily happenings however, that the efficacy of such provisions are put to the test. The activities of local unions in the workplace were dictated by working conditions, workers' social and family welfare, work relations, and core union activities (Tables $8.3 \mathrm{a}, \mathrm{b}$ and $\mathrm{c}$ ). The range of activities engaging the attention of the locals differed among the national unions. It was largely determined by their industrial location, enterprise ownership structure and support from the national unions. GAWU, GMWU, ICU and MDU locals presented some similarities in terms of the range of activities that their local unions were engaged in.

The locals of national unions like GMWU were preoccupied with work conditions, negotiating and policing their Collective Bargaining Agreements (CBAs). Not only were locals interested in monitoring adherence, they were also interested in expanding the coverage of the CBAs to secure greater benefits in return for their productive efforts. GMWU local executives were in addition occupied with grievance handling 
and securing permanent employment for their members engaged as casuals (Table 8.3a).

Table 8.3a Local Union Functions: working conditions and workplace relations

\begin{tabular}{|c|c|c|}
\hline Functional Areas & Details of functions & National unions \\
\hline \multirow[t]{4}{*}{ Work conditions } & $\begin{array}{l}\text { Negotiate, monitor, expand and extend CBA benefits } \\
\text { Bridge gap in salary and benefit }\end{array}$ & $\begin{array}{l}\text { CBMWU, GAWU, } \\
\text { GMWU, ICU, MDU }\end{array}$ \\
\hline & $\begin{array}{l}\text { Protect workers' rights } \\
\text { Protection from arbitrary dismissals } \\
\text { Voice for members }\end{array}$ & $\begin{array}{l}\text { GAWU, GMWU, ICU, } \\
\text { GPRTU }\end{array}$ \\
\hline & Secure permanent employment & GMWU, CBMWU \\
\hline & Coordinate fare fixing & GPRTU \\
\hline \multirow[t]{4}{*}{ Workplace relations } & $\begin{array}{l}\text { Worker/management Intermediary } \\
\text { Channel workers' concerns } \\
\text { Workers' representative at management meetings }\end{array}$ & $\begin{array}{l}\text { CBMWU, GAWU, } \\
\text { GMWU, MDU }\end{array}$ \\
\hline & $\begin{array}{l}\text { Plant protection/productivity monitoring } \\
\text { Productivity consultations } \\
\text { Client/passenger support }\end{array}$ & $\begin{array}{l}\text { GAWU, GMWU, } \\
\text { GPRTU, ICU }\end{array}$ \\
\hline & $\begin{array}{l}\text { Workplace problems/Workplace discipline } \\
\text { Mitigate, mediate workplace sanctions } \\
\text { Complaints and grievances handling } \\
\text { Arbitration/Dispute mediation }\end{array}$ & $\begin{array}{l}\text { CBMWU, GAWU, } \\
\text { GMWU, ICU, MDU }\end{array}$ \\
\hline & $\begin{array}{l}\text { Coordinating work activities } \\
\text { Motivate workers }\end{array}$ & GPRTU, MDU \\
\hline
\end{tabular}

Source: Fieldwork, 2008

Local executives assumed an intervening role between management and workers. They were in some instances dealing with workplace discipline, maintaining good relations between workers and management or, in the case of GMWU, serving as communication channel for what was described as 'difficult management deci-

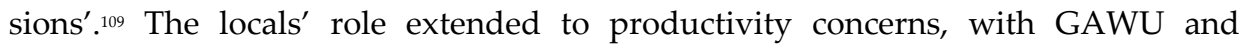
GMWU locals based in mining and plantation enterprises insisting that their functions covered plant protection and productivity monitoring because the well-being of workers and their unions was tied to the survival of the enterprise.

Beyond workplace local unions were involved in scheduled district/branch or regional union meetings. A few reported participating in the four yearly quadrennial delegates' conferences of their national unions and May Day parades as union activities undertaken beyond the scope of their locals. A few local executives held positions on the National Unions' decision-making bodies like the NEC (Table 8.3b). Such local union leaders functioned additionally as the only contact between the

\footnotetext{
${ }^{109}$ Interview with local union executives, May, 2008.
} 
workers and their national unions. As a result, they served as a channel for diffusion and implementing union policies $(8.3 \mathrm{~b})$

Educational activities featured among the functions of the local union executives of GAWU, GMWU, ICU, MDU and the GPRTU. Locals of the first three national unions organised trade union education for their members. The educational programmes covered workers' rights and responsibilities, usually within the ambit of the Labour Act. GAWU, GMWU and ICU locals were occupied with recruiting members and enhancing membership relations to secure the survival of their unions. Just like the executives of the Women's committees, local union executives were using their unions to solve problems beyond the workplace, like providing welfare to workers and attempting to shore up low incomes of members (Table $8.3 \mathrm{~b})$. GAWU locals, because of their location and interaction with their rural selfemployed members, were engaged in activities that offer support to farmers.

Table 8.3b Local Union Functions: Union activities

\begin{tabular}{|c|c|c|}
\hline Functional Areas & Details of functions & National unions Engaged \\
\hline \multirow[t]{4}{*}{ Union activities } & $\begin{array}{l}\text { Workers' contact with national union } \\
\text { Channel for national, regional union policies }\end{array}$ & CBMWU, GMWU, MDU \\
\hline & $\begin{array}{l}\text { Organising and attending: } \\
\text { Delegates conference/congress } \\
\text { Union regular and quarterly meetings } \\
\text { May Day celebrations }\end{array}$ & $\begin{array}{l}\text { CBMWU, GAWU, GMWU, } \\
\text { GPRTU, ICU and MDU }\end{array}$ \\
\hline & $\begin{array}{l}\text { Educational activities/seminars } \\
\text { Road safety education }\end{array}$ & $\begin{array}{l}\text { GAWU, GMWU, ICU, } \\
\text { MDU, GPRTU }\end{array}$ \\
\hline & $\begin{array}{l}\text { Investing union finances } \\
\text { Managing Union assets }\end{array}$ & GPRTU \\
\hline \multirow[t]{2}{*}{ Union survival } & $\begin{array}{l}\text { Membership recruitment } \\
\text { Union expansion }\end{array}$ & $\begin{array}{l}\text { GAWU, GMWU, ICU, } \\
\text { MDU }\end{array}$ \\
\hline & $\begin{array}{l}\text { Membership relations } \\
\text { Membership unity }\end{array}$ & $\begin{array}{l}\text { GAWU, GMWU, ICU, } \\
\text { MDU, GPRTU }\end{array}$ \\
\hline
\end{tabular}

Source: Fieldwork, 2008

The locals of the GPRTU covered in the study were engaged with enterprise survival and discipline was considered a key ingredient for attracting the travelling public in Ghana. The core concern of the GPRTU locals therefore was regulation for the smooth operation of the numerous vehicles for the passengers who use their services. The road sector was composed of numerous micro-enterprises made up of several individual owner and employee drivers. The number of enterprises that had to be managed was large, calling for a strict regulatory framework to avoid chaos. Small enterprise size also meant high livelihood vulnerability. The GPRTU's main preoccupation was an engagement with discipline and survival, calling for a system of regulation and welfare schemes that none of the other national unions could rival. The absence of regular incomes for most of their members denied the GPRTU 
the check-off system as an instrument for collecting dues. The collection of union dues, management and investment of union finances were therefore, key functions of the locals of the GPRTU (Table 8.3c). Locals were therefore preoccupied with investing union subscriptions in order to expand the welfare and servicing benefits they could extend to members. These included credit for vehicle repair and maintenance as well as loans to facilitate hire purchase of vehicles. Investments were mainly in the form of building structures that housed union offices and shops that were rented out to traders. In two of the six regions where field work was conducted, the Regional offices of the GTUC and the National Unions were in the structures owned by the Regional GPRTU offices ${ }^{110}$. The GPRTU locals were also concerned about social security, health insurance as well as accident benefits. They felt it was their obligation to organise coverage for their members (Table 8.3c).

Table 8.3c Local Union Functions: social welfare schemes and community relations

\begin{tabular}{|c|c|c|}
\hline Functional Areas & Details of functions & $\begin{array}{l}\text { National unions En- } \\
\text { gaged }\end{array}$ \\
\hline \multirow[t]{5}{*}{ Welfare and servicing } & $\begin{array}{l}\text { Credit/loan schemes } \\
\text { Hire purchase schemes } \\
\text { Income supplementation schemes }\end{array}$ & $\begin{array}{l}\text { GAWU, GMWU, } \\
\text { GPRTU, ICU }\end{array}$ \\
\hline & Credit access & GAWU, GMWU, GPRTU \\
\hline & $\begin{array}{l}\text { Social security and old age support schemes } \\
\text { Health and accident insurance } \\
\text { Unemployment } \\
\text { Legal support }\end{array}$ & GPRTU, \\
\hline & $\begin{array}{l}\text { Social and welfare schemes } \\
\text { Funeral, ill health and family support }\end{array}$ & $\begin{array}{l}\text { GMWU, GPRTU, ICU, } \\
\text { MDU, }\end{array}$ \\
\hline & On the job-training & ICU, GPRTU \\
\hline Community Relations & Farmer support & GAWU \\
\hline
\end{tabular}

Source: Fieldwork, 2008

GPRTU locals who had been able to secure such facilities presented their achievements with pride. The locals who had no such facilities, quoted the example of those who had, as a standard they were working to. Welfare funds were a feature of all locals of the GPRTU covered in the study. Each local had their own bye-laws covering the operations of their welfare fund. Some locals of CBMWU, GAWU, ICU and MDU had in place welfare schemes similar to those of the GPRTU, though not as extensive. The welfare schemes were supported by welfare funds that were either used to provide funeral contributions for bereaved members (CBMWU, ICU and MDU) or offer credit facilities (GAWU).

\footnotetext{
110 The offices Central and Ashanti Regional Secretariats of the GTUC were located in the Regional offices of the GPRTU in the respective regions.
} 
The locals of the GPTRU operated like trade associations, acting as a voice for members, making the survival and growth of the businesses of their members a principal concern. The striking discovery was that union membership extended beyond the working life of its members and that a loss of job and income did not deny one membership in GPRTU. Membership subscriptions therefore provided security for unemployment, ill-health, retirement and benefit to survivors. Union income beyond subscriptions paid by members was therefore very important. GPRTU members, as a result, evaluated their locals in terms of the support they provided their members' enterprises and the financial benefits that members earned from their membership of the union.

The locals of the CBMWU presented the least variety of union workplace functions. Acting as an intermediary between workers and management appeared to occupy union executives' time in the workplaces. This could be the result of workers' low educational background or highly insecure work conditions in the construction industry. There was also some preoccupation with workplace discipline, boosting workers' morale and mediating harsh sanctions imposed on workers who flout workplace rules, usually through absenteeism or petty thieving. Interaction with their national union was low and limited to contact between the workers and their regional officers and, in some rare instances, the national union. The main functions of CBMWU locals revolved around working conditions, collective bargaining negotiations, monitoring and interpretation as well as worker management relations.

The functions of the local unions were limited to the workplace. It consisted in pursuing membership concerns and protecting their rights as workers. Their engagement with the national unions was rather limited. Few engaged with their national unions beyond branch, district or regional meetings. The executives of local unions reinforced the importance of their unions for engaging workplace based struggles and for providing solutions to their employment related problems. They also recognised the limitations and insisted that workplace based unions, even though important, were just the first step in the process of mobilising workers' collective strength for their protection. Affiliation to national based unions was considered instrumental in adding to the authority and influence of locals. It was for this reason that they sought integration into national unions and confederations.

\subsection{THE CONTENT AND TARGET OF WORKPLACE STRUGGLES}

The effectiveness of the local unions is revealed in the manner in which they help to address the peculiar challenges of workers. Workplace challenges in this section are used as a measure of workers' struggles. By extension, the origins of the challenges are held as the targets of their struggles while the nature of the challenges is considered the content of these struggles. In a later section the discussion on coping strategies is used as a measure of the sources and content of power tools for meeting union challenges. 


\subsubsection{Local union workplace struggles}

Government policy environment and the political interests of the ruling politicians were identified by local union executives as the context challenging the substance of their workplace existence (Table 8.4a). State policy in the form of privatisation, withdrawal of subsidies for public enterprises, deregulation, liberalised trade, high import tariffs and tax regimes were cited as being detrimental to enterprise growth. Local union executives were concerned that such policies undermined their employment and income security as well as employment rights (Table 8.4a). State policies set the environment for enterprise viability and impacted the legislative setting for upholding workers' rights. Locals of GPRTU were more concerned with policy ambiguity that produced a hostile environment for their operations like local government's city beautification or decongestion exercises that criminalised their use of space for the pursuit of their livelihoods.

Local executives also identified political interference arising out of the rent seeking interests of ruling political leadership as the main factor undermining the growth of the enterprises in which they worked. Allegations of political interference though, were high. Union executives complained of frequent changes in management as the bane of their enterprises. In their estimation, such frequent managerial changes were informed more by political patronage and less by the personal competence of the officers involved (Table $8.4 \mathrm{~b}$ ).

Table 8.4a Workers' Challenges: Politics, Policy Direction and Future of Industry

\begin{tabular}{|c|c|c|c|}
\hline Source & Content & Underlying Issues & $\begin{array}{l}\text { National Union } \\
\text { base of locals }\end{array}$ \\
\hline \multirow[t]{2}{*}{$\begin{array}{l}\text { Government; } \\
\text { policies, insti- } \\
\text { tutions and } \\
\text { legal frame- } \\
\text { work }\end{array}$} & $\begin{array}{l}\text { Liberalisation and } \\
\text { deregulation policies }\end{array}$ & $\begin{array}{l}\text { - Minimum wage fixing } \\
\text { - Privatisation } \\
\text { - Deregulation } \\
\text { - Policy ambiguity and exclusion } \\
\text { - Repressive laws } \\
\text { - Casualisation } \\
\text { - Liberalisation }\end{array}$ & $\begin{array}{l}\text { CBMWU } \\
\text { GAWU } \\
\text { GMWU } \\
\text { GPRTU } \\
\text { ICU } \\
\text { MDU }\end{array}$ \\
\hline & $\begin{array}{l}\text { Unfair competition } \\
\text { Low productivity } \\
\text { Cost cutting measures }\end{array}$ & $\begin{array}{l}\text { - High tax regimes } \\
\text { - Proliferation of foreign enterprises } \\
\text { - Poor utilisation of workers } \\
\text { - } \text { Mergers, downsizing } \\
\text { - Unfair competition, } \\
\text { - Poor infrastructure } \\
\text { - Police harassment } \\
\text { - Absence of raw materials } \\
\text { - } \text { Labour intensive technology }\end{array}$ & $\begin{array}{l}\text { CBMWU } \\
\text { GAWU } \\
\text { GMWU } \\
\text { GPRTU } \\
\text { ICU } \\
\text { MDU }\end{array}$ \\
\hline $\begin{array}{l}\text { Political inter- } \\
\text { ference }\end{array}$ & $\begin{array}{l}\text { Political Manipulation } \\
\text { Cooptation }\end{array}$ & $\begin{array}{l}\text { - Political manipulation of divestiture } \\
\text { - Lack of transparency in mergers and } \\
\text { acquisitions } \\
\text { - } \text { Rent-seeking and patronage } \\
\text { - Frequent management changes } \\
\text { - Cooption and manipulation of union } \\
\text { leaders }\end{array}$ & $\begin{array}{l}\text { GAWU } \\
\text { GMWU } \\
\text { GPRTU } \\
\text { ICU } \\
\text { MDU }\end{array}$ \\
\hline
\end{tabular}

Source: field data, 2008. 
The fate of decaying public enterprises located in the mining, agriculture and manufacturing sectors were attributed to decisions about their future which, according to the local executives, was informed more by self-seeking interests of politicians. Local executives in such enterprises were certain that but for political interests their companies would have been revived through state re-capitalisation or offloading to interested foreign companies. What was important for the study was not the veracity of their claims but the fact that workers harboured such claims. The fate of such enterprises in the face of their potential and an absence of any explanation for the mediocre performance, gave fuel to such accusations from workers.

The challenges faced by the locals in the workplaces were shaped largely by their industrial location and mode of enterprise ownership. Private sector based local unions were concerned about employment conditions like their welfare in the workplace and the quantum of benefits derived from their effort in wealth creation. Livelihood security for locals based in public enterprises and for the self-employed took precedence over the benefits derived from their productive efforts. Government policies provided the broader framework for enterprise survival. Management attitude and personal interests were in addition identified as undermining enterprise survival (Table $8.4 b$ ).

Table 8.4b Workers' Challenges: Management capacity and Hostility to Union

\begin{tabular}{|c|c|c|c|}
\hline Source & Content & Underlying Issues & $\begin{array}{l}\text { National } \\
\text { union base of } \\
\text { locals }\end{array}$ \\
\hline $\begin{array}{l}\text { Management } \\
\text { capacity and } \\
\text { commitment }\end{array}$ & $\begin{array}{l}\text { Kleptocracy } \\
\text { Rent seeking }\end{array}$ & $\begin{array}{l}\text { - Low commitment of management to enterprise } \\
\text { survival } \\
\text { - } \text { Rent seeking/Self seeking Ghanaian management } \\
\text { - } \text { Absence of management accountability structures } \\
\text { - } \text { Management ignorance of labour laws } \\
\text { - } \\
\text { - } \\
\text { - }\end{array}$ & $\begin{array}{l}\text { CBMWU } \\
\text { GAWU } \\
\text { GMWU } \\
\text { ICU }\end{array}$ \\
\hline Union hostility & $\begin{array}{l}\text { Union bursting } \\
\text { techniques }\end{array}$ & 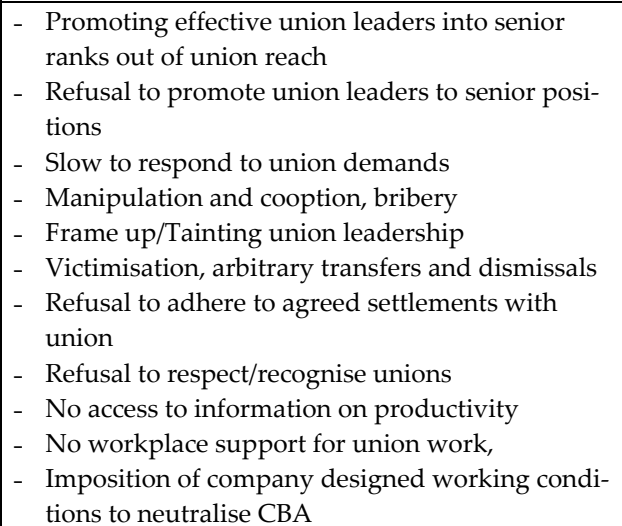 & $\begin{array}{l}\text { CBMWU } \\
\text { GAWU } \\
\text { GMWU } \\
\text { ICU } \\
\text { MDU }\end{array}$ \\
\hline
\end{tabular}


Ghanaian and Asian management cut a poor image in the estimation of local union executives in plantation agriculture for GAWU and manufacturing for ICU. In the view of the locals of public enterprises, it was the motives of their Ghanaian management that undermined enterprise viability, while in privately owned companies it was Ghanaian management's avowed hostility to unions that constituted a threat to union survival. Chinese and Indian employers, workers claimed, operated under such levels of minimalist policies as to undercut to the extreme all benefits to workers. Visits to three such manufacturing companies showed decayed physical infrastructure and compound overgrown with weeds and poor drainage. The external environment gave one little basis to dispute workers' narration of poor health and safety conditions within the plant where they worked. Workers located in public owned manufacturing enterprises were usually concerned with kleptocratic practices of management. Public service enterprises however, escaped such accusations.

Workers were also critical of Ghanaian management in foreign owned companies which they identified as repressive and exhibiting greater hostility to workers and their unions. The union bursting techniques reported included victimisation of local union leaders, arbitrary transfers and dismissals as well as verbal assaults (Table $8.4 \mathrm{~b})$. Union leaders reported instances of being sidelined for promotion. Management response to such accusations was that the commitment of union leaders to their workplace responsibilities was affected by their positions and as such they usually failed to meet the requirements for promotion. Other instances reported the use of promotion as a bait to co-opt or silence union leaders. Vocal union leaders are sometimes promoted to senior level positions that the Labour Act has barred from union membership thus taking them out of union jurisdiction. Local union executives also reported instances where vocal and effective union leaders have resigned their positions only to be promoted later to senior positions (Table 8.4b). Such occurrences have served to demoralise workers and the remaining executives. In privately owned foreign enterprises, workers were confronted with minimalist cost reduction policies of employers. These policies affected wages and salaries, health and safety conditions, and additionally job security.

Conditions of employment, social security and the impact of working environment on workers' health were the main employment related concerns that were reported as engaging local unions in the workplace (Table $8.4 \mathrm{c}$ ). The specific concerns were workers welfare and their ability to derive fair benefits in return for their productive efforts. CBAs were the main instruments that locals employed to protect their employment rights. The content and process of securing CBAs were therefore a major preoccupation for locals with that facility. Other concerns were the grading and promotion procedures, salary and employment security as well as on-the-job training and development (Table 8.4c). 
Table 8.4c Workers' Challenges: Employment Conditions and Social Security

\begin{tabular}{|c|c|c|c|}
\hline Source & Content & Underlying Issues & $\begin{array}{l}\text { National union base } \\
\text { of locals }\end{array}$ \\
\hline $\begin{array}{l}\text { Conditions of } \\
\text { Employment }\end{array}$ & $\begin{array}{l}\text { CBAs } \\
\text { Grading, Promo- } \\
\text { tion } \\
\text { Employment } \\
\text { benefits }\end{array}$ & $\begin{array}{l}\text { - CBA delays and flouting of provisions } \\
\text { - Delayed promotion/Ambiguous grad- } \\
\text { ing system } \\
\text { - } \text { Rank compression and delayed promo- } \\
\text { tions } \\
\text { - } \text { Unclear/degraded conditions of service } \\
\text { - } \quad \text { Low salaries/ Irregular salaries } \\
\text { - } \text { Inadequate working tools } \\
\text { - Employment and income insecurity } \\
\text { - } \text { Discriminatory employment benefits } \\
\text { and salaries } \\
\text { - No facilities for training and personal } \\
\text { development } \\
\text { - Slow grievance process } \\
\text { - Inconvenient/demanding work } \\
\text { hours/schedule }\end{array}$ & $\begin{array}{l}\text { GAWU } \\
\text { GMWU } \\
\text { GPRTU } \\
\text { ICU } \\
\text { MDU }\end{array}$ \\
\hline $\begin{array}{l}\text { Workers' } \\
\text { morale }\end{array}$ & $\begin{array}{l}\text { Attitude and } \\
\text { commitment to } \\
\text { work }\end{array}$ & $\begin{array}{l}\text { - High turnover, lateness and absentee- } \\
\text { ism } \\
\text { - low productivity/Low morale } \\
\text { - Stressful/dehumanising working condi- } \\
\text { tions } \\
\text { - No respect/appreciation for workers' } \\
\text { contribution to enterprise }\end{array}$ & $\begin{array}{l}\text { CBMWU } \\
\text { GAWU } \\
\text { GMWU } \\
\text { GPRTU } \\
\text { ICU } \\
\text { MDU }\end{array}$ \\
\hline Social security & $\begin{array}{l}\text { Social security } \\
\text { Pension retirement }\end{array}$ & $\begin{array}{l}\text { - No social security/pension scheme } \\
\text { - No health insurance } \\
\text { - No injury compensation } \\
\text { - No retirement benefits, no provident } \\
\text { fund } \\
\text { - No retirement package and long service } \\
\text { awards } \\
\text { - Failure to pay SSNIT and provident } \\
\text { fund deductions } \\
\text { - Low social/welfare support }\end{array}$ & $\begin{array}{l}\text { CBMWU } \\
\text { GAWU } \\
\text { GMWU } \\
\text { GPRTU } \\
\text { ICU } \\
\text { MDU }\end{array}$ \\
\hline $\begin{array}{l}\text { Health and } \\
\text { safety }\end{array}$ & Safety at work & $\begin{array}{l}\text { - Poor OHS observance } \\
\text { - No personal protective equipment } \\
\text { - } \text { Threat from frustrated community } \\
\text { members } \\
\text { - Unsafe unhygienic working Environ- } \\
\text { ment } \\
\text { - No on-site first aid or medical facilities } \\
\text { - Obsolete working equipment }\end{array}$ & $\begin{array}{l}\text { CBMWU } \\
\text { GAWU } \\
\text { GMWU } \\
\text { GPRTU } \\
\text { ICU } \\
\text { MDU }\end{array}$ \\
\hline
\end{tabular}

Source: fieldwork, 2008

Concerns extended to disparities in income and employment benefits especially for GAWU, ICU and GMWU based locals and, as union leaders explained, 'high levels of discrimination and disparities in employment benefits breed disaffection among 
workers'. ${ }^{111}$ Their social security also posed a source of concern, not the least being the presence and range of facilities that secure workers' access to income beyond their capacity to work, injury compensation and the management of social security benefits. Two locals complained about their companies' failure to submit deductions for social security. Failure of one employer to pay the deductions was brought to the notice of local union executives when officials of the bank responsible for managing the provident fund came to make enquiries about fall-back on payments.

\footnotetext{
'The company owes the bank Gh $\$ 150 \mathrm{~m}^{112}$ in terms unpaid provident fund deductions and there are no statements of account showing how much has been deducted from workers so when workers are going on retirement employers workout some arbitrary figures and pay the retiring workers' ${ }^{\prime 113}$
}

In the case of the second enterprise a worker's attempt to access his social security benefits on retirement from the public pension scheme manager the Social Security and National Insurance Trust (SSNIT) exposed management failure to pay deductions. A follow up interview with the regional officer of the national union that the executives belonged explained that SSNIT was in the process of prosecuting the enterprise and that workers will not suffer loss of their pension entitlements since there existed proof of deductions. The local executives in these enterprises were sceptical of such assurances and the administration of their social security entitlements remained one of their core concerns. Politics, policy direction, management capacity and attitude to unions as well as employment conditions were the main challenges of locals emanating from outside union confines. Other challenges however originated from within the local or national unions.

Locals struggled against their national and local unions (See Tables 8.4d and 8.4e). There were reports of problems with union leadership, accountability and enforcing union membership. One local complained about the failure of their national union to ensure that the state institutions responsible for public service pay-roll effected the check-off deductions of dues from their salaries (Table 8.4d). Leadership financial accountability was also a source of concern for locals especially within the GPRTU where membership subscriptions were used to provide social security and credit support for members.

The locals struggled with their capacity to build strong viable unions at the workplace that could survive attack from their employers and management (Table 8.4e). The content of these struggles were related to membership cohesion and union ownership, trade union education for members as well as the resource base for operating the unions. Local executives were engaged in securing members' confidence

\footnotetext{
${ }^{111}$ Interview with local union executives, March, 2008.

112 At the time of data gathering Ghana $\$ 1.00$ was equivalent to US $\$ 1.00$

113 Interview with local union executives, May, 2008
} 
and reported instances where members showed lack of confidence. Partisan politics and management cooption were some factors named as dividing the rank of union members and driving a wedge among union leaders. Intra union unity was further threatened by membership capacity and poor communication between leaders and members. Ignorance about the Labour Act and union functions was cited as factors that affected their conception of union functions and in this case members' perception of union relevance and effectiveness. For example any failure on the part of local executives to prevent the sanctioning of defaulting workers who flout work rules was interpreted as union weakness. Local executives were continuously challenged to prove to members that unions were relevant and had the capacity to live up to workers' expectations. Such expectations had to be managed to fit into the sphere of union functions.

Table 8.4d Workers' Challenges: National leadership capacity and commitment

\begin{tabular}{|c|c|c|c|}
\hline Source & Content & Underlying Issues & $\begin{array}{l}\text { National union } \\
\text { base of locals }\end{array}$ \\
\hline Local Leadership & $\begin{array}{l}\text { Local union } \\
\text { leadership } \\
\text { structure and } \\
\text { capacity }\end{array}$ & $\begin{array}{l}\text { - } \text { Absence of trade union education } \\
\text { - } \text { Refusal to fill national leadership gaps } \\
\text { - } \text { Ineffective/failed union leadership, } \\
\text { - } \text { High union leadership turn over } \\
\text { - } \quad \text { Low formal educational background of } \\
\text { regional and national leadership } \\
\text { - } \\
\text { - }\end{array}$ & $\begin{array}{l}\text { CBMWU } \\
\text { GAWU } \\
\text { GMWU } \\
\text { GPRTU } \\
\text { ICU } \\
\text { MDU }\end{array}$ \\
\hline $\begin{array}{l}\text { National leader- } \\
\text { ship }\end{array}$ & $\begin{array}{l}\text { Response to } \\
\text { union con- } \\
\text { cerns } \\
\text { Leadership } \\
\text { value system } \\
\text { and union } \\
\text { interests }\end{array}$ & $\begin{array}{ll}\text { - } & \text { National leadership slow to respond to } \\
& \text { local union concerns } \\
\text { - } & \text { Self-seeking leaders } \\
\text { - } & \text { Leadership manipulation of local leader- } \\
\text { ship } & \\
\text { - } & \text { Victimisation of local leaders by national } \\
& \text { leader } \\
\text { - } & \text { Members lack of confidence in national } \\
& \text { leaders commitment to union cause } \\
\text { - } & \text { Power struggle among leaders } \\
\text { - Self seeking leaders } \\
\text { - } \text { Leaders/membership gap } \\
\text { - Incompetent Regional officer } \\
\text { - Slow response of National leaders to mem- } \\
\text { bers concerns } \\
\text { - Members frustrated \& suspicious of leaders } \\
\text { - No union/membership dialogue } \\
\text { - Exploitative Union-manager } \\
\text { - Conflict of interest: union as employer and } \\
\text { representative }\end{array}$ & $\begin{array}{l}\text { CBMWU } \\
\text { GAWU } \\
\text { GMWU } \\
\text { GPRTU } \\
\text { ICU } \\
\text { MDU }\end{array}$ \\
\hline
\end{tabular}

Source: field data, 2008 
Table 8.4e Workers' Challenges: Local Union capacity, relevance and effectiveness

\begin{tabular}{|c|c|c|c|}
\hline Source & Content & Underlying Issues & $\begin{array}{l}\text { National } \\
\text { union base of } \\
\text { locals }\end{array}$ \\
\hline $\begin{array}{l}\text { Membership } \\
\text { relation intra } \\
\text { union unity }\end{array}$ & $\begin{array}{l}\text { Union cohesion } \\
\text { Union owner- } \\
\text { ship }\end{array}$ & $\begin{array}{l}\text { - Membership limited interest in salary matters } \\
\text { - } \text { Membership distrust for union leaders } \\
\text { - Nature of work space/time affects union meet- } \\
\text { ings } \\
\text { - } \text { Members demands for local union dues to sup- } \\
\text { plement low incomes } \\
\text { - } \text { Free rider status of senior staff } \\
\text { - } \text { Local leadership disunity } \\
\text { - Partisan political affiliation creating membership } \\
\text { disunity } \\
\text { - Cooptation and manipulation of workers } \\
\text { - Absence of confidentiality undermines leader- } \\
\text { - } \text { ship unity } \\
\text { - } \text { Pack of support/confidence for local leadership } \\
\text { tion } \\
\text { - Absence of intra union consultation }\end{array}$ & $\begin{array}{l}\text { GAWU } \\
\text { GMWU } \\
\text { GPRTU } \\
\text { ICU } \\
\text { MDU }\end{array}$ \\
\hline $\begin{array}{l}\text { Membership } \\
\text { capacity }\end{array}$ & $\begin{array}{l}\text { Trade union } \\
\text { education } \\
\text { Formal educa- } \\
\text { tional back- } \\
\text { ground }\end{array}$ & $\begin{array}{l}\text { - Absence of trade union education } \\
\text { - Ignorance of Labour Act, CBA, workplace rules } \\
\text { and regulations } \\
\text { - Declining membership } \\
\text { - Confusion about union role and function } \\
\text { - Low formal educational background } \\
\text { - Absence of workplace training and development } \\
\text { facilities }\end{array}$ & $\begin{array}{l}\text { CBMWU } \\
\text { GAWU } \\
\text { GMWU } \\
\text { GPRTU } \\
\text { ICU } \\
\text { MDU }\end{array}$ \\
\hline $\begin{array}{l}\text { Union Rele- } \\
\text { vance and } \\
\text { effectiveness }\end{array}$ & $\begin{array}{l}\text { Union presences } \\
\text { and effective- } \\
\text { ness in the } \\
\text { workplace }\end{array}$ & $\begin{array}{l}\text { - Union less effective than in the past so desire to } \\
\text { join new labour centres } \\
\text { - Discrimination by GTUC more attention to } \\
\text { workers with CBA than civil service } \\
\text { - No support for aged members } \\
\text { - Membership apathy } \\
\text { - Distance from national union } \\
\text { - Weak ineffective local union }\end{array}$ & $\begin{array}{l}\text { CBMWU } \\
\text { GAWU } \\
\text { GMWU } \\
\text { GPRTU } \\
\text { ICU } \\
\text { MDU }\end{array}$ \\
\hline $\begin{array}{l}\text { Union finances, } \\
\text { resources }\end{array}$ & $\begin{array}{l}\text { Financial man- } \\
\text { agement and } \\
\text { accountability }\end{array}$ & $\begin{array}{l}\text { - } \text { Low subscriptions } \\
\text { - } \text { Refusal to deduct union dues } \\
\text { - } \text { Failure to transfer local union allocation of dues } \\
\text { - } \text { Failure to enforce deduction of dues } \\
\text { - High levels of deductions } \\
\text { - } \text { Dwindling union financial base } \\
\text { - National union failure to transfer local union } \\
\text { - allocations } \\
\text { - Absence of space and facilities for local union } \\
\text { - } \text { operations }\end{array}$ & $\begin{array}{l}\text { CBMWU } \\
\text { GAWU } \\
\text { GMWU } \\
\text { GPRTU } \\
\text { ICU }\end{array}$ \\
\hline
\end{tabular}


Workers' struggles for representation to defend their rights point to the sites and targets of their struggles. It appears that union size and influence increases along with the sites of struggle. The desire at the workplace to secure locals in bigger more established trade unions is in reference to the recognition that the capacity to engage targets of their struggle is strengthened with higher levels of representation beyond the workplace.

\subsubsection{Determinants of union future}

A second indicator used to determine sites and targets of union struggles was local union executives' predictions about union future and factors they identified as being responsible for shaping union future. Their summarised responses are presented in Tables 8.5a, b, c, d, e and $\mathrm{f}$ according to their national union affiliations. The level of despondency characterising local executives' assessment of their national unions during interviews was striking considering that these locals had been purposely selected by the IROs of the national unions. Some of the criticisms were expressed in the presence of the union field officers and local union leaders did not spare their officers in their choice of words to express their opinions.

Expressions of optimism for union future were limited to the workplace local unions. The local executives were hesitant to extend similar levels of optimism to the national unions and the union confederation, the GTUC. Locals most optimistic about their union future were more likely to be located in the GMWU (Table 8.5a) and least in the MDU or CBMWU (Tables 8.5e and f). These last two unions presented interesting field work cases that have been covered in this section. Determinants of union future identified were either located in the national policy making arena, management competence and commitment, as well as union leadership capacity and devotion to the union cause.

GMWU local executives' optimism for union future was based on the rapid expansion of PMSU membership in mining enterprises. The PMSU members drawn from senior staff of the various enterprises, it was explained, boost union membership capacity and swell union income because of their higher formal educational background and salary levels (Table 8.5a). Locals were investing in membership education and supporting foreign travel for union executives towards enhancing their leadership capacity. Local executives of GMWU also commended the existing communication between union structures at the branch and national levels as a strong foundation for union survival. Other determinants that were supposed to boost union future were the prospects of the mining enterprise itself and the shift by some corporations to invest in underground mining. But the local executives were unsure about the national union leaders' commitment and recommended some efforts to be invested in securing membership confidence. 
Table 8.5a GMWU Locals Assessment of Union Future

\begin{tabular}{|c|c|c|c|}
\hline Conditions & Bright future & Uncertain future & Bleak future \\
\hline $\begin{array}{l}\text { Union relevance/ pres- } \\
\text { ence }\end{array}$ & $\begin{array}{l}\text { Good intra-union com- } \\
\text { munication policy }\end{array}$ & & \\
\hline Membership expansion & $\begin{array}{l}\text { PMSU expansion boost } \\
\text { membership size } \\
\text { Support to small scale } \\
\text { miners }\end{array}$ & & \\
\hline Leadership commitment & & $\begin{array}{l}\text { Leaders ability to gain } \\
\text { members' confidence }\end{array}$ & \\
\hline Leadership capacity & $\begin{array}{l}\text { PMSU boost union } \\
\text { capacity and income } \\
\text { Leadership education } \\
\text { and exposure }\end{array}$ & & \\
\hline $\begin{array}{l}\text { Management style, } \\
\text { capacity, and commit- } \\
\text { ment }\end{array}$ & & & $\begin{array}{l}\text { Hostile management } \\
\text { Manipulation and } \\
\text { cooptation of union } \\
\text { leadership }\end{array}$ \\
\hline Union hostility & & & $\begin{array}{l}\text { Insecurity among local } \\
\text { union leaders }\end{array}$ \\
\hline $\begin{array}{l}\text { Industry future /State } \\
\text { policy }\end{array}$ & $\begin{array}{l}\text { Shift to deep mining to } \\
\text { secure future of enter- } \\
\text { prise }\end{array}$ & $\begin{array}{l}\text { World market price of } \\
\text { gold unstable }\end{array}$ & $\begin{array}{l}\text { Enterprise run down } \\
\text { Productivity decline }\end{array}$ \\
\hline
\end{tabular}

Source: Field notes, 2008

Locals less confident about the future of their enterprises were apprehensive of unstable world market for gold and manganese. The price instability they explained had the potential to undermine the security of employment especially for vocal local union leaders (Table 8.5a). They accused management of taking advantage of cost cutting or labour shedding exercises to get rid of vocal union leaders. Local union executives' assessment of union future was therefore tied to enterprise success. The two public mining enterprises covered had union executives doubtful of the future. One enterprise, a diamond mining company, had collapsed completely due to government failure to find a foreign investor to off-load ownership. At the time of data gathering, the mining enterprise was being cannibalised under a system of small contracts to what was termed 'tributaries', several small scale mining enterprises using very rudimentary methods for mining alluvial diamonds in the concessions of the company. This was taking place as large and more sophisticated machinery lay rotting away.

Workers insisted that the fate of the company was tied to political manipulations and personal interests of key political figures who were benefiting directly from the contract mining. Workers of the second mining company were very suspicious of management intentions and insisted that the mine had been sold and the transac- 
tions were being kept secret from workers to avoid severance payment. Here, workers were unsure of enterprise viability, blaming some managerial decisions which, for them, smacked of the self-seeking motives of Ghanaian politicians and public enterprise management personnel. The decision to continue using road haulage instead of rail for ore transport to the harbour for export long after the end of the rail strike that necessitated this arrangement was a case that was cited to back their accusations. GMWU local executives identified enterprise survival as the main threat to union future but concluded that credible efficient leadership was the key to shoring up union future.

Table 8.5b ICU Locals Assessment of Union Future

\begin{tabular}{|l|l|l|l|}
\hline Conditions & Bright future & Uncertain future & Bleak future \\
\hline $\begin{array}{l}\text { Union relevance/ } \\
\text { presence }\end{array}$ & $\begin{array}{l}\text { Locals offer workers } \\
\text { needed protection }\end{array}$ & $\begin{array}{l}\text { National union's response to } \\
\text { members needs } \\
\text { Effective worker solidarity }\end{array}$ & \\
\hline $\begin{array}{l}\text { Membership } \\
\text { expansion }\end{array}$ & $\begin{array}{l}\text { Young members highly } \\
\text { motivated by union }\end{array}$ & $\begin{array}{l}\text { Ability of locals to deal with } \\
\text { workplace concerns } \\
\text { Removal of regional officer }\end{array}$ & $\begin{array}{l}\text { Management style has } \\
\text { undermined union effec- } \\
\text { ity }\end{array}$ \\
\hline $\begin{array}{l}\text { Leadership capac- } \\
\text { style, capacity and } \\
\text { commitment }\end{array}$ & $\begin{array}{l}\text { Tax regimes and trade } \\
\text { liberalisation } \\
\text { Global economic down turn }\end{array}$ & $\begin{array}{l}\text { Privatisation } \\
\text { human resource devel- } \\
\text { opment } \\
\text { Industry fu- } \\
\text { ture/State policy } \\
\text { direction }\end{array}$ & $\begin{array}{l}\text { Absence of regulation } \\
\text { for foreign labour im- } \\
\text { portation }\end{array}$ \\
\hline
\end{tabular}

Source: Field notes, 2008

Optimism about ICU's future as a national union was based on the local executives' sense of union utility and the relevance for workers. The presence of young highly motivated union members was cited as reason for assigning their union a bright future. Here too, as for GMWU, the local union was seen as having a brighter future than the national union. There was generally a feeling of despondency about enterprise future which workers felt was being undermined by government policies. There was also the feeling that government attitude encouraged management hostility to workers. One local executive explained pointing at the interviewer:

Your government is killing Ghanaian industry in a nice manner. We are dying slowly, people are importing agro-processing equipment tax free but local enterprises producing agro-processing equipment have to pay VAT, income tax.... The future of manufacturing industries in this country is bleak the government has virtually sold the country to foreigners and does not allow its human resources to acquire skills because the importation of foreign labour is not regulated. National statistics are unreliable so government is not well informed about working conditions and the way foreign owners oper- 
ate in Ghana. Workers in Ghana are treated like slaves in their own country and foreign investors are allowed to maltreat Ghanaian workers. ${ }^{114}$

Others based their predictions of a bleak future for their enterprises on the general global economic crisis: 'the future of this company is shaky even the parent company and most subsidiaries have collapsed.'115

Union leadership quality and commitment were called into question. The ICU's leadership crisis remained unresolved at the time of data gathering and some locals were apprehensive about the interim leadership and its ability to secure membership interests over and above limited personal interests. In one region two out of the five locals of the ICU covered called for the removal of their regional officer for incompetence.

Table 8.5c GAWU Locals Assessment of Union Future

\begin{tabular}{|l|l|l|}
\hline Conditions & Bright future & Uncertain future \\
\hline Union relevance & $\begin{array}{l}\text { Empowering locals with resources } \\
\text { National union ability to keep locals united } \\
\text { Providing locals with social activities } \\
\text { Closing wage gap }\end{array}$ \\
\hline $\begin{array}{l}\text { Membership } \\
\text { expansion }\end{array}$ & Extending coverage to contract labour \\
\hline $\begin{array}{l}\text { Leadership com- } \\
\text { mitment }\end{array}$ & $\begin{array}{l}\text { Leadership personal interests do } \\
\text { not interfere with union } \\
\text { Good management local union } \\
\text { relations }\end{array}$ & $\begin{array}{l}\text { Renewal of leadership commitment and compe- } \\
\text { tency }\end{array}$ \\
\hline $\begin{array}{l}\text { Leadership capac- } \\
\text { ity }\end{array}$ & \multicolumn{2}{|l}{} \\
\hline
\end{tabular}

Source: Field notes, 2008

The expression of pessimism about the future of their unions by GAWU locals did not match that of ICU and GMWU locals. The local executives were uncertain of the future. Locals were watching to see what the change in national leadership, produced by the GAWU Quadrennial Delegates' Conference in January 2008, had in the offing for members. Some were certain that the new leadership would not allow personal interests to interfere with union values and goals. For others the good relations between local union leadership and management provided the key for union future. The less optimistic however, were uncertain about the ability of national leadership to give adequate power to the locals. This was in reaction to the practice in GAWU where CBA negotiations are conducted by national leadership, sometimes without backing from local union executives and the regional officers.

\footnotetext{
${ }^{114}$ Interview with local union executives, March 2008

${ }^{115}$ Interview with Neoplan local union executives, May 2008.
} 
Their absence in negotiations also meant that they lacked power to pursue local grievances and abuse of workers' rights and have to continuously rely on national leadership. It was the insistence on the part of national leaders to be part of collective bargaining negotiations that created some element of unease about the selfseeking intentions and to reinforce suspicions on the part of locals who were unhappy about the outcome of collective bargaining wage limits attained. Others felt the proportion of union subscriptions for regional officers was too little and resources in terms of office equipment, transportation facilities inadequate for officers to extend the support that the locals required. The rate of casual labour employment was identified as a threat to union future and some based union survival on their ability to extend coverage to causal and contract labour (Table 8.5c).

Local executives in the GPRTU stressed the relevance of their local unions to their immediate members as the foundation for union future. They were, like their counterparts in GAWU, less hopeful that the affiliation of their national union to the GTUC will support union survival. They felt that fuel deregulation and government control over the final limits of road transport fares undermined leadership commitment to the union and also placed the interests of the majority of formal sector based membership of the GTUC in conflict with the interests of GPRTU members (Table $8.5 \mathrm{~d}$ ). They were certain that neither the GTUC nor their national leaders spoke on behalf of the membership.

Table 8.5d GPRTU Locals Assessment of Union Future

\begin{tabular}{|c|c|c|c|}
\hline Conditions & Bright future & Uncertain future & Bleak future \\
\hline Union relevance & $\begin{array}{l}\text { Locals highly } \\
\text { beneficial to mem- } \\
\text { bers }\end{array}$ & & $\begin{array}{l}\text { National union and the GTUC } \\
\text { not relevant to members at } \\
\text { the local }\end{array}$ \\
\hline $\begin{array}{l}\text { Leadership com- } \\
\text { mitment }\end{array}$ & & & $\begin{array}{l}\text { Leaders listen to government } \\
\text { and not members } \\
\text { Self-seeking national leaders }\end{array}$ \\
\hline $\begin{array}{l}\text { Leadership capac- } \\
\text { ity }\end{array}$ & & & Low formal education \\
\hline Union pluralism & & $\begin{array}{l}\text { Union rivalry breaking down } \\
\text { discipline }\end{array}$ & \\
\hline $\begin{array}{l}\text { Industry future } \\
\text { State policy direc- } \\
\text { tion }\end{array}$ & & $\begin{array}{l}\text { Future of road transport } \\
\text { Condition of the roads } \\
\text { Centrally controlled fare } \\
\text { fixing }\end{array}$ & \\
\hline $\begin{array}{l}\text { Political interfer- } \\
\text { ence }\end{array}$ & & & $\begin{array}{l}\text { Political interference causing } \\
\text { fragmentation }\end{array}$ \\
\hline $\begin{array}{l}\text { Outcome of re- } \\
\text { search / Research }\end{array}$ & & $\begin{array}{l}\text { Research will get national } \\
\text { leaders to give better support } \\
\text { to members }\end{array}$ & \\
\hline
\end{tabular}


State support in terms of the provision of good roads was a determinant of the future of the GPRTU that local executives identified. Another development was the proliferation of splinter unions ostensibly to break the front of the union and its ability to resist government control over the fixing of transport fares that accompany frequent changes in fuel prices (Table $8.5 \mathrm{~d}$ ). Some demanded that 'the selfseeking national leaders should do a self-appraisal to find out the extent to which they have lived up to the expectation of members. The union is not living up to its relevance' was their conclusion. ${ }^{116}$ There was concern about the low formal educational background of union leaders. 'The national union' it was asserted, 'is the eye of the union, its leaders are the ones who speak on behalf of the locals and branches. Our national leaders should be scholars who can relate to high level professionals, government officials and politicians' ${ }^{\prime 17}$.

The focus of the GPRTU locals therefore, was more in terms of the sensitivity of the union to national economic policy, in particular, fuel deregulation that was threatening to undermine membership front through union fragmentation and leadership co-option. Their dissatisfaction with their leaders who were submitting to increasing government pressure to keep road transport fares low. This, they explained, was undermining the viability of their livelihoods, generating frustration and a general disconnection of leadership from its membership.

Like the GPRTU and GAWU, the local executives of the CBMWU's optimism for union future was based on their assessment of the fortunes of the workplace based unions. Workers' need for protection in the construction industry was high, they explained, and it is meeting this need that will secure the future for unionisation in the sector. Local executives were rather upbeat about union pluralism. For them allowing the operations of a multiplicity of unions will maintain unionisation among workers since locals can always opt out of ineffective national unions to join better performing ones (Table 8.5e). The locals of CBMWU showed high levels of disappointment with the performance of their national leaders and few had any confidence in the ability of the national leaders to sustain the union. This, coupled with the uncertainty they felt had bedevilled the construction industry, created high levels of frustration among locals, of private as well as in public enterprises. The general impression was that 'the union is weak' 'we do not feel the union', 'we do not see how the union is helping us' and 'the essence of forming a union is not being implemented'118. Local leaders felt that national leaders needed to understand that they cannot hold on to leadership for ever. Most of the interviews were conducted before the delegates' conference in June of 2008 and several interviewees expressed the hope that the union would be spared another quadrennial under the

\footnotetext{
${ }^{116}$ Interview with local union executives, May 2008.

${ }^{117}$ Interview with local union executives, March, 2008

118 Interview with local union executives, January to May, 2008.
} 
leadership of the incumbent General Secretary. Unfortunately this wish did not materialise and he still remains in office.

The extent of CBMWU local executives' loss of confidence in the effectiveness of their national unions was exposed in the chaotic explosion of anger by workers at one Chinese owned enterprise that was covered in the study. The workers refused to allow their leaders to be interviewed and over one hundred workers insisted on joining in the interview with their local leaders. They expressed anger and frustration at all forms of institutions and personnel: the police, their union leaders, ministers of state, officials of the labour office and labour commission. They cited several cases of abuse of workers' rights, low pay and unsafe work environment, the absence of protective clothing like boots and helmets. They presented as evidence injured bandaged touting colleagues who were forced to work with their work related injuries for fear of losing income.

Table 8.5e CBMWU Locals Assessment of Union Future

\begin{tabular}{|c|c|c|c|}
\hline Conditions & Bright future & Uncertain future & Bleak future \\
\hline Union relevance & $\begin{array}{l}\text { Workers need protection at } \\
\text { the workplace } \\
\text { May Day brings out union } \\
\text { relevance }\end{array}$ & & $\begin{array}{l}\text { National union not making } \\
\text { impact } \\
\text { Weak national union }\end{array}$ \\
\hline Membership Apathy & & & $\begin{array}{l}\text { No education for members } \\
\text { to understand their unions }\end{array}$ \\
\hline $\begin{array}{l}\text { Leadership com- } \\
\text { mitment }\end{array}$ & & & $\begin{array}{l}\text { No confidence in national } \\
\text { leadership }\end{array}$ \\
\hline Union pluralism & $\begin{array}{l}\text { Locals can join better } \\
\text { performing national unions }\end{array}$ & & \\
\hline $\begin{array}{l}\text { Industry future/ } \\
\text { State policy }\end{array}$ & & $\begin{array}{l}\text { Uncertain construction } \\
\text { industry future }\end{array}$ & \\
\hline
\end{tabular}

Source: Field notes, 2008

The leaders of the workers had first made complaints to the police, certain that their treatment at the hands of Chinese employers boarded on criminality. When they received no redress they contacted the Regional Minister and also received no support. They were led to the regional office of the GTUC where the Regional Secretary introduced them to the regional officer of the CBMWU. They were able to receive some redress and get some amount of protective clothing and secured wage increase. This gave confidence in the CBMWU and they initiated the process of union formation. But before the procedures for the local union could be formalised and a bargaining certificate secured there had been several cases of victimisation. This time the CBMWU failed to provide the needed protection for the victimised local leaders. The workers were certain the weakening of the national union executives was as a result of the corruption. They cite to support their case that the regional 
officer first meets with the Chinese management alone before he goes to talk to the interim executives whenever visits the construction site.

Overall there was within these workers an overwhelming anger at the weakness of institutions and organisations purporting to secure their protection as workers. Their anger was threatening to break out, under the burden of hopelessness, as disrespect for public officers, the police, ministers, union officials and even the then president of Ghana. They had similar disdain for public institutions and democratic processes. They kept asking why the state institutions had failed to offer them protection in their own country against the exploitation and abuse from foreigners and wondered why they should vote in the elections that were due in six months, December 2008. Theirs was one case of low confidence in the union structures. The national and regional officers insisted that it was more a case of misunderstanding and impatience with union processes than one of union failure. But the levels of dissatisfaction expressed by locals for their national union CBMWU, were generally low.

Public sector based locals of the CBMWU were equally critical of low levels of union relevance, and presence in the working lives of its members. Local executives of CBMWU in private enterprises exhibited feelings of insecurity during interview sessions, looking over their shoulders, speaking in undertones and some refusing outright to allow the interviews to be recorded on tape. They were also highly dissatisfied with national union leaders. Most felt let down by the national executives and were beginning to feel that they could not count on national leadership to come to their defence. Even though they found unionisation highly beneficial and wanted to remain members of unions, they explained that their national union, the CBMWU, was not effective in addressing their concerns. For locals, high turnover at work that most construction companies were facing was the result of worker dissatisfaction with working conditions. High turnover affects union membership; secure employment leads to a stronger union, they emphasised. They advised the national leadership to direct their efforts at securing the future of the CBMWU as an effective organ for promoting the rights of construction workers.

The MDU local executives covered in the study presented a similar case of low optimism like their counterparts in the CBMWU. None of the locals covered expressed any hope in union future and generally exhibited a low sense of union ownership. All the locals covered expressed low levels of confidence in the utility of the union and its response to membership concerns. This case was more accentuated for the casual workers of the Ghana Dock Labour Company (GDLC), an enterprise owned by the MDU and five other private concerns. The GDLC is made up of a casual pool of workers who service ships that dock at the two main harbours in Ghana and a small group of permanent staff who manage the casuals and are also members of the MDU. There was the need to make direct contact with the workers when interview sessions with local executive produced conflicting responses that were diffi- 
cult to verify. The union executives granted permission and offered the necessary introduction to workers. Sitting among workers of the company as they awaited their turn to collect their wages, immediate reactions on hearing the word union was 'We don't have a union'. They formed their own union' 'we don't own the union' 'the company is not listening' 'they did not come to help workers so the union is like a rubber stamp', 'the union is ineffective and once you make demands for better working conditions then you are accused of inciting workers' ${ }^{\prime 11}$. Interviews with the sister company in the second harbour city confirmed the general dissatisfaction of GDLC workers with their locals and national unions. They questioned the dual functions of MDU as an employer and workers' representatives in the same enterprise. Workers felt let down by their local union executives' inability to mediate harsh sanctions imposed by management on workers who break workplace rules.

Table 8.5f MDU Locals Assessment of Union Future

\begin{tabular}{|l|l|l|}
\hline Conditions & Uncertain future & Bleak future \\
\hline $\begin{array}{l}\text { Membership sense of union } \\
\text { ownership }\end{array}$ & $\begin{array}{l}\text { No sense of union ownership } \\
\text { Union as imposed by manage- } \\
\text { ment }\end{array}$ \\
\hline Membership Apathy & No respect for local union \\
\hline Leadership commitment & Leadership response to members & \\
\hline Leadership capacity & $\begin{array}{l}\text { Workers ability to chose own local } \\
\text { leaders }\end{array}$ & \\
\hline Industry future State policy & Ability of harbour to attract ships & \\
\hline
\end{tabular}

Source: Field notes, 2008

Management of the GDLC was made up of workers also organised under MDU. They were permanent staff. They insisted that the current working conditions for the casuals were better than before. The casual workers disagreed insisting that their risk allowance had been withdrawn and their present incomes lower than they received previously. Both management and the casual workers confirmed high turnover as a problem plaguing the company. According to the workers only employees too old to seek alternative employment were prepared to remain in the company and work under the prevailing conditions.

Interviews with the permanent staff union executives of the GDLC and local union leaders of the casuals revealed a disconnection between the two local unions. The casual workers at the lower end of the employment ladder confirmed the accusations of lack of connection and an absence of union ownership. Generally the union executives had a higher sense of privilege and of being in a superior position; their

\footnotetext{
${ }^{119}$ Interview with workers of Tema GDLC, February, 2008
} 
offices were better kept and furnished, air conditioned, while the casuals sat in sheds on concrete benches. The casuals expressed frustration over low wages, insecurity of employment and uncertain future, and revealed in their language a bottled-up anger in the face of their impotence to defend themselves. One exploded in broken English 'sanction dey here too moch', meaning there is too much sanctioning of workers here ${ }^{120}$. The permanent staff and union leaders justified arbitrary dismissals by stating that port workers by the nature of their work are unruly so they have to be 'controlled'. Their control, it was explained, took the form of suspension for 'misbehaving' which amounted to a loss of income. In a situation of low incomes and piece rate payments suspension from work meant near destitution.

Subsequent media reports confirmed the workers' decision to join a splinter union, the National Union of Harbour Employees. Its leader, a former Deputy General Secretary of the MDU who lost his position in circumstances he insisted were politically motivated, had been trying in vain to secure a bargaining certificate. His efforts were being thwarted by MDU leadership. As at the time of writing, the verification exercise to determine which union had the majority membership among the workers had failed to come on as scheduled by the Chief Labour Officer. In May, 2009 workers of the GDLC in Tema held an industrial action to protest the delay. Their struggle still continues and the resolution of their membership has significant repercussions for the MDU since they form the majority of its membership.121

The locals confirmed their belief in unionisation. Local union executives gave a prominent role to their national unions and leadership for shaping the environment that would support union survival. Their concern was more with the exercise of leadership power and priorities and less with the inadequacy of union structures and processes. By their estimation the priorities of the national leadership tended to conflict with union goals thus undermining union utility, relevance and finally its influence and authority. External threats to enterprise viability identified included state policies, political interests and management practices.

Box 8.1 summarises the challenges presented by the locals showing the location or struggle sites where local engaged their challenges. The struggle sites were both external and internal to the local unions. Externally located struggles targeted government policies, institutions and the legal framework. Politicians, Ghanaian management and foreign employers' disdain for unions also shaped the content of union struggles. Internal challenges emanated from the national and local unions (see Box 8.1). External challenges impacted the size of unions because they affected the existence of enterprises and determined how many workers were employed. Inter-

120 Interview with workers' of GDLC, February, 2008.

121 See the Ghana News Agency report filed on Friday, May 29, 2009 titled 'Two labour Unions Strike over membership'. On http://www.modernghana.com/news/219222/ 
nal factors affected membership quality and morale thus impacting institutional capacity of unions for renewal (Behrens, Hamann, \& Hurd, 2004a). External factors generate the need for union existence while internal factors constrained union ability to deliver effectively to its members.

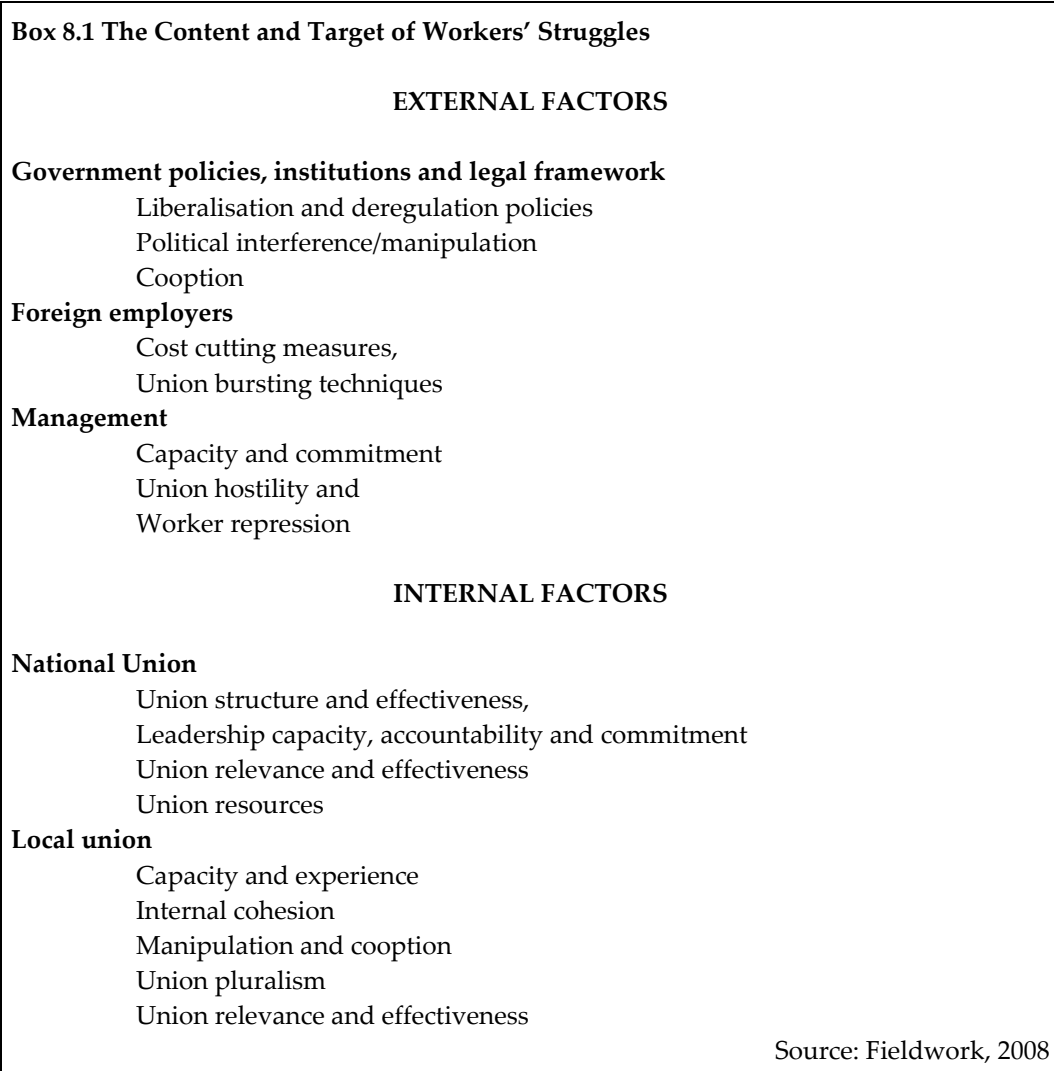

\subsection{STRATEGIES FOR ENGAGING WORKPLACE STRUGGLES}

As explained earlier, members experience their unions in the workplace. The test of union relevance therefore can be found in its performance in the workplace. Union relevance will as a result be found in the factors that either bind members to their unions and those that estrange members. While alienating factors can exercise a moderating influence on unions to the extent of rendering their strategies ineffective, factors that bind locals to their unions in an egalitarian way, provide an empowering impact. This section examines how locals mitigate threatening workplace challenges. It identifies the nature of the support system available for locals and how they translate into power tools for engaging workplace struggles. The support 
systems are examined in terms of those related to membership entitlements, as well as union processes and structural capacity.

Locals addressed their workplace challenges in several ways using an array of channels and relationships which produced varying levels of outcomes for members (Tables 8.6a, b, c, and d). Union pluralism helped to strengthen membership entitlement of the locals. Locals could renounce their affiliation. Disaffiliating from a public sector based national union to join the GMWU proved a blessing for one of the locals covered in the study. This took the form of a salary hike. The presence of multiple unions in the workplace also put pressure on national unions to continuously remain in touch with the local and serve their needs (Table 8.6a). Having plural unions in one enterprise also enhanced the response of national unions to three locals affiliated to GAWU, GMWU and the other MDU. The fear of losing members forces national unions to be more responsive to their members needs. Local executives covered in the study observed that their national unions' response to members needs has improved remarkably as a result (Table 8.6a). Union pluralism was a form of membership entitlement that offered local unions security against neglect from their national unions.

Membership servicing was a means for meeting workplace challenges and focused on supplementing workers' salaries, providing social security and leisure. Through such services the local and national unions, aimed to foster a sense of unity and solidarity among union members and increase their relevance. Income supplementation ventures involved the provision of credit and hire purchase schemes for locals. Life and health insurance schemes, in addition to old age support, were some of the schemes unions employed to provide social security for their members (Table 8.6a). Locals used leisure and recreational activities to foster a sense of union solidarity among members. Welfare schemes were also used by the locals to enhance union image and retain members.

Social security, unemployment and old age support schemes were important servicing schemes that unions like the GPRTU used to retain members in the face of fierce competition from rival unions (Table 8.6a). Such strategies helped secure members solidarity by increasing their sense of union ownership. A strong sense of ownership was important for mobilising members to support union demands. Membership servicing however stands the danger of becoming an end in itself and less of a means to an end. Unions easily turn to assume responsibility for securing avenues for improving the working conditions and benefits that workers should derive from their employers or the state. By securing access to credit to supplement workers' income for example, unions relieve employers of the responsibility for sharing equitably, the value derived from workers' input into the production of goods and services. Social security provision also relieves employers and the state of their fundamental responsibility. The challenge here is how unions use such activities merely as a membership mobilisation strategy. 
Table 8.6a Engaging Workplace Struggles: Membership Entitlements

\begin{tabular}{|c|c|c|c|}
\hline $\begin{array}{l}\text { Engagement } \\
\text { Strategies }\end{array}$ & Methods Employed & Outcome & Unions \\
\hline Union exist & - Changed union affiliation & $\begin{array}{l}\text { - Better benefits than rival } \\
\text { union } \\
\text { - Improved working } \\
\text { conditions }\end{array}$ & $\begin{array}{l}\text { GAWU, } \\
\text { GMWU, } \\
\text { MDU }\end{array}$ \\
\hline Union pluralism & $\begin{array}{l}\text { - } \text { Courting members of rival union } \\
\text { - } \text { Referendum to determine national } \\
\text { union popularity }\end{array}$ & 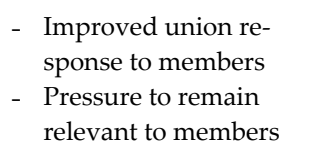 & $\begin{array}{l}\text { GAWU, } \\
\text { GMWU, } \\
\text { MDU }\end{array}$ \\
\hline $\begin{array}{l}\text { Membership } \\
\text { benefits (Servic- } \\
\text { ing) }\end{array}$ & $\begin{array}{l}\text { - Educational endowment fund } \\
\text { - Consumer shop/Credit and hire } \\
\text { purchase schemes } \\
\text { - } \text { Loan schemes/ access bank to loans } \\
\text { - Yearly bonus/end of year package } \\
\text { - Scholarship schemes for dependants, } \\
\text { - } \text { Recreation centre/ keep fit club } \\
\text { - Welfare and funeral benefits } \\
\text { - Social security/unemployment/old } \\
\text { age support /Health insurance } \\
\text { - Union income generating schemes } \\
\text { Vehicle/offices/hostel for renting }\end{array}$ & $\begin{array}{l}\text { - Members sense of union } \\
\text { relevance Improved } \\
\text { - Enhanced union fi- } \\
\text { nances }\end{array}$ & $\begin{array}{l}\text { CBMWU, } \\
\text { GMWU, } \\
\text { GPRTU, } \\
\text { ICU, MDU }\end{array}$ \\
\hline
\end{tabular}

Source: Field data, 2008

Membership entitlements provided the avenue for locals to ensure better response from their national unions. The capacity of the locals also served to expand their space in their national unions. The strategies deployed that relied on the structural capacity of unions were internal cohesion, solidarity, membership education and competency. Other support systems included assistance from regional and national unions to deal with the daily workplace challenges (Table 8.6b). Locals used union activities like May Day parades, scheduled union meetings and workers' performance monitoring as a basis for building internal union cohesion and solidarity. Local executives explained that this enabled them to improve understanding and unity among members, and increase their interest in union activities. In some instances locals of GPRTU attempted to force attendance at union meetings through the institution of sanctions. Membership quality helped to enhance the status of the locals in the workplace and the national unions. Senior staff unionisation was a strategy that helped to enhance the membership of the locals especially in the case of GMWU, GAWU and ICU.

Union members felt empowered by their ability to remove from office leaders who they felt were not responsive to members. A challenge identified by locals was leadership disunity produced by employer cooption and hostility. This, some had chosen to counter, by team-building skills. Deepened unity and cooperation between local executives and their members caused management to be cautious in its dealings with locals (Table 8.6b). Union education, a strategy adopted by locals to en- 
hance membership capacity was executed through mass quarterly meetings, regular union meetings and seminars. Quarterly newsletters and CBAs were the documents that locals used to provide their members information (Table 8.6b). Inter union support to back local power was secured through their representation on national and regional union decision-making structures like the QDC, NEC, RCLs and regional and branch unions.

Table 8.6b Engaging Workplace Struggles: Structural Capacity of Unions

\begin{tabular}{|c|c|c|c|}
\hline $\begin{array}{l}\text { Engagement } \\
\text { Strategies }\end{array}$ & Methods Employed & Outcome & Unions \\
\hline $\begin{array}{l}\text { Local union } \\
\text { competence }\end{array}$ & $\begin{array}{l}\text { - Senior staff unionisation } \\
\text { - } \text { Removed union leaders } \\
\text { form office } \\
\text { - Standardising work of } \\
\text { branch secretary } \\
\text { - } \quad \text { Team building }\end{array}$ & $\begin{array}{l}\text { - Greater union leadership unity } \\
\text { - New union building structures } \\
\text { - Enhanced union status }\end{array}$ & $\begin{array}{l}\text { GAWU, } \\
\text { GMWU, } \\
\text { GPRTU, ICU }\end{array}$ \\
\hline $\begin{array}{l}\text { Union cohe- } \\
\text { sion and } \\
\text { solidarity }\end{array}$ & $\begin{array}{l}\text { - May Day celebra- } \\
\text { tions/parades } \\
\text { - } \text { Regular meetings } \\
\text { - } \text { Penalty for not attending } \\
\text { meetings } \\
\text { - } \text { Monitoring members' } \\
\text { work behaviour }\end{array}$ & $\begin{array}{l}\text { - Improved understanding and } \\
\text { unity among members } \\
\text { - More organised and increased } \\
\text { interest in union activities } \\
\text { - } \text { More cooperation with workers } \\
\text { - } \text { Better relations between senior } \\
\text { and junior staff } \\
\text { - } \text { Management careful with union } \\
\text { because of membership support }\end{array}$ & $\begin{array}{l}\text { CBMWU, } \\
\text { GAWU, } \\
\text { GMWU, } \\
\text { GPRTU, ICU }\end{array}$ \\
\hline $\begin{array}{l}\text { Union educa- } \\
\text { tion }\end{array}$ & $\begin{array}{l}\text { - } \text { Mass quarterly meetings } \\
\text { - Discuss grievances at } \\
\text { meetings and durbars } \\
\text { - } \text { Distribute quarterly news- } \\
\text { letters and copies of CBA } \\
\text { - Educate members on: } \\
\circ \text { Discipline and produc- } \\
\text { tivity } \\
\circ \text { Contents of CBA } \\
\circ \text { Trade unionism } \\
\circ \text { Health and safety } \\
\circ \text { Road traffic regulations }\end{array}$ & $\begin{array}{l}\text { - Union serious about information } \\
\text { dissemination } \\
\text { - Workers well informed } \\
\text { - Improved productivity } \\
\text { - } \text { Temper workers' demands in } \\
\text { respect to company's distress }\end{array}$ & $\begin{array}{l}\text { CBMWU, } \\
\text { GAWU, } \\
\text { GMWU, } \\
\text { GPRTU, ICU }\end{array}$ \\
\hline $\begin{array}{l}\text { Inter union } \\
\text { Support }\end{array}$ & 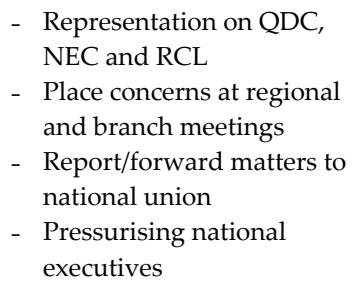 & $\begin{array}{l}\text { - Union structures now well de- } \\
\text { fined Improved relations with na- } \\
\text { tional union } \\
\text { - } \text { Regional officer quick to respond } \\
\text { to CBA violations } \\
\text { - Uniform placement for all bank } \\
\text { workers in the region } \\
\text { - Frequent visits from national chair }\end{array}$ & $\begin{array}{l}\text { CBMWU, } \\
\text { GAWU, } \\
\text { GMWU, } \\
\text { GPRTU, ICU }\end{array}$ \\
\hline
\end{tabular}


Locals also used the reporting mechanisms of their national unions to place their concerns before the national unions and to pressurise national executives. Local union executives explain that such measures had led to improved relations with their national unions. GAWU, GMWU and ICU locals reported that they are able to garner quick responses to CBA violations and receive regular visits from national and regional union officers (Table 8.6b). Representation on national union bodies and influence over national and regional officers were avenues used by locals to influence their national unions and secondly improve their clout at the workplace. CBMWU, GAWU, GMWU GPRTU and ICU locals reported access to inter union support for addressing workplace challenges. MDU locals however did not mention such facilities (Table 8.6b).

Union processes offered the locals a whole arsenal for meeting workplace challenges (Table 8.6c). The CBA formed the standard workers used to defend their rights and when this failed they backed their demands with protests. As one local executive explained, 'the CBA is our constitution here in the workplace. When it speaks no one can challenge $i^{\prime}{ }^{122}$

Some locals of GMWU reported undertaking research to enhance their bargaining power during negotiations. Local union executives reported regular negotiations others were involved in the extension of CBA coverage to all workers or expanding the tenets of benefits offered under their CBAs. Some locals had been able to extend CBA coverage to all workers irrespective of their employment status and secured enhanced working conditions, like regular working hours, recognition for overtime payments, transparent promotion schedule and the removal of salary disparities (Table 8.6c). Where avenues for negotiations were closed, local executives reported using demands and protests to access their needs. Protests were used against union officers and management (Table 8.6c).

National union officers were used to pressurise management. The outcome of workplace demands has been getting salaries paid through the bank (CBMWU), stopping management from selecting local leaders and sitting in union meetings (GAWU) as well as ending arbitrary dismissals (GMWU and ICU). MDU local executives reported that workers' protests were instrumental in getting management to construct a waiting shed for casuals at the harbour. This brought to an end standing under trees while waiting to be assigned to service docked vessels at the harbour.

${ }^{122}$ Interview with local union executives March, 2008. 
Table 8.6c Strategies for Engaging Workplace Struggles: Union Processes

\begin{tabular}{|c|c|c|c|}
\hline $\begin{array}{l}\text { Engagement } \\
\text { Strategies }\end{array}$ & Methods Employed & Outcome & Unions \\
\hline Negotiations & $\begin{array}{l}\text { - Use CBA as standard to } \\
\text { defend workers } \\
\text { - Worked to extend/altering } \\
\text { CBA benefits } \\
\text { - } \text { Regular/yearly negotiations } \\
\text { - } \\
\text { Research to support negotia- } \\
\text { tions }\end{array}$ & 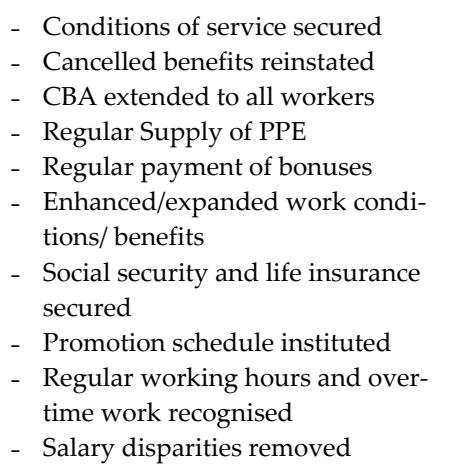 & $\begin{array}{l}\text { CBMWU, } \\
\text { GAWU, } \\
\text { GMWU, ICU, } \\
\text { MDU }\end{array}$ \\
\hline $\begin{array}{l}\text { Demands and } \\
\text { Protests }\end{array}$ & 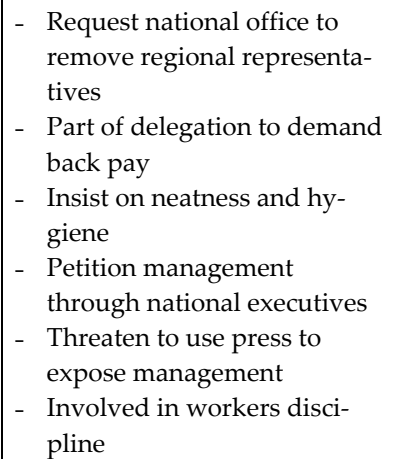 & $\begin{array}{l}\text { - } \text { Salaries passed through banks } \\
\text { - } \text { Instituted overtime payments for } \\
\text { extra working hours } \\
\text { - } \text { Stopped management from select- } \\
\text { ing union leaders and sitting in un- } \\
\text { ion meetings } \\
\text { - } \text { Broke culture of silence } \\
\text { - }\end{array}$ & $\begin{array}{l}\text { CBMWU, } \\
\text { GAWU, } \\
\text { GMWU, ICU, } \\
\text { MDU }\end{array}$ \\
\hline
\end{tabular}

Source: Fieldwork, 2008

Local union executives used their relations with persons and organisations beyond their unions to support their workplace demands (Table 8.6d). Management, the immediate workplace partners, served as avenues that were utilised to press home demands. As one group of local union executives of ICU explained, the executives have been

'trained to understand that the union is not there to bully management to but solve problems. The relations with management is like those between children and their parents, sometimes they are good, sometimes bad. We don't always expose them but try to work together.' ${ }^{123}$

Such cooperation involved lobbying management, using workers representatives on management boards and holding special meetings with management (Table 8.6d). By cooperation, according to union executives, management has a better appreciation of unions, thus enhancing worker/management relations. Some locals explained that the tension that used to exist between workers and their management in the workplace has reduced substantially. These local executives cited in support

${ }^{123}$ Interview with local union leaders, March, 2008 
of this assertion the reduced industrial action by workers, correct application of sanctions and an end to arbitrary dismissals (Table 8.6d). An interesting outcome of such collaboration is the case of ICU workers who used their gratuity to bail out their distressed public sector company to save it from collapse.

Table 8.6d Engaging Workplace Struggles: Management and External Agents

\begin{tabular}{|c|c|c|c|}
\hline $\begin{array}{l}\text { Engagement } \\
\text { Strategies }\end{array}$ & Methods Employed & Outcome & Unions \\
\hline Management & $\begin{array}{l}\text { - Meetings with management } \\
\text { - } \text { Representation on management } \\
\text { board } \\
\text { - } \text { Address problems at manage- } \\
\text { ment meetings } \\
\text { - } \text { Lobby management }\end{array}$ & $\begin{array}{l}\text { - Improved relations with man- } \\
\text { agement } \\
\text { - } \text { Management understanding of } \\
\text { unions has } \\
\text { - } \quad \text { Reduced workplace tensions } \\
\text { - } \text { Management accepts and listens } \\
\text { to union } \\
\text { - } \quad \text { Ensure correct application of } \\
\text { sanctions }\end{array}$ & $\begin{array}{l}\text { CBMWU, } \\
\text { GAWU, } \\
\text { GMWU } \\
\text { ICU }\end{array}$ \\
\hline $\begin{array}{l}\text { External } \\
\text { agents/ organi- } \\
\text { sations }\end{array}$ & $\begin{array}{l}\text { - District Chief Executive, District } \\
\text { Assebly/management Committee } \\
\text { - } \text { Ministry/Regional Minister } \\
\text { - } \text { Board chair } \\
\text { - } \text { Religious bodies } \\
\text { - Press conferences } \\
\text { - Parliamentary select committee } \\
\text { - } \text { Chiefs } \\
\text { - } \text { Internet alliances and networks }\end{array}$ & $\begin{array}{l}\text { - Resolve worker disputes } \\
\text { - } \text { Petition against abuse }\end{array}$ & $\begin{array}{l}\text { CBMWU, } \\
\text { GAWU, } \\
\text { GMWU, } \\
\text { ICU }\end{array}$ \\
\hline
\end{tabular}

Source: Field data, 2008.

Politicians, public officers, chiefs and the press were external agents that local executives reported using to push their demands in the workplace. When asked why they resorted to the District Chief Executive, their sector or Regional Minister for arbitration of workplace disputes one group explained that 'politicians are like our father and if workers have a problem they should know that their children are suffering' ${ }^{\prime 24}$ A regional officer of ICU preferred to use the Regional Minister instead of the national union channels to resolve salary negotiations stalemate. The added explanation was that since it was an election year workers had to be careful not to allow their industrial struggles to be read as being 'politically motivated'. The most effective of the external agents in empowering local unions however, was the press which local unions used to shame management or attract public sympathy for their cause. The use of politicians and key religious figures gave little support for workers' cause and usually the arbitration efforts sought to tamper workers' demands. The outcome of such strategies for the resolution of workplace disputes and abuse have therefore been limited (Table $8.6 \mathrm{~d}$ ).

\footnotetext{
${ }^{124}$ Interviews with local union leaders, May, 2008
} 


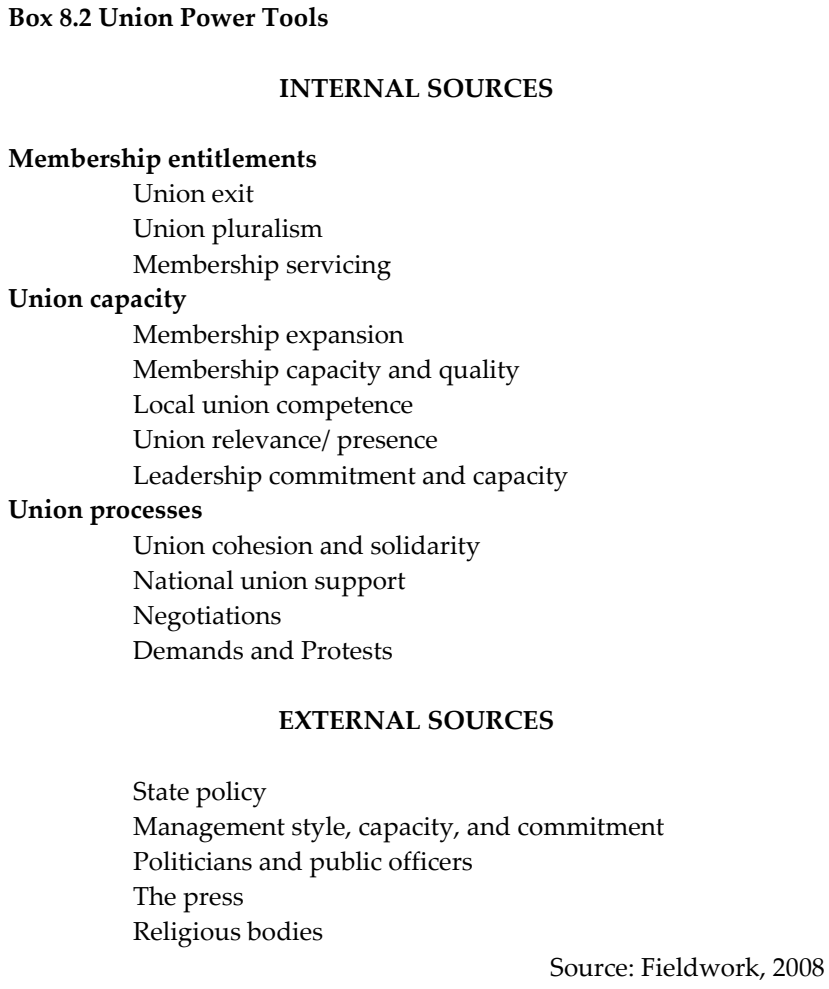

Like the struggle sites, sources of union power tools were located within and outside the unions. Union membership entitlements, processes and structures were key sources of power tools (Box 8.2). Power tools however were interrelated with external sources impacting internal and internal sources also expanding the effectiveness of others. Membership entitlements for example helped to promote union processes like membership cohesion and solidarity. Leadership commitment and capacity also enhanced union relevance and presence which in the final analysis improved solidarity and cohesion. Power tools backed union authority and influence and helped to position unions as a formidable force worthy of management attention and by extension helped unions to impact state policies.

\subsection{SUMMARY AND CONCLUSION}

This chapter examined how the interplay between union functions, role and activities provided sufficient room for a meaningful engagement of local unions with their national union for the pursuit of their interests. Utilising the notion of union power tools framework from the previous chapter, this chapter sought to identify available union power tools in the functioning of union structures and processes at the workplace. The local unions covered were of different ages and located in different industrial sectors. Enterprise ownership structure spanned both the public 
and private including the self-employed. Union membership was mainly male and junior staff of formal employment. Female membership was generally low especially in the private sector, with GPRTU, MDU and GMWU presenting the least number of women workers. Senior staff membership was beginning to expand in the financial and mining sector. Informal economy workers, though in the minority, were found mainly in the transport sector. Union size was determined by the nature of economic challenges confronting their sectors. Casualisation, labour intensive technology and employment freeze were constraining the expansion of union membership.

Unions emerged from several initiatives, with private sector based locals more likely to be formed in response to employment dissatisfaction and those in the public sector, as a requirement of the IRA 299. National union coverage was conceived as important for bolstering union authority and influence in the workplace. The interaction between locals and their national unions were limited to branch, district and regional meetings. National union affiliation was meeting workers' expectations in varying degrees.

The constitutional provisions of the national unions placed the locals at the lowest level within the union hierarchy, offering them autonomy to determine workplace concerns like daily operations for recruiting and maintaining members, election of officers and employment of union staff where applicable. The locals though had little by way of constitutional access for engaging other union structures. The supervisory role of regional and national bodies and officers over the activities and funds of the locals constrained independence and limited the ability of local unions to critically engage their national unions. This restrained members from demanding inclusion in union decision-making and created some level of dependence on Regional officers to access national union policy making bodies or officers. Constitutional guide lines for controlling locals constrained their operational space and hampered access to power tools, especially union based power tools like participation and inclusive avenues, representation and accountability systems for calling union leaders to order. Union structures as outlined in the various national union constitutions therefore do not serve as effective sources of power tools for the local unions. The positioning of the local unions within the national unions is consistent with the way in which the GTUC treated its regional and district structures.

The workplace roles of locals were defined by working conditions and survival demands of workers and the industrial challenges of their enterprises. The CBA served as the framework within which most formal economy based locals pursued their workplace functions. The functions of the locals extended beyond the direct benefits from their production efforts at work to the survival of their enterprises. The locals used educational activities to develop membership quality. The GPRTU locals served their interests through welfare provisioning and policing conduct of 
members while at work. Unlike the other national unions the GPRTU was able to extend entitlements beyond the working life of members.

The content of local union struggles was their workplace challenges and factors that threaten union survival. The sources of these threats and challenges constituted the struggle sites and targets of their struggles. Factors boosting union existence enhanced union positions and served as power tools for engaging union struggles. The sites and targets of union struggles as revealed through union challenges were government policies and management practices that weakened enterprise survival and therefore union existence. Within the unions members struggled to make their unions responsive to their needs. The union relevance especially at the workplace, union size and quality as well as leadership commitment were important power tools that served to shore up unions in the workplace. Union leadership priorities limited union influence and rendered unions less relevant for workers. Union leadership priorities, especially at the national level were factors that stopped unions from meeting their commitments towards their members. Internal factors that disempowered the locals have to be confronted if unions are to live up to their functions. External factors threatened unions only to the extent that union leadership was consumed by issues other than the interests of their members, usually parochial interests, thus rendering the locals less relevant for members.

The most effective power tool was the general belief that unions were the most important form for meeting workplace challenges. Overall, however, most local union executives were certain that the future of their unions depended on how workers problems are solved. The conception of membership and the corresponding entitlements however constrained access to power tools. As explained, membership entitlements were limited to how members can secure direct benefits from their national unions and less in terms of how they can expand their voices in their unions and impact union decision-making on a continuous basis. Union effectiveness derives from a continuous engagement of members in union decision-making and ability to use union process and structures to impact not only union direction but state policies and management attitude to employment conditions and enterprise survival. 


\section{Chapter 9}

CONCLUSION 


\section{CONCLUSION}

\subsection{INTRODUCTION}

Globalisation challenged labour and its representative organ, trade unions, through a fundamental reformulation of production forms and the re-structuring of labour markets, impacting the working space and production relations. The trend appears to be a displacement of working people from formal work sites on which earlier notions of trade unions were developed to more precarious jobs that make union organisation difficult. The erosion of the limited benefits secured earlier by workers through struggles with capital and the accompanying weakening of the labour movement at the forefront of workers' struggles constrain union ability to attract, retain and effectively represent members (Wood, 2004, p. 12). The initial disorganisation wrought by the impact of globalisation has been countered by serious attempts on the part of trade unions to face up to the challenge through a mix of actions. These actions were generated in the context of rethinking trade union function in order to evolve appropriate structures for dealing with the varieties of work and gendered social relations that permeate the work space and unions.

Trade union renewal or revitalisation involves strategies on the part of unions to reverse membership decline and secure their presence and legitimacy as effective workers' organs. The goal of trade union renewal therefore, is to strengthen unions by making them more appealing and relevant to the workers they represent. It is generally acknowledged that successful outcomes of union renewal or recomposition to meet the challenges of globalisation depend on the effectiveness of the strategy process and content or repertoires (Lambert, 2002; Fairbrother, 1990; Munck, 2002). Union repertoires are externally and internally determined. External factors located within the production forms and their corresponding relations, state attitude to unions, the subsequent political roles union assume and who they choose as strategic partners. The political roles of unions according to Harrod \& O'Brien (2002), have varying importance in different countries and are subjected to state control for this reason (Harrod \& O'Brien, 2002). External factors attempt to continuously shape union goals away from the interests of its members. Internal factors boil down to union size, and density of membership as well as union strategic location. Additionally the internal cohesion and solidarity among members affect the scope and content of union functions as well as its ability to embrace a range of issues beyond the workplace (Harrod \& O'Brien, 2002). The internal factors that 
determine successful revitalisation outcomes point to the importance of union internal democracy in charting the eventual chances of union survival.

Union democracy is presented variously as a struggle over union agenda between members and leaders on one hand, or representation of the varied interests of a heterogeneous membership on the other (Heery \& Fosh, 1990). The relations between union members and their leaders have been subjected to several interpretations and explanations either deterministically within union's inherent oligarchic nature, the need for leaders to ensure disciplined membership to adhere to the tenets of corporatist compromises, or as a tendency on the part of leaders to distort workers' goals or an outright betrayal of working class struggles (Streeck \& Hassel, 2003; Heery \& Fosh, 1990; Undy \& Martin, 1984). For others however deriving a truly representative collective interest within a diverse membership lies at the heart of trade union internal democracy (Curtin, 1999). Union internal power dynamism has been captioned as intra union power game or interest mediation (Poole, 1981), goal divergence or convergence (Curtin, 1999). Other renderings include the reconciliation of differences (Hyman R. , 1999) or the institution of hegemonies through a system of exclusion and resistance (Ledwith, 2009). Discussions on union democracy point to the complexity of unions as representative organs under the influence of a wide range of competing interests shaped by their internal dynamics and external environment.

Divergent explanations lead to varying solutions for union democracy. While some of the conservative traditions insist on promoting the rights of individual members over the collective, feminist and corporatists maintain the need to promote sectional interests in a situation that balances separate and collective organisation (Undy \& Martin, 1984). There is some scepticism about the ability of unions to achieve a common unity of purpose without broadening their concerns beyond the workplace. Curtin (1999) and Fairbrother, (1990) believe that the answer to deriving a truly representative union interest lies in an ideology that compels unions to extend their agenda beyond the workplace to cover social, political and economic issues at the national and global level. Ledwith however, suggests the formation of a counter-hegemony (2009). The importance of a coherent union ideology for sustaining effective renewal strategies have also been underscored by Lambert (2002), Streeck and Hassel (2003), as well as RoyChowdhury (2003). These observations are based on the notion that union ideology drives union political agenda and determines the political space that unions occupy. Limiting union democracy to a struggle between leaders and members or around the divergence or convergence of union goals assume some level of agreement among members over union direction devoid of external interests. The internal dynamics of trade unions are dependent on the composition and hierarchy of relations that evolve in terms of workers' background, like gender, class, race, ethnicity, and their economic location (Hensman, 2002; Koch-Baumgarten, 2002). Such factors, though external to unions, generate additional forms of contestations within unions and circumscribe spaces 
for union members. Heery and Fosh's suggestions about the need to place intra union struggle within a time and spatial context highlights the equal importance of external as well as internal factors in union democracy (Heery \& Fosh, 1990). Such discussions, important as they are in explaining the implications of intra union power dynamism for internal democracy, offer little explanation of how union revitalisation impacts union democracy to shape renewal outcomes. This calls for more clarity about how renewal strategies, irrespective of their outcomes, impact union internal democracy in order to broaden concerns about union revival beyond membership decline. A better understanding of the effectiveness of renewal strategies for union survival therefore has to be anchored in understanding the nature of modifications in membership positioning and interaction as unions revitalise.

Union revitalisation studies interrogate the proactive efforts by trade unions to influence contemporary developments that affect their 'relevance and effectiveness' (Kelly \& Frege, 2004). Different studies have either tried to account for the diverse mix of union choices or the variations in outcomes. Kelly and Frege offer a useful categorisation for the examination of the content of union revitalisation strategies. Behrens et al also show through their dimension of union revitalisation framework how union strategies interact to influence union power in the four spheres of union activities of membership, economic, political and institutional vitality (Behrens, Hamann, \& Hurd, 2004a). Their framework is influenced by Hyman's three identities of trade unions which they use to emphasise the interconnectedness of the dimensions of revitalisation in the four areas of union action. Behrens et al pose institutional dimension as fundamental to successful revitalisation. For them union institutional revitalisation is determined by the organisational structures, governance and internal dynamism. Institutional revitalisation however is conceived as a purely organisational affair dependent on leaders who shape union identity and goals to focus on the remaining social, political and market spheres of union activity (Frege \& Kelly, 2004). The dimensions of revitalisation connect union renewal and internal democracy quite forcefully but its reliance on organisational and social movement theories leads it to overlook the place of unions within the broader struggle of workers under capitalism. Different ways of conceptualising union internal democracy point to the fact that union internal democracy is about a struggle around class interests and the ability of members to utilise their unions in the pursuit of their interests as working people. Crisp's labour control and resistant framework for example connects union internal democracy with class struggles (Crisp, 1984). Andrae and Beckman's labour regimes framework situate union internal democracy within broader structures of social economic and political power (Andræ \& Beckman, 1998). These two show how attempts to control unions target specific structures of union solidarity, mobilisation and autonomy. They also point to the location of union action sites and membership rights as constituting important avenues for union members to use their union to engage the various forms of struggle. These considerations were used to develop tools for investigating the issue of internal democracy brought to the fore by the three identifiable groups of union members 
differentiated by their gender, economic location and class origins within union structures.

\subsection{EXPLORING UNION RENEWAL AND INTERNAL DEMOCRACY}

The exploration of the implications of union renewal strategies for internal democracy, as explained earlier, was centred on three distinct membership spaces within the GTUC and its national unions. They were the informal economy union membership, female structures as well as the regional, district and the enterprise based union organs. The decision to investigate these spaces was informed by three union renewal strategies of the GTUC and its national affiliates that were targeting membership expansion in the informal economy, gender democracy and the revamping of union consultative structures to consolidate the participation and representation of existing union membership. These three locations represented membership differentiation in terms of gender, class and economic location. As explained earlier, trade unions have different relations with their members based on their unique location within the unions. These three factors were identified as bearing on union membership and giving differences in terms of union membership with implications for union representativeness, effectiveness and relevance. The GTUC and the national unions, aware of how such backgrounds differentiate their members have set out specific strategies to address the nature of their engagement from the space they occupy within their unions. After all, unions are about their members from whom they derive their existence, legitimacy and influence. Their legitimacy, influence and corresponding status that emerge are obtained from the various locations of their members and the perceived interactions among them. The three locations of union members, informal economy, gender democracy and mainstream consultative structures yield peculiar challenges to the overall internal democratic ordering of organised labour. Taken on their own they provide just one side of a multifaceted amalgam of union membership identity that mediates internal democracy and draws attention to the various sites of union internal dynamism during revitalisation.

The focus of the study and the need to examine events in formation without the ability to control them rendered the case study an appealing approach to adopt. The case study approach also allowed both similarities and peculiarities to be highlighted. The case study comes with its own modes of data gathering relying on interviews, observations and document reviews. The methods used in this study were individual, group as well as key person interviews of union executives at the national, regional, district and in the three organs of union representation outlined. Other methods employed were observations at union meetings, conferences, and workshops. Union documents like constitutions and bye-laws, reports, policy instruments and minutes were used to provide background information and check reliability of interviews. 
Methodological and information sources triangulation, were used to control the reliability of research information. Interpretation bias was checked through feedback with research participants and union officers. Rival and splinter unions also served as points for validating the reliability of information gathered. The need to protect the confidentiality of research participants, especially in situations that could compromise their jobs, called for subsuming information sources in ways that made peculiar cases difficult to be isolated. Distilling meaning out of the information gathered was incorporated into the research proceeding from the field through editing and coding. The three levels of open, axial and selective coding were used to generate descriptive, explanatory and analytical codes. The themes for organising codes were developed from factors identified as conditioning trade union experiences at the national and the confederation level. In the specific case of making meaning out of information from the membership organs, the themes that guided the categories distilled were, the members sense of union ownership, the nature of their workplace and union struggles and how union membership processes and structures formed the basis for the engagement of these struggles. The themes also sought to distil information on alternative sources of power for engaging work related struggles by union members in the three locations.

The peculiar challenges identified by the GTUC and its affiliate national unions guided the choice of strategies selected for this study. These challenges were the expansion of the role of private foreign capital in Ghanaian production relations that was causing membership loss, and the process of informalisation pushing workers out of the traditional remit of unions. The institutional power of GTUC had shrunk with the reform of the Ghanaian Labour Act which legalised union pluralism. Salary reforms were eroding its bargaining function for public sector workers. The workplace presented additional challenges for the national unions as a result of the increasing sophistication in managerial practices and employer hostility. Such workplace, legislative and policy originated challenges tasked the capacity of union human and physical resource to defend their members. The capacity of union staff and elected officers to deal with managerial sophistication and understand the political economy of globalised capital and how it impacts national policy were constantly under test. The GTUC and the national unions had instituted a variety of strategies to deal with the identified challenges. The strategies were directed at securing the present membership and expanding union scope to cover workers in non-traditional union terrain, the informal economy and forging coalitions with other representative groups. Strategies for retaining members concentrated on improving internal structures to create better contact with members or expand their space for engaging with the unions. All these strategies pointed to union belief that union survival is better anchored on its relevance to members and an expanded representation of working people in Ghana. Thus coalitions focused on expanding the united front of organised labour and other civil society groups steering away from formalised cooperation with government or employers or political parties. But such coalitions have been issue focused and limited the expansion of the attention of 
the GTUC and its national affiliates into more social issues by making a consistent connection between the workplace, national and international struggle the focus of union strategic engagement. The analytical link has been very strong. What remains is the practical connection between the national and internal and how they impact union members in the three distinct spaces of membership as defined by their economic location in the formal or informal economy, by their gender or class position at the enterprise level. The emerging problems of membership in these three locations as unions set out to revitalise are discussed further in the next section.

\subsection{UNION RENEWAL AND INTRA UNION POWER DYNAMICS}

Earlier chapters reviewing specific renewal strategies targeting the three main forms of union members have noted how union membership provided opportunities and constraints at the same time. Here the operational spaces and their emerging power dynamics are discussed together to find forms of similarities and differences and their implications for the combined union membership. In bringing these specific issues of internal democracy together the questions begging for answers are how union responses to the emerging internal dynamisms shape their structures, processes and ideological orientation and finally what they hold in directing unions towards effective and sustainable revitalisation.

Intra union power dynamics opened up in the three membership spaces revolved around the definition of union membership and how it mediated access to union resources for pursuing specific concerns that members bring into their unions. The tensions such issues posed were raising questions about forms of union membership and how they impacted the manner in which the different members engaged and interacted with their unions. The forms of union membership offered differentiated access to union space and resources. Union space was circumscribed for each category of members thus providing peculiar forms of engagements.

Union constitution sets the framework for union membership delineating access to various forms of resources for the pursuit of interests. Such resources have been identified as power resources in that they facilitated members' ability to engage in struggles that emerge out of production relations and impinge on their rights as workers. How these power resources available in unions are accessed is informed by the nature of membership that union constitution grants. The fact of union membership grants access to unions as an aggregation of power for defending rights. Such rights can be bounded by the location of one's membership within the union structures.

Unions provide access to internal power resources in the form of direct protection and intervention. Avenues diverge based on the nature of production relations in which members operate and the social relations that mediate their union membership. Informal economy workers for example have the union membership mediated 
by their location in the informal economy, female union members have the union membership mediated by social gender relations both at the workplace and in the unions. The union membership of formal economy members was shaped by their positioning in the union hierarchy. These factors combine in diverse ways for the different categories of members. While for informal economy workers union dues posed the greatest problems for female and formal economy based workers it is the institutional location of the structures from which they accessed their unions.

The institutional locations of the structures in which members are located are determined by union constitution. The constitution of the GTUC and the national unions make a distinction between what is considered governing structures and administration and either consultation or operational structures. None of the structures holding members is designated governing structures. Yet this is where the union members are located. This fact affects their access to union power structures in that it makes their access dependent on other union structures like the governing or administrative structures. The structures in which union members were located lacked direct access to union decision-making, first because of the nature of the members occupying them and secondly, because of the institutional location of these structures in union hierarchy.

The constitutional definition of union membership as was shown in chapters five and eight was based on dues payment. This is a factor that limits the access of informal economy groups to full union membership. GAWU and ICU were providing solutions and TWU to a lesser extent. The GPRTU however provided the best solution to the definition of union membership by divorcing it from continuous payment of subscriptions. This was possible because of its welfare fund and ability to generate funds beyond dues payments. But welfare funds and the service orientation it gave to union functions, as discussions in the next section shows, produce its own problems for strengthening union political power.

The definition of union membership and the corresponding entitlements that were opened up affected members sense of union ownership which served as important tool for membership especially female membership, to access other union power tools. First of all, union ownership is dependent on an understanding of union roles and functions. Secondly it is dependent on membership right to use union structures and finally identify what structures are available. Availability of resources to provide union education was an important factor for the realisation of members' sense of union ownership. Enhanced knowledge in this case promoted the ability of members to engage struggles for their rights.

In the case of locals, union dues enhanced their membership rights but the possible utilisation of available funds was curtailed by constitutional provisions that gave governing structures and national officers direct control over the use of their funds. The payment, collection and disbursement of union finances formed contested ter- 
rains in union power dynamism. Because their autonomy was restricted, the locals, the only group of members with independent access to union finances, were hindered in terms of how they could use their subscriptions to engage their struggles in the workplace.

The mode of assigning membership and the institutional anchoring determined whether members could access their unions directly or through an intermediary. Women and informal economy members had to access their unions through Desk Officers. The direct access of locals and councils of labour (RCLs and DCLs) was subsumed under the supervisory role of the NEC, Secretary-General or General Secretary or through their regional representatives the Regional Secretaries or IROs. These arrangements introduced other actors into union power dynamics. The power of the Regional Secretary and IROs stemmed from the constitutionally mandated supervisory power, and sometimes greater control over resources. The power of union staff over members was mixed, sometimes serving to secure more union power. This was facilitated by their neutrality and control over union knowledge and sometimes resources. Their role as facilitators of access to union power resources however, created some dependency of members on the regional officers that was disempowering. The key role of IROs in negotiating CBAs for example gave them greater influence in the workplace than the leaders of the locals. So did the coordinating role of the Gender and Informal Economy Desk Officers. They also had better understanding of the unions. The devolution of power from elected representatives to union staff in the districts created forms of intra union tensions that were threatening to stifle initiative for independent action. Union structure and corresponding processes for engaging struggles gave leaders at the national level important roles as power tools. This gave them visibility and rendered them targets of union struggles as they became object for controlling unions. The possibility of cooption and their own pursuit of personal interests produced forms of intra union tensions.

Renewal strategies were producing contestations around union space and allocation of union resources for the development of political skills for independent action by union members. Funding was therefore an important power tool, first for enhancing individual capacity, and secondly for providing the basis for building solidarity. Union activities like meetings, forums, parades as well as trade union education cultivate a collective identity for expanding mobilisations potential of trade unions. To realise the power potential of members, trade unions have to provide a point of aggregation for rallying and nurturing members for forging a sense of unity and purpose. The absence of funds and resources made this a difficult task. The allocation of union resources was a contested terrain in that its absence stifled the potential of union members to use their structures. Various members realised the importance of funding. It was therefore posed as a constraint and was high on the list of suggestions for improving union support. 
Union membership is the foundation on which all forms of union power resources are based and opens out several avenues to union power resources for engaging working class struggles. When direct power resources are unavailable the fact of being a union member opens out to external agents for external resources. As mentioned in chapters five, six, seven and eight, NGOs, the press, local government leaders, politician and religious leaders were external actors enhancing union power resources. NGOs either provided direct resources or strengthened union political power through campaigns to change policy. Enterprise based unions or locals for example use their union membership to access external resources. So did the DCLs in the districts. Informal economy union members also found the fact of belonging to unions as opening up avenues that were hitherto closed. External actors were engaged in various degrees of attachment which either enhanced or constrained union power. NGOs and donors have enhanced members' awareness and improved their sense of union relevance. The press has been known also to facilitate union political power by courting public sympathy. Key figures like politicians, religious and traditional leaders, acted as external forces mediating union power by sometimes compromising unions through cooption or tempering of militancy to back legitimate demands.

Intra union power dynamics engaged with specific actors and in specific sites both internal and external. Union struggles were engaged at the national level where state policies and the egocentric interests of key persons at the workplace threatened workers' livelihoods and curtailed working rights. Within unions there were sites of contestation around resources and perceived entitlements that various members had. Union structures and institutional placement that the constitutions granted was also another site of struggle for members, especially for traditional trade union formal economy based members who were showing resentment at what they perceived was a hacking away of right to leadership positions by female and informal economy trade union members. Though in the choice of renewal strategies the GTUC and its national unions showed an awareness of the consideration that union power was better secured in the renewal of membership structures, leadership interests, constitutional and resource constraints were limiting the realisation of this potential. The contradictions produced by struggles over union resources were located in the manner in which union affairs were conceived of to starve structures where members were located and where union political power was strongest.

\subsection{OPERATIONAL ALTERATIONS OF UNION FUNCTIONAL TERRAIN}

Union functions were being continuously refined through efforts to improve relevance in order to expand union membership or retain members once organised. The functional expansion of union operations has occurred through servicing to maintain members and intervening to alter policy environment to sustain members' livelihood. Union political functions as a result have expanded by their moves to secure members' rights through engaging in policy or legislative reforms. Policy engage- 
ment and legislative interventions push union struggles beyond the workplace, travelling sometimes outside the community space into national and international realm. The GTUC's annual budget review is an example of policy engagement.

Servicing, as revealed in chapters five, six, seven and eight was an important tool for attracting and retaining trade union members. Servicing however has implication for union independence and autonomy as well as mobilising potential. Servicing was pulling unions towards a provisioning function and de-stressing their representation role. Though servicing helped to secure members and provided a sense of union relevance, as the experiences of GAWU, GPRTU and ICU revealed, its limits are in the dependency that it promotes and absence of the occasion for union members especially in the informal economy to test their political muscle for independent action to secure directly their needs. Servicing members through provisioning to satisfy short term needs arising out of policy failure, prevented unions from mobilising members to engage the real target and agents of their struggles. The benefit of the expansion in union membership size to union power was thus dissipated by failure to develop the political muscle through political mobilisation that points members to the fundamental premise of their problems. This is because as servicing rendered invisible the real source of workers' problems it diverted energies away from pursuing the real source of their struggles. Servicing prevented the development of political consciousness that could facilitate the grounds for building solidarity and mobilising members for political action. Thus the benefit of membership expansion as a possible source of union power was lost through the assumption of union functions that did not lead to a fundamental questioning of production relations that produced forms of exclusion and levels of insecurity in employment.

Servicing called union autonomy into question especially in situations where unions have to rely on external sources to fund their servicing programmes. Chapters five, six, seven and eight raised in passing the implications of external funding for the content of union agenda and a sense of membership ownership of their unions. The reliance on external funding introduced other actors into the trade union arena with implications for internal democracy because of forms of power resources that such actors brought into trade unions. Their impact on unions have been mixed as external funding had provided access to trade union education that had helped to broaden awareness. In the particular instance of gender democracy, female encounter with unions, as promoted through donor support, has been empowering in that it helped to deepen their sense of union ownership leading to greater involvement in union activities and a deeper commitment to their unions thus helping to tackle one important disempowering factor, apathy and lack of commitment to unions. However the sustainability of projects was severely curtailed by the drying up of donor funding. The availability of donor funding provides a route for trade union leadership to circumvent the need to erect efficient mechanisms for collecting and managing union subscriptions. It also introduced additional powerful actors in 
union internal power dynamism. Energies directed to securing donor attention and support could be diversionary. Equally diversionary are the requirements for fund disbursement reporting and tailoring union activities to match funding prerequisites. This is an area that requires further research. The failure on the part of unions to perceive such sources as short gap measures means that whatever benefits gained in the expansion of members was usually whittled away by the drying up of donor funds.

Locals through their demands on their unions were also forcing an extension of union functions beyond the workplace into members' homes and the community. The GPRTU and GAWU were pushing union functions into the communities and members homes. They were also more engaged with national policy through the need to protect the livelihoods of their members. This suggests that the more varied the background of union members the more likely trade unions were to expand their functions beyond the workplace into national policy and even beyond into the international arena. Representing informal economy workers was also moving the GTUC and its affiliates into policy engagement especially with local government authorities.

As a renewal strategy gender democracy was the weakest in forcing expansion of union functional terrain. Within unions there was a greater readiness to ease domestic responsibilities on women's participation in trade unions, but this effort had not been transferred into unions taking up similar concerns in the workplace or broader public life. Unions were failing to assume responsibility for leading a systematised campaign for addressing the burden of sexual division of labour on women's in ways that would relieve women and tackle the corresponding male involvement in domestic work. Gender democracy opened up heightened contestations around sexuality as a power tool within union power dynamics that unions were failing to address. This failure prevented the ability of female members to fully access their unions for the pursuit of their rights as workers. The councils of labour, the DCLs and RCLs were the strongest sites for expanding union functions through their link with other labour movements, NGOs, and local government institutions in the districts. They also operated as mobilisation sites because of their functions as points of aggregation of diverse union members that cut through all forms union membership differentiation.

\subsection{INTERNAL POWER DYNAMISM AND EFFECTIVE UNION REVITALISATION}

This study aimed to expand the debate about importance of internal factors to union renewal and to engage more specifically issues bordering on union internal democracy that emerge during revitalisation. In outlining union democracy as being about the ability of various members to utilise their unions in the pursuit of their interests as working people, it has been possible to distil the various forms and sites of struggles within unions. Factors affecting the utilisation of union power resources im- 
pacted group autonomy, coherence, sense of solidarity and mobilisation potential. Unions provided the potential for enhancing group coherence, clout and authority and increased bargaining but limited the complete utilisation of these potentials through constitutional arrangements that curtailed the autonomy of structures and limited available union spaces. None of the membership holding structures had constitutional autonomy. Resource provisioning was another constraining factor that inhibited full access to union power resources and in addition stalled the development of union capacity to realise the full potential of membership power.

Different forms of internal dynamics were opened up in three clusters of membership spaces. This was because being a trade union member did not grant automatic access to union power resources. Members have to connect with their unions and feel that they own the unions and have a right to make demands and use whatever resources their unions provided. This connection was an important tool that trade union education helped to secure especially for female and informal economy trade union members.

The realisation of the importance of unions in the working lives of members was however a powerful resource that was sustaining members. Members held a strong belief that trade unions served as an important tool in their struggle against the challenges of globalisation. It was this belief that facilitated union renewal in expanding and retaining membership. By recognising the importance and relevance of unions, even members most disillusioned about the response of their unions to their concerns were prepared to invest in securing the unions to better serve their needs. The most disillusioned were not planning to relinquish their union membership altogether, they were however considering joining existing unions or form new ones. Thus the option for existing unions provided by trade union pluralism was proving to be empowering for some locals and informal economy groups. Existing from their unions was however not a tool that women members had considered.

Intra union power game, especially among the three groups of members, that threatened trade union mobilisation and solidarity resulted from the inability of the GTUC and the national unions to forge cross group cohesion between the locals, women's committees and informal economy groups. Thus while within the various categories of union members there were forms of group coherence, they worked more towards greater intra group coherence and continued to stand alone with some remaining territorial. Male formal economy members were the most territorial about what they considered was an encroachment on their legitimate right to union leadership positions by female and informal economy trade union members. The councils of labour provided a platform of bringing together common concerns and harnessing the collective potential of the various categories of union members. In this way the GTUC and its national unions stood a better chance of benefiting from membership expansion based on servicing which formed a tenuous link in trans- 
forming union membership power into political power. Size expansion without an awareness of the true source of union struggle stands to mute union political edge.

How unions respond to emerging internal power dynamics stands to shape union structures, processes and ideological orientation and finally what these factors hold in directing unions towards effective and sustainable revitalisation. The test of revitalisation is the availability of union power tools and ability of members, irrespective of their background, to access and utilise such power tools for pursuing their cohered group interests. The search for solutions to differential access should be built on efforts to connect revitalisation strategies with the removal of barriers to union power tools. Such a connection will allow for the transformation of intra union sites of contestation into sites of solidarity, mobilisation and autonomy. Issuing out of all that should be combined efforts directed at consolidating union power for meeting better the challenges of globalisation. 


\section{REFERENCES}

Abugre, C. (2001). Still Sapping the Poor: A Critique of IMF Poverty Reduction Strategies. London: World Development Movement.

Addison, J. T., \& Schnabel, C. (2003). Introduction. In J. T. Addison, \& C. Schnabel, International Handbook of Trade Unions (pp. 1-12). Cheltenham: Edward Elgar Publishing Limited.

Adu-Amankwah, K. (1990). The State, Trade Unions and Democracy in Ghana, 1982 to 1990. The Hague: The Institute of Social Studies.

Adu-Amankwah, K., \& Tutu, K. (1997). Ghana; Going Beyond Politics. In G. Kester, Trade Unions and Sustainable Democracy in Africa. Aldershop: Ashgate.

African Labour Research Network. (2004). Gender and Labour Market Liberalisation in Africa. NALEDI.

Akabzaa, T. (2001). Research for Advocacy on Issues on Mining and the Environment in Africa: A Case Study from the Tarkwa Mining District in Ghana. In T. W. Africa, Mining, Development and Social Conflicts in Africa (pp. 143-153). Accra: Third World Network Africa.

Aksikas, J. (2007). Prisoners of Globalization: Marginalirty, Community and the New Informal Economy in Morocco. Mediterranean Politics, 12 (2), 249-262.

Albarracín, J. (2000). Neoliberal Employment Policies: The Case of Spain. International Journal of Political Economy , 30 (2), 56-81.

Alenjandro, C. (2002). The Class Politics of Globalisation. In M. Rupert, \& H. Smith, Historical Materialism and Globalization (pp. 191-). London: Routlege.

Andræ, G., \& Beckman, B. (1998). Union Power in the Nigerian Textile Industry: Labour Regime and Adjustment. Uppsala: Nordiska Afrikainstitutet.

Arthiabah, P. B., \& Mbiah, H. T. (1995). Half a Century of Toil, Trouble and Progress: the History of the Trades Union Congress of Ghana. Accra: Gold Type Press Publications Limited.

Arthiabah, P. (1974). The Politics of the Second Quadrennial Conference of the Ghana Trades Union Congress. Legon Observer .

Aryeetey, E., \& Goldstein, M. (2000). Ghana Social Reform in Africa. In R. S. Development, Morales-Gomez, Necla Tchirgi; Moher, Jennifer L (pp. 9-43). Dakar: International Development Research Centre.

Baah. (n.d). Trade Unions and Working Conditions in Ghana (1980s to 1990s). Unpublished Report.

Baah, A. Y. (2006). Public Sector Salary Reform: Critical Issues to Consider. Trades Union Congress: Policy Bulletin, 2 (1), 12-17.

Baah, A. Y. (2001). The Economy of Ghana. In A. Y. Baah, The Social Dimension of Structural Adjustment (pp. 1-11). Accra: TUC (Ghana).

Behrens, M., Hamann, K., \& Hurd, R. (2004a). Conceptualizing Labour Union Revitalization. In C. Frege, \& J. Kelly, Varieties of Unionism: Strategies for Union Revitalization in a Globalising Economy (pp. 11-29). Oxford: Oxford University Press.

Behrens, M., Hurd, R., \& Waddington, J. (2004). How Does Restructuring Contribute to Union Revitalisation? In F. C, \& J. Kelly, Varieties of Unionism: Strategies for Union Revitalisation in a Globalizing Economy. Oxford: Oxford University Press.

Beneria, L. (2001). Shifting the Risk; New Employment Patterns, Informalization and Women's Work. International Journal of Politics, Culture, and Society, 15 (1), 27-53.

Boafo-Arthur, K. (1999). Structural Adjustment Programs (SAPS) In Ghana: Interrogating PNDC's Implementation. West Africa Review , 1 (1). 
Bowles, P. (2010). Globalization's Problematic for Labour: Three Paradigms. (P. Bowles, \& J. Harris, Eds.) Global Labour Journal , 1 (1), 12-31.

Briskin, L. (2006). Victimisation and Agency: the Social Construction of Union Women's Leadership. Industrial Relations Journal , 37 (4), 350-378.

Briskin, L., \& McDermott, P. (1993). Women Challenging Union: Democracy, and Militancy . London: University of Toronto Press.

Britwum, A. O. (2000). Female Representation and Participation in Trade Unions . In P. Agbesinyale, Democratic Workers' Participation for Economic and Social Development: the Case of Ghana (pp. 102-122). Accra: TUC-UCC/APADEP.

Britwum, A. O. (2008). Review of GTUC Work in the Informal Economy. GTUC-LO/FTF-Denmark.

Britwum, A. O. (2008). Review of ICU's Work in the Informal Economy. Accra: ICU-LO/FTF-Denmark.

Britwum, A. O. (2007a). The Gender of Trade Union Democratic Participation. In G. Kester, Trade Unions and Workplace Democracy in Africa (pp. 227-251). Aldershot: Ashgate.

Britwum, A. O. (2009). The Gendered Dynamics of Production Relations in Ghanaian Coastal Fishing. Feminist Africa, 12 (2), 69-85.

Britwum, A. O. (2007). The Ghana Trades Union Congress: Sixty Years of Promoting Workers' Rights. Accra: Ghana Trades Union Congress.

Britwum, A. O., \& Martens, P. (2008). The Challenge of Globalization, Labor Market Restructuring and Union Democrarcy in Ghana. African Studies Quarterly, 10 (2-3).

Britwum, A. O., Ghartey, N. K., \& Agbesinyale, P. (2006). Organising Labour in the Informal Sector: the Case of Rural Agriculture in Ghana. Accra: Ghana Universities Press.

Brueggemann, J., \& Brown, C. (2000). Strategic Labour Organising in the Era of Industrial Transformation: A Comparative Historical Analysis of Unionisation in Steel and Coal, 1870 and 1916. Review of Radical Political Economics, 32 (4), 541-576.

Bryceson, D. F. (1995). African Women Hoe Culitivators: Speculative Origins and Current Enigmas. In D. F. Bryceson, Women Wielding the Hoe: Lessons from Rural Africa for Feminist Theory and Development Practice (pp. 3-22). Oxford: Berg Publishers.

Buckman, G. (2004). Globalization: Tame it or Scrap it? Mapping the Alternatives of the Anti-Globalization Movement. London: Zed Books.

Burnham, P. (2002). Class Struggles, States and Global Circuits of Capital. In M. Rupert, \& H. Smith, Historical Materialism and Globalization. London: Rutledge.

CBMWU. (2000). Constitution Rules and Bye-Laws of the Construction and Building Materrials Workers' Union of the Trades Union Congress (Ghana). Accra: Construction and Building Materials Workers' Union.

Colgan, F., \& Ledwith, S. (2000). Diversity, Identities and Strategies of Women Trade Union Activists. Gender, Work and Organization, 7 (4), 242-257.

Cook, A. H., Lorwin, V. R., \& Daniels, A. K. (1992). The Most Difficult Revolution: Women and Trade Unions. London: Cornell University Press.

Cooke, F. L. (2006). Informal Employment and Gender Implications in China: the Nature of Work and Employment Relations in the Community Service Sector. The International Journal of Human Resource Management, 17 (8), 1471-1487.

Costello, C., \& Stone, A. J. (2001). The American Woman 2001-2002: Getting to theTop. London: Oxford University Press.

Cowan, E. A. (1960). Evolution of Trade Unionism in Ghana. Accra: TUC Ghana.

Cox, M. (2002). The Search for Relevance: Historical Materialism after the Cold War. In M. Ruper, \& H. Smith, Historical Materialism and Globalization (pp. 59-). London: Routlege.

Creese, G. (1999). Contracting Masculinity: Gender Class, Race in a White Collar Union 1944-1994. London: Oxford University Press.

Crisp, J. (1984). The Story of An African Working Class: Ghanaian Miners Struggles, 1870-1980. London: Zed Books.

Curtin, J. (1999). Women and Trade Unions: A Comparative Perspective. Aldershot: Ashgate.

Dasgupta, S. (2003). Structural and Behavioural Characteristics of Informal Service Employment: Evidence from a Survey in New Delhi. Journal of Development Studies , 39 (3), 51-80.

Davies, M. (2004). Planet of Slumes: Urban Involution and the Informal Proletariat. New Left Review , 26.

Deslippe, D. A. (2000). "Rights not Roses" Unions and the Rights of Working Class Feminism, $1945-80$. Chicago: University of Illinois Press. 
Devey, R., Skinner, C., \& Valodia, I. (2003). HRD Review. Retrieved September 19, 2008, from http://hrdreveiw.hsrc.ac.za

Duncan, B. A. (2004). Women in Agriculture in Ghana. Accra: Friedrich Ebert Foundation.

Elson, D. (1999). Labor Markets as Gendered Institutions: Equality, Efficiency and Empowerment Issues. World Development, 27 (3), 611-627.

Fairbrother, P. (1990). The Contours of Local Trade Unionism in a Period of Restructuring. In P. Fosh, \& E. Heery, Trade Unions and their Members: Studies in Union Democracy and Organisation. London: Macmillan (British Sociology Association).

Fine, B., \& Boateng, K. (2000). Labour and Employment under Structural Adjustment. In E. Aryeeter, J. Harrigan, \& M. Nissanke, Economic Reforms in Ghana: The Miracle and the Mirage. Accra: Woeli Publishing Services.

Flick, U. (2007). Managing Quality in Qualitative Research . London: SAGE Publications.

Flynn, M., Brewster, C., Smith, R., \& Rigby, M. (2004). Trade Union Democracy: the Dynamics of Different Forms. In M. Harcourt, \& G. Wood, Trade Unions and Democracy: Strategies and Perspectives (pp. 319351). Manchester: Manchester University Press.

Frege, C., \& Kelly, J. (2004). Union Strategies in Comparative Context. In C. Frege, \& J. Kelly, Varieties of Unionism: Strategies for Union Revitalisation in a Globalizing Economy (pp. 31-44). Oxford: Oxford University Press.

GAWU. (2008). The Constitution of the General Agricultural Workers' Union. Accra: The General Agricultural Workers' Union.

George, A. L., \& Bennett, A. (2005). Case Studies and Theory Development in Social Sciences. Cambridge: MIT Press.

George, A. L., \& Bennett, A. (2005). Case Studies and Theory Development in Social Sciences. Cambridge: MIT Press.

Ghana Mineworkers' Union of GTUC. (2007). Constitution and Internal Regulations. Accra: GMWU of GTUC.

Ghana Statistical Service. (2002). Population and Housing Census. Accra: GSS.

Gibbs, G. (2007). Analysing Qualitative Data . London: Sage Publications.

Gokel, A. F., \& Vormawor, D. (2004). FES Trade Union Country Reports: The Case of Ghana. Accra: Friedrich Ebert Stiftung.

Gough, K. V., Tipple, A. G., \& Napier, M. (2003). Making a Living in African Cities: The Role of HomeBased Enterprises in Accra and Pretoria. International Planning Studies , 8 (4), 253-277.

GPRTU of GTUC. (2007). 2007 Constitution. Accra: GPRTU.

Graham, Y. (2001). Changing the United Brotherhood: An Analysis of the Gender Politics of the Ghana Trades Union Congress. In D. Tsikata, Gender Training in Ghana: Politics, Issues and Tools (pp. 293320). Accra: Woeli Publishing Services.

Graham, Y. (1989). From GTP to Assene: Aspects of Industrial Working Class Struggles in Ghana 19821986. In E. Hansen, \& K. A. Ninsin, The State, Development and Politics in Ghana (pp. 43-72). Dakar: CODESRIA.

Grint, K. (1991). The Sociology of Work: An Introduction. Cambridge: Polity Press.

Grix, J. (2004). The Foundations of Research. Hampshire: Palgrave.

GTUC. (2008). Policies for the Quadrennial 2008-2012. Accra: Ghana Trades Union Congress.

Gyimah-Boadi, E., \& Jeffries, R. (2000). The Political Economy of Reform. In E. Aryeetey, J. Harrigan, \& M. Nissanke, Economic Reforms in Ghana: The Miracle and Mirage (pp. 32-50). Accra: Woeli Publishing Services.

Harcourt, M. (2004). Neo-Liberal Reforms and Accords: Are They Compatible with Democracy? In M. Harcourt, \& W. Geoffrey, Trade Unions and Democracy: Strategies and Perspectives (pp. 40-61). Manchester: Manchester University Press.

Harrod, J., \& O'Brien, R. (2002). Organised Labour and the Global Political Economy. In J. Harrod, \& R. O'Brien, Global Unions? Theory and Strategies of Organised Labour in the Global Political Economy (pp. 328). London: Routledge.

Haynes, J. (2005). Comparative Pollitics in a Globalizing World. Cambridge: Polity Press.

Healy, G., \& Kirton, G. (2000). Women, Power and Trade Union Government in the UK. British Journal of Industrial Relations , 38 (3), 343-360. 
Heery, E., \& Fosh, P. (1990). Whose Union: Power and Bureaucracy in the Labour Movement. In P. Fosh, \& E. Heery, Trade Unions and their Members: Studies in Union Democracy and Organisation (pp. 1-28). London: British Sociological Association.

Hensman, R. (2002). Organisational Strategies of Women Workers in India. In F. Clogan, \& S. Ledwith, Gender, DIversity and Trade Unions: International Perspectives (pp. 95-112). London: Routledge.

Hoogvelt, A. M. (2001). Globalization and the Postcolonial World: the New Political Economy of Development. Baltimore MD: John Hopkins University Press.

Hormeku, T. (1998). The Transformation and Development of the Informal Sector and the Role of the Trade Unions. OATUU/ILO/ETUF Seminar on Trade Unions and the Informal Sector (pp. 4-6). Cairo: OATUU/ILO/ETUF.

Hurd, R. W. (2004). The Rise and Fall of the Organizing Model in the US. In M. Harcourt, \& G. Wood, Trade Unions and Democracy: Strategies and Perspectives (pp. 191-210). Manchester: Manchester University Press.

Hyman, R. (1999). Imagined Solidarities: Can Trade Unions Resist Globalization? . In P. Leisink, Globalization and Labour Relations (pp. 94-114). Cheltenham: Edward Elgar.

Hyman, R. (1978). Marxism and the Sociology of Trade Unionism. In T. Clarke, \& L. Clemento, Trade Unions Under Capitalism. Glasgow: William Collins and Co Limited.

Hyman, R. (2001). Trade Union Research and Cross-National Comparison. European Journal of Industrial Relations , 7 (2), 203-232.

Hymer, S. H. (1970). Economic Forms in Pre-Colonial Ghana. The Journal of Economic History, 30 (1), 33-50.

ILO. (2004). A Fair Globalization: The Role of the ILO. International Labour Conference, 92nd Session, World Commission on the Social Dimension of Globalization. Geneva: ILO.

Industrial and Commercial Workers' Union . (2003). Constitution, Rules and Bye-Laws. Accra: ICU Ghana.

ISSER/DPPC. (1996). Women in Public Life in Ghana. Accra: DFID.

Jeffries, R. (1978). Class, Power and Ideology in Ghana: The Railwaymen of Sekondi. London: Cambridge University Press.

Jelle, V. (2003). Unions and Unionism around the World. In J. T. Addison, \& C. Schnabel, International Handbook fo Trade Unions (pp. 366-406). Cheltenham: Edward Elgar Publishing Limited.

Jenkins, R. (2004). Globalisation, Production, Employment and Poverty: Debates and Evidence. Journal of International Development, 16 (1), 1-12.

Kelly, J., \& Frege, C. M. (2004). Conclusions: Varieties of Unionism. In C. M. Frege, \& J. Kelly, Varieties of Unionism: Strategies for Union Revitalisation in a Globalizing Economy (pp. 181-195). Oxford: Oxford University Press.

Kester, G. (2007). Trade Unions and Workplace Democracy in Africa. Aldershot: Ashgate.

Kester, G., \& Sidibe, O. O. (1997). Trade Unions it is Your Turn. In G. Kester, \& O. O. Sidibe, Trade Unions and Sustainable Democracy in Africa (pp. 1-17). Aldershot: Ashgate.

Klein, M. v. (2003, Spring). The Widows of the Gasworks: Gendered Path Dependency and the Early Dutch Welfare State. Social Politics .

Knight, B., Chigudu, H., \& Tandon, R. (2002). Reviving Democracy: Citizens at the Heart of Governance. London: Earthscan.

Koch-Baumgarten, S. (2002). Changing Gender Relations in German Trade Unions: From 'Workers' Patriarchy' to Gender Democracy? In F. Cogan, \& S. Ledwith, Gender, Diversity adn Trade Unions: Intenational Perspectives (pp. 132-153). London: Routledge.

Konings, P. (2003). Organised Labour and Neo-Liberal Economic and Political Reforms in West and Central Africa. Journal of Contempory African Studies , 21 (3), 447-471.

Kraus, J. (2007). Conclusion: Trade Unions and Democratization in Africa. In J. Kraus, Trade Unions and the Coming of Democracy in Africa. New York: Pelgrave-Macmillan.

Kraus, J. (1988). The Political Economy of Trade Union-State Relations in Radical and Populist Regimes in Africa . In R. Southall, Labour and Unions in Asia and Africa: Contemporary Issues. New York: St Martins Press.

Kraus, J. (2007). Trade Unions, Democratization and Economic Crisis in Ghana. In J. Kraus, Trade Unions and the Coming of Democracy in Africa. New York: Pelgrave-Macmillan.

Kumar, P., \& Schenk, C. (2004). Institutional and Conceptual Perspectives on Union Renewal. CRIMT International Colloquium on Union Renewal. Montreal: CRIMT. 
Laffey, M., \& Kathryn, D. (2002). A Flexible Marxism for Flexible Times: Globalization and Historical Materialism. In M. Ruper, \& S. Hazel, Historical Materialism and Globalization (pp. 90-). London: Rutledge.

Lambert, R. (2002). Labour Movement Renewal in the Era of Globalization: Union Responses in the South. In H. Jeffery, \& R. O'Brien, Global Unions? The Theories and Strategies of Organised Labour in the Global Political Economy (pp. 185-203). London: Routledge.

Ledwith, S. (2009). Encounters Between Gender and Labour Policies: Towards an Inclusive Trade Union Democracy. In M. F. Ozbilgin, Equality, Diversity adn Inclusion at Work: Theory and Scholarship (pp. 272-287). Cheltelham: Edward Elgar Publishing.

Ledwith, S. (2006). Feminist Praxis in a Trade Union Gender Project. Industrial Relations Journal , 37 (4), 379 399.

Ledwith, S. (2006). The Future is Female? Gender, Diversity and Global Labour Solidarity. In C. Phelan, The Future of Organised Labour: Global Perspectives. (pp. 91-134). Oxford: Peter Lang.

Ledwith, S. (2009). Vive la Différence? Women and Trade Unions in Britain. Revue Française de Civilisation Britannique, XV (2), 87-112.

Ledwith, S., Colgan, F., Joyce, P., \& Hayes, M. (1990). The Making of Women Trade Union Leaders. Industrial Relations Journal , 21 (2), 112-125.

Ligthelm, A. A. (2005). Informal Retailing through Home-Based Micro-Enterprises: The Role of Spaza Shops. Development Southern Africa, 22 (2), 199-214.

Linden, M. v. (2008). Workers of the World: Essays Toward a Global Labor History. Leiden: Brill.

Lyons, M., \& Snoxell, S. (2005). Creating Urban Social Capital: Some Evidence from Informal Traders in Nairobi. Urban Studies , 42 (7), 1077-1097.

MacInnes, J. (1990). The Future of This Great Movement of Ours. In P. Fosh, \& E. Heery, Trade Unions and their Members: Studies in Union Democracy and Organisation (pp. 206-232). London: Macmillan (British Sociological Association).

Manda, D. K., \& Sen, K. (2004). The Labour Market Effects of Globalization in Kenya. Journal of International Development, 16 (1), 29-43.

Matsebula, M. S. (1996). The Urban Informal Sector: a Historical and Structural Analysis with Special Reference to Swaziland. (G. Mhone, Ed.) Harare: SAPES Books.

McBride, A. (2001). Gender Democracy in Trade Unions. Aldershot: Ashgate.

McMicheal, P. (2001). Revisiting the Question of the Transnational State: A Comment on William Robinson's "Social Theory and Globalisation". Theory and Society , 30, 201-210.

Michels, R. (1959). Political Parties: A Sociological Study of the Oligarchical Tendencies of Modern Democracies. Gloucester: Peter Smith.

Morales-Gomez, Tschirgi, N., \& Moher, J. L. (2000). Reforming Social Policy: Changing Perspectives on Sustainable Human Development. Dakar: International Development Research Centre.

Mozhayev, V. (1990). New Political Thinking and the World Trade Union Movement. Moscow: Profizdat.

Munck, R. (2002). Globalzation and Labour: The New "Great Transformation". London: Zed Books.

Necla, T. (2000). Introduction: The Paradox of Development. In Morales-Gomez, N. Tschirgi, \& J. L. Moher, Reforming Social Policy: Changing Perspectives on Sustainable Human Development (pp. 1-8). Dakar: International Development Research Centre.

Ninsin, K. A. (1989). Introduction: Thirty-Seven Years of Development Experience. In E. Hansen, \& K. A. Ninsin, The State Development and Politics in Ghana (pp. 1-12). Dakar: CODESRIA.

Ninsin, K. A. (1989). State Capital and Labour Relations, 1961-1987. In E. Hansen, \& K. A. Ninsin, The State Development and Politics in Ghana (pp. 15-42). Dakar: CODESRIA.

Ninsin, K. A. (1991). The Informal Sector in Ghana's Political Economy. Accra: Freedom Publications.

Nugent, P. (1995). Big Men, Small Boys and Politics in Ghana: Power, Ideology and the Burden of History, 1982-1994. Accra: Asempa Publishers.

Ofei-Aboagye, E. (2001). Strutural Adjustment and Women in Ghana. In A. Y. Baah, The Social Dimension of Structural Adjustment (pp. 89-124). Accra: GTUC/ICFTU-AFRO.

Önder, N. (1998). Intergrating with the Global Market: The State and the Crisis of Political Representation. International Journal of Political Economy, 28 (2), 44-84.

Overton, J. (2000). Academic populists, the informal economy and those benevolent merchants: Politics and Income Security Reform in Newfoundland. Journal of Peasant Studies , 28 (1), 1-54.

Panford, K. (1994). African Labour Relations and Workers' Rights: Assessing the Role of the International Labour Organization. London: Greenwood Press. 
Panford, K. (1996). The Labor Movement, Politics and Democracy in Ghana (1985-1996). Methodological Seminars and Special Studies on Social Movement in Africa. Dakar, Senegal: CODESRIA.

Panford, K. (1996). The Labour Movement, Politics and Democracy in Ghana (1985-1996). Paper Presented at CODESRIA Methodological Seminars and Special Studies on Social Movement in Africa. Dakar, Senegal.

Parker, J. (2009). Women's Collectivism in Context: Women's Groups in UK Trade Unions. Industrial Relations Journal , 40 (1), 78-97.

Peattie, L. (1987). An Idea in Good Currency and how it Grew: The Informal Sector. World Development , 15 (7), 851-860.

Philip, K. (2005). Rural Enterprise: Work on the Margins. In E. Webster, \& K. Von Holdt, Beyond the Apartheid Workplace: Studies in Transition (pp. 361-386). University of KwaZulu-Natal Press.

Poole, M. (1981). Theories of Trade Unionism: A Sociology of Industrial Relations. London: Rutledge and Kegan Paul.

Public Agenda. (2008, December 22). Floodgates Opened to Foreign Textiles. Public Agenga .

Ramaswamy, E., \& Schiphorst, F. B. (1998). Human Resource Management, Trade Unions and Empowerment: Two Cases from India. Working Paper Series .

Rathbone, R. (2003). Businessmen in Politics: Party Struggle in Ghana, 1945-57. Journal of Development Studies , 391-403.

Reddy, M. (2007). Modelling Poverty Dimensions of Urban Informal Sector Operators in a Developing Economy. The European Journal of Development Research , 19 (3), 459-479.

Rees, T. (1990). Gender, Power and Trade Union Democracy. In P. Fosh, \& E. Heery, Trade Unions and their Members: Studies in Union Democracy and Organisation (pp. 177-205). London: Macmillan (British Sociological Association).

Roper, I. (2004). Trade Unions and Democracy: Can the 'Third Way' Recast the Link? In M. Harcourt, \& G. Wood, Trade Unions and Democracy: Strategies and Perspectives (pp. 82-104). Manchester: Manchester, University Press.

RoyChowdhury, S. (2003). Public Sector Restructuring and Democracy: The State, Labour and Trade Unions in India. (F. Cass, Ed.) The Journal of Development Studies , 39 (3), 29-50.

Rupert, M., \& Smith, H. (2002). Editor's Introduction. In M. Rupert, \& H. Smith, Historical Materialism and Globalisation (pp. 1-13). London: Rutledge.

Samers, M. (2005). The Myopia of "Diverse Economies", or a Critique of "Informal Economy". Antipode , 37 (5), 875-886.

SAPRIN. (2004). Structural Adjustment: The SAPRI Report. The Policy Roots of Economic Crisis, Poverty and Inequality. London: Zed Books.

Sayce, S., Greene, A.-m., \& Ackers, P. (2006). Small is Beautiful? The Development of Women's Activism in a Small Union. Industrial Relations Journal , 37 (4), 400-414.

Servais, J.-M. (2004). Globalisation and decent work policy: Reflections Upon a New Legal Approach. International Labour Review , 143 (1-2), 15-207.

Shillington, K. (1992). Ghana and the Rawlings Factor. London: The Macmillan Press.

Shively, P. W. (1991). Power and Choice: An Introduction to Political Science. London: MacGraw Hill Inc.

Smith, A., \& Stenning, A. (2006). Beyond Household Economies: Articulations and Spaces of Economic Practice in Postsocialism. Progress in Human Geography , 30 (2), 190-213.

Steele, M. (1990). Changing the Rules: Pressures on Trade Union Constitutions. In P. Fosh, \& E. Heery, Trade Unions and their Members: Studies in Union Democracy and Organisation (pp. 52-74). London: Macmillan (British Sociological Associaiton).

Streeck, W., \& Hassel, A. (2003). Trade Unions as Political Actors. In J. T. Addison, \& C. Schnabel, International Handbook of Trade Unions (pp. 335-265). Cheltenham: Edward Elgar Publishing Limited.

Sutcliffe, B. (2002). How Many Captialisms? Historical Materialism in the Debates about Imperialism and Globablization. In M. Rupert, \& H. Smith, Historical Materialism and Globalization. London: Rutledge.

Sutcliffe, B., \& Glyn, A. (1999). Still Underwhelmed: Indicators of Globalisation and Their Misinterpretation. Review of Radical Political Economics , 31 (1), 111-132.

Teschke, B., \& Christian, H. (2002). The Dialetic of Globalisation: A Critique of Social Constructivism. In M. Rupert, \& H. Smith, Historical Materialism and Globalisation (pp. 165-). London: Routledge.

Todaro, M. (1994). Economic Development. London: Longman.

Tsikata, D. (2001). The Politics of Policy-Making: A Gender Perspective. In D. Tsikata, Gender Training in Ghana (pp. 321-353). Accra: Woeli Publishers.

TUC. (2001). Membership Survey: Preliminary Report. Accra: TUC Ghana. 
TUC. (1997). The Women's Desk of the TUC (Ghana). Accra: TUC Ghana.

Turner, L. (2004). Why Revitalize? Labour's Urgent Mission in a Contested Global Economy. In C. M. Frege, \& J. Kelly, Varieties of Unionism: Strategies for Union Revitalization in a Globalizing Economy (pp. 1-10). Oxford Universty Press.

Undy, R., \& Martin, R. (1984). Ballots and Trade Union Democracy. Oxford: Basil Blackwell.

Von Holdt, K., \& Webster, E. (2005). Work Restructuring and the Crisis of Social Reproduction: A Southern Perspective. In E. Webster, \& K. Von Holdt, Beyond the Apartheid Workplace: Studies in Transition (pp. 1-40). University of KwaZulu-Natal Press.

Voss, K., \& Sherman, R. (2000). Breaking the Iron Law of Oligarchy: Union Revitalisation in the American Labour Movement. American Journal of Sociology (AJS) , 106 (2), 303-349.

Walton, J. (1991). Women Shop Stewards in a County Branch of NALCO. In N. Redclift, \& S. M. T, Working Women: International Perspectives on Labour and Gender Ideology (pp. 149-171). London: Routledge.

Webster, E. (2005). New Forms of Work and the Representational Gap: A Durban Case Study. In E. Webster, \& K. Von Holdt, Beyond the Apartheid Workplace: Studies in Transition (pp. 387-405). University of KwaZulu-Natal Press.

Williams, C. C. (2008). "A Critical Evaluation of Competing Representations of the Relationship Between Formal and Informal Work". Community Work and Family , 11 (1), 105-124.

Williams, C. C. (2005). "Formalising the Informal Economy: The Case for Local Initiatives". Local Governemnt Studies , 31 (3), 225-349.

Williams, C. C., \& Round, J. (2007). Re-thinking the Nature of the Informal Economy through Ukraine. International Journal of Urban and Regional Research, 31 (2), 425-441.

Wood, G. (2004). Conclusion: Broadening Democracy and the Labour Movement. In M. Harcourt, \& G. Wood, Trade Union and Democracy: Strategies and Perspectives (pp. 397-412). Manchester: Manchester University Press.

Wood, G. (2004). Engagement or disengagement? Unions and a New Politics. In M. Harcourt, \& G. Wood, Trade Unions and Democracy: Strategies and Perspectives (pp. 377-396). Manchester: Manchester University Press.

Wood, G. (2004). Introduction - Trade Unions and Democracy: Possibilities and Contradictions. In M. Harcourt, \& G. Wood, Trade Unions and Democracy: Strategies and Perspectives (pp. 1-18). Manchester: Manchester University Press.

Wood, G. (2004). Trade Unions and Theories of Democracy. In M. Harcourt, \& W. Geoffrey, Trade Unions and Democracy: Strategies and Perspectives (pp. 19-40). Manchester: Manchester University Press.

Work, A. L. (2002). Production and Social Relations: Repositioning the firm in the International Political Economy. In H. Jeffrey, \& R. O'Brien, Global Unions? The Theories and Strategies of Organised Labour In the Global Political Economy (pp. 29-48). London: Routledge.

World Bank . (2004). World Bank Development Report. Washington DC: The World Bank.

Yin, R. K. (2008). Case Study Research: Design and Methods of Applied Social Research Methods Series (4 ed.). London: Sage Publications.

Young, K. (1993). Planning Development with Women: Making a World of Difference. London: Macmillan. 


\section{TRADE UNION DOCUMENTS CONSULTED}

\section{GTUC Documents}

Project Document; Capacity Building in TUC: Ghana TUC Ghana - LO/FTF $1^{\text {st }}$ July 2005

Meeting the Challenges of the Quadrennial: 2004-2008-Medium Term Policies of the Ghana Trades Union Congress; August 2004

Project Document GTUC-LO/FTF; 2005

GTUC-LO/FTF - Capacity Building Project-Annual Report for 2006; Feb 2007 GTUC Policies

\section{ICU Documents}

Development Associates A/S, Planning, Monitoring and Evaluation: Evaluation of Three Projects in Ghana Final: Synthesis Report; August 2004.

ICU/KAD/LO-FTF: Organising Workers in the Informal Sector; Ghana Evaluation Study, Final Report, August 2004.

LO/FTF Council, 2003: Profile of the Labour Market and Trade Unions in Ghana.

TUC, Ghana. June 2001. Membership Survey: Preliminary Report.

\section{GAWU Documents}

Terminal report of the Self-Employed Rural Workers Project (SERWP) of GAWU October 2003

Report on a 3-Day Orientation/Sensitization Workshop on 'Consolidating the Organisation of Self-Employed Rural Workers within the Trade Unions' $2-4^{\mathrm{TH}}$ September 1998; Sunyani, Brong Ahafo Region

Report of the National Executive Council on The Activities of GAWU to the $6^{\text {th }}$ Quadrennial Delegates Conference at the Catholic Pastoral Training and Social Cen- 
tre; Sunyani, October 1999 Conference theme: 'Charting a New Trade Union Path into the Twenty First Century'

Report of The National Executive Council on The Activities of GAWU to the $7^{\text {th }}$ Quadrennial Delegates Conference at Akuafo Hall Legon-Accra; August, 2003 Conference theme 'Organizing for Rural Poverty Alleviation And Sustainable Employment $^{\prime}$ 



\section{APPENDIX A: \\ RESEARCH PARTICIPANTS - INDIVIDUAL INTERVIEWS}

1. The Secretary-General

2. Deputy Secretary-General

3. General Secretaries or their Representatives of the following national unions:

a. CBMWU

b. CTPCWU

c. CWU

d. GAWU

e. GMWU

f. GPRTU

g. HSWU

h. ICU-(Interim Management Committee)

i. LGWU

j. MDU

k. NUS

1. PSWU

m. PUWU

n. TEWU

o. TWU

4. Union Officers

i. GPRTU-Field Officer

ii. MDU-Head of Administration

iii. MDU-Deputy Head of Administration

iv. NUS-Administrator

v. PSWU-Senior Admin Secretary

vi. PUWU- Research Officer

5. Heads of following GTUC departments
a. Organisation
b. Policy and Research
c. Education 
d. Deputy Head-Administration

e. Gender Desk Officer (Past and current)

6. Informal economy desk officers in GTUC and the National Unions

i. GTUC (Past and Present)

ii. GAWU

iii. ICU

iv. LGWU

v. PSWU

vi. TWU

7. Gender/Women Desk Officers
a. ICU-Gender Desk Officers
b. GAWU-Gender Desk Officers
c. GMWU-Gender Desk Officers
d. HSWU-National Women's Coordinator
e. HSWU-Head of Women's Desk

8. Regional officers of the GTUC and identified National Unions

\begin{tabular}{|l|c|c|c|c|c|c|c|c|}
\hline Region & GTUC & ICU & GAWU & CBMWU & MDU & GPRTU & GMWU & Total \\
\hline $\begin{array}{l}\text { Greater } \\
\text { Accra }\end{array}$ & 1 & 1 & 1 & - & 1 & - & 1 & \\
\hline Eastern & 1 & 1 & 1 & 1 & - & - & - & 4 \\
\hline Central & 1 & 1 & 1 & 1 & - & 1 & - & 5 \\
\hline Ashanti & 1 & 1 & 1 & 1 & - & 1 & - & 5 \\
\hline Western & 1 & 1 & 1 & 1 & 1 & 1 & 1 & 7 \\
\hline Northern & 1 & 1 & 1 & 1 & - & 1 & - & 5 \\
\hline Total & $\mathbf{6}$ & $\mathbf{6}$ & $\mathbf{6}$ & $\mathbf{5}$ & $\mathbf{2}$ & $\mathbf{4}$ & $\mathbf{2}$ & 31 \\
\hline
\end{tabular}




\section{APPENDIX B: RESEARCH PARTICIPANTS-GROUP INTERVIEWS}

1. Executives of RCLs and DCLs; RWC and DWCs

\begin{tabular}{|l|l|l|l|l|l|}
\hline Region & RC & RWC & DCL & DWC & Total \\
\hline $\begin{array}{l}\text { Greater } \\
\text { Accra }\end{array}$ & - & Greater Accra & $\begin{array}{l}\text { Ga West } \\
\text { Tema }\end{array}$ & Ga West & 4 \\
\hline Eastern & Eastern & Eastern & $\begin{array}{l}\text { New Juaben } \\
\text { Akuapem South }\end{array}$ & New Juaben & 5 \\
\hline Central & Central & Central & $\begin{array}{l}\text { Mfantiman } \\
\text { Ajumako/Eyan/Esiam }\end{array}$ & Mfantiman & 5 \\
\hline Ashanti & Ashanti & Ashanti & $\begin{array}{l}\text { Ofinson } \\
\text { Kumasi Metro }\end{array}$ & Kumasi Metro & 5 \\
\hline Western & Western & Western & $\begin{array}{l}\text { Sekondi Takoradi } \\
\text { Nzima East }\end{array}$ & $\begin{array}{l}\text { Sekondi/Takoradi } \\
\text { Nzima East }\end{array}$ & 6 \\
\hline Northern & Northern & Northern & $\begin{array}{l}\text { Tamale Metro } \\
\text { Yendie }\end{array}$ & $\begin{array}{l}\text { Tamale Metro } \\
\text { Yendie }\end{array}$ & 6 \\
\hline Total & $\mathbf{5}$ & $\mathbf{6}$ & \multicolumn{1}{|c|}{$\mathbf{1 2}$} & $\mathbf{8}$ & $\mathbf{3 1}$ \\
\hline
\end{tabular}

2. Regional, Branch and Local Executives of Women's Committees

\begin{tabular}{|l|c|c|c|c|c|c|}
\hline Region & ICU & GAWU & CBMWU & MDU & GPRTU & Total \\
\hline $\begin{array}{l}\text { Greater } \\
\text { Accra }\end{array}$ & - & Food Research & Highways & - & Kaneshie\# & 3 \\
\hline Eastern & RWC & RWC & - & - & Asamankese\# & 3 \\
\hline Central & RWC & RWC & RWC & - & - & 3 \\
\hline Ashanti & RWC & RWC & - & - & RWC & 3 \\
\hline Western & RWC & RWC & RWC & RWC & - & 4 \\
\hline Northern & RWC & RWC & - & - & - & 2 \\
\hline Total & 5 & 6 & 3 & 1 & 3 & 18 \\
\hline
\end{tabular}

\# Branch 


\section{Branch/Local Executives of Identified National Unions: (ICU, GAWU and GMWU)}

\begin{tabular}{|l|l|l|l|}
\hline Region & ICU & GAWU & GMWU \\
\hline $\begin{array}{l}\text { Greater } \\
\text { Accra }\end{array}$ & $\begin{array}{l}\text { Fan Milk } \\
\text { Melcom } \\
\text { Golden Tulip }\end{array}$ & $\begin{array}{l}\text { Food Research } \\
\text { Institute }\end{array}$ & PMMC \\
\hline Eastern & $\begin{array}{l}\text { Intravenous } \\
\text { KES Hotel }\end{array}$ & $\begin{array}{l}\text { CRIG } \\
\text { VREL }\end{array}$ & GCD Akwatia \\
\hline Central & $\begin{array}{l}\text { Fruits \& Flavour } \\
\text { GRATIS } \\
\text { Elmina Beach Hotel }\end{array}$ & $\begin{array}{l}\text { TOPP } \\
\text { Forestry }\end{array}$ & - \\
\hline Ashanti & $\begin{array}{l}\text { Hotel De Kingsway } \\
\text { Neoplan } \\
\text { Melcom }\end{array}$ & $\begin{array}{l}\text { CSSVD } \\
\text { Ejura Farms }\end{array}$ & $\begin{array}{l}\text { AnglogoldAshanti } \\
\text { (Obuasi) } \\
\text { Newmount Ken- } \\
\text { yase }\end{array}$ \\
\hline Western & $\begin{array}{l}\text { Ahantaman Rrl Bank } \\
\text { TICO } \\
\text { GHUMCO } \\
\text { Busua Beach Resort }\end{array}$ & $\begin{array}{l}\text { SPIL } \\
\text { BOPP }\end{array}$ & $\begin{array}{l}\text { Tarkwa Goldfields } \\
\text { Ghana Manganese } \\
\text { Co }\end{array}$ \\
\hline Northern & $\begin{array}{l}\text { GRATIS } \\
\text { West Mamprusi Rl Bank } \\
\text { Japan Motors } \\
\text { Mole Motel }\end{array}$ & $\begin{array}{l}\text { Kpong Tamale Vet } \\
\text { Ghana Cotton Co }\end{array}$ & \\
\hline Total & 19 & 11 & \multicolumn{1}{|c|}{} \\
\hline
\end{tabular}

\section{Branch/Local Executives of Identified National Unions: (CBMWU, MDU and GPRTU)}

\begin{tabular}{|l|l|l|l|}
\hline Region & CBMWU & MDU & GPRTU \\
\hline $\begin{array}{l}\text { Greater } \\
\text { Accra }\end{array}$ & $\begin{array}{l}\text { Ghana Highways } \\
\text { Advanced Con- } \\
\text { struction }\end{array}$ & GDLC & $\begin{array}{l}\text { Regional Office } \\
\text { Tema Station } \\
\text { Novotel Branch } \\
\text { Kaneshie Office }\end{array}$ \\
\hline Eastern & $\begin{array}{l}\text { Sonitra } \\
\text { Ghana Highways }\end{array}$ & $\begin{array}{l}\text { Volta Lake Transport } \\
\text { Company }\end{array}$ & Koforidua No1 \\
\hline Central & $\begin{array}{l}\text { Ghana Highways } \\
\text { AESL }\end{array}$ & \multicolumn{1}{|c|}{-} & $\begin{array}{l}\text { Swedru } \\
\text { Assin Fosu }\end{array}$ \\
\hline Ashanti & TOPP International & Shippers' Council & $\begin{array}{l}\text { Bekwai } \\
\text { Mampong }\end{array}$ \\
\hline Western & $\begin{array}{l}\text { Ghana Highways } \\
\text { K\&H } \\
\text { Consar }\end{array}$ & $\begin{array}{l}\text { Speedline } \\
\text { GDLC } \\
\text { Hull Blyth }\end{array}$ & Takoradi Main \\
\hline Northern & $\begin{array}{l}\text { K\& A } \\
\text { Ghana Highways }\end{array}$ & \multicolumn{2}{|c|}{6} \\
\hline Total & 12 & $\begin{array}{l}\text { Tamale Aboabo } \\
\text { Walewale }\end{array}$ \\
\hline
\end{tabular}




\section{Executives of Organised Informal Economy Groups}

a. GTUC

i. Madina Traders' Union

ii. Makola Market Traders' Union

b. GAWU

i. Greater Accra Region: Machie Women's Group

ii. Central Region: Asamanse, New Ebu and Old Ebu

iii. Ashanti Region: Nerehebi and Foase,

iv. Western Region: Enuamuasa, Kwamekrom and Camp

v. Northern Region: Sankpala, Kapong and Yipala

vi. Brong Ahafo Region: Kintampo Yam Producers \& Sellers' Association and Nwawasua

vii. Upper West Region: Tono Irrigation Farmers' Association and Dora Women's Group

c. LGWU

i. Global Handicraft Association and

ii. Darkuman Artisans' Association

d. PSWU

i. Ghana Union of Photographers and

ii. National Lotto Receivers' Union

e. TWU

i. Aburi Industrial Centre and

ii. Woodworkers' Association of Ghana-Winneba and Swedru

f. ICU

i. GHATOF,

ii. GHABA (Greater Accra, Eastern, Central, Western, Northern Regions),

iii. BATMAG (Eastern and Central Regions),

iv. GHABBSO,

v. Basket Weavers and Leather Manufacturers

\section{Executives of Selected Splinter National Unions}

a. Ghana Federation of Labour

b. Food and Allied Workers' Union

c. National Union of Harbour Employees

\section{Others}

a. Former Female Local Union Secretary GMWU

b. Officials of the National Labour Commission 


\section{APPENDIX C: RESEARCH PARTICIPANTS-UNION EVENTS COVERED}
a. Founding Conference of the CTUC Africa-Accra
b. GAWU Quadrennial Delegates Conference; Kwadaso
c. GTUC Western Region May Day Parade-Tarkwa
d. GPRTU Ashanti Regional Branch Secretaries' Meeting-Kumasi
e. Regional and District Councils of Labour meetings:
vi. Cape Coast,
vii. Kumasi, and
viii. Sekondi-Takoradi,
f. BOPP Local Union General Meeting
g. Northern Region GHABA Babies Meeting-Tamale
h. UNICOF - inauguration of Women's Commission, Eastern Region 


\section{APPENDIX D:}

NATIONAL UNION AFFILIATES OF THE GTUC

\begin{tabular}{|l|l|}
\hline Abbreviation & \multicolumn{1}{|c|}{ Full Name } \\
\hline CBWU & Construction and Building Workers' Union \\
\hline CWU & Communication Workers Union \\
\hline GAWU & General Agricultural Workers' Union \\
\hline GMWU & Ghana Mineworkers Union \\
\hline GPRTU & Ghana Private Road Transport Union \\
\hline GTPCWU & $\begin{array}{l}\text { General Transport, Petroleum and Chemical Workers' } \\
\text { Union }\end{array}$ \\
\hline HSWU & Health Services Workers Union \\
\hline ICU & Industrial and Commercial Workers' Union \\
\hline LGWU & Local Government Workers' Union \\
\hline MDU & Maritime and Dockworkers' Union \\
\hline NUS & National Union Of Seamen \\
\hline PSWU & Public Service Workers' Union \\
\hline PUWU & Public Utilities Workers' Union \\
\hline REU & Railway Enginemen's Union \\
\hline RWU & Railway Workers' Union \\
\hline TEWU & Teachers' and Educational Workers' Union \\
\hline TWU & Timber and Wood Workers' Union \\
\hline UNICOF & Union of Industry, Commerce and Finance Workers \\
\hline & \\
\hline
\end{tabular}





\section{SUMMARY}

The fall out of globalisation for workers and their movements have been alterations in the nature of work and work relations that undermine trade unions as credible organs for securing workers' rights. Their responses, mainly reactive, have seen unions extend into working terrains that challenge the very principle of their existence. The potential of union response to secure their relevance will depend on their ability to serve the interests of all working people irrespective of their background. Trade union internal democracy derives from the ability of members to utilise their unions in pursuit of their struggles. Union renewal studies acknowledge the importance of internal democracy for union revitalisation, but give scant attention to how union renewal affects internal democracy.

Chapter 1 discusses the present situation of working people and their movements. It also looks at the changing political and economic environment that criminalises unions and poses them as a disincentive to national development by blocking FDI and therefore job creation. As the main trade union centre in Ghana, the GTUC and its national unions have been at the receiving end of economic reforms and the resulting labour market changes. They have instituted a mix of strategies to retain their dominance as workers' representatives. The study explored the impact of selected renewal strategies of the GTUC and its national unions on union internal democracy. The goal of the study raised these specific questions:

i. What are the exact challenges of globalisation facing trade unions in Ghana?

ii. How have the GTUC and its affiliate national unions responded to these challenges?

iii. How have renewal strategies impacted internal union power dynamics?

iv. What are the implications of the emerging power dynamics for sustaining effective union revitalisation?

Globalisation has restructured development and production relations subjecting labour's status and function to fundamental changes.

Chapter 2 discusses the connection between globalisation, labour market reforms and union relevance and legitimacy. This discussion notes the role of the state in legitimising globalisation by mediating national spaces for the successful operations 
of FDI and TNCs to the detriment of workers. In the face of increasing resistance to the social, economic and environmental costs of globalisation, the role of the nation state in ensuring that labour demands do not undermine global capital becomes more crucial. Unions, in order to reverse decline and strengthen their internal structures to withstand the challenges of globalisation, have instituted several strategies. Union renewal studies contend that strategies have a greater chance in reversing union fortunes if they have a wider political orientation and make a link between workplace and broader issues of social justice. They also insist that effectiveness of renewal strategies are contingent on union ideology and therefore its internal dynamism. Revitalisation studies should, however, give attention to how the internal structures of trade unions are impacted by renewal strategies to affect members' access to power tools for defending their workplace rights.

Chapter 3 provides the specific context of the research, its focus and goal. The fluidity of union processes and the lack of procedures to hold them in check to warrant effective accounting of causal factors have led to a reliance on case studies. The flexibility in the selection of cases however imposes elements of bias that can threaten the validity and reliability of findings and restrict the generalisation of research findings. Multiple methods and respondent validation were used to address methodological shortcomings that could have compromised research outcome. The choice of the GTUC, was informed by its visibility and unique role in Ghana's political and economic history. With the exception of the GPRTU, the selected national unions were either predominantly based in the private sector (ICU, CBMWU, GMWU) or had a mix of private and public sector workers as their members (GAWU, MDU). Renewal strategies that the study focused on were those targeting union representation, participation and internal coherence. The GTUC, through these strategies, were attempting to improve representation and participation of its distinct constituents, women, informal economy groups and traditional trade union members. The main body of information was provided through group and individual interviews, document reviews and observations at union events.

Globalisation challenges, Chapter 4 notes, operate in various sites and through a myriad of policies to undermine union effectiveness, relevance and legitimacy. The mix of strategies adopted by the GTUC and its national unions, in order of importance, included expanding and retaining membership by restructuring union shape, structures and processes in addition to enhancing union capacity to deliver its core responsibilities. Strategies targeting external factors included intensified policy engagement at the national level and coalition building with a range of actors. The fourth chapter emphasises the fact that mix of strategies adopted by the GTUC's and its national unions, acknowledges the importance of membership power in union revitalisation. They however, fail to indicate how unions intend to deal with the broader principles underlying the globalised production systems that shape the current terrain in which they operate. 
Chapter 5 observes that the GTUC and its national affiliates have had varied successes organising in the informal economy and continue to grapple with how to incorporate informal economy members into union structures. The discussions pointed out that the organisational approach has implications for the nature of demands informal economy members make on union resources, their confidence, group cohesion, identity and independence. The fact that various unions have begun to address the question of meaningful representation suggests some awareness that true representation for informal economy members is important if unions are to benefit from their membership. It appears that as informal economy membership increases within national unions their ability to impact change in union structures increases as the case of GAWU and ICU show. Separate and independent organisation gives better representation and voice and the experience of the GPRTU as one of the strong national unions that is consistent and focused on work related problems of its members is a clear example. The potential benefit of organising informal economy workers has been submerged by the failure of the GTUC and its national unions to utilise the energies of core workers based in secure formal economy employment, with the non-core temporary workers and informal economy workers at the margins of formal economy. Union shortcoming in organising informal economy workers reflected a weak conceptualisation of the informal economy and its relations with the informalisation of the formal.

Chapter 6 examines the consciousness of women trade union leaders in the GTUC and selected national and the potential of their demands and vision to transform union structures. The GTUC and the national unions use the two-pronged approach of separate organs to improve participation and special representation to address disparity in representation. These strategies have been anchored through constitutional amendments with a supporting policy framework. A major achievement of union gender democracy strategies has been the increased participation of women in trade union decision-making structures. Union education had also created a core group of women ready to take up trade union positions beyond those reserved for women. The weakness of the strategies has been the focus on women and little attempt to improve the operations of the women's committees within union structures. The site of encounter with unions determines the manner in which women frame their demands and the context which shapes the goals they set for addressing such demands. Gender democracy, despite its limitations, was providing the occasion for women to connect with their unions and slowly melting male resistance to female trade union leadership. Though unions were failing to provide women with space for the articulation of their concerns in a consistent and engaging manner, women's awareness of this shortcoming proved an important indication of some level of consciousness. Such awareness formed the basis for the development of power and authority for providing some basis for mobilising to secure redress. The promotional measures have made the strongest impact on trade union women leaders and offer a site for women potential to push for further strategies that will lend 
themselves to a further transformation in gender democracy strategies. Consciousness shapes the acquisition of tools like power, authority and influence to generate additional demands for pursuing more claims.

When union renewal strategies target participatory structures they alter the operational remit of union representative structures as well as their potential to offer members adequate power tools to pursue their interests.

Chapter 7 explores how the DCLs and RCLs of the GTUC provide the necessary conditions for members to utilise their unions for the pursuit of their interests. It notes how membership size, sense of union relevance, networking avenues and connection with the communities made DCLs and RCLs important mobilising and solidarity building points for union action. These avenues therefore served as important power tools that could be marshalled to secure union rights. However the structural location of the DCLs and RCLs as well as the absence of committed resources hamper members' access to and utilisation of significant power tools. The RCLs and DCLs however hold considerable potential as mobilisation and solidarity points for the GTUC and their effective operation should offer the site for real union renewal. This is because of the power tools they hold in the form of membership aggregation, and contact with the communities. The emerging power dynamics is located in the tension between elected union leaders and union staff results from the conceptual confusion of the role of the councils of labour in union governance. Renewal strategies thus have to address the cession of real power and autonomy to these structures.

Chapter 8 examines how the interplay between union functions, role and activities provided sufficient room for a meaningful engagement of locals with their national unions for the pursuit of their interests. The sites and targets of union struggles as revealed through union challenges were government policies and management practices that weakened enterprise survival and therefore union existence. Locals also struggled to make their unions responsive to their needs. Union size and quality, relevance, as well as leadership commitment were important power tools shoring up unions in the workplace. Factors boosting union existence enhanced union positions and served as power tools for engaging union struggles. Membership entitlements were limited to how members can secure direct benefits from their national unions and less in terms of how they can expand their voices in their unions and impact union decision-making on a continuous basis. The conception of membership and the corresponding entitlements however constrained access to power tools.

Chapter 9 the concluding chapter highlights the salient features of union membership in the three locations of gender, informal economy and membership holding structures at the regional, district and local level. It was possible to distil the various forms, sites and content of union struggles by framing union internal democracy as 
membership access to union structures and processes. Such access serves as power tools for members to engage their concerns. Unions were providing their members the potential to enhance group coherence and solidarity. Resource constraints and an absence of constitutional autonomy limited access to union power tools such as group coherence, sense of solidarity and mobilisation potential. The most important power tool however was located in union membership. This found expression in the strong belief in the trade unions as the most important organ for confronting the challenges of globalisation. Notions of union membership and the manner in which unions granted membership entitlements constrained access to union resources. In all locations union members access to resources were not being expanded by renewal strategies. However, union renewal strategies were drawing attention to the various forms of constraints. The attention still remains on how members in the various locations can gain access. This generates forms of inter group tensions with formal economy male members in the locals reluctant to ceded space to female and informal economy members.

The ability of revitalisation strategies to strengthen unions as they confront the challenges of globalisation can only be realised in how unions deal with the various barriers that its diverse members face in accessing union power tools. Effectively dealing with access must be located in strategies that seek to transform internal sites of contestations within union structures and processes into solidarity and mobilisation points. 



\section{SAMENVATTING}

De gevolgen van mondialisering voor werknemers en hun bewegingen hebben geleid tot veranderingen in het karakter van hun werk en werkverhoudingen, waardoor vakbonden, als geloofwaardige instellingen voor het waarborgen van werknemersrechten, zijn ondermijnd. Het antwoord van vakbonden op deze veranderingen was vooral reactief met een uitbreiding van hun werkterrein op zodanige wijze, dat ze daarmee hun eigen bestaansrecht aantasten. Het potentieel voor vakbonden om hun relevantie te behouden zal afhangen van hun vermogen om de belangen van alle werkende mensen te vertegenwoordigen ongeacht hun achtergrond. De interne democratie van vakbonden vormt een belangrijk onderdeel hierbij, omdat het afgeleid wordt van de mogelijkheid van leden om de vakbonden te gebruiken bij het nastreven van hun doeleinden. Jaren van economische hervormingen in Ghana hebben het voortbestaan van vakbonden onder druk gezet op het punt van ledenaantallen en het vermogen werknemersbelangen te verdedigen.

Hoofdstuk 1 bespreekt de huidige situatie van werkende mensen en hun organisaties. Ook kijkt het naar het veranderende politieke en economische milieu waardoor vakbonden criminaliseren en daardoor een belemmering vormen voor buitenlandse investeringen en zodoende voor het creëren van arbeidsplaatsen. De voornaamste vakbondscentrale in Ghana, de Ghana Trade Union Congress (GTUC), en de daarbij aangesloten nationale vakbonden hebben de klappen gekregen van economische hervorming en de daaruit voortvloeiende veranderingen op de arbeidsmarkt. Ze hebben een mix van strategieën opgezet om hun positie als vertegenwoordigers van werknemers te behouden. Dit onderzoek heeft de effecten van specifieke vernieuwingstrategieën van de GTUC en de aangesloten nationale vakbonden bestudeerd op het gebied van interne vakbondsdemocratie. Het doel van het onderzoek heeft de volgende specifieke vragen opgeroepen:

i. Wat zijn de exacte uitdagingen voor vakbonden in Ghana als gevolg van mondialisering?

ii. Hoe hebben de GTUC en de aangesloten nationale vakbonden gereageerd op de uitdagingen?

iii. Hoe hebben vernieuwingstrategieën de interne machtsverhoudingen van vakbonden beïnvloed?

iv. Wat zijn de gevolgen van de gebleken machtsdynamieken voor het ondersteunen van effectieve revitalisatie van vakbonden? 
Mondialisering heeft ontwikkelings- en productieverhoudingen op een fundamentele wijze geherstructureerd met gevolgen voor de status en functie van werk.

Hoofdstuk 2 bespreekt de samenhang tussen mondialisering, arbeidsmarkthervormingen en de relevantie en de rechtmatigheid van vakbonden. Deze discussie schenkt aandacht aan de rol van de overheid bij het legitimeren van mondialisering, door economische en politieke besluitvormingsfora beschikbaar te stellen voor succesvolle ondernemingen van Buitenlandse Directe Investeringen (FDI) en multinationals, met nadelige gevolgen voor de werknemers. Ondanks toenemende tegenstand door vakbonden en burgergroepen tegen de sociale, economische en milieukosten van mondialisering, wordt de rol van de staat steeds belangrijker in het voorkomen dat werknemerseisen het internationale kapitaal afschrikken. Vakbonden hebben verschillende strategieën opgezet om het verval terug te draaien en hun interne structuren te versterken om de uitdagingen van mondialisering te weerstaan. Onderzoek naar deze strategieën stelt, dat ze grotere kans van slagen hebben om de tegenspoed van de vakbonden terug te draaien als ze een bredere politieke oriëntatie hebben en als ze een verband leggen tussen de werkplek en ruimere kwesties van sociale rechtvaardigheid. Deze onderzoeken dringen er ook op aan dat de effectiviteit van vernieuwingsstrategieën afhangt van de ideologie van de vakbonden en daardoor van hun interne dynamiek. Onderzoek naar vernieuwing van vakbonden zou echter meer aandacht moeten geven aan hoe de interne structuur van vakbonden de toegang van werknemers regelt tot machtsinstrumenten voor het verdedigen van hun rechten.

Hoofdstuk 3 geeft de specifieke context van het onderzoek weer, met zijn focus en doel. De veranderlijkheid van vakbondsprocessen en het ontbreken van procedures om daarmee om te gaan zodat causale factoren effectief beschouwd konden worden, hebben ertoe geleid dat dit onderzoek berust op de bestudering van casussen. De flexibiliteit in de selectie van casussen brengt echter elementen van vooringenomenheid met zich mee, die de geldigheid en betrouwbaarheid van de resultaten kunnen bedreigen en de generalisatie van de onderzoeksresultaten beperken. Meerdere methodes en validatie van respondenten zijn gebruikt om methodologische tekortkomingen aan te pakken die de onderzoeksuitkomsten hadden kunnen compromitteren. De keuze voor de GTUC was ingegeven door haar grote zichtbaarheid en unieke rol in Ghana's politieke en economische geschiedenis. Met uitzondering van de GPRTU zijn de geselecteerde nationale vakbonden met name vertegenwoordigers voor de werknemers in de private sector (ICU, CBMWU, GMWU), ofwel hebben ze een mix van leden in de private en publieke sector (GAWU, MDU). Het onderzoek richt zich op vernieuwingsstrategieën van de GTUC, die ingaan op de vertegenwoordiging, participatie en interne coherentie van vakbonden. De GTUC probeerde met deze strategieën om de vertegenwoordiging en participatie van specifieke leden te verbeteren, zoals van vrouwen, de informele economie en traditionele vakbondsleden. Het gros van de gegevens is verzameld via 
groeps- en individuele interviews, bestudering van documenten en waarneming tijdens vakbondsbijeenkomsten.

Uitdagingen van mondialisering, zo stelt hoofdstuk 4, werken door op verschillende plekken en via een groot aantal beleidsstukken en ondermijnen de effectiviteit, de relevantie en de legitimiteit van vakbonden. De strategieën die aangenomen zijn door de GTUC en haar aangesloten nationale vakbonden waren, in afnemende belangrijkheid, uitbreiding en behoud van leden door het herstructureren van de vorm, de structuur en de processen van vakbonden, naast het vergroten van de capaciteit van vakbonden om hun kernverantwoordelijkheden te kunnen waarborgen. Andere strategieën waren toegenomen deelname aan de politiek op nationaal niveau en het smeden van coalities met een reeks van actoren. Dit hoofdstuk legt nadruk op het feit dat de mix van strategieën die aangenomen zijn door GTUC en haar nationale vakbonden het belang van de macht van leden in het hernieuwen van de vakbonden erkennen. Het hoofdstuk besluit door te wijzen op het onvermogen van vakbonden om aan te geven hoe ze van plan zijn om te gaan met de bredere principes die de basis zijn van het mondiale productiesysteem, dat vorm geeft aan hun huidige werkterrein.

Hoofdstuk 5 stelt dat de GTUC en haar nationale partners wisselend succes hebben gehad om de informele economie te organiseren en dat ze blijven worstelen met hoe werknemers uit de informele economie geïntegreerd kunnen worden in vakbondsstructuren. De discussies gaven aan dat de organisatorische aanpak gevolgen heeft voor het soort aanspraak dat leden van de informele economie kunnen doen op vakbondsmiddelen. De organisatorische aanpak heeft ook invloed gehad op het vertrouwen, de samenhang van de groep, de identiteit en de onafhankelijkheid van vakbondsleden vanuit de informele economie. Het feit dat verschillende vakbonden de vraag van zinvolle vertegenwoordiging aan de orde stellen, geeft aan dat er enig besef is dat echte vertegenwoordiging van leden uit de informele economie belangrijk is, als de vakbonden baat willen vinden bij hun lidmaatschap. Het lijkt erop dat, als er een toename is van leden vanuit de informele economie bij nationale vakbonden, de mogelijkheden van deze leden om de vakbondsstructuren te veranderen toenemen, zoals het voorbeeld van GAWU en ICU laten zien. Aparte en onafhankelijke organisatie levert betere vertegenwoordiging en participatie van vakbondsleden uit de informele economie. De ervaring van de GPRTU, één van de sterke nationale vakbonden, die consistent gericht is op de werkgerelateerde problemen van haar leden uit de informele economie, is een duidelijk voorbeeld van de kracht van gescheiden organisatie. Tekortkomingen van vakbonden in het organiseren van werknemers uit de informele economie geven een zwak begrip weer van de samenhang tussen de informele economie en het proces waardoor de formele economie geïnformaliseerd werd.

Hoofdstuk 6 laat het belangrijkste resultaat van vakbondsstrategieën voor gender democratie zien, namelijk de toename van deelname van vrouwen in besluitvor- 
mingsstructuren. Door vakbondseducatie is een kerngroep van vrouwen ontstaan, die klaar is om vakbondsposities buiten de specifiek gereserveerde posities voor vrouwen op zich te nemen. Het zwakke punt van de strategieën is de focus slechts op vrouwen, en de geringe poging om de activiteiten van vrouwencomités in vakbonden te ontwikkelen. De positie die vrouwen innemen in hun vakbond bepaalt hoe ze hun eisen vorm kunnen geven evenals hoe ze doelen stellen om hun eisen te benaderen. Ondanks beperkingen gaf gender democratie vrouwen de mogelijkheid om met hun vakbonden in contact te komen en de mannelijke tegenstand tegen het lidmaatschap van vrouwen langzaam te laten verdwijnen. Ook al waren vakbonden niet in staat om vrouwen ruimte te geven om hun belangen uit te spreken op een consistente en aansprekende manier, toch gaven vrouwen aan een zeker besef te hebben van deze tekortkoming. Dit besef is de basis geweest voor de ontwikkeling van macht en autoriteit om de patriarchale structuur van vakbonden te transformeren. Dit heeft vrouwelijke leiders geholpen om toegang te krijgen tot machtsmiddelen zoals autoriteit en invloed om aanvullende eisen te stellen.

Indien de vernieuwingstrategieën van vakbonden zich richten op verandering van de participatieve structuren (zoals lokale vakbonden, Councils of Labour) die een manier bieden waardoor leden deel kunnen nemen in vakbondsbesluitvorming, verandert daardoor ook de operationele verantwoordelijkheid van de vakbonden met betrekking tot de groepen die ze vertegenwoordigen en de belangen die ze nastreven. Ook verandert het potentieel van de participatieve structuren om de leden toegang te bieden tot machtsmiddelen. Hoofdstuk 7 onderzoekt hoe de 'Councils of Labour', de RCL en DCL van de GTUC, de voorwaarden hebben geschapen die vakbondsleden nodig hadden om hun vakbonden te kunnen gebruiken bij het nastreven van hun belangen. De hoeveelheid leden in deze groepen, het gevoel van relevantie van de vakbond, netwerkmogelijkheden en aansluiting met de gemeenschap, maakten de Councils of Labour tot belangrijke structuren om solidariteit en mobilisatie voor vakbondsacties te creëren. Deze structuren dienden daardoor als belangrijke machtsmiddelen om vakbondsrechten te verkrijgen. Echter, de locatie van de DCL en RCL in de vakbondsstructuur, evenals de afwezigheid van toegewezen middelen belemmerden voor leden de toegang tot, en het gebruik van, deze belangrijke machtsmiddelen. De RCLs en DCLs hebben echter een aanzienlijk potentieel voor mobilisatie en solidariteit van leden en hun effectieve positionering zou de plek kunnen zijn voor echte vernieuwing van de vakbonden. Dit komt door de machtsmiddelen die ze bezitten in de vorm van lidmaatschapsaggregatie en hun contact met de bevolking. De ontstane machtsdynamiek, veroorzaakt door de spanning tussen gekozen vakbondsleiders en vakbondsmedewerkers, komt door de conceptuele verwarring van de rol van Councils of Labour in het vakbondsbestuur. Vernieuwingstrategieën moeten daarom de overdracht van echte macht en autonomie aan deze participatieve structuren sturen.

Hoofdstuk 8 bestudeert hoe de interactie tussen de functies, de rol en de activiteiten van vakbonden voldoende ruimte hebben gegeven voor een zinvolle interactie van 
lokale vakbonden met hun nationale vakbonden voor het vertegenwoordigen van hun belangen. De vakbonden worstelden met overheidsbeleid en management, die het potentieel hadden om het voortbestaan van bedrijven te bedreigen. Het overleven van bedrijven is belangrijk voor het bestaan van vakbonden. Lokale vakbonden worstelden ook om de overkoepelende vakbonden ontvankelijk te maken voor hun behoeften. De grootte, kwaliteit, relevantie en de betrokkenheid van de lokale vakbond waren belangrijke factoren die hen steunden bij het verdedigen van werknemersbelangen op de werkplek. Deze factoren verbeterden de positie van de vakbonden en dienden als machtsmiddelen voor het aangaan van vakbondsstrijd. De rechten verbonden aan het vakbondslidmaatschap waren beperkt tot hoe leden directe voordelen kunnen krijgen van hun nationale vakbonden, en in mindere mate hoe ze hun stem kunnen vergroten in hun vakbond en invloed kunnen hebben in vakbondsbesluitvorming op een regelmatige basis. De manier waarop de vakbonden het lidmaatschap conceptualiseerden en waarop ze de bijbehorende rechten voor leden vormgaven, beperkte echter de toegang van leden tot de machtsmiddelen.

Hoofdstuk 9 is het concluderende hoofdstuk dat de meest opvallende kenmerken van vakbondslidmaatschap naar voren haalt op het gebied van gender democratie, de informele economie en lidmaatschapsstructuren op regionaal, district en lokaal niveau. Door de interne vakbondsdemocratie op te vatten als de toegang van leden tot vakbondsstructuren en processen, was het mogelijk de verschillende vormen, locaties en inhoud van vakbondsstrijd af te leiden. Die toegang fungeert namelijk als een machtsmiddel voor leden om hun belangen te kunnen verdedigen. Vakbonden gaven hun leden de mogelijkheid om coherentie en solidariteit van de groep te vergroten. Druk op middelen binnen de vakbonden en afwezigheid van constitutionele autonomie beperkten echter toegang tot vakbondsmachtsmiddelen zoals groepscoherentie, een gevoel van solidariteit en potentieel tot mobiliseren. Het belangrijkste huidige machtsmiddel bleek het lidmaatschap van een vakbond te zijn. Dit kwam tot uiting in het sterke geloof van vakbondsleden in de vakbond als het meest belangrijke orgaan om de uitdagingen van mondialisering het hoofd te bieden. Het ontstaan van vakbondslidmaatschap en de manier waarop vakbonden lidmaatschapsrechten toekenden, beperkte de toegang van leden tot vakbondsmiddelen. In alle locaties werd de toegang van vakbondsleden tot middelen niet vergroot door vernieuwingstrategieën. Echter, vakbondsvernieuwingstrategieën vestigden de aandacht van de vakbonden op de verschillende soorten beperkingen. Momenteel is de focus vooral gericht op hoe leden op de verschillende locaties toegang tot vakbondsbesluitvorming kunnen krijgen. Hierdoor ontstaat spanning tussen groepen waarbij mannelijke leden uit de formele economie in de lokale vakbonden terughoudend zijn om te plaats te maken voor vrouwelijke leden en leden vanuit de informele economie.

Het vermogen van vernieuwingstrategieën om vakbonden te versterken om de uitdagingen van mondialisering aan te gaan, kan slechts gerealiseerd worden door 
de manier waarop vakbonden omgaan met de verschillende obstakels die hun verschillende leden tegenkomen bij de toegang tot vakbondsmachtsmiddelen. De strategieën moeten ruimte bieden voor het effectief leveren van toegang tot besluitvorming en machtsmiddelen voor alle leden. Ze moeten erop gericht zijn om interne frictie in vakbondsstructuren en -processen te transformeren tot solidariteit voor een gezamenlijke zaak. 


\section{ACKNOWLEDGEMENTS}

The process of producing this thesis has been long, and a shared experience involving several people and events in varied locations. A number of people have shaped the circumstances in which this thesis was produced directly through contributions of ideas and suggestions. Others less directly by providing opportunity and facilitating the environment for its successful completion. But I dare say that each contribution, whatever its size or location, has been invaluable in this long arduous journey that is ending thus. Still, I single out for mention a few individuals, and that will not be a comment on the quality of contribution of those whose names do not appear in the lines that follow.

I am deeply grateful to my two promoters, Professors Pim Martens of ICIS, Maastricht University, and Kwame Ninsin, Institute for Democratic Governance, Ghana, for launching and guiding me through the production this thesis. Their contribution went beyond thesis production to open new vistas in the scientific community in the field of labour and trade union research.

Funding for an enterprise such as this is crucial, always. My gratitude goes to the management of the Ghana NUFFIC team, the 'MA Programme in Governance and Sustainable Development' project for their nomination that made it possible for me to access the PhD NUFFIC grant that stayed available throughout. This project, forms part of The Netherlands Programme for the Institutional Strengthening of Post-Secondary Education and Training Capacity (NPT) designed as a collaborative effort between the Institute for Development Studies, University of Cape Coast, Ghana and the University of Maastricht, the Netherlands. Institutional support from IDS in particular and UCC in general has been immense beyond access to the generous grant. It has included the space to concentrate on my research devoid of teaching and other responsibilities and unlimited access to office equipment and transportation. A special thank you to the present Director, Prof J Victor Mensah for his readiness to make IDS resources available to me without reservation; and to Dr Francis Enu-Kwesi who was always available to respond to my numerous queries about the NUFFIC Ghana project.

Others directly connected to shaping the content of this thesis at the intellectual level, include Edward Webster, the Ela Bhatt Professor of Development and Decent Work at the International Centre for Development and Decent Work (ICDD), Uni- 
versity of Kassel. My stint as Guest Lecturer from October to December, 2009 at ICDD gave me the opportunity to benefit from his insights on labour in development generally but more specifically the informal economy labour force and its relations with trade unions. I will like to mention his generous offer of publications that helped to improve the analytical discourse in chapter five. Sue Ledwith of Ruskin College in the UK was generous to give feedback to Chapter Six of this thesis and in addition to offer literature that enriched the debate on gender democracy. In a similar manner, Jon Kraus of the State University of New York, suggested list of literature sources and offered publications which gave a fresh lease to the entire area of trade union history in West Africa and Ghana. Gerard Kester, formerly of ISS, the Hague, though mentioned last was the first intellectual stimulator for my interest in trade union research. His coordination of APADEP which was instrumental in linking African research institutions like IDS with trade union education and research provided me the rare opportunity to be involved in university-based research that was directly connected to policy and development challenges in a meaningful way.

Information is the foundation on which thesis production rests. How it is gathered, identification of sources and how they are accessed and meaning drawn out are important parts of any research, not least for a Ph.D. thesis. These processes depended on several people who have been invaluable in easing the trip. Space does not allow to mention all. I will like to mention just a fraction. First is at the GTUC national headquarters the Hall of Trade Unions in Accra, the then Secretary-General Kwasi Adu-Amanakwa who gave permission for this research. Kwasi deserves special mention for introducing me to trade union research, through APADEP. Others at the Hall including, David Dorkenoo, Yaw Baah and Alberta Laryea-Djan facilitated my entry to the national unions. The team of research assistants who led me to research participants and assisted with interviews, transcribing taped interviews, typing interview notes, editing and coding include, Harriet Botchey, Robert Asekabta, Dorcas Amuquandoh, Francisca Bortei, Ahmed Adamu, J C FrimpongManso, Mariama Sumani, Samuel Doughan, Mary Fortune Asiam and Anthony Nyane. The research participants from the shop floor to the farm lands, market place and street corners who graciously opened up their inner most experiences and concerns deserve special mention. Without their inputs so generously offered this thesis would not have been possible.

Thesis production imposes demands on one's time and social life. Friends and colleagues help to spice it up and reduce the strain of this exacting intellectual exercise. I have been fortunate, in peer support and administrative facilitation from three locations. The first is at UCC, my home base at IDS: three colleagues, Nana Amma Anokye, Angela Arkosu and Joseph Boateng-Agyenim, fellow travellers in this Ph.D. production journey who gave collegial support and intellectual stimulation, allowing for bouncing back issues of structure and procedure. Nana Amma and Angie, ours has been a journey of numerous challenges. Your rare sense of humour, 
understanding, ear-readiness always, unconditional were the cushions that smoothed the bumpy ride. As we all bring this chapter in our professional lives to a close, I look forward to other occasions for collaborative work.

In my second home at ICIS, Maastricht University, Ph.D. peers were more than intellectual support that spiced up my stay in Maastricht; Annemarie, Jeanine, Maud, Pieter and Monika, Carijn, Alvaro, Astrid, Marc, Moshin and Machiele. Anja and Annet, I am grateful to the environment you provided at ICIS helping me sort out all the numerous administrative demands that eased out my stay. Annemarie, how will I ever forget so much dedication in producing the Dutch translation of the thesis summary. Mike Robertson, Babet Hoeberigs and Hennie Sijen of Mundo a special thank you to the personal touch you gave the programme. Your organisation of my study visits to Maastricht turned a purely administrative relationship into a lasting friendship. My third space has been the ICDD of the University of Kassel, Germany, especially the Ph.D. Kolleg of the "Global Social Policies and Governance Group" of the Department of Globalisation and Politics. I mention first Fruake Bannes for leading me to the group, her comments on chapter five, the variety of invaluable literature offered in both hard and soft copies, and more especially, the soothing teas that calmed my nerves at those times when the body and mind refused to respect the pressures of time. Donna, Anna, Helen and Thomas, also members of the Kolleg, you were remarkable in opening up your discussion space to share your work and listen to mine as well, in the seminar rooms, pubs and restaurants. Our numerous discussions on labour, trade unions and the feminist movement have been invaluable in helping tease out meaning in this thesis. I am also grateful to Christoph Scherr, of ICDD, University of Kassel for the offer of Guest Lectureship that brought me in touch with an unusual concentration of academics who had a critical engagement with trade unions and labour research from stimulating perspectives.

My family deserve mention, having borne my numberless absences and lost contact even during the all too brief periods of presence. Benefitting from their academic engagements eases my guilt burden of neglect. They have made direct contributions to the production of thesis, Seryda Britwum my daughter, transformed my list of references from a word file into the reference format so I could insert literature sources directly into the manuscript with ease. Thank you my dear. Akyana Britwum my son, was my computer advisor. It is thanks to him that my computing skills have so improved. He insisted that the computer was more than an enhanced typewriter and an instrument easy to command. He was always on hand to help resolve both software and hardware failures that are inevitable in the thesis production process. Atta Britwum, my husband, served as my manuscript editor operating with such slim time limits and carrying full responsibility for my failure to meet deadlines irrespective of my inability to keep to dates and timelines. But more importantly he shared in the ideas and acted as a bouncing pad for me to test some of 
my ideas in their most unformed state. We travelled this process together as family and I look forward to more relaxed times together.

Thesis production does not end, I am told. For me it was a passage that opened up numerous avenues. I am set to explore further. 


\section{LIST OF ABBREVIATIONS}

\begin{tabular}{|c|c|}
\hline AU & African Union \\
\hline CBA & Collective Bargaining Agreements \\
\hline CBMWU & Construction and Building Materials Workers' Union \\
\hline CSA & Civil Servants Association \\
\hline CWU & Communication Workers' Union \\
\hline EU & European Union \\
\hline ECOWAS & Economic Community of West African States \\
\hline ESB & End of Service Benefits \\
\hline GAWU & General Agricultural Workers' Union \\
\hline GDLC & Ghana Dock Labour Company \\
\hline GFL & Ghana Federation of Labour \\
\hline GOG & Government of Ghana \\
\hline GMWU & Ghana Mineworkers' Union \\
\hline GSMU & Global Social Movement Unionism \\
\hline GNAT & Ghana National Association of Teachers \\
\hline GPRSP I & Ghana Poverty Reduction Strategy Paper I \\
\hline GPRSP II & Growth and Poverty Reduction Paper II \\
\hline GPRTU & Ghana Private Road Transport Union \\
\hline GTPCWU & Ghana Transport, Petroleum and Chemical Workers' Union \\
\hline GUSS & Ghana Universal Salary Structure \\
\hline HIPC & Highly Indebted Poor Country Initiative \\
\hline HSWU & Health Services Workers' Union \\
\hline ICU & Industrial and Commercial Workers' Union \\
\hline ICFTU/AFRO & $\begin{array}{l}\text { International Confederation of Free Trade Unions-Africa Regional } \\
\text { Organisation }\end{array}$ \\
\hline IFPAAW & $\begin{array}{l}\text { International Federation of Plantation, Agricultural and Allied } \\
\text { Workers }\end{array}$ \\
\hline IILS & International Institute for Labour Studies \\
\hline ILO & International Labour Organisation \\
\hline IMF & International Monetary Fund \\
\hline IPE & International Political Economy \\
\hline IRO & Industrial Relations Officer \\
\hline ISODEC & Integrated Social Development \\
\hline ITO & International Trade Organisation \\
\hline ITS & International Trade Secretariat \\
\hline
\end{tabular}




$\begin{array}{ll}\text { LGWU } & \text { Local Government Workers' Union } \\ \text { MDGs } & \text { Millennium Development Goals } \\ \text { MDU } & \text { Maritime and Dockworkers' Union } \\ \text { MMDAs } & \text { Metropolitan, Municipal, and District Assemblies } \\ \text { MNCs } & \text { Multinational Corporations } \\ \text { NEC } & \text { National Executive Committees } \\ \text { NLC } & \text { Nigerian Labour Congress } \\ \text { NUS } & \text { National Union of Seamen } \\ \text { PMSU } & \text { Professional and Managerial Staff Union } \\ \text { PSMRP } & \text { Public Sector Management Reform Programme } \\ \text { PSWU } & \text { Public Services Workers' Union } \\ \text { PUWU } & \text { Public Utilities Workers' Union } \\ \text { QDC } & \text { Quadrennial Delegates' Congress (GTUC) } \\ \text { SASE } & \text { Quadrennial Delegates' Conference (National Unions) } \\ \text { SAP } & \text { Selected Accelerated Salary Enhancement } \\ \text { SMU } & \text { Structural Adjustment Programme } \\ \text { SIGTUR } & \text { Social Movement Union } \\ \text { SOE } & \text { Southern Initiative on Globalisation and Trade Union Rights } \\ \text { TGLEU } & \text { State Owned Enterprises } \\ \text { TEWU } & \text { Textile, Garment and Leather Employees' Union } \\ \text { TNCs } & \text { Teachers and Educational Workers' Union } \\ \text { TWU } & \text { Transnational Corporations } \\ \text { WTO } & \text { Timber and Woodworkers' Union } \\ & \text { World Trade Organisation }\end{array}$




\section{CURRICULUM VITAE}

Akua Opokua Britwum was born in January 9, 1957 in Koforidua, Ghana. She obtained her General School Certificate Ordinary and Advanced Levels in 1975 and 1977 as a student of Aburi Girls' Secondary School in Ghana. Thereafter, she graduated with a bachelor degree in Sociology, from the University of Ghana, Legon, in 1980. In 1985 she read for a Postgraduate Certificate in Education from the University of Cape Coast and in 1993 obtained an MPhil in Home Science from the University of Ghana, Legon. She taught at the OLA Training College, Cape Coast from 1985 to 1996, preparing teacher trainees to teach Home Science in Primary and Junior Secondary Schools in Ghana. She joined the Institute for Development Studies in July, 1996 as a Junior Research Fellow. She was promoted to the position of Research Fellow in 1998. In 2008, she earned promotion to the position of a Senior Research Fellow. At the Institute for Development Studies (IDS), she worked on the African Workers' Development Programme (APADEP) first as a researcher and later as the Education Coordinator in charge of the African Wide trade union university based post-graduate certificate programme. In October 4 to 17, 2002, Akua was a guest of the CUSO African Speakers' Tour in the Atlantic Province of Canada. She toured universities and secondary schools, meeting with trade unionists and women's groups delivering lectures on the New Partnership for Africa's Development (NEPAD) and its implications for Ghanaians. From October to December, 2009, she was also a guest Lecturer at the International Centre for Development and Decent Work (ICDD), University of Kassel, Germany teaching the course 'Gender in Economic Decision Making' to Masters Degree students. Her area of teaching and research at the University of Cape Coast's IDS is gender and labour studies. Her publications cover gender based violence, gender and informal economy trade union participation and representation. She is currently the coordinator of the UCC Gender Centre. She is also, the Convenor of the women's advocacy organisation, the Network for Women's Rights (NETRIGHT) in Ghana. 